\title{
The Europeanization of French, German and British China Policies: The case of the arms embargo on China
}

\author{
Vivien L. Exartier \\ West Virginia University
}

Follow this and additional works at: https://researchrepository.wvu.edu/etd

\section{Recommended Citation}

Exartier, Vivien L., "The Europeanization of French, German and British China Policies: The case of the arms embargo on China" (2010). Graduate Theses, Dissertations, and Problem Reports. 4586.

https://researchrepository.wvu.edu/etd/4586

This Dissertation is protected by copyright and/or related rights. It has been brought to you by the The Research Repository @ WVU with permission from the rights-holder(s). You are free to use this Dissertation in any way that is permitted by the copyright and related rights legislation that applies to your use. For other uses you must obtain permission from the rights-holder(s) directly, unless additional rights are indicated by a Creative Commons license in the record and/ or on the work itself. This Dissertation has been accepted for inclusion in WVU Graduate Theses, Dissertations, and Problem Reports collection by an authorized administrator of The Research Repository @ WVU.

For more information, please contact researchrepository@mail.wvu.edu. 
The Europeanization of French, German and British China Policies: The case of the arms embargo on China

\author{
by \\ Vivien L. Exartier \\ एسmس"m issertation submitted to the Eberly College of Arts and Sciences \\ at West Virginia University \\ in partial fulfillment of the requirements \\ for the degree of \\ Doctor in Philosophy \\ in \\ Political Science
}

Approved by

Donley T. Studlar, Ph.D., Chair

Cynthia Chalupa, Ph.D.

Scott Crichlow, Ph.D.

Bob Duval, Ph.D.

John Kilwein, Ph.D.

Department of Political Science

Morgantown, West Virginia

2010

Keywords: embargo, EU, China

Copyright 2010 Vivien L. Exartier 


\title{
ABSTRACT \\ The Europeanization of French, German and British China Policies: The case of the arms embargo on China
}

\author{
by Vivien L. Exartier
}

This study analyzes the impact of France, Britain and Germany on European Union sanction policy on China. The study argues that Britain, France and Germany affect the EU sanction policy on China through bottom-up and horizontal Europeanization due to their historic and strategic ties to the PRC and their predominance in the armament industry. The study specifically reviews the case of the handling of the lift of the arms embargo between 2003 and 2005, imposed on the wake of the Tiananmen Square Massacre in 1989. The methodology combines a questionnaire, addressed to defense and foreign affairs officials from the three member states and EU officials, press articles, interviews and speeches and applies three theories about responses to Europeanization. The study found that The Big Three influence the agenda-setting and policy formulation by uploading their policy preferences but cannot implement those policies if they conflict with US interests. 


\section{AKNOWLEDGEMENTS}

Dr. Donley Studlar, my chair and mentor, an outstanding faculty who has been very supportive over the years, helped me to think better, gave me the opportunity to teach and who seems like a true Europhile!

The Committee members who have all been my professors and that taught me so much: I thank them for their feedback, patience, help on the methodology, and support.

The Department of Political Science, Dr. Joe Hagan and Dr. Alan Hammock, chairs during my time in the program. All the faculty, remarkable scholars: a great sense of pedagogy and a true passion in their field.

Dr. Jeff Worsham for challenging me, for teaching me tough lessons about graduate school and for giving me great ideas for my methods section!

The Eberly College of Arts and Sciences and Dean King for their support on conference and research trips.

The respondents of my questionnaire and folks who helped me in my interviewing and research requests.

Todd McFadden who helped me when I was in need.

My colleagues in Political Science Department: Kyle Christensen, Theresa Hutchins, Mark Lehman, Hadii Mamudu, Noelle N’Diaye, Matt Sutton, Brent Eastwood, David Plazek, Valerie Danley, Viviane Foyou, Arnita Sitasari, Fredric Appah, Fabio Francchi, Arian Spahiu for interesting chats, long nights sweating over statistics, conference trips, bits of advice and good laughs!

LeeAnn Greathouse, Ronny Thompson, Beckie Digman from the Department of Political Science whom I always asked so many impossible things and who always helped me... My colleagues in Student Affairs so enthuse about our school and our students: Dr. Tom Sloane, Dr. David Stewart, James Johnson, Debbi Pariser, Ayumi Tsuda, the late Cecilia Rollins.

The Oklahoma State Faculty: Dr. Bob Darcy a true inspiration who recommended the doctoral program at West Virginia University. Dr. Joel Jenswold who was so supportive during my thesis work while I was in Morgantown, Dr. Nixon, a great professor, Dr. Lewis, another europhile.

My Oklahoma State 'crew': Amanda Howard now Dr. Howard, who shared the Ph.D. conquest struggle, my old friend Ismail who convinced me to switch from Business to Political Science, Amanda Hill, Jessica Henson, Dr. David Chatelet, Larisa Yun now in a Ph.D. program at Oklahoma University. 
My colleagues at the Washington Workshops Foundation: Aaron, Sherrie, Leo, Tom, Samie, Tony, supportive and truly dedicated to civic education.

My WVU partners and fiends from the French Department...and from France: Vanessa, now a Ph.D. candidate and Amandine, a French teacher: laughter, horror movies and Panera, and support.

My old high school friend Dr. Guillaume Raux for his words of encouragement and pearls of wisdom.

My dear friend Annabelle, WVU alumna, who has always been here for me in the ups and downs of life.

My pal Thomas Fontaine, White Hall computer lab mate and travel companion, WVU alum, always supportive whether he was in Argentina or Shanghai.

My friends back home who would always cheer me up no matter what and who found the time to visit with me in the US: Emmanuel, Olivier, Sebastien.

My beloved Mwai for her guidance, support, love, sacrifices and...proofreading! My family: my brother Sylvain, Lucile, Bérénice and Robin.

My dear parents whom I owe so much for all their sacrifices and support throughout the years. They always have been here for me, always attentive, helpful and encouraging.

Finally, this wonderful WVU and Morgantown community who always made me feel welcome and gave me countless opportunities. 


\section{CONTENTS}

Chapter 1: Introduction 1

1.0 Introduction 1

1.1 Research Problem $\quad 4$

1.2 Timeline and background information about the arms embargo issue $\quad 9$

1.3 The US interference in the debate 14

1.3 Significance to the Literature and Chapters Overview 15

$\begin{array}{ll}\text { Chapter 2: Definition of Concepts } & 17\end{array}$

2.0 Introduction 17

2.1 Formulation and conduct of foreign policy in the European Union 17

2.1.1 Short History of the Common Foreign and Security Policy 17

2.1.2 Role and attributes of the EU institutions in the CFSP 22

2.2 Sanctions $\quad 32$

2.2 Security 46

2.3 Europeanization $\quad 54$

2.4 Policy Convergence 63

2.5 Adaptation and policy misfits $\quad 67$

2.6 Methodology $\quad 71$

2.6.1 Introduction 71

2.6.2 The Questionnaire and the Interviews 71

2.6.3 Press and journal articles, media interviews and speeches 73

2.6.4 Tweaking three theories to apply to our study $\quad 74$

$\begin{array}{ll}2.6 .5 \text { Expected findings } & 77\end{array}$

$\begin{array}{ll}\text { Chapter 3: The influence of France } & 79\end{array}$

$\begin{array}{ll}3.0 \text { Introduction } & 79\end{array}$

3.1 France’s relations with China 80

3.2 Track record of Europeanization of French China policy 82

3.3 The Reasoning of the French diplomacy to lift the arms embargo 87

3.4 The French response to Europeanization of China policy in the case of the arms

$\begin{array}{ll}\text { embargo } & 92\end{array}$

$\begin{array}{ll}3.5 \text { Goodness of fit } & 105\end{array}$ 
4.0 Introduction

4.1 Relations with the PRC and Track record of the Europeanization of UK-China policy

4.2 Reasoning of the British Diplomacy

4.3 British Response to the Europeanization of China policy: the case of the arms embargo

5.1 Relations with the PRC and Track record of Europeanization of China 145

5.2 Reasoning of the German Diplomacy 155

5.3 German response to the Europeanization of German policy: the case of the embargo

160

5.4 Goodness of fit

Chapter 6: Conclusion: Was there any European China Policy in the case of the embargo?

6.0 Introduction

6.1 The case of the embargo: an aberrant or normal issue for EU foreign policy? 180

6.2 Response to the embargo by other Member States

6.3 Comparison of the influence and responses of the Big Three and their impact of bilateral relations

6.4 The place of China in the world and the aspirations of the EU as a global actor 185

6.5 Applicability of adaptation theories on foreign policy 
Table Contacts France $\quad 208$

Table Contacts Germany 210

The Code of Conduct on Arms Export 216

$\begin{array}{ll}\text { Armament Industry Data } & 220\end{array}$

References 223 


\section{LIST OF TABLES}

Table 1.1 The Timeline of the EU arms embargo on China 8

Table 2.6.2: Positive respondents for the Three Member States and the EU 67 


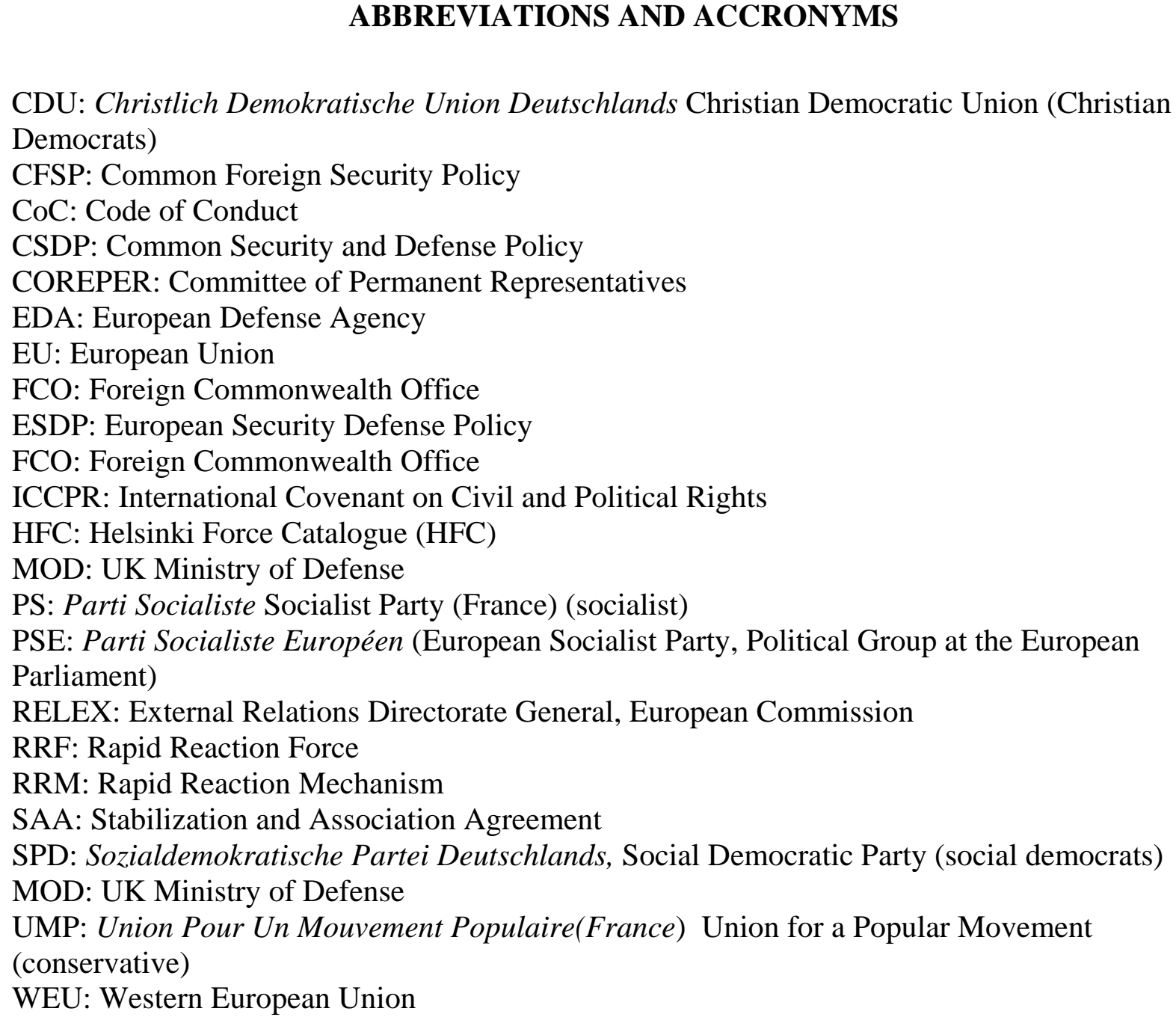

CDU: Christlich Demokratische Union Deutschlands Christian Democratic Union (Christian Democrats)

CFSP: Common Foreign Security Policy

CoC: Code of Conduct

CSDP: Common Security and Defense Policy

COREPER: Committee of Permanent Representatives

EDA: European Defense Agency

EU: European Union

FCO: Foreign Commonwealth Office

ESDP: European Security Defense Policy

FCO: Foreign Commonwealth Office

ICCPR: International Covenant on Civil and Political Rights

HFC: Helsinki Force Catalogue (HFC)

MOD: UK Ministry of Defense

PS: Parti Socialiste Socialist Party (France) (socialist)

PSE: Parti Socialiste Européen (European Socialist Party, Political Group at the European

Parliament)

RELEX: External Relations Directorate General, European Commission

RRF: Rapid Reaction Force

RRM: Rapid Reaction Mechanism

SAA: Stabilization and Association Agreement

SPD: Sozialdemokratische Partei Deutschlands, Social Democratic Party (social democrats)

MOD: UK Ministry of Defense

UMP: Union Pour Un Mouvement Populaire(France) Union for a Popular Movement

(conservative)

WEU: Western European Union 


\section{Chapter 1}

\section{Introduction}

\subsection{Introduction}

For the past twenty-five years, the People's Republic of China and the European Community/European Union have been similar and different, compatible and incompatible at the same time ${ }^{1}$. The PRC always had a choice of dealing either with Europe as an 'abstract' amalgam' of industrialized West European nation states, or with the EC/EU as the "concrete yet fuzzy and at times yet frustrating technical framework of Europe”2. At first sight, due to its own political tradition of developing close relationships before developing partnerships, China felt closer to individual European countries. China however quickly grasped the importance of the European Community as an economic powerhouse and sometimes tried to play the former against the latter. It was a logical reaction since the EC was mostly dealing with trade issues at the time it started a relationship with China. Politically then, the point of reference for China was individual states, including Britain, France and Germany who all established relations with China prior to the EC.

The EC only started its transformation into a political union (European Union) in 1992 with the Maastricht Treaty by developing a stronger identity as a foreign policy actor. The Union is far from being achieved especially when it comes to common foreign policy where domestic interests might conflict with EU interests. Today, from a EU perspective, the relation with China is at a flourishing stage. Economically, EU-China trade in goods has

\footnotetext{
${ }^{1}$ Kay Möller. “Diplomatic Relations and Mutual strategic Perceptions: China and the European Union”. The China_Quarterly: 196, (March 2002), Special Issue: China and Europe since 1978: a European Perspective: 10-33, 10

2 Möller, 11
} 
increased more than 30-fold, amounting to about $€ 146$ billion in 2003; European Commission President Barroso recently stated that the EU was at a dynamic moment in its relationship with China and that developing its relationship would be one of the Union's top foreign policy objectives. In strategic domains, multiple agreements have been signed and levels of cooperation have certainly been expanding. The EU has been supporting China's integration into global institutions in order to increase its stake in making them work more effectively. When it comes to the role of China on security issues however, Member States diverge and they have not seen any urgent need to develop collective strategic thinking related to China ${ }^{3}$. The European Union imposed an arms embargo on China following the Tiananmen Square incident in 1989 and since 2003, there have been discordant voices for a possible lift of the embargo. European policymakers are also concerned by China's policy of offering unconditional political support, economic aid and weapons to autocratic regimes that might otherwise collapse or be susceptible to international pressure (including Sudan, Iran, Burma, Zimbabwe, North Korea, Uzbekistan, Kazakhstan and Angola). Of course, China’s support for autocratic regimes is not designed to upset the West: Beijing wants access to oil, gas and other natural resources, as well as support against Taiwan at the UN. Member States cannot reach consensus because they have conflicting economic and strategic interests. Ultimately, countries tend to compete against each other to be Beijing's best political friend and trading partner thus undermining EU China policy. France and the United Kingdom for instance, as co members of the United Nations Security Council always took a more cooperative stance ${ }^{4}$ compared to

\footnotetext{
${ }^{3}$ Anthony Sipri. "Military relevant EU-China trade and technology transfers: issues and problem". (Paper presented at the Conference on Chinese Military Modernization: East Asian Political, Economic, and Defense Industrial Responses, organized by the Freeman Chair in China Studies and the Pacific Forum Center for Strategic and International Studies, Washington D.C., 19-20 May, 2005)

${ }^{4}$ Anthony Sipri. “Military relevant EU-China trade and technology transfers: issues and problem”. (Paper presented at the Conference on Chinese Military Modernization: East Asian Political, Economic, and Defense
} 
Northern European Member States who always had a less conciliatory attitude because of Chinese records on human rights. Political ties and commercial interests justified then the Franco-German crusade for a lift of the embargo. There are top-down influences from Brussels to Member States as well as bottom-up influences coming from Member States to Brussels when it comes to EU policy-making. This process is called 'Europeanization' and is defined by McGowan as the interactions and impact of the EU on domestic actors and structures ${ }^{5}$. EU China policy-making does not escape such process: Brussels tailors a EU China policy that member states’ behaviors might contradict.

This study analyzes the impact of France, Britain and Germany on EU sanction policy on China. Sanctions are an instrument of a diplomatic or economic nature that seek to bring about a change in activities or policies such as violations of international law or human rights, or policies that do not respect the rule of law or democratic principles. Arms embargoes differ from traditional EU sanctions because their implementation ultimately depends on the good will of individual member states while dealing with the embargoed country. The case of the handling of the lift of the arms embargo, imposed on the wake of the Tiananmen Square Massacre in 1989 illustrates how the EU was unable to formulate a common and coherent position in its China policy. I argue that Britain, France and Germany affect the EU sanction policy on China based on their historic and strategic ties to the PRC.

The study combines a questionnaire on China policy and sanction policy addressed to defense and foreign affairs officials from the three member states and EU officials, press articles, interviews and speeches from that period, applies the theory used by Tanja Börzel,

\footnotetext{
Industrial Responses, organized by the Freeman Chair in China Studies and the Pacific Forum Center for Strategic and International Studies, Washington D.C., 19-20 May, 2005)

${ }^{5}$ Lee McGowan. "Europeanization unleashed and rebounding: assessing the modernization of EU cartel policy”, Journal of European Public Policy 12:6, (December 2005): 986-1004, 996
} 
who recognizes three kinds of reactions from the member states to Europeanization: pacesetting, foot-dragging and fence-sitting combined with policy misfit theories by Cowles et al. and Falkner et al. to understand the responses of Europeanization and explain the goodness of fit between the three Member States and the EU policy.

I expect to find that the three states set the agenda of the European Union, formulate policies and influence other Member States to follow their policy choices through a bottom-up and horizontal process of Europeanization but that their capacity to influence such processes might be hampered by domestic and external constraints. The Three Big States have a unique vision of the place of China in the international security system that they would like to see the Common Foreign Security Policy adopt, but that might conflict with EU cohesion strategy, domestic and US interests. Our findings will also show that external factors, such as US influence, may overpower the will of the Big Three to affect the sanction policy.

\subsection{Research Problem}

I am interested in comparing the impact of the French, British and German China policies on EU China policy dealing with foreign policy and security matters. Comparing a set of policies between the EU and the main Member States with regard to China is a somewhat difficult exercise for methodological, historical, and functional reasons. First of all, the field of comparative security study is fairly recent, and there are constant evolutions of the definition of security and foreign policy. Second, from a functional perspective, the three states belong to the EU, and I compare the policies of an organization they belong to and their own policies that

might go beyond the policies of the EU. Finally, historical relations with China started at different moments. The formal relationship between the EU/EC and China began in 1975 while 
the three states recognized the PRC much earlier (with Britain being the first European power to recognize the People's Republic of China in 1950 and France the first to exchange ambassadors with the PRC in 1964, followed by Germany’s recognition in 1971).

As I mentioned, the EU China policy in the field of foreign and security policy is still young and between 1975 and the early nineties, the relationship mostly focused on trade. Trade is the most cohesive EU policy, where the EU achieved the highest level of supranational coordination. However, a political union only took shape in the late eighties through the Maastricht Treaty that established a second pillar of EU policies dealing with foreign policy issues and the first European Security Doctrine which followed in 2003. The political union also occurred in the context of the Tiananmen Square incident in 1989. Records on human rights and the fact that the Chinese political system did not fit any traditional Western democratic regime model prevented Member States from adopting a common stance. Member States have conflicting opinions about tying deeper political cooperation with progress on human rights records or not. I established earlier that Britain, France and Germany had a very special interest in EU China policy. The three states have a historical relationship prior to the EC/EU and have prime strategic importance in shaping EU foreign policy. Britain, France and Germany are the most influential Member States when it comes to defense issues, because they have the largest defense resources (army, manpower and budget). As member states of the European Union, the Big Three participate in the European Security Defense Policy (ESDP); they also have an overlapping membership with NATO, another major security provider for Europe. The NATO membership brings up the importance of another actor outside the European Union regarding European security matters: the United States. The United States as 
the only superpower always seemed a proponent of a more autonomous European Union provided that it did not conflict with U.S. interests.

Based on their historical relationship with China, the three countries have been developing their own perception and vision of China's role in world security which might conflict with US's own perception of China. In particular, the three Member States' leadership contributed to define the status of partnership with China: whether China was a strategic partner, a special partner, or just a partner to cautiously handle cautiously. I am specifically interested in how much influence the three Member States had in carving this partnership between the EU and China. Some scholars argue that individual European countries have been losing influence to the benefit of the $\mathrm{EU}$ as a whole ${ }^{6}$. There has been a top-down Europeanization of the three member states’ foreign policy vis-à-vis China and their policies have been converging. However, the Franco-German initiative for a lift of the embargo showed that the big member states were very capable of shaping the agenda. I want to assess the process of Europeanization in EU policy vis-à-vis China. Is there a horizontal Europeanization on EU China policy where Britain, France and Germany pushed for ideas across the Union? Or did the EU supply much coordination leading to a convergence in their policies? Do individual member states pursue an individual strategy and try to upload their vision of a China policy at the EU level? Ultimately, the role of China in the world security is at stake: Do the bilateral relations, such as between France and China or the United Kingdom and China, and state-centered perceptions help or hinder the development of a coherent EU security policy? Do state interests prevail when it comes to China or is there a basis to develop

\footnotetext{
${ }^{6}$ Reuben Wong. “Towards a Common European Policy on China” (paper presented at the conference 'The European Union and the World: Asia, Enlargement and Constitutional Change', organized by IPSA Research Committee 3 on European Unification, in Beijing, 5-6 May 2005).
} 
a common strategy? When it comes to building partnerships with the PRC, do other actors in the international system intervene e.g. the U.S.?

Theory: Britain, France and Germany have a significant impact in shaping the EU sanction policy on China due to their strategic and historical bonds with the PRC and their key role in the EU.

$H_{1}$ or Null Hypothesis: The influence of the three member states is negligible, dissolved in EU because the EU dictates the strategic choices regarding China policy through the CFSP and downloads its policies, leading to convergence.

$\mathrm{H}_{2}$ : The Big Three influence the agenda-setting and policy formulation of EU policy visà-vis China, and upload their policy preferences

$H_{3}$ : The Big Three influence other Member States to have them follow their policy choices regarding EU policy by exchanging ideas through horizontal Europeanization.

H4: The Big Three may influence the agenda-setting and the policy formulation of EU China policy but the implementation of the given policy is inherently tied to U.S. approval, due to its strategic interests in the region

To test our hypotheses, I chose the case of the lifting of the arms embargo imposed on China following the Tiananmen uprising. Arms embargoes represent an original EU sanction since their implementation ultimately depends on the discretion and compliance of the individual member states. The lift of the arms embargo is an issue where the EU has been struggling in reaching common agreement. 
Table 1.1 The Timeline of the EU arms embargo on China

June 6, 1989: The European Council imposed a series of punitive measures on China for its violent repression of the Tiananmen democracy movement.

May 25, 1998: Member States adopted the Code of Conduct on Arms Exports, outlining principles and guidelines based on eight criteria for future exports of military equipment.

December 2003: In visit to China, Chancellor Gerhard Schröder told Premier Wen Jianbao that "the time had come” to lift the embargo

December 12, 2003: The European Council instructed its foreign ministers (General Affairs Council), under the initiative of President Chirac from France to 're-examine the question of the embargo on the sale of arms to China'.

December 18, 2003: The European Parliament rejected the lift by a landslide vote (373 in favor, 32 against) due to continuing violations of human rights

January 26, 2004, EU foreign ministers failed to reach an agreement after discussing the issue. They asked two working groups, the Committee of Permanent Representatives (COREPER) and the Political and Security Committee, to examine the matter further.

January 27, 2004: President Chirac from France, at a joint conference with visiting Chinese President Hu Jintao, publicly called for the lifting of the arms embargo on China.

April 26, 2004: The European Council discussed the embargo and called for further discussion

October 11, 2004: The European Council of Foreign Affairs Ministers reviewed the state of discussions on the embargo. It also took a series of decisions on the EU-China

Dialogue on Human Rights.

December 8, 2004: The EU confirmed its intention to 'continue to work towards lifting the embargo'.

March 14, 2005 The PRC People's Congress adopts the Taiwan Anti-Secession Law which inflicted a severe blow to the initiative

March 14-19, 2005: A European Union defense team visits Washington to explain the proposal to lift its Tiananmen Square arms embargo on China without convincing their U.S. counterparts.

April 14, 2005: The European Parliament approved a resolution that called on the European Council not to lift the arms embargo on China

July 1, 2005: The UK takes over the EU presidency and does not put the embargo issue on the agenda November 2005: German Chancellor Elect Merkel opposes the lift 


\subsection{Timeline and background information about the embargo issue}

Following the 1989 Tiananmen massacre, the European Council meeting in Madrid issued a document imposing a number of EU-wide diplomatic and economic sanctions on China, including an arms embargo ${ }^{7}$. The EU embargo is somewhat vague and, as a result, it has been interpreted differently by individual EU member states. Because there was no common list of embargoed goods, the embargo never became EU coherent in its implementation and scope. Despite a general restraint with regard to signing new contracts ${ }^{8}$, EU member states continued to sell goods after June 1989, which could be used as weapons by China. Those goods were identified as 'dual-use technology products' or 'non-lethal defense items', i.e. s radar systems, aero-engines, communications systems, and even satellite technology. The commercial and military opportunities for European companies in China were huge. The European arms industry was attracted to China's untapped defense market that was so far almost exclusively monopolized by Russian arms manufacturers: in 2002 alone, Chinese purchases of foreign weapon systems were valued at \$3.6 billion which Russian received.

Any decision to lift the arms embargo would need the unanimous agreement of all EU member states. The process itself could take place at the European Council, a meeting of EU heads of government, or at the monthly meetings of the foreign ministers ${ }^{9}$. At the European Council Meeting in Brussels in 2003, chief executives of the Member States invited their foreign ministers to reexamine the need for the arms embargo and the arguments for and

\footnotetext{
${ }^{7}$ Eugene Kogan. “The European Union Defense Industry and the Appeal of the Chinese Market”. (Report, Studien und Berichte zur Sicherheitspolitik, Schriftenreihe der Landesverteidigungsakademie, January 2005), 12

${ }^{8}$ Kogan, 16

${ }^{9}$ Kogan, 12
} 
again its removal ${ }^{10}$. A number of EU leaders made statements that China was very different politically from other countries on which the EU had imposed arms embargoes. EU leaders also recognized that China's leadership had changed since 1989 and that there had been dramatic changes in Chinese society. ${ }^{11}$

France and Germany were the champions of the lift and Britain did join the process. With other members, France and Germany claimed that the embargo hindered stronger EU political and economic relations with China. While visiting Beijing in December 2003, German Chancellor Gerhard Schröder told Premier Wen Jianbao that "the time had come" to lift the embargo. That same month, during a summit of EU member states, French President Jacques Chirac led European leaders in referring the issue to their respective foreign ministers (General Affairs Council), urging them "to re-examine the question of the embargo on the sale of arms to China". ${ }^{12}$ However, in December 2003, the European Parliament rejected the lift by a landslide vote (373 in favor, 32 against) due to continuing violations of human rights. The European Parliament, before the Lisbon Treaty did not have any authority in foreign policy making and was only an advisory body, but the landslide result sent a strong signal to heads of government across the EU that the move was not the wisest and the most popular.

At their first meeting of the year in Brussels in January 2004, EU foreign ministers failed to reach an agreement after discussing the issue. They asked two working groups, the Committee of Permanent Representatives (COREPER) and the Political and Security Committee, to examine the matter further. The day after the ministerial meeting, then

\footnotetext{
${ }^{10}$ European Union Council. “Brussels European Council Presidency Conclusions”, December 12-13, 2003

${ }^{11}$ Sipri, 9

${ }^{12}$ Frank Ching. “Changing dynamics in EU-China arms relations”. China Brief, Volume 4, Issue 5 (March 8, 2004), 1
} 
President Chirac, at a joint conference with visiting Chinese President Hu Jintao, publicly called for the lifting of the arms embargo on China. On April 26, 2004, the Council discussed the embargo, noting that "it had been imposed as a response to specific events in 1989 and that a solution for the matter had to be found which was in line with the current situation in China, the increasingly close bilateral relations and the EU's intention to develop a strategic partnership with China”. The matter was further referred to the Permanent Representatives Committee and the Political Security Committee. The fact that the repeal could not be concluded prior to the 1 May 2004 accession of ten Eastern European and in some cases proU.S. states into the European Union served as one of the greatest blows to a quick resolution of the arms ban. ${ }^{13}$ On 11 October 2004, the ministers reviewed the state of discussions on the embargo. The Council's overall assessment was that there was a 'mixed picture of progress in some areas and continuing concerns in others'. On 8 December 2004 in The Hague, the EU Council confirmed its intention to 'continue to work towards lifting the embargo'. Throughout 2005, senior EU officials, especially Javier Solana, High Representative for Foreign and Security Policy continued to describe the arms embargo variously as 'unfair', 'anachronistic' and 'insignificant' in terms of positive influence on the policies of the current Chinese leadership. But once again, on April 14, 2005, the European Parliament challenged the view of the member states and approved a resolution that called on the European Council not to lift the arms embargo on China, decision based on poor human rights and the large number of missiles in southern China aimed at Taiwan (431 in favor to 85 against) ${ }^{14}$.

\footnotetext{
${ }^{13}$ Saalman Lora, Yuan Jing-Dong. “The European Union and the Arms Ban on China”. (Center for Non Proliferation Studies (CNS), Monterey Institute of International Studies, July 2004), p.5

${ }^{14}$ Austin Greg. “The 1989 China Arms Ban: putting Europe’s position to Congress”. The Foreign policy Centre, (April 2005), 6
} 
Among Member States, there was a debate on the desirability and the conditions of the lift. On one hand, China did not belong to the same category of 'pariah' countries such as Myanmar, Sudan and Zimbabwe - the three other countries against whom there were an EU arms embargo. On the other hand, the human rights record did not seem sufficient, and Member States feared the use of European technology by China. As a safeguard, the EU came up in 1998 with the "Code of Conduct" on arms sales. The Code of Conduct barred the sale of equipment that could be used in regional conflicts or domestic repression, which would still be enforceable on sales to China. This meant that even if the EU did lift the embargo, sales of certain weapons would still be illegal, ${ }^{15}$ and the EU promised not to lift the embargo until it had strengthened its Code of Conduct on Arms Exports and introduced a transitional regime for recently embargoed countries $^{16}$. The Code of Conduct would prevent a radical change in the strategic balance in Asia-Pacific region.

France, Germany, and Spain made the case that the ban should be lifted without placing conditions upon its removal, while Britain argued that a reinforcement of the Code of Conduct on Arms Sales would help. ${ }^{17}$ The proposal for lifting the arms ban was partially driven by economic and political considerations. Expanding with China at all levels was an important part of European efforts to stimulate economic growth. In arguing for a lifting of the ban, French Foreign Minister Dominique de Villepin stated "Our feeling is that the embargo is out of date as relations between Europe and China improve. ... [Beijing is] a privileged partner and a responsible one. ”18 The French stance also resulted from Chinese pressure on its French partner,

\footnotetext{
${ }^{15}$ Ching, 2

${ }^{16}$ Eugene Kogan. “The European Union Defense Industry and the Appeal of the Chinese Market”. (Report, Studien und Berichte zur Sicherheitspolitik, Schriftenreihe der Landesverteidigungsakademie, January 2005), 14

${ }^{17}$ Saalman et al., . 3

${ }^{18}$ Wolfe Adam. "France and Germany Move to Resume Arms Sales to China," Power and Interest News Report, (11 February 2004).
} 
and also pressure from domestic French weapon manufacturers. The main argument was that China had dramatically changed and improved in many areas since 1989, including human rights abuse. The arms embargo in President Chirac's opinion was 'a relic of the Cold War'19. At the same time, Germany suffered from a greater degree of domestic debate and opposition because of the Germany-Taiwan friendship group and the Green Party’s objections to perceived ongoing human rights abuses in China ${ }^{20}$. The UK showed an interest in reconsidering the ban, arguing that the European Union's Code of Conduct on Arms Export, while not legally binding, with some enhancements would provide a solid safeguard against worrisome arms exports by EU states to the Chinese in the future ${ }^{21}$.

On the other side of the aisle, the Netherlands, Finland, Belgium, Portugal and Sweden voiced concerns over lifting the ban without significant improvements in China's human rights, but their position did not seem irreconcilable. The Netherlands and Denmark in January 2004 demonstrated a willingness to agree to lift of the weapons embargo if it represented the will of the majority of states. Several non-EU members also joined the chorus: Russia, as mentioned was China's primary source of China's military equipment since the imposition of the 1989 embargo (\$2.1 billion of China's total arms purchases in 2002) along with Israel and both countries were not keen on giving up a significant market share. Yet by far the loudest opponent had been the United States. While much of the European rhetoric regarding the ban tended to focus on the economic implications, Washington was more concerned with the strategic implications of the lifting of the arms embargo. China demonstrated a particular interest in

\footnotetext{
${ }^{19}$ Ibid.

${ }^{20}$ Berliner Zeitung "German Greens Criticize Government Arms Export Report, Urge Restrictive Exports," 12 March 2004

Taipei Central News Agency “CNA: Germany Urged Not to Support Easing of Arms Sales Ban to China,” , 8 April 2004.

${ }^{21}$ Grimmett Richard et al. “European Union’s Arms Control Regime and Arms Exports to China: Background and Legal Analysis”. (Report for Congress, March 1, 2005), 2
} 
systems that could be used against U.S. forces in a potential conflict over the Taiwan Strait. The Transatlantic relationship was damaged from the rift about the invasion of Iraq and both sides were keen on repairing it. The passage on the Anti-Secession law in March 2005 was a severe blow to the initiative. China was warning that any move by Taiwan towards independence would be considered as an aggression against mainland China (See Appendix).

Despite a EU diplomatic offensive to convince the US partners and the launch of a EUUS Dialogue in China, the Anti-Secession Law comforted opponents to the lift in their opinion and contributed to convince skeptics. The weakening of France following the rejection of the referendum about the EU Constitution in the spring of 2005, the prudent attitude of the Blair government and the electoral campaign in Germany helped burry the issue.

\subsection{The US interference in the debate}

As soon as the U.S. got wind of a possible removal of the embargo by the EU, intelligence officers were sent to several EU member states to convince them that the embargo should remain in place. Following the January 2004 Foreign Ministers Council decision to look into the feasibility of the lift, US diplomacy issued several complaints with the EU, arguing that the EU embargo was complementary to the US embargo, and both were imposed for the same reasons.

In an effort to mend fences after the tensions provoked by the Iraqi crisis, US President George W. Bush appeared resigned to the likely EU decision to lift the embargo on his February 2005 European tour. However, a couple of months later, the US House of 
Representatives passed a bill in the spring that would restrict military exports and technology- I -sharing with those European countries that sell arms to China. ${ }^{22}$

The US lack of consistency reflected two schools of thought in the US strategy towards China: one believed that China should be better integrated into the international community; the other preferred to contain China militarily and economically. ${ }^{23}$ The latter seemed defiant of a closer relationship between the PRC and the EU and was wary of the notion of "strategic partnership". The US feared that the deepening of Sino-European political relations reflected a hidden agenda to create a multipolar world to counter US influence. ${ }^{24}$ Given the US commitment to Taiwan, there were fears in Washington that balance of forces between China and Taiwan would be affected were the PRC to acquire sophisticated arms. ${ }^{25}$

\subsection{Significance for the Literature and Chapters Overview}

The contribution to the literature is significant since there had not been many comparative studies on Europeanization applied to foreign policy. As the literature shows, studies of Europeanization in foreign policy cover one country and do not compare three member states. The study may also contribute to the literature through the use of policy misfits and adaptation theories. Most of the work in the literature (Börzel 2000, Falkner et al. 2005, Cowles et al. 2001) covers harmonization and compliance at the domestic level and did not include foreign policy.

Chapter 2 starts by reviewing the key concepts related to the EU sanction policy, Common Foreign Security Policy, relationship between Member States and EU institutions and

\footnotetext{
${ }^{22}$ Kreutz, 53

${ }^{23}$ Crossick et al., 17

${ }^{24}$ Crossick et al., 33

${ }^{25}$ Crossick et al. 16
} 
an extensive discussion of Europeanization. The chapter continues by presenting the methodology used in the study: a questionnaire combined with official documents, press articles and the application of three theories allowing us to understand responses from member states to the Europeanization of their China policy.

Chapter 3, 4 and 5 analyze the countries of the study, i.e. France, Britain and Germany. These chapters follow the same structure. They start with a history of the relationship of the given country with China, then its impact on EU China policy, then its reasoning regarding the lift of the arms embargo and then looks into the level of adaptation to EU China policy in the case of the embargo.

Finally, the last chapter offers a comprehensive review of the findings and opens the discussion on the role of China in the international sphere and how the transatlantic relationship gets affected by it. 


\section{Chapter 2}

\section{Definition of Concepts}

\subsection{Introduction}

I will now review the literature of the different concepts mentioned in the study: the role, attributes and functioning of the EU Common Foreign Security Policy, a definition of sanctions, a discussion of the concept of security, an analysis of the concept of Europeanization and its application to foreign policy, and finally the theories of Tanja Börzel and Cowles et al. and Falkner et al. on the responses to Europeanization

\subsection{Formulation and conduct of Foreign Policy in the European Union}

The study reviews the influence of member states on EU sanction policy. Sanctions or 'restrictive measures in force' are adopted in the framework of the Common Foreign Security Policy. They are under the European Commission External Relations Directorate but decided by the European Council of Member States. Sanction policy illustrates the complexity of the EU foreign policy. The CFSP was recently modified under the 2009 Lisbon Treaty. For the purpose of our case study which was between 2003 and 2005, we need to review how the CFSP functioned then, meaning pre-Lisbon Treaty.

\subsubsection{Short History of the Common Foreign and Security Policy}

The Maastricht Treaty of 1992 was the first to contain provisions on the EU's responsibility for all questions relating to its security, including the eventual framing of a common defense policy. The war in Bosnia-Herzegovina had definitely been an impetus. In August 1991, 
the twelve members requested the Western European Union (WEU) to assess options for deployment of a European interposition force of 30,000 troops without US or NATO support. But in September 1991, the Netherlands, Portugal and the United Kingdom vetoed WEU involvement, arguing that military operations should exclusively remain a NATO competence ${ }^{26}$. From the point of view of military capabilities, Europe's ability was never questioned: it has always been a political and ideological issue. The Maastricht Treaty defined these tasks as part of the Common Foreign and Security Policy. But the idea of having cooperation in terms of foreign policy had been brought up as early as in the 1970s with European Political Cooperation (EPC), a mechanism for foreign policy coordination among member states. EPC was transformed into the CFSP, like a caterpillar to a butterfly, during the 1991 EU Intergovernmental Conference (ICG).

The CFSP was established as the second pillar of the European Union in the 1993 Treaty on European Union signed at Maastricht. The Treaty envisaged that the EU, having no military capabilities of its own, would request the Western European Union (WEU) to elaborate and implement planned military measures on its behalf. The 1997 Treaty of Amsterdam incorporated into the Treaty on the European Union the Western European Union's (WEU) "Petersberg tasks", establishing which types of military operations the EU can undertake. The most extended definition has been included in Article III-309 of the draft of the European Union Constitution: ‘joint disarmament operations, humanitarian and rescue tasks, military advice and assistance tasks, conflict prevention and peace-keeping tasks, tasks of combat forces undertaken for crisis management, including peace-making and post-conflict stabilization.”27 This laid the treaty basis for the operative development of the European Security Defense Policy.

\footnotetext{
${ }^{26}$ Sven Biscop, “Able and Willing? Assessing the EU’s capacity for military action”, European Foreign Affairs Review 9 (2004): 509-527, 512

${ }^{27}$ Biscop, 512
} 
The project of developing an independent European Security and Defense Policy (ESDP) was officially launched by the 1999 Cologne European Council, which agreed to embark on a Common Security and Defense Policy (CESDP) within the overall framework of the CFSP. The aim of ESDP was and still is to complete and thus strengthen the EU's external ability to act through the development of civilian and military capabilities for international conflict prevention and crisis management ${ }^{28}$. With the 1998 St Malo Initiative, France and Great Britain developed "the capacity for autonomous action, backed up by credible military forces in order to respond to international crises. ${ }^{29 "}$ There was a stated desire for the EU to make decisions and approve military action where NATO as a whole was not engaged. The two governments also agreed to develop within the EU institutional framework the ability to deploy a European Rapid Reaction Force within sixty days (up to 50,000-60,000 men). The German government, which occupied the rotating six-month presidency of the EU in the first half of 1999, welcomed the French-British declaration and quickly placed the strengthening of a common security and defense policy at the top of its EU agenda. ${ }^{30}$

At the Cologne Summit on 3 June 1999, European leaders agreed on a common defense strategy. Their stated desire to incorporate the dormant WEU into the EU by the end of the year 2000 was effectively achieved by the Marseilles Declaration of November 2000. The Finnish presidency included the St Malo initiative in the Headline Goal (HG) agreed at the Helsinki European Council (December 1999). The Headline Goal aimed to make available to the EU necessary capabilities, including the necessary command and control, intelligence, logistics and air and naval assets, to enable the deployment of 60,000 troops within 60 days and for a sustainable

\footnotetext{
${ }^{28}$ Euractiv.com "EU Security and Defence Policy”, Policy Summary, last modified January 5, 2006 http://www.euractiv.com/Article?tcmuri=tcm:29-117486-16\&type=LinksDossier

${ }^{29}$ Franco-British Summit, Joint Declaration on European Defense, (St Malo: December 4, 1998)

${ }^{30}$ Constantine Pagedas (2001) "Post-Ismay Europe: Britain and the Rebalance of European Security", Mediterranean Quarterly, (12-4, 2001), 8
} 
year. Given the need to rotate forces the HG would require a pool of some 180,000, allowing for forces on standby and standing down equal to the force deployed. As defined in the Capabilities Development Mechanism (CDM), follow-up of the Headline Goal is ensured by a working group of experts, the Headline Goal Task Force (HTF), with the support of the EU Military Staff $\left(\mathrm{EUMS}^{31}\right.$.

The Treaty of Nice (2000) made the St Malo Initiative a reality, creating the Rapid Reaction Force. Some Treaty amendments truly reflected the operative development of the ESDP as an independent EU project. One could argue that France and Britain were true engines of Defense integration despite their different visions on the role of NATO. However, in the midst of the Iraqi crisis, the traditional Franco-British axis was strained. Instead of stopping European defense integration, France, Germany, Belgium and Luxembourg took the lead to launch plans for a EU planning capability, also known as the Tervuren initiative ${ }^{32}$. But because of its timing, and the strains in EU-US relations over the war in Iraq, the so-called Tervuren initiative was seen in London as a deliberate snub to Prime Minister Tony Blair. German officials at the time said Mr. Blair dropped his earlier reluctance to the initiative in exchange for assurances that the club would remain open to other EU members at all times. At a summit held in Berlin in September 2003 to mend fences, the three major powers confirmed their attachment to common initiatives. An internal document approved by Britain, France and Germany said: "The European Union should be endowed with a joint capacity to plan and conduct operations without recourse to NATO resources and capabilities. Our goal remains to achieve such a planning and implementation capacity either in consensus with the 25 (member states) but also in a circle of interested partners.” About a year

\footnotetext{
${ }^{31}$ European Council, “Helsinki European Council Summit: Presidency Conclusions”, Helsinki, Finland: December 10-11, 1999

${ }^{32}$ Benoit Bertrand et al.. "Blair backs EU plans for joint defense project”, The Financial Times, September 22, 2003
} 
later, EU defense ministers agreed in November 2004 to establish thirteen so-called battle groups that would be deployable rapidly for crisis management around the world outside the NATO framework at the request of the United Nations. The groups, each 1,500-strong (one battalion plus supporting units) can be deployed within ten days of the decision to launch an operation and are sustainable for 120 days until the termination of the operation or until relief by another, longerterm force, deployed by the EU, the UN or regional organization such as the African Union. By 2007, between seven and nine battle groups, either national or multinational, were to be made available, adding 10,500 to 13,500 rapidly deployable combat troops for high-intensity operations of the Helsinki Force Catalogue (HFC). ${ }^{33}$

The evolution of ESDP did not betray its original purpose, which was to provide military and civilian assets for international conflict prevention and crisis management. Since the EU sought to promote non-violent settlement of conflicts, alongside the military capabilities, the EU aimed to emphasize the development of civilian capabilities which focus on the four priority areas (police, rule of law, civilian administration and civil protection capacities) adopted at the June 2000 Feira European Council. US decision-makers always felt reluctant to see the ESDP expand though ESDP seeks to strengthen and consolidate the EU's alliance with the US and Canada within the framework of NATO, and also by complying with the principles of the Charter of the United Nations. ESDP's purpose was not to replace but to complement NATO. Member States armed forces remain under the control of their national commanders and will only be led by a military supreme commander for the duration of any EU mission.

\footnotetext{
${ }^{33}$ Biscop, 517
} 


\subsubsection{Role and attributes of the EU institutions in the CFSP}

The EU's efforts to assume a political role have been handicapped by awkward institutional arrangements, designed to separate the CFSP from the usual EU decisionmaking process with its greater limits on state sovereignty. The 2009 Lisbon Treaty addressed most of the institutional challenges and some decision-making unbalances. But whether it was before or after Lisbon, the EU has multiple institutions to deal with foreign and defense policy. These institutional issues reflect the contradictions between the ambitions of EU member governments to play a larger international role and their reluctance to move beyond an intergovernmental framework in doing so. ${ }^{34}$ It resulted in a constant power struggle between the Commission and the Council, since Member States were (and still are in 2010) the primary decision-makers despite a few responsibilities assigned to the Commission. The CFSP was not like the Common Commercial Policy. Other forms of EU external action might rather be understood as being based on the 'traditional Community method'. Trade policy, for instance, has been characterized by a considerable delegation of responsibilities to the Commission for developing and managing policies, instruments and agreements. ${ }^{35}$ The member states have not surrendered national sovereignty to supranational institutions for foreign and security policy, let alone defense policy in the EU. Foreign and Security policy is neither an exclusive EU competence nor an area of mixed EU-member state competence. Foreign and security policy is one area where essential authority remains

\footnotetext{
34 Ann Deighton Ann “The European Security and Defense Policy”, Journal of Common Market Studies, Vol.40, Number 4, (November 2002): 719-741, 730

35 Paul Jonas "EU Foreign Policy After Lisbon: Will the New High Representative and the External Action Service Make a Difference?” (Report Center for Applied Policy Research (C·A·P), No 2, June 2008), 7
} 
with EU governments, although the European Commission and, to a lesser extent the European Parliament, are associated with the process. ${ }^{36}$

The Commission since Maastricht has been 'fully associated with the work carried out in the common foreign and security policy field' (article 27 Treaty of the European Union) through its right of policy initiative (though not exclusive as it is in 'core' EU competencies in the then 'first' pillar), its budgetary powers and by representing the EU through a network of delegations. The Commission was still responsible for a big part of external relations: it had sole responsibility for Community actions in the areas of humanitarian, development assistance, rehabilitation and reconstruction and sanctions regulations.

Over the years, the Commission increased through informal and institutional measures its autonomy vis-à-vis the Council. For instance, the Commissioners entrusted with foreign affairs have always tried to coordinate and focus their efforts. The Council of Ministers meetings have been attended at least by six RELEX Commissioners (from the French Relations Extérieures). The Commission has been participating in meetings at the working levels of the Council (COREPER and working parties). On the international stage, the establishment of Independent General Directions, for instance, allowed the Commission to benefit from network of 150 embassies worldwide. The creation of the Rapid Reaction Mechanism in February 2001 was another measure that allowed the European Commission to dispatch community funds rapidly in case of an emergency. The creation of the RRM was a response to the new EWU development in crisis management, such as the Situation Center, within the Council.

\footnotetext{
${ }^{36}$ European Commission. “Speaking with one voice: Overview”, http://europa.eu/pol/cfsp/index_en.htm
} 
Before Lisbon, the European Parliament only had a consultative role on the developments of the CFSP. The European Parliament could ask questions to the Council and make recommendations to it. ${ }^{37}$ Through its Committee on Foreign Affairs, the European Parliament had regular contact with the EU's High Representative for the CFSP, regarding member accession, international agreements with non-member countries. ${ }^{38}$ The main area of interest for the Parliament remained the human rights issue and that, often put the Parliament in conflict with the European Council. The Parliament's Committee on Foreign Affairs directly addressed the human rights issue outside the Union through annual reports on each of these countries and monthly meetings during which breaches on human rights, democracy and the rule of law were discussed and could eventually be followed by a resolution condemning governments in case of breaches.

Before Lisbon, the key role went to the European Council (which is actually still the case after Lisbon). Member states had set up an elaborate system at the EU level in an intergovernmental pillar of the Treaty on the European Union (TEU) to coordinate their policies more closely and to attempt to devise common strategies, reach common positions, and take joint actions on a wide range of issues. ${ }^{39}$ The Council was presided over for a period of six months by each member state in turn, in accordance with a pre-established rotation. The Presidency was assisted by the Council Secretariat and the SecretaryGeneral/High Representative. The High Representative for CFSP, Javier Solana at the time, had three job titles. First, he was the Secretary General of the European Council; secondly,

\footnotetext{
${ }^{37}$ Shulz Stefan "Foreign Policy: Aims, Instruments and Achievements", European Parliament, Fact Sheets on the European Union., July 2008 http://www.europarl.europa.eu/parliament/expert/displayFtu.do?language=en\&id=74\&ftuId=FTU_6.1.1.html ${ }^{38}$ Shulz, "Foreign Policy", 1

39 Dinan Desmond, Ever closer Union: an introduction to European Integration, (Lynne Rienner Publishers: 1999), 510
} 
he was the Secretary General of the Western European Union, which is the quasi defense arm of the European Union. And thirdly, he was the High Representative for the Common Foreign and Security Policy. He essentially had to deal with the political and military aspects of ESDP. In other words, he had to integrate as much of the Western European Union into the EU as is possible, set up the structures, and make sure the member states are meeting their targets on capabilities.

The Council of Foreign Ministers, also known as the General Affairs and External Relations Council (GAERC) was the main decision-maker. It would meet monthly to discuss foreign policy and institutional issues and would define and implement the EU's Common Foreign and Security Policy on the basis of guidelines set by the European Council. The Council's formal positions were published as "conclusions" or "statements" of the Council. Declarations were also issued by the Presidency and the High Representative. Since the late 1990s, EU defense ministers also got somewhat involved. Although there was no formal Defense Council as such, at least one informal meeting of defense ministers is held during each presidency and defense ministers attend one session of the External Relations Council devoted to politico-military issues.

The Permanent Representatives Committee (COREPER) and the Political and Security Committee (PSC) prepared the work of the Council, with COREPER preparing the work of the Council as a whole and the PSC dealing with political and security issues. Working parties dealing with CFSP, composed of experts from EU Member States and the Commission, met along geographical lines (covering, for example, Asia) and thematic lines (covering, for example, human rights) prepared PSC and COREPER meetings. They made joint analyses of the situation in third countries and of multilateral issues and they drafted 
possible common positions. They drew up proposals for measures to implement the CFSP, such as declarations by the presidency on behalf of the EU, for approval by the PSC and then by the Council. They also formulated recommendations to the PSC for future initiatives in the field of the CFSP. ${ }^{40}$

In terms of decision-making, decisions before the Lisbon Treaty were taken unanimously except in the implementation of some joint actions. Until 1997, each Member State had a veto right over the formulation of a common position. The 1997 Amsterdam Treaty sought to resolve that problem with the introduction of the concept of "constructive abstention." Henceforth, a member state that did not like a proposal could abstain and not be obliged to apply the resulting decision. But the abstaining government had to accept that the decision committed the Union and must refrain from doing anything that would conflict with the EU action. ${ }^{41}$ The unanimity requirement was criticized for limiting the field of action of the EU. In addition, other than in Pillar I policies, member states are fairly free to decide whether they want to use the EU at all for pursuing certain policies in the area of CFSP ${ }^{42}$, or whether they prefer to go ahead alone or in case-specific coalition which happened in the case of the embargo. One of the recurrent criticisms against the CFSP has been the lack of enforcement compared to first pillar policies: namely, the European Court of Justice's jurisdiction is excluded from the area of $\mathrm{CFSP}^{43}$.

The institutional arrangement before Lisbon also suffered from some inconsistencies. Decision-making power and implementing capacity did not for instance match. CFSP is

\footnotetext{
${ }^{40}$ Council of the European Union. "Annual report from the High Representative of the Union for Foreign Affairs and Security Policy to the European Parliament on the main aspects and basic choices of the CFSP 2009” accessed November 14, 2010, http://www.consilium.europa.eu/showPage.aspx?id=248\&lang=EN

${ }^{41}$ Dale Reginald, “The search for a Common Foreign Policy”, Europe, Issue 388 (July/August 1999)

42 Jonas, 9

${ }^{43}$ Jonas, 10
} 
decided by the Council and implemented by the Council presidency and the High Representative. However, the Council Secretariat which is the supporting structure of the Council, primary decisions-maker for CFSP, lacked manpower (roughly 400 and two offices abroad), technical and financial resources. Paradoxically, the Commission, a secondary decision-maker for CFSP matters, disposed of 2260 staff in the RELEX office in Brussels and 4755 personnel in its 123 delegations abroad. Indeed, it often fell to the Commission to implement parts of CFSP decisions; it also played a key role in long-term conflict prevention, an important concern of CFSP ${ }^{44}$.

Naturally, the Commission wanted to see its prerogatives expand. Following the German reunification, EU member states recognized the link between European Monetary Union, CFSP and Political Union. Twenty years later, the link between those three did not necessarily lead to deeper integration. Euroskeptiks and intergovernmentalists argued that foreign policy must remain a matter for national governments. They refused to see some responsibility over foreign policy given to the European Commission and European Parliament. This school of thought championed reinforcing the Council to give the EU more legitimacy, because elected member states politicians would take decisions. ${ }^{45}$ The big member states traditionally resisted the Commission's ambitious demands for wider powers at the expense of the Council. But smaller countries despised any proposal that appeared to challenge the power of the Commission and saw it as an attempt to undermine the body that protected their interests. However, the perception that the Commission was a secondary decision maker in foreign policy was, as we proved earlier, entirely wrong. The Commission was for instance highly involved in the conduct of EU's trade related external relations. The heart of the problem with the multi-faceted profile of EU's foreign policy was that

\footnotetext{
44 Jonas, 11

45 George Parker and Daniel Dombey. “Dual ambitions”, The Financial Times, May 24, 2002
} 
the Commission had never been invested with a similar central role in the CFSP ${ }^{46}$. The Commission fought for a long time against its weak role in the CFSP, but lost all major engagements.

But there is a constant feeling that the Commission might be left out and ignored by the Council. The External Relations Directorate General - that coordinates all aspects of the Union's policy towards a country to make sure it does not encroach upon Commission responsibilities ${ }^{47}$. under Commissioner Christopher Patten was not a DG trying to push for more Commission visibility in the field of CFSP but rather was a DG trying to protect the competencies acquired in the past and to deliver efficient and effective policies. The Commission was extremely sensitive concerning any potential loss of competency in external relations. However, in some cases, the Commission has been proactive and crises had been solved under its leadership. For instance, the signature of the Stabilization and Association Agreement between the Commission and the FYROM was a strong incentive that the High Representative Solana used to pressure the two parties to reach a deal ${ }^{48}$. Indeed the SAA gives the FYROM the status of a potential candidate, thus opening up the possibility of future accession to the EU.

The issue of representation prevented greater coherence of the CFSP but was addressed by the Lisbon Treaty. Externally, the EU often sent three representatives to international meetings, one from the Presidency, one from the Commission (either its President or the External Relations Commissioner) and the High Representative: Secretary Kissinger always wondered whom to call when a European foreign policy needed to be discussed. Internally and externally, it appeared that there was no clear political leadership - no single individual able to drive change and act as a

\footnotetext{
46 Gisela Muller-Brandeck-Bocquet "The new CFSP and ESDP Decision-Making System of the European Union”, European Foreign Affairs Review 7: 257-282, (2002)

47 Piana Claire, “The EU's Decision-Making Process in the Common Foreign and Security Policy: the Case of the Former Yugoslav Republic of Macedonia”, European Foreign Affairs Review 7: 209-226, (2002), 220

48 Piana, 223
} 
figurehead for the EU's citizens. The External Affairs Commissioner concentrated very much on financial and economic assistance, including trade. Christopher Patten, former External Commissioner called himself the "quartermaster of the European Union" and the High Representative was a kind of general. ${ }^{49}$ The former President of the Commission, Romano Prodi, proposed taking some of the initiative in foreign policy away from member states, by placing the EU high representative in foreign affairs within the Commission. The High Representative, not the states, would formulate policy, although EU leaders would decide to adopt it or amend it. Britain and France did not want a foreign minister drawn too closely to the Commission, and away from the control of member states. ${ }^{50}$

The 2009 Lisbon Treaty addressed most of inconsistencies of the CFSP mechanisms and might impact EU sanction policy in the near future. The new treaty formally abolished the pillar structure, merged all general treaty provisions on external relations into one title and provided the EU with a single and express legal personality ${ }^{51}$. A single legal personality should reinforce the effectiveness and the legitimacy of the EU on the world scene. Henceforth, all external action, be it CFSP, trade or development, will be governed by the same general principles and objective, which again could have an impact on issues such as embargoes. ${ }^{52}$ The decision-making will however follow the "traditional" EU decisionmaking patterns: the Council will act by qualified majority with respect to agreements on most 'Community' matters, but by unanimity in CFSP affairs. ${ }^{53}$ The European Parliament

\footnotetext{
49 Fraser Cameron "What They Said: Fraser Cameron on CFSP, ESDP and the Balkans”, Europe, Issue 397, (June 2000)

50 George Parker, “EU team moots building foreign policy under one minister”, The Financial Times, (April 15, 2003)

${ }^{51}$ Jonas, 13

52 Jonas, 13

53 "The New EU Foreign Policy under the Treaty of Lisbon" in The Foreign Policy of the European Union: Assessing Europe's Role in the World, ed. by Federiga Bindi, Washington D.C.: Brookings Institution Press 2010), 46
} 
will be granted full co-decision rights and the Commission will lose its power of initiative in non-CFSP matters.

The representation is the major innovation introduced by the Lisbon Treaty and should bring much more consistency and cohesion to the EU foreign policy. To remedy the challenge of the brevity of the rotating Presidency, the Lisbon Treaty established the office of a permanent president of the European Council, appointed for two and a half years and replacing the rotating presidency at the level of the European Council. The President tasks include the chairing and preparation of European Council meetings and their follow-up.

The creation of the office of the European Union's High Representative for Foreign Affairs and Security Policy combines the responsibilities of the CFSP High Representative and the EU Commissioner for External Relations. The High Representative, currently Baroness Catherine Ashton, is also the Vice-President of the Commission ${ }^{54}$ The High Representative will act as the Union's single foreign policy chief, share agenda-setting capacities with member states (the Commission loses its right to initiative for CFSP matters)

This 'double-hatted' nature is the groundbreaking feature of the position. It is a bridge between former first and second pillar policies. With the 'Council hat', the High Representative chairs the Foreign Affairs Council and conduct the Union's foreign and security policy as mandated by the Council. With the 'Commission hat', the High Representative exercises the Commission's responsibilities in "external relations" and coordinate "other aspects of the Union's external action" such as development or trade policy. The High Representative will be appointed by the European Council, acting by qualified majority. The Commission President has to give his consent to the nomination. In addition, the high representative will be subject to the European Parliament's vote of

\footnotetext{
${ }^{54}$ Verola, 42
} 
approval. His term of office (normally five years) may be ended by the European Council, again acting by qualified majority. The Commission president may also request the high representative to resign. This request, however, has to be confirmed by a qualified majority in the European Council. Finally, the European Parliament can dismiss the Commission as a college, (de facto) including the high representative. ${ }^{55}$

The presence of the Union on the ground will now be reinforced: the Commission delegations became Union delegations and now carry a heavier workload, talking over some of the tasks previously handled by the rotating Presidencies. The Foreign Minister, currently Baroness Catherine Ashton will also have at her disposal a corps of Diplomats, called the European External Action Service, a team composed of officials from the Council the Commission and the Member States, to provide back-up and support to the High Representative, in conjunction with the diplomatic services of the Member States, in the implementation of the CFSP ${ }^{56}$.

Finally in the field of defense, The Lisbon extends crisis management tasks to areas such as disarmament and counterterrorism. A mutual assistance and a solidarity clause will be introduced into the EU treaties, the former relating to armed aggression, the latter to terrorist attacks and natural or man-made disasters. ${ }^{54}$ Furthermore, the treaties will provide for the first time for differentiation in the field of CSDP; notably by allowing that the execution of CSDP tasks may be entrusted to a group of member states (acting in association with the high representative), and by enabling a group of countries to enter into a 'permanent structured cooperation'. The Lisbon treaty

\footnotetext{
55 Jonas, 16

${ }^{56}$ European Parliament. “CFSP: Aims, Instruments and Achievements” , accessed November 13, 2010 http://www.europarl.europa.eu/parliament/expert/displayFtu.do?language=en\&id=74\&ftuId=FTU_6.1.1.html
} 
will also create the express legal bases for the (already existing) European Defence Agency and a start-up fund for CSDP operations.

We just reviewed the institutional set-up of CFSP, ESDP. "Unless a beautiful butterfly, the CFSP/ESDP is cumbersome and colorless and has great difficulty getting off the ground", summed up Dinan ${ }^{57}$. Given the divergence of member states' foreign and security policy interests and orientations and the weakness of CFSP instruments and mechanisms, the CFSP at the time of our study cannot be as formidable as its name implies. The case of the arms embargo illustrates this tension between supranational institutions and individual member states.

\subsection{Sanctions}

Our study analyzes the influences the Big Member States on sanction policy and reviews various arguments about the impact of sanctions on a country, in this case, China. We need to define sanctions, review the sanction literature and the EU record of its sanction policy

Sanctions are an instrument of a diplomatic or economic nature which seek to bring about a change in activities or policies such as violations of international law or human rights, or policies that do not respect the rule of law or democratic principles. ${ }^{58}$ Sanctions usually target the perpetrators of human rights abuses, who may be individuals, non-state actors, government elites or the military ${ }^{59}$. Analysts continue to ask: "Do sanctions work?" Much has been made of the failure of sanctions to deter late Iraqi President Saddam's efforts to acquire weapons of mass destruction and the devastating effects of those sanctions on the civilian population. On the other

\footnotetext{
${ }^{57}$ Dinan, 508.

${ }^{58}$ European Commission. "Sanctions or restrictive measures" http://ec.europa.eu/external_relations/cfsp/sanctions/index_en.htm

${ }^{59}$ Verification Research, Training and information Centre. "Verifying European Union arms embargoes". (Paper submitted to the United Nations Institute for Disarmament Research (UNDIR) for the European Commission project on "European Action on Small Arms, Light Weapons and Explosive Remnants of War”, 18 April 2005), 2
} 
hand, it is commonly accepted that economic sanctions contributed to bring down the South African apartheid regime and weakened Milosevic's Serbia ${ }^{60}$. Proponents of economic sanctions argue that sanctions can be as effective as military force and are more humane and that they are often an efficient instrument for achieving an important goal. $^{61}$ However, there has never been a clear consensus on the effectiveness of sanctions in the literature. The first major wave of research on the topic in the sixties and seventies argued that sanctions were not as effective as military force. A new wave of scholarship in the eighties, based on the utility of economic pressure argued that sanctions had been underrated by policymakers and scholars due to infamous fiascoes, such as the US embargo on Cuba.

The key evidence supporting such evidence was the study by Gary Hufbauer, Jeffrey Schott, and Kimberly Elliott (HSE), reviewing 115 cases of sanctions between 1914 and $1990^{62}$. The study reported success in 40 cases or 34\%. Pape however, after reviewing the HSE database and theory argues that economic sanctions did not achieve any major foreign policy goals and that the HSE is flawed (since most of the case were solved by direct or indirect use of force or do not qualify as economic sanctions). ${ }^{63}$ The persistent failure of sanctions suggests that states' reasons for employing them must lie somewhere else. Pape offers three hypotheses. First, economic sanctions should be most effective in disputes involving minor issues that do not affect the target country's territory, security, wealth or the regime's domestic security. Pape predicts, for instance, that an oil boycott of Libya would urge Colonel Qaddafi to surrender the men suspected of bombing Pan Am 103. Second, one might expect that economic sanctions would be

\footnotetext{
${ }^{60}$ Beverly Crawford. Review of Randall E. Newnham, Deutsche Mark Diplomacy: Economic Linkage in German-Russian Relations in Slavic Review, Vol. 63 no. 2 Summer 2004, pp. 427-28

${ }^{61}$ Robert Pape. "Why economic sanctions do not work”. International Security, Vol. 22, No2, (Fall 1997): 90136, 91.

${ }^{62}$ Gary Clyde Hufbauer et al.. Economic Sanctions Reconsidered: History and Current Policy (Washington, D.C.: Institute for International Economics, 1985), (Cambridge: MIT Press, 1985)

${ }^{63}$ Pape, 93
} 
more effective agents target states whose trade is completely on the coercer. Regarding this hypothesis, the evidence is not strong, the only available evidence being Lesotho conceding to South Africa's demands in 1983 and Nepal conceding to India's demands in $1989 .{ }^{64}$ Third, it is plausible that economic sanctions may be more effective against societies with extremely uneven income distributions than those with more income equality: that would explain the fall of the apartheid under the weight of sanctions and the strong resistance of Iraq to sanctions ${ }^{65}$. Pape argues that even if future research discovers under which conditions, economic sanctions can achieve foreign policy goals, sanctions might not be as liberal an alternative to military force as their advocates suggest. Economic sanctions often inflict significant human costs on the population of target states regardless of whether they ultimately succeed or fail (567,000 Iraqi children died due the UN embargo imposed on Iraq following the Gulf War while the war claimed a much smaller number of lives, 40,000$)^{66}$.

Shen argues that international economic sanctions can be effective as long as four criteria are met: the legitimacy of sanctions through international law or moral standards, the effect of the sanctions on the senders, the degree of international participation, and the sanctions' strength as a deterrent. ${ }^{67}$ Shen gives the example of the example of the sanctions against the apartheid in South Africa which fitted the 'profile'. The Apartheid regime violated human dignity and equality; the Universal Declaration on Human Rights was the legal and the moral reference against such violations; a majority of countries boycotted the South African government which made the sanctions deterrent. ${ }^{68}$ Shen gives a counter-example where all conditions were not met,

\footnotetext{
${ }^{64}$ Pape, 109

${ }^{65}$ Pape, 109

${ }^{66}$ Pape, 110

${ }^{67}$ Dingli Shen. “Can sanctions stop proliferation?”, The Washington Quarterly, 31:3 (Summer 2008): 89-100, 90

${ }^{68}$ Shen, 90
} 
such as the boycott of the 1980 Moscow Olympics, which did not affect the military involvement of the Soviet Union in Afghanistan.

Shen also reviews the evolving attitude of China regarding sanctions. The PRC does not generally support the concept, seeing it as an 'unacceptable approach' to resolving disputes. China believes that state sovereignty should not be violated in any shape or form. China did however adapt its position, reflecting its changed perspectives and interests. China denounced the abuses of the Apartheid regime based on human rights abuses and the fact that the antiapartheid movement was part of a larger independence and political liberation trend in Africa. China's views on sanctions are also shaped by its experience of the EU and the US embargo following the events at Tiananmen Square. Given the involvement of foreign powers in its domestic affairs in the case of the embargo, China tends to find international sanctions objectionable. The PRC believes that sanctions render nations unequal and tend to suppress less developed countries. ${ }^{69}$

To Hansen and Borchgrevink, the international support is the most important element to determine whether a sanction is going to be effective, as well as for McLean and Whang. ${ }^{70}$ McLean and Whang review the existing literature according to which without a sufficient level of international cooperation, the impact of economic sanctions will be limited and undermine the sanctioning state's abilities to obtained concessions from the targeted state ${ }^{71}$. Elliott goes further by saying that globalization brings about a greater flexibility for the targeted state as it can use alternative sources and trade with others and that a sanctioning state should take into account the target's ability to utilize these outside options. The sender might disregard these alternative

\footnotetext{
69 Shen, 98

${ }^{70}$ Elena McLean and Tahee Wang. "Friends and Foes? Major trading partners and the success of economic sanctions”. International Studies Quarterly (2010) 54: 427-447, 427

${ }^{71}$ McLean et al., 428
} 
providers available to the target only when the latter significantly depends on the sender's goods $^{72}$. McLean et al. focus on the international cooperation for the target instead of the sender, and argue that increasing trade for the sanctioned countries an indicator of international cooperation $^{73}$. The authors find that international support for economic sanctions is not the only factor that influences sanction effectiveness but also international assistance to the target. The sanctioner is considerably more likely to succeed in obtaining concessions from its target when the sanctioned country trading partners support the sanctioner's coercive action and decrease trade exchanges with the target. In our case, it is particularly relevant since the PRC imported weapons from other countries besides the US and the EU member states. Hansen and Borchgrevink illustrate their argument with the case of Norway which suspended aid to Ethiopia during the 1998-2000 war with Eritrea without international coordination, the aid suspensions did not have impact on the course of the war and seemed primarily motivated by domestic constraints. At the time, Norway had been lobbying for a seat at the Security Council and wished to demonstrate its concern for peace-building in Africa. ${ }^{74}$ The authors however show that other countries based their domestic factors explained policy choices towards Ethiopia based on domestic constraints: Germany cut its aid budget to Ethiopia against the advice of the German diplomats posted in Addis Ababa. They conclude by stating that the fact that countries make decisions largely for internal reasons shows that they have a few incentives for consulting with other countries and coordinating their decisions. This means that coordination is less likely, even though it is a necessary condition to make a sanction effective. ${ }^{75}$

\footnotetext{
${ }^{72}$ Kimberley Ann Elliott. “The sanctions glass: half full or completely empty?” International Security 23 (1): 50-65, 52

${ }^{73}$ McLean et al. 428

${ }^{74}$ Ketil Fred Hansen and Axel Borchgrevink. "Cutting aid to promote peace and democracy? Intentions and effectiveness of aid sanctions" The European Journal of Development Research, Vol. 18, No 4 (December 2006): 622-641, 637

${ }^{75}$ Hansen and Axel Borchgrevink, 638
} 
Baldwin offers an alternative explanation, arguing that the premises of the debate on sanction policies are false. Scholars and policy-makers need to clearly separate the question of whether sanctions are likely to work from that of whether sanctions should be used ${ }^{76}$. Answering one does not automatically provide an answer to the other. Second, the importance of costs must be acknowledged. Regardless of whether one is trying to determine the absolute utility of sanctions or their utility in comparison with alternative policy options, costs must be considered ${ }^{77}$. Third, the need for comparative evaluation of policy instruments must be acknowledged. The wisdom of using economic sanctions cannot be determined by studying the costs and benefits of sanctions in isolation from the costs and benefits of alternative techniques of statecraft such as military and diplomacy. Fourth, the complexity of 'success must be acknowledged: both literature on economic sanctions and military statecraft cannot use simplistic definitions of success that imply zero-sum games $^{, 78}$. In the context of German-Soviet relations, Newnham demonstrates that states can use economic power to gain political and security advantages in international relations, and to support arguments in favor of positive sanctions or "linkage." Newnham argues persuasively that positive sanctions succeed more often than negative sanctions because they are psychologically easier for the target state to accept, they have positive spillover effects on other aspects of the two states' relationship, they have a positive impact on groups within the target state, winning allies for the initiating state, and they offer little economic incentive for outsiders to work to break the sanctions. $^{79}$

Moore and Early in two different pieces explain the behavior of 'busting sanctions' states, or in other words, why some state would ignore a sanction on another country by continuing

\footnotetext{
${ }^{76}$ David Baldwin. "The Sanctions Debate and the Logic of Choice”, International Security, Vol. 24, No 3 (Winter 1999-2000): 80-107, 82

${ }^{77}$ Baldwin, 101

${ }^{78}$ Baldwin, 103

${ }^{79}$ Crawford, 428
} 
to trade ${ }^{80}$. Moore specifically looks into the application of arms embargoes. The use of embargoes has increased from two in 1990 to eleven by the end of 2006, despite fewer arms conflicts. ${ }^{81}$ The study of arms embargoes focuses on the behavior of the embargoed state and whether the weapons get through. Studies regarding the impact of the embargo on the sanctioned state showed that the achievement of policy goals was limited. ${ }^{82}$ The increasing use of arms embargoes as a policy makes the understanding of the motivations of the senders an important contribution to the literature, and the scholarship on sanctions busters and their motivations has been underdeveloped $^{83}$. Embargoes provide test cases of collective action problems and an opportunity to understand the causes of collective failure at the international level. Moore argues that states breach embargoes due to the benefits of arms exports and to advance their strategic interests. Embargoes create an incentive for violations by increasing the utility of an arms transfer from an exporting state. ${ }^{84}$ Moore shows that, first, exporters use arms as a form of influence to garner future concessions from the buyer and that, second, import dependence can be an indicator of similar political interests and political alignment. The current focus on the utility of arms embargoes as a tool of the international community to change the behavior of sanctioned countries ignore the benefits incurred by the exporting country. Early develops a measure to identify sanctions-busting behavior for a dataset covering 77 sanctions cases from 1950 to 1990 using liberal and realist explanations. Early uses the simple definition of an economic sanction by Askari et al. as "a restriction placed by a sender on commercial activities with the intent to inflict

\footnotetext{
${ }^{80}$ Matthew Moore. “Arming the embargoed: a supply-side understanding of arms embargo violations”. Journal of Conflict Resolution 54 (4): 593-615, 593

Early Bryan. "Sleeping with your friends' enemies: an explanation of sanctions-busting trade” International Studies Quarterly (2009) 53: 49-71, 49

${ }^{81}$ Moore, 593

${ }^{82}$ Moore, 594

${ }^{83}$ Early, 49

${ }^{84}$ Moore, 609
} 
economic losses on others.” ${ }^{85}$ This definition focuses on economic sanctions as a coercive policy tool used by a country against another, but the tool is not necessarily tied to the type of policy changes being sought. ${ }^{86}$ Early finds that the liberal theory provides a better account of sanctionsbusting, assuming that if the opportunity to sanction-bust arises, states would uniformly seek to exploit it. Early also finds that a sender state's closest allies are more likely to breach sanctions than its rivals. Finally, Early identified some predictors of sanction-busting among third parties and over which the senders have little control: the third party's GDP, trade openness and strong preexisting commercial relationship with the sanctioned state. ${ }^{87}$

Although there had not been an official EU sanction strategy till 2004, the EU has been implementing them since $1982^{88}$. Little attention has been given to EU sanctions in the literature and in those studies it is argued that 'if there is any European sanctions policy, it would be a preference to use positive rather than negative measures, or carrots over sticks ${ }^{89}$. There is no common agreement among researchers about the appropriate date of when to begin studying EU sanctioning policies, based on the legal and institutional developments of the EU: 1957 (Ginsberg 1989, 2001), 1970 (Nutall 1997), 1987 (Kalbermatter 1999, Hazelzet 2001) or 1992 (Anthony 1991, Edwards and Nutall 1994, de Vries and Hzelzet 2005). The early proponents support their argument based on Article 57 in the Treaty of Rome stating that 'any member state may take such measures as it considers necessary for the protection of the essential interests of its security, which are connected with the production of or trade in arms, munitions and war material... ${ }^{90}$ The EU does not like using the term 'sanction' and prefers the concept of "Restrictive Measures' due to an

\footnotetext{
${ }^{85}$ Askari Hossein et al. Economic sanctions: examining their philosophy and efficacy. Westport, Connecticut: Praeger, 84

${ }^{86}$ Early, 51

${ }^{87}$ Early, 67

${ }^{88}$ Joakim Kreutz. "Hard measures by a Soft Power? Sanctions Policy of the European Union 1981-2004”. Bonn International Center for Conversion, Paper 45, Bonn, 2005, 40.

${ }^{89}$ Kreutz (2005), p.3

${ }^{90}$ European Community. Treaty of Rome, March 25, 1957
} 
EU culture that focuses on incentives and multilateral approaches. ${ }^{91}$ Sanctions have certainly been frequently imposed, either on an autonomous EU basis or implementing binding Resolutions of the Security Council of the United Nations. The EU presented an official document on the use of sanctions in June 2004 entitled: "Basic Principles on the Use of Restrictive Measures" established an approach to sanctions as a useful foreign policy instrument, emphasizing their ability to maintain and restore peace and security in accordance to the principles of the UN Charter and the CFSP. It revolves around three principles: respect for international law (including the UN Charter), the physical security of EU territory (including promoting peace and international cooperation, and norms and values, such as democracy, human rights and fundamental freedoms. Those same three themes are the guiding principles of the ESDP, enunciated in the European Security Strategy. ${ }^{92}$ The Basic Principles on the Use of Restrictive Measures ${ }^{93}$ argue that the primary sanctioning actor is the UN, but that the EU is also willing to employ sanctions, preferably with broad international support. In the advent of EU sanctions, these should be considered part of a more comprehensive policy 'including political dialogue, incentives, conditionality, and could even involve, as a last resort, the use of coercive measures" ${ }^{\prime 94}$.

Since the mid 1990s, the EU made an effort to sanction in a 'smarter' way, targeting key actors to avoid effects on the civilian population. Smart sanctions include arms embargoes, travel bans and financial freezes, as well as prohibitions on trade in lucrative natural resources (timber, diamonds and oil is) ${ }^{95}$. Restrictions of admission have consisted of refusing individuals or groups, the right to enter the Union. The implementation depends on the immigration authorities of the

\footnotetext{
${ }^{91}$ Kreutz p.5

${ }^{92}$ Kreutz (2005), p.13

${ }^{93}$ European Union Council Secretariat. "Basic Principles on the Use of Restrictive Measures (Sanction)", Brussels, June 7, 2004

${ }^{94}$ European Commission. "Sanctions or restrictive measures"

http://ec.europa.eu/comm/external_relations/cfsp/sanctions/index.htm

${ }^{95}$ Vertic, .2
} 
member states. Diplomatic sanctions, sporting and cultural boycotts, and suspension of cooperation are largely symbolic measures traditionally employed by states to signal disapproval of other actor's behavior. There are very few examples of such. As mentioned earlier, the EU has managed to create approaches combining carrot and stick techniques through the programmatic use of suspending cooperation with third countries, such as in the conditionality clauses in trade arrangements $^{96}$.

The legal basis for EU sanctions depends on the exact nature and scope of the restrictive. Where Community action is required, a Common Position, defining the approach of the EU to a particular matter of a geographical or thematic nature must be adopted under Article 15 of the Treaty establishing the European Union. As an instrument of the CFSP, the adoption of a new Common Position requires unanimity from EU Member States in Council. If the Common Position provides for the reduction or interruption of economic relations with a third country, i.e. introduces economic and financial sanctions, implementation at Community level is governed by Article 301. Once it is adopted, the Member States must ensure that their national policies conform to the approach that has been established ${ }^{97}$.

In practice, it includes both embargoes on EU products and a ban on the import of products from the targeted country. Furthermore, the EU can restrict diplomatic contacts and instigate restrictions on the admission of individuals in EU territory. Once it is adopted, the Member States must ensure that their national policies conform to the approach that has been established. ${ }^{98}$. In these cases, the Commission is required to make a proposal for a Council Regulation, which the Council can adopt by a qualified majority: ${ }^{99}$ The Commission is then

\footnotetext{
${ }^{96}$ Bretheron Charlotte. and Vogler, J. The European Union as a Global Actor, (London: Routledge 1999), 47

${ }^{97}$ EU Commission "Sanctions"

98 European Union Commisssion. "Sanctions"

99 EU Commission "Sanctions"
} 
responsible for the implementation, since a sanction consists of a restriction on the common market where restrictive measures target persons, groups and entities which are not directly linked to the regime of a third country. However, when it comes to national security, Article 57 (currently Article 296) in the 1957 Treaty of Rome includes several restrictions on EU authority, including its legal ability to impose arms embargoes. A consequence of this is that the implementation of all arms embargoes is the responsibility of the individual member states. ${ }^{100}$ Although trade in manufactured goods falls under exclusive Community competence, issues regarding the member states' national security have been excluded from the common regulations. In this case, adoption of the Regulation by the Council requires unanimity and prior consultation of the European Parliament. Such is the case with arms embargoes. It is, therefore, common practice that arms embargoes are imposed by a Common Position and enforced on the basis of export control legislation of Member States (although the prohibitions on providing related financial or technical assistance are implemented through a Regulation). The Presidency or one of the Member States, usually assisted by the Council Secretariat, or the Commission, first prepares a proposal for a Common Position. This proposal is examined and discussed by the relevant Council groups, typically, the Council group responsible for relations with the third country concerned and, in all cases, the Foreign Relations Counselors Working Group (RELEX) and the Committee of Permanent Representatives (COREPER), which refers the Common Position proposal to Council for adoption. Following the adoption of the Common Position by Council, the text is published in the Official Journal of the European Union. ${ }^{101}$ Recent Common Positions related to particular arms embargoes have given more precise guidelines to the Member States on how the embargo should be implemented. The language used in recent Common Positions has made clear that restrictions

\footnotetext{
${ }^{100}$ Kreutz, .6

${ }^{101}$ European Union Council. "Sanctions"
} 
not only apply to physical items but also services of different kinds (such as technical training or assistance related to the provision, manufacture, maintenance or use of the items on the list).

The specific issue with arms embargoes becomes the reliability of individual states, and both the UN and the EU have had problems in ensuring compliance of their member states with embargoes $^{102}$. The forms of domestic measures to implement embargoes vary greatly from state to state. These measures can include primary legislation (Acts and Statutes), secondary or subordinate legislation (regulations), as well as administrative orders, decrees, government orders or rules ${ }^{103}$ and depend upon whether the state’s legal system is common law (Act), as in the United Kingdom (UK), or civil law, as in France and the Netherlands. EU member states refer to the 1996 Wassenaar Arrangement on Export Controls for Conventional Arms and Dual-Use Goods and Technologies for guidance on which equipment should be controlled through export control lists. However the Wassenaar list is only a minimal common standard which can be interpreted differently in national lists of controlled exports. The 1998 EU Code of Conduct on arms exports remedies these approximations and constitutes a modern version of the Common Criteria for arms exports adapted in 1991 and 1992 and covers the Common Military List of the European Union. The Code applies criteria against which member states must evaluate applications for export licenses by would be purchasers and outlines reporting procedures and mechanisms for intergovernmental denial notification and consultation. The evaluation of licenses takes into account respect for human rights in the applicant country and threats to peace by it. ${ }^{104}$ The EU reviews the performance by its member states against the Code’s criteria on an annual basis, and, quite comprehensively, public reports on the granting of export licenses to any country for military

\footnotetext{
${ }^{102}$ Sipri, 3

103 Sipri, 9

${ }^{104}$ Austin Greg. “The 1989 China Arms Ban: putting Europe’s position to Congress”. The Foreign policy Centre, (April 2005), 6
} 
related technologies are made annually both by the EU and member states. ${ }^{105}$ The Code was revised on the eve of enlarging to ten members and is regularly revised. In addition to the Review Process, the Conventional Arms Exports Working group (COARM) took additional decisions and made the EU member states agree that they will 'fully apply the Code of Conduct to license applications where it is understood that the goods are to be incorporated into products for reexports'.

Institutionally, the RELEX sanctions formation is in charge of monitoring and evaluating the technical implementation of arms embargoes and sanctions in general. The RELEX sanctions formation is a type of sub-committee where delegations discuss and compare sanctions of all kinds. In comparison, the Working Party on Conventional Arms Exports (COARM) is where delegations endeavor to harmonize their arms export policies on the basis of the 2000 EU Code of Conduct. ${ }^{106}$ The RELEX group provides the following on a regular basis: first, exchange of Information and experience between member states and with international organizations and third countries relating to the application of sanctions, breaches of sanctions and international sanctions; second, the evaluation of results and difficulties encountered in implementing sanctions, and third, development of good practice. In general, the RELEX group addresses horizontal issues (legal, administrative and so on) linked to the preparation and implementation of the decisions of the Council. ${ }^{107}$ The RELEX group specifically monitors activities in ancillary services, which include financial freezes; bans on technical assistance related to arms; bans on finances for the acquisition of arms; denials of export credit; and bans on equipment that could be used for internal repression.

\footnotetext{
${ }^{105}$ Eur-Lex, Official Journal of the European Union "Sixth Annual Report according to Operative Provision 8 of the European Union Code of Conduct on Arms Exports", (2004/C 316/01) 21 December 2004 and France, Ministry of Defense, Rapport au Parlement sur les Exportations d'Armement de la France en 2002 et 2003, 28 January 2005, http://www.defense.gouv.fr/portal_repository/817696033 0002/fichier/getData? \&ispopup=1. 
Unlike politically binding Common Positions that establish arms embargoes, legally binding Regulations establish the prohibition of ancillary services.

Regarding the China case, the arms embargo does not have a solid basis in EU law. As I said earlier, the embargo was declared before the creation for the CFSP. There has not been any decision to reform to revise the form of the embargo after 1989, and the form remains vague, unlike other embargoes decided post-1989 with strict guidelines and explicit Common Positions. It could be argued that there is no one arms embargo on China but a series of domestic arms embargo. In 1995 for instance, the United Kingdom government made clear that the embargo applied to weapons, and equipment which could be used for internal repression, license applications to export other defense articles and services as well as dual-use goods and technologies intended for military applications have been considered on a case-by-case basis in the light of the criteria that govern all defense exports. Under this policy, the UK export control authorities have approved exports of equipment with military applications—such as the Searchwater radar- to China. In the same fashion, in 1997, the then French minister for Defense, Charles Millon, observed that the embargo on equipment sales did not mean that no forms of military cooperation with China were possible. Under the policy adopted by France, it has been possible to export, for example, the AS-365N Dauphin-2 helicopter after the 1989 Declaration. The absence of a clear basis in EU law has created implementation and enforcement difficulties for a number of the countries that joined the EU in the latest round of enlargement. Several faced the possibility that exporters could question the basis for state decisions to deny export licenses to China. If faced with such questions, state authorities would not be able to make reference to any EU legislation or decision in explaining license denial. ${ }^{108}$

${ }^{108}$ Sipri, 12 


\subsection{Security}

The issue of the arms embargo brings up conflicting and complementary visions of security within the $\mathrm{EU}$, outside the $\mathrm{EU}$, in terms of the transatlantic relationship, the role of China and the balance of power in the Taiwan Strait.

The subject of security has been at the heart of the study of international relations for the past fifty years. Its political significance has been enormous during this period Security is a term widely used in both the analysis and the practice of international relations. Issues such as war and peace, the balance of power, arms race, arms control, and disarmament have been at the heart of the discipline of international relations. The beginning of a debate about security and perhaps its emergence as a contested concept are developments that only occurred in the early $1980 \mathrm{~s}^{109}$. "National security" signifies protection of the state’s people and territories against physical assault and in that narrow sense is equivalent to the term defense. But "national security" also implies protection, through a variety of means, of vital economic and political interests, the loss of which could threaten the fundamental values and vitality of the state ${ }^{110}$. Since power is widely distributed among the world's many actors and is of limited projectability, none of the participants is entirely sufficient; none is perfectly capable of fully satisfying its perceived security needs ${ }^{111}$. Therefore at one time or another, all have found it necessary to resort to one of several devices or approaches to compensate for state inadequacies. States then use collective security (League of Nations, UN), alliances and coalitions and international law at one time or another, sometimes simultaneously, to meet their perceived security needs or as means to advance domestic goals. Each approach can count both successes and failures in avoiding armed conflict.

\footnotetext{
109 Sheehan Michael. International security, (Boulder, London: Lynne Rienner Publishers , 2005),.2

110 Jordan Amos et al. American National Security, 5th edition. (Baltimore, London: John Hopkins University Press, 1999),.4

111 Amos, 15
} 
New thinking on security confirms the influence of different spheres. The Copenhagen School of international relations goes beyond the traditional state-centric focused definition in attempts (e.g.) to integrate economic, social and environmental threats, along with the political one $^{112}$. This school of thought moves down to the level of individual or human security, and then up in the other direction to the level of international or global security. Another school of thought has remained within a state-centric approach, but deployed diverse terms as modifiers to security in order to assess different forms of inter-state security co-operation. According to Karuse, however, these different approaches seem to confuse 'problems' and 'threats'. To the social scientist, the concept of security is an essentially contested one with multiple meanings and methodological, ontological, and epistemological underpinnings. The concept of security is linked to the concept of identity. To Ernest Gellener, identity is a multi-faceted phenomenon derived essentially from a Western conception of civilization. Identity is a 'more or less fluid, more or less constraining resource through which actors identify themselves, with its fluidity or constraints depending on the facts of history and societal opinions'. New identities emerge as potential rivals to the state generated outside its control, thus changing the nature of security in a wholly new context of political behavior ${ }^{113}$.

Comparative defense or national security policy cuts across such traditional divisions as international politics and economics and comparative and economic systems ${ }^{114}$. The first studies in the field were done in the early seventies by scholars such as Horton, Warner and Rogerson ${ }^{115}$. In 1975 and 1987, Baileys and others published comparative essays that examined the defense

\footnotetext{
${ }^{112}$ Cameron Ross, Perspectives on the Enlargement of the European Union, (Leiden: Brill 2002), 22

${ }^{113}$ Cameron, .31

${ }^{114}$ Murray Douglas and others. The Defense Policies of Nations: a comparative study, Third edition, 1994, (Baltimore: The Johns Hopkins University Press, 1994), p.7

${ }^{115}$ Horton Frank et al. (eds). Comparative Defense Policy, (Baltimore: Johns Hopkins University Press 1974)
} 
policies of the United States, the Soviet Union, China, the United Kingdom and France ${ }^{116}$. A related enterprise has been the study of comparative military-political sociology ${ }^{117}$. Some scholarly journals deal with comparative defense studies such as Armed Forces and Society, International Security, Defense Analysis and Comparative Strategy. Finally, credit must be given to works produced primarily in the 1950s and 1960s that examine military elites, particularly in the Third World, where they have been seen as agents of modernization and political development, but by others as obstacles to democracy. Murray builds upon these early studies to develop a methodology to study it $^{118}$. Several approaches to comparative defense studies can be taken. One is to select recurring issues such as military doctrine, force posture, the decision-making process, and weapons acquisition and then to compare and contrast how different countries deal with these issues. An alternative approach is to focus upon the budget ${ }^{119}$. Murray and Viotti chose a countrystudy approach on defense policy. This is a useful framework for the study at hand, where a country or an organizational approach for its foreign / defense policy on China is analyzed. Murray looks at four different parts: (1) the international environment as it is perceived by the state, (2) the particular state objectives, strategy and military force employment doctrine of that state. (3) The state's defense policy-making process: and (4) various recurring issues-force posture, the use of force, weapons acquisition, arms-control and civil-military relations.

The European Security arrangements have undergone a period of rapid transition since 1989. The demise of the Soviet Union, the unification of Germany, the movement towards a common foreign policy in the EU, and the triumph of western liberal democratic values have been

\footnotetext{
${ }^{116}$ Murray and others, p.8

117 Moskos Charles, Jr.. “The Military”. Annual Review of Sociology, Vol. 2, 1976 (1976), pp. 55-77, p.57

118 Murray et al., 9

${ }^{119}$ Wildawsky in Murray and others, 8
} 
much commented upon on both sides of the Atlantic ${ }^{120}$. Pagedas ${ }^{121}$ argues that between 1991 and 2000, Europe witnessed not only the end of the Soviet threat to Europe and its replacement by lower level, less intensive crises in the Balkans but also the sharp reduction of U.S. forces in Europe and Washington's reluctance to engage in European affairs militarily. But many of the certainties characterizing the Cold War were based on fragile underpinnings. There were tensions on both sides. On the Soviet side, Eastern European countries' economies demanded lots of attention from the Kremlin. On the Western side, there were tensions between Atlanticism and Europeanism and how the United States related to the Wet Europeans and vice and versa. All of those scars impact the current state of European security. Bipolarity has now given way to multipolarity and the fragmentation of the Eastern bloc has presented new problems for the EU. The EU's foreign policy project is unsettled in the sense that it lacks definitive goals.

The need to counterbalance an economic power with a political one is the main argument put forward by the proponents of a truly European common foreign, security and eventually defense policy. The European Union has steadily grown as an actor in international affairs, but its power and influence are predominantly of soft security argues Fraser ${ }^{122}$. 'Soft security' is basically looking at security in its widest context, that is, trying to promote democracy and the rule of law, protect minorities, and sustain economic development. The EU is by far the main provider of humanitarian assistance to the former republics of Yugoslavia and of economic aid to Russia, the countries of Central and Eastern Europe, and the Palestinians. That has been the focus of EU external policy over the last several years. Fraser argues that the EU has to move on from soft security to take part in hard security. That is at least partly a reflection of the fact that the EU is

\footnotetext{
${ }^{120}$ Cameron Ross, Perspectives on the Enlargement of the European Union, (Brill 2002), p. 42

${ }^{121}$ Constantine Pagedas (2001) "Post-Ismay Europe: Britain and the Rebalance of European Security", Mediterranean Quarterly, (12-4, 2001), 49

${ }^{122}$ Fraser Cameron, "What They Said: Fraser Cameron on CFSP, ESDP and the Balkans”, Europe, (Issue 397, (June 2000)
} 
much more credible as a commercial and economic power on the world stage than as a political player. There is a need for the EU to speak with a 'single voice'. It is in the Union's interest to create strategic space for itself in a world in which US strategies and tactics begin to seem very different from those that have been cultivated within the Union over time. An increasing disregard for European participation in strategic decisions that will affect Europe as well as the international system makes it harder to pursue European policies alongside the United States. American policy and its own shifting perceptions of its interests ${ }^{123}$ could become a major strategic restraint on the success of the ESDP if the Europeans do not manage "to negotiate their way through the rapids" with skill and speed, and also with the courage of their convictions. The 2003 European Union Security Doctrine ${ }^{124}$ was drawn up by Javier Solana following the Iraqi crisis to addresses the need for a more muscular foreign policy to deal with weapons of mass destruction, terrorism and the conflicts of the post-cold war era ${ }^{125}$. It is the first time in fifty-five years that the EU was able to draw up a common doctrine. The Big Three immediately endorsed the doctrine: Britain was anxious to deal with weapons of mass destruction, Germany strongly supported it because it was under an institutional umbrella, and France did so because the doctrine spelt how countries, including the US, could not act alone and expect to be effective. The ten candidate countries at the time, the which, for the majority, were pro-US, welcomed the doctrine because of the explicit support for the US and NATO. The doctrine specifies how the EU must put teeth on its traditional "soft power" tools of political, diplomatic and economic pressure. It also focuses on spending more on defense.

The creation of Western institutions such as the European Community and NATO was

\footnotetext{
123 Deighton Ann (2002) “The European Security and Defense Policy” Journal of Common Market Studies Vol.40, Number 4, (November 2002): 719-741, 721

${ }^{124}$ European Union Council “A Secure Europe in a better world, European Security Strategy”, Brussels, 12 December 2003, CFSP web site http://ue.eu.int/uedocs/cmsUpload/78367.pdf (2003)

125 Judy Dempsey "Big powers back more muscular foreign policy”, The Financial Times, June 12, 2003
} 
inspired by a notion of security that was both economic and military. The European Coal and Steel Community was created to bind France and Germany in an economic partnership and reduce the possibilities of a military conflict. NATO was also established to protect Western Europe from the Soviet Union. The security provided by the EU was facing inward, while the security provided by NATO was facing outward ${ }^{126}$. But both notions of security formation stress the importance of a 'border of order' provided by the two, which ran through the center of Europe, argue Fierke and Wiener. The 'iron curtain' represented a border of order for the EU and NATO, in so far as it played an important role in the process of identity formation for both organizations. Through political practice, NATO and EU member states have created a notion of belonging to a community with a particular order ${ }^{127}$. This order was built on liberal democratic principles that were, to a large extent, established and sustained by negative perception of the communist East. The collapse of the Soviet Union profoundly challenged the specific institutional identities. Enlargement was not simply a means to extend membership to member states from the other bloc; it also involved incorporating what was the 'Other'. During the Cold War, the self-definitions and normative ideals of both NATO and the EU were defined in the opposition to the East.

David Calleo envisions three pan-European models, ${ }^{128}$ projecting a different relationship between the EU and NATO in each case. In a bipolar Pan-Europe, the West claims its Cold war victories, and Western institutions enlarge; NATO and the EU include most of the CEECs, and financially helped a crippled Russia while keeping it under watch. In the second model, unified pan-Europe, the old East and West of Europe join to create a closely integrated Eurasian system. The EU and NATO extend eastward, and eventually embrace rather than exclude Russia. In the

\footnotetext{
${ }^{126}$ K.M. Fierke and Antje Wiener. “Constructing institutional interests: EU and NATO enlargement”, Journal of European Public Policy, Volume 6, Number 5, 2, (December 1999): 721-744, 726

${ }^{127}$ Fierke, et al.., 727

${ }^{128}$ David Calleo, Rethinking Europe’s Future, (Princeton: University Press 2001), 342
} 
third model, tripolar pan-Europe, the EU, Russia and the United States form three distinct but articulated poles. Each, while tied to the others, remains sufficiently distinct so as not to undermine its own cohesion. Neither the EU nor NATO becomes itself pan-European. Instead, each remains a critical Western element within a larger and looser pan-European superstructure. The EU for instance extends full membership only to Central and East European countries whose political economies are sufficiently convergent with the West to be absorbed successfully ${ }^{129}$. The EU does not imagine including Russia but nevertheless develops close economic relations with it, and also with former Soviet States. The US remains present in Pan-Europe through NATO but less as the ultimate guarantor of Western Europe against a resumption of Russian aggression or against an explosion of violence in the Near and Middle East. The US and Russia cultivate their common security interests in the Far East. NATO grows more European and less American-dominated, as the EU develops autonomous diplomatic and defense institutions, capable of acting effectively either inside or outside NATO. Russia does not actually join this more European NATO but cooperates closely with it through some overarching pan-European security structure ${ }^{130}$.

The tripolar pan-Europe model seems to fit the timeframe of our study (2003-2005) and afterwards. The case of the lift of the embargo shows a EU with increasing influence with some aspirations in Asia, the US, as involved as it is in Europe and in Asia, reluctant to see Europe trading weapons with China and finally Russia, though not included in our study, sharing the US mistrust of a closer relationship between the US and the EU. There are certainly several possible models of European security based on ideology, culture or vision of the world. The relationship between the ESDP and NATO is the best illustration of which actors should be involved and how defense and security policies within the EU should be led. The absence of a tradition of an

\footnotetext{
${ }^{129}$ Calleo, 342

${ }^{130}$ Calleo, 343
} 
independent European security structure combined with those ideological debates and the change in World Order affected the creation of European Union Security institutions. It seems there is a constant struggle of what European Security needs to achieve and how. Concretely, there are sharp differences over the ESDP-NATO relationship among France, Britain and Germany. True, the confluence of British and French foreign and defense policies have helped to create a European Security structure that promised to bridge the long-standing NATO-EU divide, but the proposals for a common defense before the Convention of Europe in November 2002 made by France, Germany and UK illustrated fundamental tensions over what kind of links ESDP should have with NATO. The proposals revealed the inherent ambiguities over the St Malo initiative launched by Britain and France in 1998. This was supposed to complement the EU's economic power with a defense and security arm. Instead, London saw it as an attempt to improve Europe's defense capabilities under the umbrella of NATO. Paris, on the other hand, saw it as an opportunity for the EU to develop its own security policy, with the US-led military alliance kept at a distance.

True, it is often argued that the enlargement of both the EU and NATO will bring strategic advantage but functional loss. ${ }^{131}$ There is a greater sense in having the two organizations with closely overlapping memberships, but that the practicalities of politics within these organizations will make them less manageable over time. However, a close membership overlap must overtime be the loss of one or other of these organizations, unless they become functionally different from each other. The revival of the Franco-German axis during the Iraqi crisis was a surprise, since, historically, defense is one of the rare topics where France and Germany have different conceptions $^{132}$. The 1963 Franco-German Treaty of Friendship (also known as the Elysée Treaty) strengthened the links between the two countries in terms of security and diplomacy. However, one

\footnotetext{
${ }^{131}$ Ann Deighton “The European Security and Defense Policy”, Journal of Common Market Studies, Vol.40, Number 4, (November 2002), 738

${ }^{132}$ Charles Grant, Ulrike Guerot. “A military plan to cut Europe in two”, The Financial Times, (April 17, 2003)
} 
of the French proposals brought up during the discussion was the creation of a European Defense Union, which was rejected by Germany, stating that the treaty should not affect Germany's commitments to NATO ${ }^{133}$. Similarly, when the French thought up the Eurocorps in 1992, they wanted it autonomous; but the Germans insisted on placing it in a NATO framework. When their security was at stake previously, the Germans always chose the US rather than France, though their overall policy was to be friends with both and a mediator between them. But the Iraqi crisis showed that Germany deliberately broke this historical pattern- and chose France over the US.

For the purpose of this study, security is defined as the protection of the Union's people and territories against physical assault and the protection, through a variety of means, of vital economic and political interests, the loss of which could threaten the fundamental values and vitality of the state ${ }^{134}$. The ESDP / CFSP is the enabler of this protection, using military and civilian assets for international conflict prevention and crisis management.

\subsection{Europeanization}

Europeanization is a key concept of our study and needs to be thoroughly reviewed. The concept started emerging in the nineties ${ }^{135}$. Within the political science literature, most of the authors define it as the interactions and impact of the EU on domestic actors and structures $^{136}$. Olsen lists several definitions of Europeanization: Europeanization as changes in external territorial boundaries, as the development of institutions of governance at the European level, Europeanization as the central penetration of state and sub state systems of

\footnotetext{
${ }^{133}$ European Navigator, multimedia digital library on the history of Europe, http://www.ena.lu/

134 Amos, 4

135 Jenny Fairbrass, “The Europeanization of business interest representation: UK and French firms compared”, Comparative European Politics, 1 (3) (2003) 313-334, 315

${ }^{136}$ Lee McGowan. "Europeanization unleashed and rebounding: assessing the modernization of EU cartel policy”, Journal of European Public Policy 12:6, (December 2005): pp 986-1004, p.996
} 
governance, Europeanization as exporting forms of political organization and governance that are typical and distinct for Europe beyond the European territory and finally, Europeanization as a political project aiming at a unified and politically stronger Europe ${ }^{137}$. Bulmer and Radaelli define Europeanization as a process consisting of a) construction b) diffusion and c) institutionalization of formal and informal rules, procedures, policy paradigms, styles, ways of doing things, and shared beliefs and norms which are first defined and consolidated in the EU policy process and then incorporated in the logic of domestic (national and sub national) discourse, political structures and public policies ${ }^{138}$. In the past few years, the concept has been applied to the study of an increasing range of EU activities. However, the concept is a contested one since there is a split between authors who perceive Europeanization as a process and those who see it as an outcome. The absence of agreement among scholars and a lack of consistent and systematic frameworks accounting for the varying patterns of adaptation across countries and sectors, makes testing Europeanization potentially problematic ${ }^{139}$. Clearly, at the very least, there are analytical difficulties in separating 'cause' from 'effect' as well as risks of confusing Europeanization with 'European Integration $^{140}$. European Integration focuses on what happens to the state and its sovereignty whereas Europeanization analyzes what happens to domestic institutions and actors ${ }^{141}$.

\footnotetext{
${ }^{137}$ Johan Olsen. "The many faces of Europeanization”, Arena Working Papers WP 1/2, Center of European Studies, University of Oslo, (2002), pp.2-3

${ }^{138}$ Bulmer Simon and Claudio Radaelli. "The Europeanization of National Policy”. Queen’s Papers on Europeanization, No1 / 2004, 4

${ }^{139}$ Knill Christoph and Dick Lehmkuhl. "How Europe matters: different mechanisms of Europeanization, European Integration online Papers (EIoP), Vol. 3, No. 7, (June 15, 1999), 3

${ }^{140}$ Fairbrass,.317

${ }^{141}$ Börzel Tanja. "Pace-Setting, Foot-Dragging, and Fence-Sitting: Member States Response to

Europeanization”, Journal of Common Market Studies Volume 40, Number 2 (2002), pp.193-214
} 
Europeanization is just one mechanism within the broader construct of European integration $^{142}$.

The effects of Europeanization are also widely debated in the literature. Rather than talking about effects and causes, Hitz and Goetz distinguish between direct and indirect impacts of Europeanization $^{143}$. Direct impacts are outcomes that require domestic policies to be changed to conform to new European-wide norms ${ }^{144}$. For example, the regulatory regime has forced the liberalization of domestic markets. To them, the indirect impact of European governance is more interesting. The creation of planning authorities at the regional level produces in turn demands for a democratization of these requested structures, and hence the creation of elected regional assemblies and governments ${ }^{145}$. Those outcomes either reinforce existing trends or serve as catalysts for reforms. When member states already have regional authorities (such as Italy or France), EU regional policies have reinforced their demands for further delegation of policy competences away from central government. In contrast, when there are no such regional institutions, the EU acts as a catalyst in creating such institutions ${ }^{146}$. Scholars refined the concept of impacts by saying that Europeanization is a two-way process in which member states governments both shape European policy outcomes and adapt to them. The top-down approach refers to how member states respond to a growing European impact on their domestic level of

\footnotetext{
${ }^{142}$ Schmidt Vivien. "Europeanization and the mechanics of economics policy adjustment”. Journal of European Public Policy 9:6 (December 2002): 894-912, 909 and also

Major Claudia. "Europeanization and Foreign and Security Policy_Undermining or Rescuing the Nation State?” Politics: 2005, Vol. 25 (3): .175-190, 178

${ }^{143}$ Hix Simon and Goetz Klaus. "Introduction: European Integration and National Political Systems” in Europeanized Politics? European Integration and National Political Systems edited by Goetz Klaus, Hix Simon, pp 1-26 (Frank Cass Publishers 2001), 10

${ }^{144}$ Hix and Goetz, ibid.

${ }^{145}$ Hix and Goetz, op. cit., 11

${ }^{146}$ Hix and Goetz, ibid.
} 
policy ${ }^{147}$. The top-down studies consider 'the consequences for national structures, policy-making and outcomes that result from the development of institutions and policies at the EU level ${ }^{148}$.

The "bottom-up” refers to how successfully a state 'uploads' its institutional models, policy preferences and 'ways of doing things' to the $\mathrm{EU}$ level ${ }^{149}$. Uploading is also a way to minimize the costs, which the implementation of European norms and rules may impose on member states' constituencies. Therefore, member states have an incentive to upload their domestic policies to the European level in order to minimize the costs of EU adaptation ${ }^{150}$. Member states seek to shape European policy-making according to their interests and institutional traditions ${ }^{151}$. Uploading may also enable state governments to address problems, which preoccupy their constituencies but can no longer be dealt with effectively at the domestic level (e.g. organized crime, environmental pollution) ${ }^{152}$.

Tanja Börzel recognizes three kinds of reactions from the member states to Europeanization: pace-setting, foot-dragging and fence-sitting ${ }^{153}$. Pace-setting means that Member States actively push policies at the European level, reflecting policy preferences and minimal implementation costs. Downloading would then create fewer problems for the pace-setter, who can easily incorporate it into existing arrangements. Pace-setting not only presupposes established domestic policies but also the capacity to push them through the European negotiation process, very often against the opposition of other member States with diverging policy preferences. To the contrary, foot-draggers block or delay costly policies in order to prevent them altogether or to

\footnotetext{
${ }^{147}$ McGowan, 996 and Major, .179

${ }^{148}$ McGowan, 99

149 Major, 177

150 Börzel,.212

${ }^{151}$ Heritier A. 'Leaders' and 'Laggards' in European Clean Air Policy” in Unger B. and F.V. Waarden (eds) Convergence or Diversity? Internationalization and Economic Policy Response, (Aldershot: Avebury Studies in Green Research, 1994), p.278

152 Börzel, 196

153 Börzel, 196
} 
achieve at least some compensation for implementation costs. The foot-draggers usually show a poor level of compliance ${ }^{154}$. The fence-setter is a neither-nor: neither systematically pushing policies nor trying to block them at the European level but building tactical coalitions with both pace-setters and foot-draggers ${ }^{155}$. Fence-setters tend to take an indifferent and neutral position, or they build changing coalitions with pace-setters and foot-draggers, depending on the issue involved. ${ }^{156}$ Börzel's theory applies well to our case. The issue with the EU China policy is that the relationships started prior the EC. Most of the policies emanated from Member States themselves, especially the big ones. There might be then some leadership on policy initiatives and policy formulation based on the density of the relationship but also some reluctance to see adopt a policy which might be contrary to a Member State’s interests.

Very few studies applied the concept of Europeanization to foreign policy. Europeanization has been mainly used for first pillar policies (pre-Lisbon or also called community method post Lisbon) as an interactive, ongoing and mutually constitutive process of ‘Europeanizing’ and 'Europeanized countries, linking national and European levels ${ }^{157}$. As mentioned earlier, foreign policy is mainly intergovernmental, governed by treaties not legislation. It is then more challenging methodologically to measure EU impact on the state level since these processes are not as clearly detectable in the second pillar as they are in the first pillar. "Coordination generating EU input and domestic change” exists, but when compared with the level of institutionalized integration evident in the first pillar, it is rather weak. Major argues then that there is a risk of overestimating Europeanization as an 'all explaining factor',

\footnotetext{
154 Börzel, 203

155 Börzel, 194

156 Börzel, 206

${ }^{157}$ Major (2005), 176
} 
neglecting the importance of other domestic and international spheres ${ }^{158}$. Due to those methodological challenges, Europeanization of foreign and security policy is less a clear-cut domestic adaptation and more a gradual transformation. The lack of supranationalism in EU foreign policy leads to a 'horizontal pattern of Europeanization' marked by an exchange between governments and the resultant learning of shared policy principles' as opposed to the hierarchical vertical governance usual in first pillar policy areas ${ }^{159}$. Europeanization can be considered a learning process about good policy practice for elites for which the EU sets the scene, offering a forum for discussion and a platform for policy transfer ${ }^{, 160}$. The idea of cross-loading refers to these horizontal patterns and socialization as mechanisms of Europeanization in foreign and security policy. Domestic change might not only be generated at the EU level but might come indirectly through the transfer of ideas and norms form European neighbors, domestic entities. Bulmer and Radaelli remind that national governments are the key actors, where the policy process is not subject to European law. It does not mean that Europeanization does not take place but it means that it is much more voluntary ${ }^{161}$ and non-hierarchical. When member states cannot reach an agreement such as during the Iraqi crisis, the policy is not Europeanized. On the other hand, if there is an exchange of practice, leading to 'cross-fertilization' of idea and learning, there is Europeanization, for instance in the case of the Palestinian issue ${ }^{162}$. Ben Tonra defines Europeanization in foreign policy as”... a transformation in the way in which national foreign policies are constructed, in the ways in which professional roles are defined and pursued and in the consequent internalization of norms and expectations arising form a complex system of

\footnotetext{
${ }^{158}$ Major (2005), 183

${ }^{159}$ Major (2005), 186

${ }^{160}$ Bulmer and Radaelli (2004), 12

161 Tonra Ben. "The Europeanisation of national foreign policy: Dutch, Danish and Irish foreign policy in the European Union”, (Aldershot: Ashgate, 2001)

162 Major (2005), 186
} 
collective European policy making”"163. This 'transformation' usually translates as adaptation to EU norms and standards, an 'incremental process orienting Member States' politics and policies towards the EU. Wong argues that the weight of the acquis of EPC/CFSP/CESDP should increasingly have some impact on the foreign policies of the EU states, leading to convergence of foreign policies towards China ${ }^{164}$.

Three examples of Europeanization applied to foreign policy illustrate these theoretical challenges. In his book 'Europeanization of British Defense Policy”165, Robert Dover argues that European security and defense integration can be best explained in liberal intergovernmentalist terms. Dover conceptualizes Europeanization as a process whereby EU member states upload their state preferences to the European level. This process occurs either 'formally' when supranational provisions become codified at intergovernmental conferences (IGCs or 'informally' in the formulation of day-to-day EU politics). Dover's study is based on fifty elite interviews. Dover argues that the initial definition and adoption of the ESDP reflected core British defense preferences. Thus Dover points out that from 1997 onwards the Europeanization of British defense policy was part of a deliberate strategy, developed and implemented by a small group of officials and politicians under the aegis of Premier Blair, which aimed at ensuring a continued US engagement in the European security architecture and a strengthening of the pan-European military capabilities following the Kosovo debacle’. ${ }^{166}$

The British government was successful in invoking political, military and economic power during the Anglo-French Saint Malo negotiations and several subsequent bilateral

\footnotetext{
163 Tonra (2001), 229

${ }^{164}$ Wong (2005), 1

165 Robert Dover. Europeanization of British Defence Policy, (Burlington, VT.: Ashgate, 2007)

${ }^{166}$ Gaspers Jan. 'Europeanization of British Defence Policy by R. Dover'
} 
negotiations with French and German officials, as well as the 2000 Nice IGC to impose its preferences. However, Dover shows that past attempts to upload British preferences have not been always successful and even harmed further Europeanization through the case of Iraq. Dover also examines the acceleration of the Europeanization of arms production and trade in recent years (see chapter 4).

Another case involving the UK shows how a Member State this time drew upon its increasingly close relationship with the EU to supplement its own bilateral (an other multilateral) efforts to achieve its foreign policy objectives ${ }^{167}$. It may qualify as an example of convergence. In the case of Zimbabwe, Britain used the EU as a mechanism to advance state interests and the promotion of human rights. Britain certainly took some bilateral initiatives, including attempts to bring ZANU-PF delegations to London, but involved the EU and other international organizations to impose targeted sanctions. The outcome has been a strong signal sent to President Mugabe and showed a high degree of convergence between the British government and the EU. Both the EU and Britain promote good, liberal governance within Zimbabwe.

Finally, Irondelle brings up a scenario where Europeanization occurred without the European Union. Irondelle analyses the impact of European integration on the transformation of the French military policy between 1991 and $1996^{168}$. Irondelle shows that the integration of the French military occurred without the European Union. The French elites and indirect pressures led to the reform of the military. French elites wanted a development of the

\footnotetext{
${ }^{167}$ Williams Paul. "The Europeanization of British Foreign Policy and the Crisis in Zimbabwe”, paper presented at the European Foreign Policy Unit workshop on 'Europeanisation of national foreign policies' London School of Economics, 5 June 5, 2002

${ }^{168}$ Irondelle Bastien. (2001) "Europeanization without European Union? French military reforms 1991-1996" . (In European Union Studies Association (EUSA) Biennial Conference 2001 (7th), May 31-June 2, 2001), Madison, Wisconsin, 209
} 
European defense and the 1996 reform was presented as a response to the European integration challenge. Jacques Chirac declared at the time that 'the European ambition affects first and foremost, our conventional forces'. ${ }^{169}$ However, the Europeanization of French military policy was paradoxical since defense was the least integrated of European policies in 1996 and France had implemented the most independent and nationalist military policies within the EU, following a Gaullist tradition. In his case study, Irondelle analyses the military reforms laid out in the 1994 Livre Blanc sur la Defense (White Paper on Defence) and bases his analysis on the consultation of official and unofficial documents from working groups on the topic and hundred of confidential interviews with French policy-makers and high-ranking officials. Irondelle concludes that there has been a Europeanization in the transformation of the French military in a normative way and not from a top-down perspective proved by the non existence of a common European Security Defense Policy at the time (between 1991 and 1996). But it qualifies as an example indirect adaptation pressure to conform in advance to EU standards

To conclude, the issue raised is not what Europeanization is but how the term can be useful for understanding the dynamics of the evolving European polity. That might help scholars to give better accounts of the emergence, developments and impacts of a European, institutionallyordered system of governance. Olsen argues that the different conceptions of Europeanization complement, rather than exclude each other. Olsen acknowledges that despite the empirical complexity and conceptual confusion, scholars need to double their efforts in modeling the dynamics of European change. One of 'the immediate challenges is to develop partial, middlerange theoretical approaches that emphasize domains of application or scope conditions and that are empirically testable. A long-term challenge is to provide a better understanding of how

${ }^{169}$ Irondelle Bastien., .209 
different processes of change interact and make institutions co-evolve through mutual adaptation'. ${ }^{170}$ Bulmer and Radaelli explain the fact that Europeanization is a popular topic of research because it is a model-building exercise ${ }^{171}$.

\subsection{Policy Convergence}

Policy convergence is a central concept in comparative public policy and closely linked to Europeanization. Many studies emphasize the development of similar policies across countries over time ${ }^{172}$. Knill argues that the booming research on globalization and Europeanization affects the current research on convergence. 'Does the strong growth of economic and institutional interlinkages between nation states lead to increasingly similar policies across countries? Or is the search for convergence emerging from the domestic impact of globalization and European integration, as domestic responses to global or European challenges are strongly influenced by existing domestic structures and institutions ${ }^{173}$ ? The accepted definition of policy convergence is read as 'the tendency of societies to grow more alike, to develop similarities in structures, processes and performances, ${ }^{174}$. The literature on convergence and its related concepts offers a broad range of causal factors in order to explain changes in the similarity of policies across countries: first, the result of similar but independent responses of different countries to parallel problem pressure; second the imposition of policies (from international organizations), third harmonization of national policies through international or supranational law, fourth, regulatory

\footnotetext{
${ }^{170}$ Johan Olsen. "The many faces of Europeanization”, Arena Working Papers WP 1/2, Center of European Studies, University of Oslo, (2002), pp.2-3

${ }^{171}$ Simon Bulmer and Claudio Radaelli. “The Europeanization of National Policy” Queen's Papers on Europeanization, no1 (2004), 4

${ }^{172}$ Knill Christoph and Kathrina Holzinger. "Cause and conditions of cross-national policy convergence”, Journal of European Public Policy 12:5 (October 2005): 775-796, p.775

${ }^{173}$ Introduction: cross-national policy convergence: concepts, approaches and explanatory factors, Journal of European Public Policy, (Oct2005), Vol. 12 Issue 5, p764-774, p.764

${ }^{174}$ Knill, 765
} 
competition emerging from the increasing economic integration of European and global markets, finally, by transnational communication ${ }^{175}$. Knill also points out that there are facilitating factors leading to convergence in terms of similarities between states, level of institutional similarity, cultural and socio-economic similarities, and also the terms of the policy at stake: policies involving high distributional conflicts among domestic actor coalitions will diffuse and hence converge to a lesser extent that regulatory policies with comparatively small redistribution consequences $^{176}$.

Some argue that there has been 'no significant convergence towards a common institutional model, homogenizing the domestic structures of the European states ${ }^{177}$. Europeanization does not mean a homogenization across boundaries, since varying state political and cultural structures lead to different adaptations. Schmidt warns against the temptation to believe that European Member States are all converging towards a single EU regime. European policies have tended to follow domestic policies changes as much as lead them, with national policies having shaped those of the EU as often as EU policies have shaped those of the Member States. Especially when it comes to economic policies, adjustments are state specific and 'path dependent'. Member States have responded to the pressures of Europeanization at different times, to different degrees, with different results argues Schmidt. ${ }^{178}$ Schmidt proposes to look at adjustment pressures and mechanisms related to EU decisions: it includes vulnerability to global and economic forces, and political institutional capacity to alter their policies and policy-making institutions as necessary, the extent to which the proposed policies went against their policy

\footnotetext{
${ }^{175}$ Knill, 769

${ }^{176}$ Knill, 771

177 Olsen, 15

${ }^{178}$ Schmidt, 895
} 
legacies and preferences, and the discourse that may have enhanced their capacity to respond by changing perceptions of vulnerabilities and legacies and, ultimately, therefore, preferences.

The enlargement literature seems however to show the opposite, arguing that membership in the EU has led to the gradual transformation of nation-states from 'autonomous actors in the international sphere to embedded actors within regional networks of exchange ${ }^{179}$. Those states undergo a process of transformation in which they adapt their domestic institutions and policies to meet the EU requirements of membership.

Such convergence can be observed in more regionalization, more flexibility, strong sectorization and high administrative coordination ${ }^{180}$. The most common approach that best fits the new entrants is convergence for various reasons. First, since the democratic transition, post-communist countries have undergone an 'imitative transformation', emulating Western market economies. Second, the simultaneity of transformation in coping with the EU requirements exerts high adaptation pressures on applicant countries. Third, the EU has a strong bargaining position in the accession process, imposing EU rules and standards. It forces the candidate countries to comply with the 'acquis' without a say in its negotiation ${ }^{181}$. It goes back the to the main methodological challenges of our study: applying Europeanization to foreign policy and dealing with a EU policy with a non-EU member which started after the relationship among Member States and that non-EU member. In other words, might we expect convergence in initiatives launched after 1975 (when the European

\footnotetext{
179 John Glenn, "From Nation-States to Member States: Accession Negotiations as an Instrument of Europeanization”, Comparative European Politics 3-28, (2004), 4

${ }^{180}$ Rometsch and Wolfgang Wessels, eds. "The European Union Irondelle Bastien. (2001) "Europeanization without European Union? French military reforms 1991-1996" . (In European Union Studies Association (EUSA) Biennial Conference 2001 (7th), May 31-June 2, 2001), Madison, Wisconsin, 209n and Member States: towards Institutional Fusion?”, European Policy Research Unit Series, (Manchester :University Press 1996), 329

${ }^{181}$ Grabbe Heather, "How does Europeanization affect CEE governance? Conditionality, Diffusion and Diversity, Journal of European Public Policy Vole 8, Issue 4, (December 2001): 1013-1031, 1015
} 
Community started working with the PRC) or a conflict between existing bilateral agreements (Member States-China) with EU-China agreements? Our next section looks into this issue of adaptation and compliance.

Wong gives an interesting response: the impact of EU institutions on state foreign policy behavior towards China was more significant than was commonly imagined or admitted. Wong compared the positions of France, Britain, Germany and the Commission on China in the three issue-areas of economics, political-strategic interests and human rights and found that there was a more coordinated position on China in 2003 compared to 1985 in those three areas. The policies of the three counties had undergone a significant level of convergence ${ }^{182}$. Wong argued that convergence happened by default rather than design. First, Europe's influence in China had been on a steady and rapid decline after 1945. "On military and political issues, only Britain and France have had some residual diplomatic influence in the 'grandes negociations politiques' (major political negotiations) ${ }^{183}$. Second, the EU's role and presence in East Asia had grown, in contrast to the diminishing profiles of individual member states and former colonial powers. From 1991, France and Britain were unable to act as individual actors in there own right (witness their failure to obtain separate seats in the ASEAN Regional Forum $)^{184}$. One may argue that the EU policy toward China had been 'Germanized' in that Germany has succeeded in exporting its model of discreet diplomacy, change through trade and non confrontation on human rights to the EU level. In other words, Germany had 'Europeanized' what was originally a member state's national policy in the political-diplomatic field.

\footnotetext{
${ }^{182}$ Wong Reuben (2005), 17

${ }^{183}$ Wong Reuben (2005), 17

${ }^{184}$ Ibid. p.17
} 


\subsection{Adaptation and policy misfits.}

We just reviewed different kinds of Europeanization. There has been some research about compliance and how well Member States adapt to EU law. The research focuses o on domestic areas. In Transforming Europe: Europeanization and Domestic Chang, Cowles, Caporaso and Risse explore the impact of European institutions on the domestic structures of the member states by reviewing ten different issue areas ${ }^{185}$. The impacts of Europeanization have varied across countries, because policy regimes and structural arrangements vary across national cultures and issues. $^{186}$. The authors found that all countries, including the big ones, encounter adaptational pressures due to policy or structural incompatibility with the EU. The findings suggest that structural convergence (convergence of basic domestic institutions) is modest as opposed to policy convergence which takes place more frequently. Member States have leeway on how to implement a particular objective. An example is EMU which has led to similar central bank statutes but has not yet produced real convergence in fiscal policy.

One intriguing finding of the book is that partial convergence is taking place even in situations where the EU does not dictate any targets or end goals. All member states engage in some learning and tend to appropriate arrangements that seem to guarantee a good fit with the EU goals. ${ }^{187}$

It is worth describing thoroughly the Cowles et al. model since I will use its basic premises as part of my methodology. Cowles et al. built a three-step approach model to predict how a country would respond to a new EU policy. ${ }^{188}$ First, they identify the relevant

\footnotetext{
${ }^{185}$ Kurzer Paulette “Review: Comparative views of Europe”, International Studies Review, Vol. 4, No. 1 (Spring, 2002), pp. 182-186, 184

186 Kurzer, 186

187 Kurzer, 186

${ }^{188}$ Maria Green Cowles et al. Transforming Europe: Europeanization and Domestic Change. (Ithaca, NY: Cornell University Press, 2001)
} 
Europeanization processes, formal and informal, norms, rules, regulations, procedures at the European level ${ }^{189}$. The second step in the framework is to identify the "goodness of fit' between the Europeanization processes and the institutional setting, in other words between what Europeanization of China policy entails and the institutional setting of the member state. The degree of 'fit' constitutes what the authors call 'adaptational pressures'. In principle the degree of adaptational pressures determines the extent to which domestic institutions would have to change in order to comply with European rules and policies. ${ }^{, 190}$ The lower the compatibility fit between European institutions and national institutions, the higher the adaptational pressures. Based on different political, economic legal and societal institutional systems, the degree of adaptational pressures varies according to member states. European rules can be easily incorporated because they match the domestic system of rules and regulations or because the member states changed their settings before the setup of those rule, which corresponds to the case of export regulations for weapons systems for instance. In other cases, European norms and practices ran completely counter to national rules, practices and administrative traditions. Finally, the degree of adaptational pressures also varies based on the perception of the role of nation states within the process of European integration.

Finally, the third piece of the framework is the mediating institutions and actors' practices to account for domestic change. The authors identify a series of mediating factors which will determine adaptation or convergence:

1. Veto points in the domestic structure. The existence of veto points has been identified as a major factor preventing structural adaptation. The more power is dispersed across the political system and the more actors have a say in political decision making, the more

\footnotetext{
${ }^{189}$ Cowles et al. 6

${ }^{190}$ Cowles et al., 7
} 
difficult is to foster the domestic consensus or 'winning coalition' necessary to introduce institutional changes in response to Europeanization pressures. For example, multiple veto points in the Italian political system blocked the country's structural adaptation to Europeanization pressures in transportation policies. ${ }^{191}$

2. Mediating formal institutions provide actors with material and ideational resources to bring structural change. For instance, the British Equal Opportunities Commission was crucial in providing women's organizations with the means to use EU equal Pay and Equal Treatment Directives in furthering gender quality. Multiple veto points and facilitating institutions exert their effects on the capacity if actors to induce change in opposite directions. ${ }^{192}$

3. A country's organizational and policymaking cultures also affects whether domestic actors can use adaptational pressures emanating from Europeanization to induce structural change. A culture based on consensus for example would overcome veto points.

4. The differential empowerment of domestic actors and learning: Structural changes lead to retribution of power capacities among the relevant actors in a political, social and economic system. Milner and Rogowski argue that exposure to international trade and increased economic interdependence leads to a shift in societal interest coalitions in favor of export-oriented sectors. More generally, Cowles et al. argue that Europeanization leads to a redistribution of power among whole range of actors: legislatures, courts, regional governments to interest groups and companies. ${ }^{193}$

5. Learning: Differential empowerment enables actors to further given interests and

\footnotetext{
${ }^{191}$ Cowles et al., 9

${ }^{192}$ Cowles et al., 10

${ }^{193}$ Cowles et al., 11
} 
to induce structural change. Learning that results in change of actors' interests and identities occurs rather rarely ${ }^{194}$. Elite learning however occurs especially when there have been critical policy failures or in perceived crises when actors reassess their set of preferences.

The authors expect structural change in response to Europeanization to occur if and when a) it generates significant adaptational pressures in the domestic environment: and b) facilitating factors are present, enabling actors to induce or push through institutional change.

The model would be applicable to our study as long as we identify different factors. I will explain in the methodology section which factors might be suitable to predict adaptation or convergence between EU sanction policy and the Member states.. situation.

Falkner et al. identify misfit between EU demands (application of directives in that case) and member states as the main explanatory factor for implementation performance in much of the Europeanization literature. The adapation to a EU directive should be smooth if it entails only small changes at the domestic level. ${ }^{195} \mathrm{~A}$ directive will be difficult to implement if significant adjustment is necessary in the domestic structures. Falkner et al. recognize however the methodological challenge of having to conceptualize potential misfits in such terms as to allow a direct comparison to be made between countries, and even between different policies.

The authors argue that the misfit can be either substantive, i.e. content and policy related, or be an issue of procedure. The misfit means that EU law differs from domestic law gradually (the example of the duration of parental leave) or substantially (e.g. no parental leave). Europeanization would be then either quantitative (strengthening or weakening of an existing policy) or qualitative (creation of a policy). A high degree of misfit in the polity would

\footnotetext{
${ }^{194}$ Cowles et al., 12

195 Gerda Falkner et al. Complying with Europe: EU Harmonization and Soft law in the Member States (Cambridge: University Press 2005), 27
} 
occur when a crucial domestic institution is challenged ${ }^{196}$. Falkner et al.’s study applies to social policy but seems suitable for our case. Member States had some rules as for the procurement of weapons prior the 1989 embargo (existing policy) and the embargo was in some cases not as rigorous as the domestic legislations. The cancellation of the policy and the possible replacement by an upgrade of the Code of Conduct on Weapons sales represents an innovation on the EU part.

\subsection{Methodology}

\subsubsection{Introduction}

To analyze the case of the lift of the arms embargo between 2003 and 2005, and to measure the influence of Britain, France and Germany on the European Union China policy, the study combines a questionnaire on China policy and sanction policy addressed to defense and foreign affairs officials from the three member states and EU officials, press articles, interviews and speeches from that period, the application of Tanja Börzel's theory, who recognizes three kinds of reactions from the member states to Europeanization: pace-setting, foot-dragging and fence-sitting and finally the application of Cowles Caporaso Risse model to understand the responses of Europeanization and explain the goodness of fit between the three Member States and the EU policy.

\subsubsection{The Questionnaire and the Interviews}

A questionnaire on China policy and sanction policy addressed to defense and foreign affairs officials from the three member states and EU officials was created. The questionnaire was divided in four parts: general questions about the embargo, institutional questions about the role of the EU institutions, role of EU member states in the debate, influence of the Big

\footnotetext{
${ }^{196}$ Falkner, 32
} 
Three, impact of the bilateral relations and finally the perception of the place of China in the international security sphere. The time frame is the 2003 to 2005 period, which corresponds to the time of the debate on the lift of the arms embargo. The questionnaire was a useful tool for data collection but above all an opportunity to lead a discussion. I understood that the success of hearing back from busy government officials was slim but I wanted to guarantee some sort of answer at minimum to an interview at best. To contact the respondents, I sent an email to see whether we could set up a meeting to discuss the issue and go over the questionnaire. An interview allowed a more open discussion and could include 'off the record' comments. If the addressees were too busy, they might send some information about the issue (speeches, press articles) or redirect me towards other possible contacts with expertise on the issue. In the case of an interview, a recording device would be used unless the respondent did not feel comfortable having his / her comments on tape and especially since some respondents chose to have their identity kept confidential.

The email request and questionnaire were drafted in English, French and German. Some of those respondents might have been contacted in one language but responded using another. Here is a sample email sent to a member of the Defense Committee of the House of Commons (The British Parliament)

More specifically, the questionnaire/information requests emails have been sent to the following three groups:

$\rightarrow$ France, Germany, Britain officials/advisors responsible for foreign and defense policy for the 2003-2005 period (or afterwards of they had some perspective about the events). That included, Premier Blair's government, the Chirac Presidency, Chancellor Schröder's and Merkel's administrations. 
$\rightarrow$ France, Germany, Britain members of Parliament, sitting on Foreign Affairs, Defense and European Affairs Committees.

$\rightarrow$ Questionnaires or Interviews with European Commission officials (Directorate General Relex)

$\rightarrow$ Questionnaire or Interviews with European Council Officials (including CFSP)

$\rightarrow$ Questionnaires or Interviews with COREPER and Permanent Representations Officials (the members of the representations constitute COREPER)

$\rightarrow$ Questionnaires or interviews with Members of the European Parliament sitting on Foreign Affairs and Defense Committees.

Here is a summary of the response rate. In the appendix, the list of people contacted is mentioned for each country.

Table 2.6.2: Positive respondents from the Three Member States and the EU

\begin{tabular}{|l|l|}
\hline Case & Number of Respondents (interview or \\
& correspondence) \\
\hline France & 7 \\
\hline Britain & 7 \\
\hline Germany & 13 \\
\hline EU & 16 \\
\hline
\end{tabular}

2.6.3 Press and journal articles, media interviews and speeches

A useful tool to trace the different steps of the debate is the press. The issue has been followed in all the countries of the study, as well as in the US and China. I used predominantly the archives of The Financial Times, a British newspaper that has an excellent coverage of European Union issues and international issues in general. The keywords used in various 
combinations for the search were 'embargo', 'arms ban', 'China', 'France', 'Britain', 'Germany', 'U.S.' and the 'EU’. I included other daily publications. As for speeches, I looked up the websites of the executive branches' offices, legislative branches and European Union institutions. I also used some more scholarly work of folks who studied the EU-China relationship among the Big Three and China and might have used the arms embargo as an example.

\subsection{Tweaking three theories to apply to our study.}

The goal is to evaluate the overall pattern of the three Member States' institutional responses to Europeanization of China policy. In the literature review, I summed up the work by Tanja Börzel on the three types of attitudes (pace-setter, fence-setter, foot-dragger) and the research about EU laws adaptation misfits (Cowles et al., Falkner et al.). All of this research is applied to domestic policies (competition, social policy, transportation...). I would like to apply it to foreign policy and use those theories to test our hypotheses. The Europeanization of a China policy means the development of European policy on China, the enactment of legal procedures such as the embargo, the transfer of competences and the creation of norms and identities at the EU level, in other words as the emergence of European governance. What is the goodness of fit or the mismatch between the EU and the Member States on China policy and do they respond?

First, I identify the relevant Europeanization processes and in this case I expect to see bottom-up, top-down and horizontal Europeanization. The China policy implies a certain set of processes including the arms embargo. These Europeanization processes necessitate some 
adjustments on the domestic level of the member states so that states can be in compliance with EU rules (rules of weapons sales) or necessitate some EU adjustments coming from the member states’ existing policies.

The second step in the framework is to identify the "goodness of fit' between the Europeanization processes and the institutional setting, in other words between what Europeanization of China policy entails and the institutional setting of the member states. The degree of 'fit' constitutes what we identify as 'adaptation pressures'. We are trying to explain whether there was adaptation or convergence; whether the French, the German or the British would adopt the EU policy on China easily or not. The goal of the study is to show how significant adaptation pressures are in the case of Europeanization of China policy at the domestic level and at the EU level. When adaptation pressures are high, European institutions challenge the identity, the constructive principles, core structures and practices of national institutions. And when Member States create those pressures on European institutions (to lift the embargo for example), the identity, principles, core structures and practices of EU institutions are challenged (defense of human rights in the European Parliament for instance). The institutional, material and cultural adaptations can be challenging either for the Member States or the EU institutions.

In cases of high adaptation pressures, the presence or absence of mediating factors is crucial for the degree to which domestic change adjusts to top-down Europeanization or EU change adjusting to bottom-up Europeanization should be expected. I use five mediating factors adapted to our case to predict whether reform will take place:

1. Veto points in the domestic structure. The existence of veto points has been identified as a major factor preventing structural adaptation. The more power is dispersed 
across the political system and the more actors have a say in political decision making, the more difficult is to foster the domestic consensus or 'winning coalition' necessary to introduce institutional changes in response to Europeanization pressures. In our case, we might expect that coalition governments might have more difficulties to comply with a EU policy versus a one party government. The public opinion might be another veto point preventing a EU law to change.

2. A country's organizational and policymaking cultures also affects whether domestic actors can use adaptation pressures emanating from Europeanization to induce structural change. A culture based on consensus for example would overcome veto points. A head of State keen on expanding the relationship with China or who has been an influential in EU-China relations will have an impact on the EU China policy. The leaders of the Big Three all belong to that category.

3. The Human Rights issue is another defining issue in the relationship with the EU and the Member States. Some Member States try to depoliticize human rights and dissociate progress in that area with trade. The German and the French leadership seem to belong to that category. However, for some countries, traditionally the Northern European Member States or for some institutions, such as the European Parliament, human rights ought to be considered as the primary policy under consideration when doing business with.

4. The trade issue could be considered as the 'rival' issue of human rights in terms of importance in the EU-China and the three big States-China relationships. Trade has been the original field of action for Member States and the European Community and now the European Union. Trade between the two amounted to some $€ 210$ billion in 2005, with 
European exports to China valued at $€ 52$ billion and imports from China at $€ 158$ billion. ${ }^{197}$ Tapping the huge potential of the Chinese market represents a boon for sluggish European economies.

5. The empowerment of external actors: Cowles et al. argue that Europeanization leads to a redistribution of power among a whole range of actors outside the policy-making process. In our case, the United States has been a determining influence in the debate and so has China. The United States carefully watched the debate of the lift from its beginnings and heavily lobbied Member States against it.

Using this mixed model allows us to explain the response of the Member States to the Europeanization of China policy based on the mediating factors and attitudes which enabled or disabled policy change.

\subsubsection{Expected findings}

Based on my understanding of Europeanization, the analysis of articles, speeches and the questionnaire, the Börzel classification and the Cowles et al . and Falkner et al. theories, we expect that France, Germany and Britain significantly affect the EU China sanction policy. The issue of the arms embargo has not been resolved, but the three members have been key players in putting and keeping the arms embargo on the top of the agenda one way or another. I expect to find that France and Germany did upload their preferences and influenced other member States to follow their policy choices. Britain was also influential in the debate but more as swing state: originally in favor, but ended up switching positions. The findings should also show that domestic factors (opposition parties, media, public opinion)

\footnotetext{
${ }^{197}$ Griffin Christopher and Raffaello Pantucci. ‘A treacherous triangle? China and the transatlantic alliance’. SAIS Review Vol XXVII no 1 (Winter-Spring 2007), p.163
} 
and external factors (importance of the transatlantic relationship, influence of the US in Asia and China's attitude towards Taiwan) had a key impact on the outcome of the initiative and empowered the will of the Big Member States.

The underlying premise of the debates on whether to lift the arms ban on China was strategic, relating more to the implications for regional and in particular cross-Strait security and stability. The US for instance worried as far as China's intentions and capabilities to make use of prospective arms imports following a lift. However, such concerns were likely to be mitigated as continued and targeted U.S. pressure, compliance with the Wassenaar Arrangement and the EU Code of Conduct, and supplier states' own judgments in deciding the types of armament and defense technologies for transfers would prevent sales of direct lethal military significance. China's own capabilities to absorb imported equipment and technologies and integrate them into its own existing order of battle would also suggest that the transformation effect will take years, if not decades, to materialize. ${ }^{198}$

\footnotetext{
${ }^{198}$ Saalman Lora, Yuan Jing-Dong. “The European Union and the Arms Ban on China”. Center for Non Proliferation Studies (CNS), Monterey Institute of International Studies, July 2004,
} 


\section{Chapter 3}

\section{The influence of France}

\subsection{Introduction}

Although France does not have the same historical ties with China as does Britain or the strong commercial ties as Germany does, France maintains a special political relationship with China. As previously mentioned, France was the first country to establish full diplomatic relations with the communist regime of China. President Jacques Chirac (19952007) always nourished a particular interest in China and during his political career developed personal and warm relationships with the Chinese leadership ${ }^{199}$. France has always been a pioneer or a pace-setter when it comes to EU China policy-making. In 1989, France was one of the main architects of severe sanctions against China following the Tiananmen Square massacre, and almost ten years later launched a bilateral 'strategic partnership' with China ahead of the EU and other big member states. In the issue of the embargo, once again, France seemed to spearhead the plans. First, I will review the track record of France in EU Asia policy. Then I will focus on the embargo and explain the reasoning of the French diplomacy based on the interviews. Then, in order to assess the French responses to Europeanization of China policy, I will use the classification by Börzel ${ }^{200}$ to establish that France was a pace-setter by convincing the EU to put the issue on the agenda and then by trying to convince its partners, and then apply the three-step approach and domestic

\footnotetext{
${ }^{199}$ Barysh Katinka "Embracing the dragon: the EU’s partnership with China” Charles Grant and Mark Leonard, editors, Centre for European Reform, p.19

200 Börzel Tanja, “Pace-setting, foot-dragging and fence-setting: member states’ responses to Europeanization” JCMS 2002 Volume 40. Number 2. pp. 193-214
} 
structural change from Caporaso, Risse and Cowles ${ }^{201}$ and show that there was no mismatch between the EU policy on China and France policy on China, but a mismatch between France and other member states.

\subsection{France's relations with China}

Historically, France and China have always been close sharing similar views of the world. France was the first Western country to exchange ambassadors with the PRC in 1964. De Gaulle and Mao Zedong both wanted to free their nations from the constraints of the bipolar world. Mao at the time talked about "intermediary zones", comprised of developed countries that can side with developing ones in order to isolate the two superpowers ${ }^{202}$. In the 1970s and 1980s, Sino French relations developed steadily as China was starting separating itself from the Soviet Union. France then developed military relations with China (as the United Kingdom and the United States also did) and started selling small quantities of weapons and military equipment. After the cold shoulder following the Tiananmen Square incident, France was the first major country to resume normal relations in $1991^{203}$. Despite the development of military relations with Taiwan, France closely cooperated with China on several international issues, including the settlement of the Cambodia question in 1991. The end of the Cold War, the return to power of a neo-Gaullist majority in 1993, the acceleration of economic reforms in China in 1992 and a French government pledge not to authorize French companies to sell weapons to Taiwan anymore (after a severe decline in these

\footnotetext{
201 Cowles Maria Green and James Caporaso, and Thomas Risse. “Transforming Europe: Europeanization and Domestic Change” Ithaca, NY: Cornell University Press, 2001

${ }^{202}$ Cabestan Jean-Pierre. "Relations between France and China: towards a Paris-Beijing Axis?". China: An International Journal 4.2 (2006) 327-340, 328

${ }^{203}$ Cabestan "Relations between France and China”, 328
} 
relations) led to an unprecedented rapprochement starting in $1994^{204}$. In 1997, as President Chirac was visiting China, both countries established a "comprehensive partnership". This was the second country to establish such a relationship after Russia (which in 1996 concluded a 'strategic partnership' with China), and the first Western state to do so. Again one of the main points of agreement was a certain conception that following the collapse of the Soviet Union, the world was unbalanced because it was overwhelmingly dominated by a sole power. ${ }^{205}$ Since then, Paris and Beijing have shared similar stances on a large number of issues such as Iraq, disarmament, non-proliferation, North Korea, promotion of multilateralism, and most importantly, the sensitive Taiwan issue. Visiting China in April 2005, Premier Raffarin declared that the "anti-secession law" that the Chinese Parliament had adopted a month earlier was compatible with France’s 'one China' policy and the 'one country, two systems' formula was the most appropriate one for solving the Taiwan issue.

This close relationship has been institutionalized through regular bilateral meetings, an alliance on many issues on the Security Council, and rich cultural exchanges. In 1997, France became the first democratic nation to push to abandon attempts to condemn China in the UN Human Rights Commission in Geneva, opting instead for a "constructive dialogue with the Chinese authorities on this delicate issue.” However, today, Paris and China have been having a few difficulties on more recent issues such as Tibet, Iran, Sudan or more generally Africa. Those difficulties have somewhat bridged the gap between Chirac's neoGaullist policy and the EU's common foreign and security policies. France, as a founding member of the EU, has considerable influence on EU foreign and China policies, but it also

\footnotetext{
${ }^{204}$ Ibid. p.329

${ }^{205}$ Ibid. p.330
} 
must take into account the member states’ majority opinion on these matters, including on China.

More generally, when it came to international relations in a post Cold War environment, France and China believed that a multipolar and culturally plural world had already taken shape. In addition, being both independent nuclear powers, 'notably with second strike capability against any bigger nuclear power (Russia or the US)', Paris and Beijing believed that they have a regional role to play that may, on occasions, conflict with American interests. ${ }^{206}$

\subsection{Track record of Europeanization of French China policy}

Under Gaullist (conservative) leadership since 1993, the French used the EU quietly and gradually to increase their presence in Asian political affairs through a process of discrete diplomacy aimed at institution building. French policy makers such as former minister for Foreign Affairs Hubert Védrine, recognized that 'in this immense zone... where we are not the principal partner, interlocutor or protagonist, we do our work with perseverance to make links, create habits of consultation which did not exist before... and slowly but surely, I expect that it will bear fruit. ${ }^{, 207}$

The creation of the Asia Europe Meeting (ASEM) was a classic example of bottom-up Europeanization where France used the EU as a platform to advance its interests and cooperation between the EU and Asia. Following a tense period of relations between France and China from 1989 to 1994, France started to develop a dense network of contacts between French and Chinese leaders. This network not only included diplomatic contacts but also some in the trade, defense and cultural cooperation sectors. The EU followed suit and also established a

\footnotetext{
${ }^{206}$ Ibid p.131

207 Wong Ruben. “The Europeanization of French policy”: France and the EU in East Asia. Palgrave, 2006 p.89
} 
similar system of bilateral meetings. During his 1994 visit to France, President Jiang Zemin proposed 'four principles on Sino-European ties': stable, long-term and friendly cooperation for the $21^{\text {st }}$ century, respect for each other and seeking common ground while putting aside differences, engaging in complementary trade and economic cooperation, and consultation and cooperation in international affairs. ${ }^{208}$ French Premier Balladur seized upon Singapore Prime Minister Goh Chok Tong's proposal of a regular meeting between EU and Asian leaders, based on the APEC model. The French saw an opportunity to re-start their relationship with the Chinese after five years of bilateral difficulties. The creation of the Asia-Europe Meeting (ASEM) institutionalized regular contacts with Chinese leaders in a multilateral European framework without the US and Taiwan. France worked closely with Singapore to convince its European partners to put the initiative on the EU agenda, working through its EU presidency in the first half of 1995 and through its presence in the troika in the second half of 1995. Despite an initial lukewarm response from the British and German governments, France used the offices of former European Commission President FrancoisXavier Ortoli (President of the European Communities in 1973) and the 1995 French EU presidency to push the idea in European circles. ${ }^{209}$ It managed to use EU institutions to build a coalition of support from the other member states and the Commission towards the idea, which led the way to the inaugural ASEM meeting (a summit of EU and East Asian countries in ASEAN plus China, Japan and South Korea) in Bangkok in March 1996. ${ }^{210}$ The ASEM has been a success in facilitating contacts between European and Chinese leaders. The 1998

\footnotetext{
${ }^{208}$ Wong (2005), 84

${ }^{209}$ Wong Ruben. The Europeanization of French policy: France and the EU in East Asia. Palgrave, 2006 p.86

${ }^{210}$ Wong, ibid, p.85
} 
ASEM II allowed Chinese Premier Zhu Ronghi to make his first visit abroad in London and Paris. The first EU-China summit was held in London immediately after ASEM II ${ }^{211}$.

During the same period France also pushed for increased political dialogue with China under the EU framework. In 1996, for instance, France established a high-level strategic dialogue involving defense ministers and senior officials. ${ }^{212}$ The 1997 France-China Declaration on a Global Partnership inspired the 1998 EU Commission’s 'Comprehensive Partnership with China'. Based on the French template, the Commission initiative laid out the principles of a comprehensive partnership, including political consultation, annual summits, dialogue on human rights, support for China's access to WTO, and the promotion of bilateral trade and investment.

In terms of human rights, France followed different models of Europeanization. Three different periods can be distinguished in this rollercoaster on human rights. After the crackdown on the 1989 Tiananmen protests, the socialist French government vigorously pushed for sanctions and led the EU into doing so. With a Gaullist majority voted into office in 1993, France became much softer on human rights and successfully convinced some of its partners (horizontal Europeanization) to boycott the 1997 UNCHR resolution. France’s lead was decisive in reaching a consensus the following year on a common EU position on the resolution, but still had to fall in line with the general EU position (combination top down and horizontal Europeanizations.)

With the 1989 Tiananmen crisis, France played a leading role internationally in supporting the student demonstrations and condemning the Chinese government. Until that point, France had not been too interested in human rights in China except when that involved

\footnotetext{
${ }^{211}$ Wong p.86

${ }^{212}$ Wong p.85
} 
its own citizens. The French Socialist government strongly reacted to the crackdown and infuriated the Chinese government by offering political asylum to the dissident student leaders and gave them a special place in the bicentennial Bastille Day parade. ${ }^{213}$ The French authorities even authorized the dissidents to create an organization, the Federation for Democracy in China. ${ }^{214}$ France initiated the Madrid's European Council sanctions at the EC level and held China accountable in international forums such as the CHR. France had become the leader in the human rights improvement crusade on behalf of the EC.

With a change of majority in 1993, the human rights issue became a secondary one, a culturally relative one. The Balladur government was more interested in catching up on the trade relationship, following the German and Japanese model, (where the bilateral relationship rests above all on trade). ${ }^{215}$ It certainly did not happen overnight and as early as 1991, France had breached EC sanctions on financial aid. With the election of Jacques Chirac, a connoisseur of Asian civilization, this 'semantic-philosophical' approach became established foreign policy. Responding to a question on the French Senate floor, Hervé de Charette, Minister of Foreign Affairs at the time characterized it as 'constructive and dynamic, preferring constructive dialogue to confrontation'.${ }^{216}$ It did not take long for the Chinese government to realize that there was a window of opportunity. At the ASEM Inaugural summit in March 1996, Prime Minister Li Peng urged Chancellor Kohl and President Chirac to drop the annual United Nations Commission on Human Rights resolution

\footnotetext{
213 Wong p.90

214 Ibid p.90

215 Ibid p.90

${ }^{216}$ Wong p.94
} 
criticizing China's human rights record, a resolution the European Community had sponsored six times since $1990 .^{217}$

In 1997, one month before a state visit of President Chirac to China, France broke ranks with the EU practice of sponsoring the human rights resolution on China at the Commission on Human Rights. This reversal was quite stunning, based on the fact that France was the key player in sanctioning the Chinese following Tiananmen. However, the reversal might have been anticipated through different declarations on both sides before the French President's visit. Unsuccessful in convincing its EU partners and the Dutch presidency to drop the resolution criticizing China, France decided to withdraw from the traditional EU support of the resolution and led the 'Airbus Group', including (Germany, Italy and Spain) in defecting from the common position. With the split in EU ranks, the resolution did not pass. Many Western governments criticized French leadership on sabotaging the resolution: according to its partners, France had put short-term economic interests before long-term EU interests, therefore undermining the EU's credibility. During the state visit of President Chirac, the common declaration stated that both parties would 'respect diversity' and take into account the 'particularities of both sides.”218

The following year, EU Member States agreed upon a common position: the EU would 'neither propose nor endorse, either by the organization as a whole or by individual member states, any resolution criticizing China'. The French position had won the day and the 'hardliners' found themselves trapped in a position projected by France. Since 1998, the EU has systematically not cosponsored the resolution. The 1998 position represented an intergovernmental compromise, reconciling various preferences into a common position that

\footnotetext{
${ }^{217}$ Wong, 94

${ }^{218}$ Wong, .95
} 
was not altogether coherent. France brought change to the EU's CHR policy of China, and France had Europeanized its human rights on not confronting China policy by a process of 'exporting its national policy model, ideas and details to the EU' ${ }^{219}$. However, France was also affected by some top down Europeanization (from Brussels) or horizontal (from some other members) and had to coordinate and harmonize its position with the other member states in favor of a resolution. The French stance helped resume dialogue on human rights between China and the EU: the dialogue had been interrupted with the CHR resolution, and, following the French coup and the newly defined EU position, the Chinese deemed acceptable to restart the discussion ${ }^{220}$.

How was the case of the lift of the arms embargo unique compared to other instances of Europeanization of French policy in China? France probably thought it had the necessary influence to see the lift go through based on a successful track record of recent French initiatives in EU-Asia relations.

\subsection{The Reasoning of the French diplomacy to lift the arms embargo}

In the next two sections, I will justify the position of the French diplomacy and establish the French response to the Europeanization of the China policy. I contacted representatives from the executive and legislative branches, based on the timeline but also sometimes though recommendations and...chance.

\footnotetext{
${ }^{219}$ Wong, 96

${ }^{220}$ Wong, 96
} 
The French case to lift the embargo rested on four points: the flaws of the embargo, the tightening of current export rules, the transformation of China and finally the economic potential.

First of all, the current system was not satisfactory. The 1989 recommendation did not constitute an embargo per se since armament licenses exclusively depended on domestic legislation and state authorities. ${ }^{221}$ When the EU arms embargo was announced in 1989, the European Community had no formal foreign and security policy. The decision was taken, along with other temporary steps, such as suspending bilateral ministerial contacts and reducing scientific and cultural cooperation. There was no formal mechanism to govern the embargo enforced by member states until 1998, when the EU introduced a Code of Conduct to regulate its arms sales to the rest of the world. The EU never agreed to make the Code of Conduct legally binding. Instead the rationale was that the increased transparency it established for member states’ arms sales would ensure they abided by its other provisions, such as taking into account human rights, the security of friends and allies, and regional stability. ${ }^{222}$ Despite the initial purpose, the embargo did not stop the exportation of weapons or sensitive technologies to China, since it did not cover dual-use technologies (civilian and military). The embargo, which only covered lethal weapons, was incomplete in any case, and its lift would have minor consequences on the transfer of sensitive technologies. Dual-use technology was already under strict national controls, and the European Union had proposed tightening its code of conduct on sensitive exports if it lifts the embargo against China. ${ }^{223}$ Other countries such as Canada and Australia did not apply or no longer applied such

\footnotetext{
221 Senate Rapport

${ }^{222}$ Dombey Daniel and Peter Spiegel 'Up in arms: why Europe is ready to defy the US and lift its weapons ban on China’ Financial Times, February 10, 2005

${ }^{223}$ Smith Craig. 'In US visit, French envoy seeks support on arms issue.' New York Times, March 29, 2005
} 
restrictive measures and did lift their embargo in 1992. Ultimately, the export license refusal depended on the national export control regime and dual use technology was already under strict state controls. $^{224}$

The second reason motivating a lift was a strengthening of export modalities: the 1998 Code of Conduct was to be tightened, including a revision of the tool box, revision of the military list of the EU, the inclusion of brokering operations, transit and transfer of intangible goods, the mandatory publication of a government report, and specific transparency measures set for countries coming out of the embargo such as notification to the rest of the EU member states of the exports from the last five years, reexamination of the refusal of licenses during the embargo and reporting once every three months of the delivered items). The $1998 \mathrm{EU}$ law was a great guarantee of earnest regulations. The argument was that the EU arms business remained tightly controlled under the code barring the sale of equipment that could be used in regional conflicts or domestic repression, which would still be enforceable on sales to China. ${ }^{225}$

Since the 1996 Wassenaar Arrangement on Export Controls for Conventional Arms and Dual-Use Goods and Technologies, listing which equipment should be controlled through export control lists, practices had been refined and French exports were strictly regulated. Indeed, the Wassenaar list was only a minimal common standard which could be interpreted differently in country lists of controlled exports. French diplomacy thought there was a misunderstanding of their strategic reasoning: despite the lift, high tech products would not be exported, since there might be an issue of counterfeiting the technology: there was a robust

\footnotetext{
${ }^{224}$ French Ministry for Foreign Affairs, Memo

225 Adam Wolfe. "France and Germany move to resume arms sales to China”, Power and Interest News Report http://www.pinr.com/report.php?ac=view_report\&report_id=142\&language_id=1 (February 11, 2004)
} 
internal ruling at both the state and EU level. ${ }^{226}$ "Lifting the embargo doesn't mean at all that we are going to sell more arms to China," declared Michelle Alliot-Marie, French Minister of Defense from 2002 to $2007 .{ }^{227}$ As China continued to direct some 450-plus missiles at Taiwan, there is little chance that any long-range missile technology could be sold to the country. The French and other proponents of the Code argued that this code would provide a safety net to the easing of the embargo -- that would prevent the sale of any technology that could be used to threaten another state. ${ }^{228}$ The embargo was largely symbolic and the same effect could be obtained with strict export controls. ${ }^{229}$

The third argument from France was that China had changed a lot since 1989: there was new leadership and a genuine willingness to integrate with the international community. The French noted Beijing's inclusion in the World Trade Organization and help bring North Korea to the negotiating table. These efforts had thawed relations and reintegrated China in the international order. China was very different from the other embargoed countries such as Sudan, Zimbabwe or Burma. The relationship was from one major power to another ${ }^{230}$. China was also more inclined to perceive this measure as discriminatory, especially since Iran and North Korea were not included. The French government noted some positive developments in the Chinese stance vis-à-vis international standards in nonproliferation. The implementation of Chinese policy in terms of import control of weapons had been strengthened, and France was pleased with Chinese efforts to comply with the existing norms. French diplomacy saw the embargo as anachronistic as relations between Europe and

\footnotetext{
${ }^{226}$ Presidential Advisor, French Presidency, Interview by Vivien Exartier, Elysee Palace, Paris, France, December 18, 2007

${ }^{227}$ Smith Craig. 'In US visit, French envoy seeks support on arms issue.' New York Times, March 29, 2005

228 Ibid.

${ }^{229}$ Smith Craig. 'In US visit, French envoy seeks support on arms issue.' New York Times, March 29, 2005

${ }^{230}$ Presidential Advisor, French Presidency, Interview by Vivien Exartier, Elysee Palace, Paris, France, December 18, 2007
} 
China improved, Beijing was a privileged partner and a responsible one. ${ }^{231}$ Defense Minister Alliot-Marie, among others in the French leadership, argued that it was unfair to maintain an embargo that sent a powerful negative signal. She said that denying weapons sales to China could even accelerate the country's own weapons programs. ${ }^{232}$ The embargo became a stumbling bloc to normalization. French officials were constantly harangued by the Chinese on the issue at almost every bilateral meeting. ${ }^{233}$

The French certainly recognized that there was room for improvement as far as human rights were concerned. France, however, noted some positive progress from the Chinese authorities such as the inscription of human rights in the Chinese constitution and the recent creation of a working group in charge of preparing the ratification of a United Nations pact on political and civil rights. Furthermore, the EU continued a dialogue with China on human rights, which helped to make progress. France did not believe that maintaining the embargo was an effective solution to sustain progress on the human rights issue: it was more a political issue than a trade one. The Chinese did not necessarily need the French to build a tank or a missile, but they were not as advanced as far as helicopter technology, for instance. It was not through the embargo that progress could be obtained in terms of human rights, argued the French. ${ }^{234}$

A non-official reason to lift the embargo was an expansion of the commercial and industrial relationship between the EU and China in a variety of non-defense related sectors that would automatically benefit the French. This was in view of the very significant political

\footnotetext{
${ }^{231}$ Wolfe Adam Wolfe. France and Germany move to resume arms sales to China. Power and Interest News Report, (February 11, 2004).

${ }^{232}$ Craig Smith. "In US visit, French envoy seeks support on arms issue” New York Times, March 29, 2005

${ }^{233}$ Daniel Dombey and Peter Spiegel "Up in arms: why Europe is ready to defy the US and lift its weapons ban on China,” The Financial Times, February 10, 2005

234 Bonnardot Gérard, Army controller / Advisor to the President of the Defense Committee / French National Assembly, Interview by Vivien Exartier, Paris, France, December 132007
} 
weight that such a decision would carry in Chinese eyes, and the lifting of the embargo would actually lead to a string of major Chinese purchases of European products. ${ }^{235}$ According to the European Union, French export licenses for armament to China were valued at \$228 million in 2003, the most of any member country, and up from \$140 million in 2002. ${ }^{236}$ At almost every bilateral meeting, purchase agreements were discussed. When President Chirac argued strongly in favor of the lift of the embargo and an EU recognition of market economy status (MES) to China during his 2004 trip to China, he knew that internal divisions within the EU were too deep to reach a quick decision. Yet, by telling his Chinese counterparts what they wanted to hear, he generated $\$ 4-5$ billion worth of business contracts. During the visit of Prime Minister Raffarin in China in April 2005, forty purchase agreements were signed $^{237}$.

\subsection{The French response to Europeanization of China policy in the case of the arms} embargo

The French EU policy decision making pattern ${ }^{238}$ theoretically includes four aspects: the EU's inner decision-making patterns, France's domestic policy patterns, a process of interest conciliation with other member states, and a process of conciliation between the national and the Community levels. The formulation of French national interest is multilayered and the decision process is more diffuse and under Commission and European Court

\footnotetext{
${ }^{235}$ Enzio Bonsignore and Eugene Kogan. “Fatal attraction: the EU Defence Industry and China”. Military Technology. (June 2005)

${ }^{236}$ Craig Smith. "In US visit, French envoy seeks support on arms issue” New York Times, March 29, 2005

${ }^{237}$ Katinka Barysh Embracing the dragon: the EU's partnership with China Charles Grant and Mark Leonard, editors, (London: Centre for European Reform 2005), 15

${ }^{238}$ Gueldry Michel "France and European Integration: toward a transnational polity”, (Westport: Praeger 2001), 63
} 
of Justice scrutiny, since EU law supersedes domestic law (mostly in pillar I domain). The EU's policy formulation is then often the result of a cumulative process of micronegotiations and micro-decisions by countless actors, public and private over which the central government has little control. However, in the case of foreign policy this does not hold true and in the specific issue of the arms embargo, the top of the leadership formulated and tried to have the policy implemented. The French Parliament does not have much authority when it comes to foreign policy despite a special commission dealing with European Union issues and could only request hearings with government members and EU officials as for China sanction policies.

The goal is to evaluate the overall pattern of French institutional responses to Europeanization, which is defined as the development of European policy on China, the enactment of legal procedures such as the embargo, the transfer of competences and the creation of norms and identities, in other words as the emergence of European governance. What is the goodness of fit or the mismatch between the EU and France on China policy? In previous chapters, we identified the relevant Europeanization processes, formal and informal, norms, rules, regulations, procedures at the European level for member states. The China policy implies a certain set of processes including the arms embargo. They necessitate some adjustments on the domestic level of the member states so that states can be in compliance with EU norms, rules and procedures. Whether these policy adjustments (transposing EU rules into domestic law) lead to domestic structural change is our central research question. We use Börzel's classification of the three types of responses from member states to EU policy on China. I argue there is no mismatch between France and the EU China policy especially in the case of the lift of the arms embargo on China since France has been a pace- 
setter and did upload its preferences at the EU level. We then review the five mediating factors to explain France’s adaptation pattern.

It is ironic to see that France has been a pace-setter on the embargo policy in general: from the set-up of the arms embargo on China to the lift. We explained earlier that France has been a pace-setter on several episodes of the EU China policy and profoundly shaped EU China relations. France has been an instigator of a push to lift the embargo as early as 1997. The issue was first discussed by Robin Cook, the British Secretary for Foreign Affairs, and Hubert Védrine, his French counterpart ${ }^{239}$. The issue was never brought on the agenda by the army or the defense industry. It always has been at head of state level: a defense matter could be discussed within the Defense Council level (composed of the President, the Prime Minister, the Defense Minister, Foreign Affairs Minister, and the Minister for the Economy) or between the SGDN (Secrétariat Général de la Défense Nationale_General Secretariat of National Defense) and the President. ${ }^{240}$ The issue came back to the fore on 30 June 2003, when the French Defense Minister Michele Alliot-Marie visited Beijing and publicly declared a willingness to urge the EU to relax arms restrictions on China. At the time, her comments passed largely unnoticed, as the move was widely perceived as a general attempt to increase French-Chinese trade in all areas, only possibly including arms sales. ${ }^{241} \mathrm{~A}$ few months later, both leaders of France and Germany declared their intention to lift the embargo. France and other proponents of the lift used different ways to promote their agenda: public

\footnotetext{
${ }^{239}$ Hubert Védrine, Former French Minister for Foreign Affairs, Interview by Vivien Exartier, Washington D.C., , November 14, 2007.

${ }^{240}$ Griffin Christopher and Raffaello Pantucci. A treacherous triangle? China and the transatlantic alliance. SAIS Review Vol XXVII no 1 (Winter-Spring 2007)

${ }^{241}$ Kreutz Joakim. "Reviewing the arms embargo on China: the clash between value and rationale in the European Security Strategy”. Perspectives: The Central European Review of International Affairs 22, (Summer 2004): 43-58, 45
} 
speeches, press conferences, interviews in newspapers, requests to discuss it in Brussels meetings, and, of course, private meetings.

While visiting Beijing in December 2003, German Chancellor Gerhard Schroeder told Premier Wen Jiabao that "the time had come" to lift the embargo. On December 12 and 13 at an EU summit, French President Jacques Chirac led European leaders in referring the issue to their respective foreign ministers, urging them "to re-examine the question of the embargo on the sale of arms to China. The foreign ministers would reexamine it in January 2004. ${ }^{242}$ On December 17, the European Parliament rejected such a proposal in a landslide. China's continued human rights abuses were a valid reason not to lift the ban for the European Parliament. The European Parliament has only a consultative role in foreign policy matters, but the strong reaction against the proposal which gathered the support of all of the Parliament's party groups, would probably influence the foreign ministers. ${ }^{243}$

At the first EU General Affairs and External Relations Council meeting of the year in Brussels on January 26, 2004, France suggested that the embargo should be lifted at the next EU Council meeting in March. Foreign Affairs minister Villepin declared: 'Our feeling is that the embargo is out of date as relations between Europe and China improve'. However, Villepin recognized that a lift was not possible yet without further discussion, especially in the area of human rights. ${ }^{244}$ As expected, EU foreign ministers failed to reach an agreement after discussing the issue. They asked two working groups under the European Council, the Committee of Permanent Representatives and the Political and Security Committee, to examine the matter further. The day after the ministerial meeting, President Chirac, at a joint

\footnotetext{
${ }^{242}$ Ching Frank “Changing dynamics in EU-China arms relations”. The Jamestown Foundation, China Brief, Volume 4, Issue 5 (March 8, 2004)

${ }^{243}$ European Report. "EU/China: MEPs reject French pleas over arms ban.” December 20, 2003

${ }^{244}$ European Report. “EU/China: ministers mull lifting arms ban”. January 28, 2004
} 
conference with visiting Chinese President Hu Jintao to kick off the celebrations of the year of China, publicly called for the lifting of the arms embargo on China.,245 Chirac qualified it as 'outdated' and that such an embargo did not make any sense today. Chirac said he hoped the ban on Beijing would be scrapped in the coming months. It is interesting to note that there was not necessarily a consensus within French political class at the time. During President Jintao's speech at the French National Assembly, almost half of the delegates boycotted the event and some were involved in demonstrations with human rights activists outside.

At the EU level though, it appeared at the time that the vast majority of members favored lifting the arms embargo, arguing that China does not belong in the same category as Myanmar, Sudan and Zimbabwe - the three other countries against whom there is an EU arms embargo. Even the Netherlands, which had been reluctant to act, indicated in late January that it was willing to go along if the majority of EU members were in favor of ending the embargo ${ }^{246}$ On February 4, Javier Solana, the E.U. foreign policy chief, was quoted in the Geneva newspaper 'Le Temps' as saying, "It seems to me, after discussions we had a few days ago ... [that] the E.U. is ready to do it." ${ }^{247}$ During the spring, on March 20, as an early result of the aspiration for closer military cooperation with China, the first participation of a European state (France) in joint maneuvers with the Chinese navy took place. That was the largest exercise with a foreign navy in the history of the People’s Republic. ${ }^{248}$

By the fall of 2004, France had about half of the members on its side. EU officials estimate that 16 of the 25 member states favored lifting the embargo (led by France, Italy,

${ }^{245}$ Ching, 1
${ }^{246}$ Ching, 2
${ }^{247}$ Wolfe, 2
${ }^{248}$ German Foreign Policy.com. 'Strategic maneuvers'. March 20, 2004 
Spain, and Germany), while Denmark, Sweden, Norway, Ireland, Portugal, Poland and perhaps one or two other new Eastern European members opposed lifting it. France had planned on having the embargo lifted before the accession of ten new members in $\operatorname{March}^{249}$ and that not being the case complicated the campaign. In September, the UK and the Netherlands were studiously neutral on the issue although both were key actors to swinging the balance, given Britain's prestige and the fact that the Dutch held the presidency of the EU. All European states seemed to agree that the embargo was anachronistic, given the overall health of Sino-European relations and the agreement on a 'strategic partnership'. 250 While conducting an October 2004 state visit to Beijing, President Chirac declared that he would personally strive to end the embargo, the continuation of which was "motivated purely and simply by hostility." Now, expectations were high both on the Chinese and much of the European side that the ban would be lifted by December 8, when EU and Chinese leaders would hold an annual summit in The Hague. ${ }^{251}$

A couple of days before the crucial EU-China summit at The Hague, France came to the fore with its arguments. Through the voice of the Foreign Ministry spokeswoman, Cecile Pozzo di Borgio, French diplomacy repeated that the embargo no longer corresponded to the reality of the European-Chinese strategic partnership, that member states of the EU agreed on this and that the discussions were focused on the time table and the modalities for the lifting of the embargo. ${ }^{252}$

\footnotetext{
249 Wolfe, 1

250 Shambaugh David "China and Europe: the Emerging Axis” Current History (2004)

${ }^{251}$ Kohlmeier Gabrielle "EU eyes lifting China arms embargo” Arms Control Today, (September 2004)

252 Cecile Pozzo di Borgio, Spokesperson of the French Ministry for Foreign Affairs. Agence France Presse Statement, December 7, 2004.

Agence France Presse, December 6, 2004
} 
At the expected seventh EU-China summit on December 8, 2004, in the Hague, the E.U. “confirmed its political will to continue to work towards lifting the embargo.”253 During the summit, France and Germany pushed for and achieved in principle an agreement for the EU towards lifting the partial arms embargo. The agreement, however, did not specify the timeframe. The chance to see the issue resolved by the end of the Luxembourg presidency (first semester 2005) were null, and even the following UK presidency (second semester 2005) was exceedingly unlikely to bring about a firm commitment. Some pessimistic voices contemplated the next window of opportunity as early as mid-2006. ${ }^{254}$ Two weeks later, though, the Council of the European Union approved the Joint Statement and called on the E.U. presidency to "finalize the well-advanced work in order to allow for a decision [on the embargo]" and "underlined that the result of any decision should not be an increase of arms exports from E.U. Member States to China, neither in quantitative nor qualitative terms.”255 The Council further stressed that the E.U. should move to adopt a revised Code of Conduct on arms exports and a new instrument on exports to post embargo countries, known to as the “Toolbox.” Sensing a window of opportunity to advance the French agenda, President Chirac had strong words on the issue during his State visit in China right after the summit. On December 10 in Hong-Kong, President Chirac again characterized the embargo as 'totally obsolete' and that, based on Chinese military production, nothing justified it. Chirac saw the question as somewhat symbolic and thought it was absurd to maintain it. 'I think this is

\footnotetext{
${ }^{253}$ Council of the European Union, Joint Statement, $7^{\text {th }}$ EU-China Summit, The Hague, December 8, 2004

${ }^{254}$ Bonsignore and Kogan, 6

${ }^{255}$ Council of the European Union, 'Conclusions Seventh EU-China summit', the Hague December 8, 2004
} 
becoming the majority feeling in Europe and, in the next few months, I think the matter will be settled, at the European Union level. ${ }^{, 256}$

February 2005 marked the visit of both Secretary of State Condoleezza Rice and President George W. Bush to Europe. The visit was supposed to help mend fences after the Iraq crisis and following President Bush's reelection. The US was strongly opposed to the lift of the embargo. The visits were a good opportunity for French officials once again publicly to call for the lift. The French minister of Defense, Michelle Alliot Marie, in an interview with 'The Financial Times', before a trip to the US to try to persuade the US partners, stated that since China's domestic military industry will be capable of producing 'exactly the same arms' that France has within five years, maintaining the embargo is pointless and 'lifting it could be better protection for us than maintaining it. ${ }^{257}$ President Chirac also took into account US concerns by beefing up security guarantees. ${ }^{258}$ The Head of State always worded it in a way that Europe intends to lift the ban, not just France: "Vis-a-vis China, Europe intends to lift the last obstacles to its relations with this great power of the $21^{\text {st }}$ century, in a spirit of responsibility and transparence with its allies, ${ }^{, 259} \mathrm{Mr}$. Chirac called China "a strategic partner" of the European Union and the arms embargo "unjustifiable”. President Chirac pledged that the embargo would be lifted in such a way that both Europe and the United States could be assured that the strategic balance would be preserved. ${ }^{260}$

\footnotetext{
256 Jacques Chirac, Press conference given by Jacques Chirac, President of the Republic, Hong Kong October 12, 2004

${ }^{257}$ Shambaugh David "Don't lift the arms embargo on China”, Brookings Institution, February 23, 2005

${ }^{258}$ Chen Edwin “Atlantic Divide on China”, Los Angeles Times, February 23, 2005

${ }^{259}$ Rennie David “Crisis over plan to end China arms embargo", The Telegraph, February 23, 2005

${ }^{260}$ France, Presidency of the Republic. "Dinner with President Bush at the US embassy in Belgium”, Brussels February 21, 2005
} 
The EU summit in Brussels on March 22-24, 2005, showed a shift of the coalition. The embargo issue was not on the formal agenda for the two-day EU, but the issue was discussed in private sessions and at news conferences. ${ }^{261}$ France and Germany used the EU summit to reassert their credentials as the leading proponents of lifting the embargo. 'There is no reason to think that there has been a change in this area," said Chirac, the French president. $^{262}$ While Chirac remained committed to resuming weapons sales, EU officials said the leaders of Britain and several other European countries were backing away from making an immediate decision. The EU consensus had fallen apart under increasing pressure from the United States, a new Chinese threat to Taiwan, and intensified criticism at home from the opposition socialist party and the media. French officials believed that the UK had used the controversy over China's anti-secession law as a pretext for meeting US demands. ${ }^{263}$ EU leaders, however, emphasized that they still wanted to lift the bloc's arms embargo on China, while avoiding giving any guarantees on when the controversial move would take place. At the end of the summit, the prospect of a lift of the embargo during the first half of the year, as once planned, seemed out of reach.

Following this failure, the French politicians did not give up. April saw more lobbying from the French to win over reluctant partners. When on the road, Michel Barnier, Minister for Foreign Affairs, always brought up the issue either with his counterparts or during press conferences. In April, Barnier publicly stressed the importance of Europe's burgeoning relationship with China, hoping to see the EU return to the issue in June. "We will continue to work for a lifting of the ban. It is an important element in our relations with

\footnotetext{
261 Frankel Glenn “EU wavers on allowing arms sales to Beijing, Washington Post”, March 23, 2005

${ }^{262}$ Dombey Daniel and Raphael Minder. "Positions unmoved on China embargo”, The Financial Times, March 24, 2005.

${ }^{263}$ Adams Christopher et al. 'Solana to mediate in China arms ban dispute', Financial Times, March 23, 2005
} 
China. ${ }^{264 "}$ A few days later, Barnier met with Danish Foreign Minister Per Stig Moller to discuss several issues, including the lift of the arms embargo. On the eve of a visit to Washington, Barnier made the argument that the EU had a different understanding of the way in which China was evolving on the international stage.” There is a real, fundamental difference of perception that we have about China on both sides of the Atlantic, and it gets back to the classic argument that one cannot treat China like Zimbabwe."265 The US opposition had a déjà vu reminiscent of the rift caused by the invasion of Iraq, with Barnier in the front line rebuffing US criticisms of the European Union's plans to lift its arms embargo on China saying that "warnings or threats" were not "useful" at a time when both sides were trying to improve transatlantic relations.

The French had two difficulties to overcome: not only did they have to win the argument within the EU but they also needed to deliver the lift to the Chinese. As mentioned earlier, the issue was brought up at every Franco-Sino bilateral meeting. During those meetings, government officials needed to remind the Chinese of their commitment to this issue and their dedication to succeed. Such commitment also contributed towards furthering the trade relationship. On a visit to China to sign commercial deals, including the purchase of four Airbus super jumbos worth of $\$ 4 \mathrm{Bn}$, Prime Minister Raffarin reaffirmed to Chinese Premier Wen Jiabao his support for the lift. Raffarin characterized the embargo as "anachronistic, wrongfully discriminatory and in complete contradiction of the current state of the strategic partnership between Europe and China”266. France seemed to lose patience

\footnotetext{
${ }^{264}$ USA Today on line. "EU fails to lift ban on arms sales to Chin”., April 14, 2005, http://www.usatoday.com/news/world/2005-04-15-eu-china_x.htm

265 Thornhill John et al. "French minister defends plan to lift China arms embargo", The Financial Times, April 6, 2005

${ }^{266}$ Ramirez Luis. “China arms embargo outdated, French foreign says” Voices of America, Beijing, April 21, 2005.
} 
over the non-resolution of the issue; Premier Raffarin's words showed certain astonishment in the slowness of the process: "France continues to require the lifting of the embargo and does not see what could lead the European Council to change its position on the subject”267

The French suffered a severe blow to their credibility as an EU leader in the fiasco of the French population's rejection of the EU Constitution project through a referendum in May 2005. There was a vacancy of leadership in the weeks following this astonishing defeat when diplomats and the military were waiting for the instructions from the President on the topic. Some personnel was also starting having second thoughts. At the Defense ministry, there was the feeling that persisting in that direction was not such a good idea. The US could set some retaliatory measures against French manufacturers (major and middle sized ones). ${ }^{268}$ The situation with Germany and Britain also evolved: Chancellor Schröder was getting involved with the general elections, Premier Blair, before the European Parliament, on June 23, 2005, did not mention the issue and did not seem willing to deal with it either during upcoming Britain EU presidency (second semester 2005).

December 2005 saw the first visit of Wen Jiabao to France as Prime Minister. It concluded an exceptional series of exchanges between both countries. Two thousand and four was the year of China in France and 2005 was the year of France in China. Both visits of President Chirac in China and President $\mathrm{Hu}$ in France contributed to the launch of the strategic partnership between the two countries. The strategic partnership certainly helped to deepen the political dialogue and further cooperation in several domains. The visit was a new chance to renew the call for a lift of the embargo. Prime Minister Villepin stated that France's position was well known and had not changed. 'We consider the arms embargo an

\footnotetext{
${ }^{267}$ Hill John “China arms ban hinders developing Sino-EU relations”. Jane's Intelligence Review (June 2005)

${ }^{268}$ TTU Lettre Hebdomadaire d’Informations Stratégiques, « Europe-Chine : la panne », June 29, 2005
} 
anachronism and that it doesn't reflect the real state of relations between China and the international community...We will continue to work for it to be lifted. ${ }^{269}$ France was, however, more isolated on the EU stage since Britain disengaged from the debate and that there was new leadership in Germany that was not so sympathetic to French views on the issue. The Minister for Foreign Affairs, Philippe Douste-Blazy, detailed again the French position in a press conference and recognized the difficulties to further a strategic partnership on the one hand and to maintain an arms embargo on the other. The French case rested on the conclusions adopted by the European Council in December 2004. There was not so much optimism on the issue, however, even if France wished to continue working on this question in order to reach a European decision despite the difficulties. The important point that France constantly repeated, as mentioned in the conclusions of the European Council, was that a lift would not lead to an increase in arms exports to China, quantitatively nor qualitatively. This was stressed repeatedly both at the national level, through the French interministerial committee on the exports of sensitive materials, and at the European level in the European Code of Conduct which defined a number of principles and then an addendum added to the Code of Conduct for countries emerging from the embargo. Douste-Blazy summed up the argument by saying that there was above all a political will to lift the embargo which does not reflect the real state of relations between China and the international community, but at the same time a responsible attitude in not increasing increase arms exports by maintaining very strict control over these exports. ‘270

The issue was not brought up again until the ninth China-European Union summit in September 2006, when the Chinese Premier received a pledge that Europe would continue

\footnotetext{
269 Defense News “French renews calls for EU to end China arms embargo”, December 12, 2006

270 French Ministry of Foreign Affairs “Official visit of the Chinese Prime Minister (December 4-7, 2005)”, http://www.diplomatie.gouv.fr/en/article-imprim.php3?id_article=2989
} 
efforts towards lifting the embargo. One month later, French President Chirac declared his opposition to the embargo in a joint communiqué: "The moment has come for the EU to make the most of the expanding partnership between the EU and China, most notably by lifting the arms embargo which is no longer pertinent to the present situation.,271

A couple of months later, at the External Relations Council on December 11, 2006 France linked the lifting of the arms embargo with an update of the European code of conduct, recalling that it had been decided to update the European Code of Conduct in order to put an end to the sanctions against China. Catherine Colonna, the Minister for European Affairs insisted that the Code could not be adopted until the embargo had been lifted. At this meeting, a large majority of member states were still opposed to lifting the embargo. ${ }^{272}$

Two thousand and seven saw a vacancy in the champions of the lift and gave a coup de grâce to the initiative. Following Chancellor Schröder's departure from office, President Chirac ended his term in May and did not seek reelection. His potential replacements on the French side publicly declared their opposition to the $\operatorname{lift}^{273}$. These contrasted to the repeated calls once again by Minister Alliot-Marie on a final trip to Asia. The new team in Germany also publicly opposed the lift through the voice of the new Defense Minister Jung on a visit to Japan. When Nicolas Sarkozy took office, the official position from the French diplomacy was the same as under Chirac except that the issue is no longer a priority ${ }^{274}$.

\footnotetext{
271 Griffin and Pantucci, 162

272 European Report "Most member states opposed to lifting arms embargo", December 12, 2006

273 www.asia-europe-network.org “Lifting of China arms embargo rejected again”, December 3, 2006

274 Interview with French Presidency Advisor
} 


\subsection{Goodness of Fit}

The Cowles, Risse and Caporaso theoretical model aims at explaining adaptation or convergence $^{275}$. The model does look into the presence or absence of mediating factors to predict whether reform is going to take place and how much domestic change adjusting to Europeanization should be expected. Based on Cowles Risse and Caporaso original mediating factors, the questionnaire and the response of France to the EU China policy, I identified the following factors: veto points, the country’s organizational and policymaking culture, the human rights issue, the trade issue and the empowerment of external actors. At this stage, we already established that there was no mismatch between EU policy and French policy on the embargo policy and that French and EU policies converged. However, in the end of the day, the lift did not go through and it is interesting to review those mediating factors to understand the goodness of fit between French and EU aspirations, but the mismatch with other member states.

The existence of 'veto points' in the domestic structure has been identified as a major factor preventing structural adaptation ${ }^{276}$. The more power is dispersed across the political system and the more actors have a say in political decision making, the more difficult is to foster the domestic consensus or 'winning coalition' necessary to introduce institutional changes in response to Europeanization pressures. In the case of the lift of the arms embargo, the French lobbying was led by the Presidency and the government. There is in the French system a traditional division of labor where the Presidency is the main agenda-setter and decision-maker in foreign policy, and the government mostly in charge of domestic politics. The dynamic of the initiative was successful because the agenda was exclusively controlled

\footnotetext{
275 Maria Green Cowles et al. Transforming Europe: Europeanization and Domestic Change (Ithaca, NY: Cornell University Press, 2001), .5

${ }^{276}$ Cowles et al., 8
} 
by the Presidency and not really questioned within the political framework. The initiative did however fail and did not reach the necessary majority to go through at the EU level. The veto points become then the other member states who blocked the initiative in the European Council.

'The country's organizational and policymaking cultures', seen as a third mediating factor, also affects whether domestic actors can use adaptation pressures emanating from Europeanization to induce structural change. A culture based on consensus, for example, would overcome veto points. The French organizational and policymaking cultures favored a pro-Chinese policy but did not serve it well vis-a-vis its partners. Gaullist France has been historically close to the PRC since the beginnings: President de Gaulle was the one who first recognized the PRC in 1964. When the Gaullist party won by a large majority in the parliamentary election in 1993, there was quite a reversal on China policy and a much more favorable attitude vis-a-vis the PRC, considering the tougher stance under Socialist President Mitterrand (including the setup of the embargo following the Tiananmen Square massacre). President Chirac gave his full attention to the relationship with the PRC as soon as he was elected in 1995 and had been cultivating ties with the Chinese leadership in his precedent positions. President Chirac's conception of a multipolar world implied that China be treated as a peer with its own political and democratic values, with no expectation to follow a Western society model. The French political culture and conception of China's role however did not necessarily match its partners'. There is traditionally a wide range of opinions within EU members when it comes to the relationship with China because it is a multiple-faceted one. In terms of the Franco-Chinese relationship, President Chirac had emphasized a partnership with China based on the economic potential but also for geopolitical reasons. 
Both China and France agreed on the concept of multipolarity to constrain US influence through the establishment of alternatives poles of power. Their joint opposition to the 2003 Iraq War strengthened their ties, and President Chirac was often seen as the most proChinese among European leaders. For some other Europeans, China is a huge threat because it does not comply with social and environmental criteria, intellectual property rights, and of course human rights. "The very positive point of view of Chirac did not suffice to convince the other Europeans to reach a consensus" according to French former Minister for Foreign Affairs, Hubert Védrine. Védrine estimated that the idea of a strategic partnership was mostly words and premature, and translated more as aspirations than anything else. A partnership had been signed but that did not prevent China from increasing its military spending. A consulting mechanism to discuss these questions was essential to set up, but China can certainly not be called as a partner yet. ${ }^{277}$

The stance on human rights was a key factor to determine whether a country would follow the EU policy. The issue separated the pros and cons of a closer relationship with the PRC and ultimately of a lift of the embargo. The French could not obtain consensus within their partners, despite numerous attempts to distinguish between the embargo and the human rights issues. To French diplomacy, these were not questions of the same order. When questioned on the topic, the French leadership always asserted its commitment to the defense of human rights. Chirac, during his visit in China, even called it as a "personal point of pride”. The French were probably not as confrontational as other European powers on the issue, and they believed that it helped them in deepening their relationship with China. France was always encouraged by small steps in the right direction rather than look at a grimmer general situation. President Chirac much appreciated the fact that it was at the

\footnotetext{
${ }^{277}$ Védrine Interview
} 
French National Assembly that President Hu Jintao chose to elaborate on his ideas about the development of human rights in China. "It was a very strong gesture by this great old nation of China, whose culture is different from ours and where any developments naturally take time”. Likewise, France was truly pleased to see that China included the recognition of human rights in her Constitution. From this point of view, the cooperation initiated between specialists in French and Chinese law - French legal experts, professors and technical experts working constantly with their Chinese colleagues to draw up legislation, reforms, codes -was by far the most positive way of moving forward. The French leadership always believed that it was through dialogue, certainly not confrontation, that changes which 'seem desirable for tomorrow's world” would occur. ${ }^{278}$ The embargo was a political question related to the state of relations between China and the international community, and then there was the issue of human rights, but that separation was invisible to the most of the EU members. Chirac's approach to human rights in China was pragmatic and accommodated the Chinese government for cultural relativism. ${ }^{279}$

The trade motivation is essential to understand why France would respond positively to further Europeanization of China policy. Despite a strong showing in the armament market at the time_ French export licenses for armament to China were valued at $\$ 228$ million in 2003, the most of any member country, and up from $\$ 140$ million in $2002_{-}{ }^{280}$ the French economic presence was still lagging behind Britain and Germany. Three sets of factors

278 Chirac Jacques. Press conference given by Jacques Chirac, President of the Republic, Hong Kong, December 10, 2004. http://www.ambafrance-uk.org/Press-conference-given-byM,4385.html

${ }^{279}$ Wong Ruben. The Europeanization of French policy: France and the EU in East Asia. (Basingstoke: Palgrave McMillan, 2006), p.93

${ }^{280}$ Smith Craig. "In US visit, French envoy seeks support on arms issue” New York Times, March 29, 2005 
explained this lackluster performance. First, traditionally, attempts to increase economic presence were driven by large scale 'grands contrats' signed by the French and Chinese governments. The French had failed to coax small and medium sized enterprises. Unlike their British and German counterparts, French businesses were unconvinced of making China a priority in their strategy ${ }^{281}$. France's Foreign Ministry qualified the trade relationship as 'modest and imbalanced'. French companies only supplied $1.4 \%$ of Chinese imports, and the share had shrunk in recent years. The trade deficit with China had been France's largest deficit. Second, French economic initiatives in China tended to shadow policies spearheaded by Germany and to a lesser extent Britain and the European Commission. French governments made a strong political push to catch up with the Germans and tried copying the German model of strong political and economic relations with China. That might explain this unexpected common Franco-German front on the issue of the embargo. Unlike in Germany, however, the social effects of French companies relocations, and human rights questions championed by the French intelligentsia, prevented large scale transfer of French production to China. Third, French economic policies were hamstrung by domestic politics and competing industrial interests. This is no doubt true of French economic strategies in the rest of Asia, but they were worsened in the case of China as a result of especially strong pressures on French government exerted by high-tech military industries, which found a lucrative market in Taiwan, and the demands of aerospace, infrastructure and communication industries, which found in China their most important potential market. ${ }^{282}$

Fourth, the 'differential empowerment of external actors and learning' mattered, whereas Cowles, Caporaso and Risse considered the domestic level only. Structural changes

281 Wong, The Europeanization of French policy, 66

${ }^{282}$ Wong, The Europeanization of French policy, 67 
lead to a redistribution of power capacities among the relevant actors with interests in this policy. The possibility of the lift empowered first the USA who strongly opposed the initiative. The general context was certainly not favorable to a lift, ${ }^{283}$ especially based on the nature of the transatlantic relationship at that time due to the Iraq issue. The American misgiving towards the proposed lifting of the embargo had been well known in official circles ever since France and Germany started the process in late 2003, but it blew up to a major crisis between the US and Europe in February 2005, on the eve of the official visits to Europe by Secretary of State Rice and President Bush. The explosion should be blamed squarely to the appalling ineptitude and inefficiency of the respective bureaucracies and diplomacies, which could have seen the approaching storm well in advance and navigate their political authorities well clear of it. ${ }^{284}$ The American reaction was also rather emotional, preferring threats over a rational analysis of the issues. The Chinese diplomacy also lacked finesse and turned out to be counterproductive, giving extra ammunition to the opponents ${ }^{285}$. The potential rift was too reminiscent of the Iraq crisis and created cracks in the coalition.

The U.S. opposition rested on two arguments. On the one hand, Congress feared that American soldiers serving in the region might one day find themselves facing European weaponry in a showdown over Taiwan, while on the other, there was the fear that American technology or weaponry sold to Europe could leak out and end up again facing American forces in the Asia Pacific region. In February 2005, the U.S. House of Representatives adopted a resolution stating that it deplored increased E.U. sales and moves to lift the embargo, and declaring that those moves "place European security policy in direct conflict with U.S. security interests.” The resolution, which passed by a vote of 411-3, further warned

\footnotetext{
283 Interview with a French Presidency Advisor

${ }^{284}$ Bonsignore and Kogan, 162.

285 Barysh, .60
} 
that, if Europe did not change course, the Congress would have to consider "limitations and constraints” on transatlantic defense-industrial ties. Britain looked at their commercial interests and cooperation programs and would rapidly abandon the ship. But even within the French armament industry, some officials were sympathetic to the Bush administration's concern about the transfer of technology to China. Most of the European defense firms that were doing business with the Pentagon would lose more than they would gain from selling to the Chinese.

The Chinese also involuntarily tanked the initiative when the March 2005 session of the National People’s Congress passed the China's new anti-secession law. The law certainly called for peaceful solutions to the Taiwan question. But it also included a 'trigger mechanism' that would lead to the use of military force if Taiwan took steps towards independence. The British Foreign Minister at the time warned that the law created a 'difficult political environment’ while his German counterpart Joschka Fisher talked about a setback in EU-China relations ${ }^{286}$. It fueled the US rhetoric that arming China would have serious consequences for the cross-strait security of the island. The US had been instrumental in building Taiwan's defense and was committed to defending it in case of an attack. Geopolitically, the US was also opposed to see China challenge the distribution of power in a region that the U.S. currently controls with an accompanying fear that the effects of a potential realignment could occur around the world. ${ }^{287}$

There was no mismatch between France and the EU when it came to a policy to lift the arms embargo. The French weapons export system was compliant and well regulated. France had been a pace-setter in China policy for years and the lift of the embargo followed

\footnotetext{
${ }^{286}$ Barysh, 70

${ }^{287}$ Wolfe, 2
} 
that trend. The French leadership was a key actor in setting the agenda for a EU policy, as the successful outcome of the 2004 The Hague summit showed. Germany was also a heavy weight in the debate as well as some other member states (Italy and Spain) but not to the extent of France, and this partly due to the personal commitment of President Chirac. ${ }^{288}$ There was more of a mismatch between the French and other member states' aspirations. The failure of the initiative was not an issue of effectiveness on the account of the French or the EU, but more of timing, sensitivity and some clumsiness on the part of the Chinese diplomacy. The context prevented a prompt resolution due to a fragile transatlantic relationship, an unconvincing human rights record, and the antisecession law on Taiwan. France was certainly effective in the way the government used every possible means to communicate about the benefit of lifting the embargo: press conferences at bilateral meetings, interviews, agenda-setting in EU meetings (at the Council level and COREPER). Indeed, the initial discussions took place in December 2003 and went on for almost three years without a clear resolution even if it got close to reaching a consensus in several instances. A drawn-out process harmed the French and the Germans, who originally wanted the EU to take action before the 2004 March entrance of ten new members ${ }^{289}$. France probably promised the Chinese that the lift would not be an issue and that it would easily convince its partners, but France did not have the expected influence on the outcomes. France's credibility suffered and showed the Chinese that France did not have the leadership and expected influence within the European Union. ${ }^{290}$ The issue festered due to some

\footnotetext{
${ }^{288}$ Tim Boden, Interparliamentary Delegation for non European countries, European Parliament, Interview by Vivien Exartier, European Parliament, Brussels, Belgium, December 17, 2007

${ }^{289}$ Wolfe Adam. France and Germany move to resume arms sales to China. Power and Interest News Report. February 11, 2004 http://www.pinr.com/report.php?ac=view_report\&report_id=142\&language_id=1

290 Interview with French Presidency Advisor
} 
hesitations from undecided members but also suffered several blows. The anti-Taiwan secession law and the swift and vigorous American campaign crippled the initiative in the Spring $2005^{291}$. By March 2005, most of the members were having second thoughts about ending the embargo by June as initially planned and a loyal US ally, the United Kingdom, would not put the issue on the agenda for their presidency in the second half of the year.

${ }^{291}$ Camille Grand, Director Non Proliferation Ministry Foreign Affairs, Former Advisor Ministry of Defense, Interview by Vivien Exartier, French Ministry for Foreign Affairs, Paris, December 18, 2007 


\section{Chapter 4}

\section{The influence of Britain}

\subsection{Introduction}

Among the three European States, Britain probably has the most developed and extensive ties with China. Britain was in disagreement with the US isolation policy of the PRC between 1949 and 1971 and was the first Western country to recognize the PRC in 1950 (although ambassadors were not exchanged until March $1972^{292}$. In the UK's relationship with China, the colonial past in the form of Hong Kong-still looms large. The 'other elephant in the room' is the US: London's close ties with Washington have at times complicated its relationship with China. The issue of the embargo is a perfect illustration: the UK initially supported the Franco-German initiative but started delaying it when US opposition emerged. I argue there is a not necessarily a mismatch between the UK and the EU China policy but more a lack of consistency. The UK would have had the means to comply with the ban but, politically, switched its mind: the UK was a fence-sitter, then a follower and then a foot dragger on the issue by taking the lead on delaying the initiative. Just as for France and Germany, we will review first UK-PRC relations and the track record of the Europeanization of UK China policy, then examine the reasoning of the British diplomacy in the issue of the embargo before we examine the specific response and finally analyze the goodness of fit between EU and China policy.

\footnotetext{
${ }^{292}$ Wong (2005), 8
} 


\subsection{Relations with the PRC and Track record of the Europeanization of UK- China policy}

Hong Kong was historically the most important political issue between London and Beijing. The return of Hong Kong to Chinese sovereignty dominated the bilateral relations between 1979 and 1997. The Joint Declaration on the question of Hong Kong signed by the two governments on 19 December 1984 ushered in a period of sound development in Sino-British relations, as evidenced by important two-way visits and many agreements signed for cooperation in various fields ${ }^{293}$. However, the fallout from the Tiananmen incident and the appointment of a British activist governor, Chris Patten, in Hong Kong in 1992, disrupted smooth relations otherwise. Following the 1997 handover, the relationship improved since the $\mathrm{UK}^{294}$ received guarantees from China that Hong Kong would keep a large degree of autonomy and a high level of democratic freedom under the 'one country, two systems' principle, as a Special Administrative Unit. The UK watched closely developments in Hong Kong despite an increased EU involvement in China-UK relations ${ }^{295}$ : the future of Hong Kong has increasingly become a EU issue rather than solely a member state one. ${ }^{296}$ But the British often criticize China for the state of the democracy in Hong Kong, which resulted in heated exchanges in 2004. To this day, every semester, the British Foreign Office sends update to the British Parliament and every time, the Chinese

\footnotetext{
293 Xinhuanet News Agency “Brief Introduction to Relations between China and the UK”, May 15, 2002, http://news.xinhuanet.com/english/2002-05/15/content_393213.htm

${ }^{294}$ Wong (2005), 10

${ }^{295}$ Wong (2005), 10

${ }^{296}$ Wong (2005), 10
} 
protest it is an interference in their internal affairs ${ }^{297}$. The British worked hard to win assurances from China that basic democratic freedoms and rights would be respected after Hong Kong was transferred to Chinese sovereignty in July 1997.

While the UK government is still more likely to speak out about democratic shortcomings in Hong Kong than one other EU governments, it does not make too much of an issue about human rights in China. The foreign office website states that 'the human rights situation in China continues to be a matter of serious concern” and it expresses particular concern about the treatment of Falun Gong members (a small handful of whom set up a permanent vigil outside the Chinese embassy in London.) But when Premier Blair visited with his Chinese counterpart Wen Jiabao in May 2004, human rights were not included in the agenda. In its political dialogue with China, the UK has been trying to engage Beijing specifically on African development, climate change, and non-proliferation. ${ }^{298}$

It seemed that ensuring a good relationship with the Chinese partner was a priority in the Blair years, 1997 through 2007. Under Blair's leadership, there was a significant effort to deepen the relationship between these countries through regular consultation and exchange at the leadership level. A comprehensive agreement was signed between prime ministers Zhu and Blair in 1998 to intensify their political and military dialogues and to work together towards a more peaceful and secure world. In October 2003, Chinese Vice-Foreign Minister Dai Bingguo met with William Geoffrey Eheman, director general of the British Foreign and Commonwealth Office and pledged efforts to develop a "comprehensive strategic partnership" to benefit

\footnotetext{
297 Barysh Katinka, 16

298 Barysh, 18
} 
both countries. The goal of such a partnership was to establish a consultation mechanism on strategic security conducive to exchanges and cooperation in security and arms control and, ultimately, to promote bilateral relations. ${ }^{299}$

A year later, at a 2004 December UK -China summit in London, both Chinese Premier Wen Jiabao and British Prime Minister Tony Blair reaffirmed their ties and their common interests in working together on bilateral, multilateral, and global issues and also pledged to develop a "comprehensive strategic partnership". At the time, both countries saw the relationship as a top international priority. Progress had been made since the original discussions in 2003 with the establishment of task forces, aimed at stepping up the development of bilateral relations, which had produced new proposals in trade and investment, finance, energy, education, science and technology, environment and sustainable development during a Blair visit to China in July 2004. In order to consolidate the bilateral relationship and to reinforce and extend political co-operation in fields such as strategic security and nonproliferation, both leaderships agreed to step up the exchange of annual visits. For instance, the UK was pleased with the leadership role taken on by China in the SixParty Talks on Korea. At the same summit, both governments also agreed to stick to the "One Country, Two Systems" principle and the Basic Law concerning Hong Kong and Taiwan. The UK's position on Taiwan had been consistent since the ChinaUK Communiqué of 1972, in which the UK acknowledged that Taiwan was a

\footnotetext{
${ }^{299}$ People’s Daily Online “China, Britain hold strategic security consultations” October 21, 2003.
} 
province of the People's Republic of China and recognized the Government of the People's Republic of China as the sole legal government of China," 300

As for France and Germany, trade had also been an important issue that influenced the British approach. In terms of trade with China, the UK ranked behind Germany, some way behind the Netherlands, and about the same as France. In 2004, the UK imported four times more from China than it exported there (£10.6 vs. 2.4 billion). The UK remained however one of the most important foreign investors in China ( $\$ 19$ billion) at the end of $2002 .{ }^{301}$ It has been even argued in the literature that the key actors in UK-China relations since 1997 are non-state economic ones. In developing a framework for relations with China since 1997, official UK policy towards China has had two main aims: to develop commercial opportunities for UK companies and to promote 'positive' social and political change in China ${ }^{302}$. In theory, economic engagement should create a dense network of transnational interactions that would generate political change in China as it becomes deeply enmeshed in the global economy. In order to achieve this goal, the UK government has transferred much of the power from traditional diplomatic agencies to governmental economic agencies. More important, individual companies, whilst pursuing their own commercial activities, are effectively carrying out government policy in relation to China. Thus, the key actors in post-diplomatic relations with China are increasingly non-state economic actors ${ }^{303}$.

\footnotetext{
300 The Embassy of the People's Republic of China in New Zealand "China, UK vow to develop strategic partnership: joint statement”, December 5, 2004, http://www.chinaembassy.org.nz/eng/xnyfgk/t98154.htm ${ }^{301}$ Barysh, 19

302 Breslin Shaun. "Beyond Diplomacy? UK Relations With China Since 1997”. The British Journal of Politics and International Relations, Vol. 6 Issue 3 (August 2004), 410

${ }^{303}$ Breslin.411
} 
The aftermath of the case of the embargo is an example of an ambivalent British leadership: was Britain totally innocent in trying to clarify the scope of the embargo or was it purely based on trade appeal? The UK was the first one to give a clarification of its interpretation of the arms embargo. ${ }^{304}$ The manner in which the embargo has been interpreted at the state level had always been less than full scope, because the EU embargo was not legally binding, each member state had been free to interpret its scope differently. In June 1995, under the Major administration, the UK decided to enforce an embargo on the sale to China of "weapons, and equipment which could be used for internal repression”305. The UK then identified the kinds of items for which licenses would be denied, including the following categories: lethal weapons such as machine guns, large calibers weapons, bombs, torpedoes, rockets and missiles; specially designed components of the above, and ammunition; military aircraft and helicopters, vessels of war, armored fighting vehicles and other such platforms: any equipment likely to be used for internal repression.

The 1998 Code of Conduct introduced by Robin Cook, the British foreign Secretary was part of the Labour government's "ethical foreign policy"306. The Code of Conduct prohibited EU partners from selling arms to countries that may use them for internal repression, in places where there have been serious human rights violations, and for provoking or prolonging conflicts. ${ }^{307}$ The UK would not permit the

\footnotetext{
${ }^{304}$ Sipri, 15

${ }^{305}$ UK Ministry of Defense, Policy and Defense Relations, "Response to Questionnaire by Vivien Exartier", August 6, 2008

${ }^{306}$ Dombey Daniel, “EU considers binding rules on arms sales”, The Financial Times, April 18, 2005 Monday

${ }^{307}$ Gupta Sonika, "EU and the Arms Embargo" Issue Brief Vol. 1 Issue. 1, Observer Research Foundation, 27 February 2004,
} 
export of goods "if there was a clear risk that they could be used for..external repression or to introduce new capabilities in the region”. 308

While the UK blocked the transfer of lethal items and major weapon platforms, license applications to export other defense articles and services as well as dual-use goods and technologies intended for military applications were considered on a case-by-case basis against the CoC criteria ${ }^{309}$. Under this policy, the UK export control authorities approved exports of equipment which could serve commercial as well as military purposes. ${ }^{310}$ Britain’s interpretation of the embargo would not extend to avionics and radars. ${ }^{311}$ The UK has reportedly supplied China Rcal / Thales Skymaster airborne early warning radars and Spey jet engines for the Chinese JH-7 fighter bombers, Searchwater, an airborne early warning radar system, which is produced in the UK, while the University of Surrey has cooperated with China in micro-satellite technology that could be used in anti-satellite weapons. ${ }^{312},{ }^{313}$. France, Italy and the UK continued to be the leading arms exporters to China whereas other EU states interpreted the embargo more strictly. In 2002, the UK sold arms to China worth of 79.5 million Euros out of a total for the EU of 209.8 and in 2003, 112.46 million Euros out of a total of 461.2 millions $^{314}$

\footnotetext{
${ }^{308}$ UK Ministry of Defense, Response to Questionnaire

${ }^{309}$ UK Ministry of Defense, Response to Questionnaire

${ }^{310}$ Sipri, 15

311 Saalman, 2

312 Seung Chong “Europeans keen to lift arms ban: trade in defence technology has never been entirely closed”, The Financial Times, February 16, 2005

${ }^{313}$ Kogan Eugene. “The European Union Defense Industry and the Appeal of the Chinese Market”. Report, Studien und Berichte zur Sicherheitspolitik, Schriftenreihe der Landesverteidigungsakademie, January 2005, 28

${ }^{314}$ Caruso Raul. "To lift or not to lift? A few notes on the lifting of the European Arms Embargo on China" Crossroads, Vol.5, No 2, (2005), 10
} 


\subsection{Reasoning of the British Diplomacy}

In the next two sections, I will present the position of the British diplomacy and establish the British response to the Europeanization of the China policy.. As I mentioned in our methodology chapter, I contacted representatives from the executive and legislative branches, based on the timeline but also sometimes though recommendations and obtained eight positive responses. (See APPENDIX).

The reasoning of British diplomacy used French and German arguments but also developed its own. Similar to the French position, the UK believed that China could not be treated the same as Zimbabwe and Burma since China was an important partner. Technically, the embargo did not have the force of law, unlike EU embargoes on Sudan, the Democratic Republic of the Congo, Burma, Zimbabwe and Bosnia ${ }^{315}$. The embargo was obsolete and ineffective because of the noncompliance issue and also based on the fact that the EU Code of Conduct governing arms exports was a better instrument for arms control than the current ban. Like the Germans, the British argued that since the CoC would stop arms transfers anyway, a review of the embargo should take place. But mainly, the British were more interested in modernizing the embargo rather than removing it and did show some sensitivity to possible US reactions to the process ${ }^{316}$ The reinforcement of the Code of Conduct became the key argument of the British diplomacy. EU experts agreed to a series of steps to strengthen the code, as well as special transitional measures to increase transparency about arms sales to countries previously the subject of embargoes. Among the changes were controls on the resale of arms, as well as on software that could be used

\footnotetext{
${ }^{315}$ UK Ministry of Defense, Response to Questionnaire, Foreign and Commonwealth Office, Response to Questionnaire by Vivien Exartier, August 15, 2008 ${ }^{316}$ Kreutz, 12
} 
for weapons. The two outstanding decisions concerned whether to make the code legally binding and the duration of the transitional regime. ${ }^{317}$

In early January 2005, Foreign Secretary Jack Straw told a Commons Select committee on Human Rights that the embargo was likely to be lifted in the following six months, despite his personal concerns on human rights and US objections. Straw thought that it was wrong to put China under the same embargo as countries such as Zimbabwe and Burma. Straw testified before the Joint Committee on Strategic Export Controls" "I have long understood China's argument, that to lump them in with, say, Burma and Zimbabwe is not appropriate and I don't think it is,". At the time, Straw foresaw a likely lift of the ban before the beginning of the British presidency of the EU in July 2005. The point of view of Britain was that a strengthened EU Code of Conduct would prevent an increase in the number of arms being exported to China and that the arms control regime would be as effective as it was at the time. The embargo did not cover the sort of high-tech defense equipment that the Chinese military was seeking to acquire. Export of those technologies was controlled by the EU Code of Conduct (COC) on conventional arms, which is the primary means of controlling arms sales. Since May 2004, the COC has had the status of binding statutory guidance in the United Kingdom under EU law. All United Kingdom export licenses were considered strictly on a case-by-case basis against the COC's criteria and the United Kingdom would not permit the export of goods if there was a clear risk that they could be used for internal repression, external aggression or to introduce new capabilities into the region. The United Kingdom did take very seriously the concerns that the United States government had about the effectiveness of the EU's

${ }^{317}$ Dombey Daniel, “EU considers binding rules on arms sales”, The Financial Times, April 18, 2005 
system of arms control and shared the aspiration for continued stability in the East Asian region. ${ }^{318}$

British diplomacy clearly pushed for an upgrade of the Code of Conduct. British diplomats believed that the arms embargo was clearly ineffective in preventing arms sales to China and that a revamped Code of Conduct would take care of the transparency issue. In the UK, more export licenses were refused under the existing European Union arms code than under the embargo. The new Code of Conduct, which was also non-binding, had almost been agreed the year before and included provisions on arms-brokering and intangible transfers of technology ${ }^{319}$ "The code of conduct is much more effective, it's a more powerful tool of and we intend to strengthen it as a pre-condition of lifting the embargo with China," mentioned Straw. ${ }^{320}$ Mr. Straw believed that many of the objections from the US, a major opponent to the lift, were based on a "lack of information and understanding" of how export control guidelines worked in EU countries. ${ }^{321}$ The only reason why the new Code of Conduct not formally approved was because the UK wanted to wait until a transitional post-embargo export regime for China, which was also almost ready. ${ }^{322}$

\footnotetext{
${ }^{318}$ UK Ministry of Defense, Response to Questionnaire

${ }^{319}$ Dombey Daniel and James Blitz "EU doubles arms sales approvals to China”, The Financial Times, January 19, 2005

${ }^{320}$ Dombey Daniel, "EU finalises plan to lift arms embargo on China”, The Financial Times, February 3, 2005

${ }^{321}$ Fidler Stephen, George Parker and Redreick Studemann, “UK expects Brussels to lift China arms ban”, The Financial Times, January 2, 2005

${ }^{322}$ Dombey, February 3, 2005
} 


\subsection{British Response to the Europeanization of China policy: the case of the arms embargo}

Britain never opposed the principle as long as the Code of Conduct was reinforced, that the situation on human rights was improving, and that the timing was right. The US knew they could pressure the UK to oppose the lift. In the beginning of 2004, the UK was slightly reluctant to nail its colors to the mast and just wanted to ensure to 'get the policy and the timing right'. There was agreement that the embargo needed to be reviewed but that was as far as British diplomacy would go for the present. ${ }^{323}$ The possible British interest to lift the embargo raised some concerns in the Bush administration as early as April 2004. The administration expected Britain to block the initiative and was alarmed by the fact that, to the contrary, they supported a review of the lift. The US expressed unease at what it viewed as Britain's equivocation. ${ }^{324}$ In September 2004, Britain was still cautious. At the time, EU officials estimated that 16 out of 25 member states favored lifting the embargo (led by France, Italy, Spain and Germany), while Denmark, Sweden, Norway, Ireland, Portugal, Poland and perhaps the Czech Republic opposed lifting it. The UK and the Netherlands were the most watched countries since their impetus might tip the scale in favor or against the decision. For Britain, it was due to its prestige and influence, for the Dutch, it was due to the fact they were scheduled to hold the rotating

\footnotetext{
${ }^{323}$ www.theparliament.com

${ }^{324}$ Dempsey Judy, "US hits at EU move to lift arms ban on China”, The Financial Times, April 2, 2004
} 
presidency of the EU in the second half of $2004^{325}$ and therefore become agendasetters on behalf of the EU.

During the lead-up to the European Council meeting in June 2004, signals were increasingly coming from the UK that they were in favor of a removal of the embargo but wanted to postpone the decision until after the US Presidential elections later in 2004.The UK insisted on two key arguments before moving forward. The EU Code of Conduct on arms exports needed to be upgraded and improvements to China's record on human rights had to be noticeable. "We are not in any sense against the lifting of the embargo, but it has got to be done in a proper and sensible way... As agreed by the whole of the EU," declared Jack Straw, the British Foreign Secretary at the time. At a private lunchtime discussion with other ministers, he added it was "likely" that most of the arms exports currently prohibited by the embargo would be caught by the Code of Conduct. ${ }^{326}$

The human rights situation was an obstacle to going forward. An influential report by Britain's Foreign Office published in the fall voiced "serious concerns" about China's record on human rights. The report supported the British argument that improvements on China's human rights were necessary, but in the light of those announcements, Mr. Straw sidestepped questions at a press conference on whether he wanted the embargo lifted, saying it was under EU discussion. ${ }^{327}$

But the most vibrant opposition came from the US. Once the Hague European Council summit decided to review the lift, the US started applying greater pressure on

\footnotetext{
${ }^{325}$ Shambaugh (2004), 244

${ }^{326}$ Dombey Daniel, "EU unlikely to lift China arms ban this year”, The Financial Times, October 12, 2004

${ }^{327}$ Adams Christopher. "UK fears on rights in China”, The Financial Times, November 11, 2004
} 
their British ally. The US began threatening to withhold military technology considered crucial to the health of the UK defense industry followed by an expected powerful reaction, particularly in Congress, if the embargo were to be removed. Defense officials said that the most likely reaction would be a withdrawal of Bush administration backing for new measures to improve military technology transfers to European allies and acknowledged that recent efforts made to widen and deepen transatlantic defense industrial trade were going to be circumscribed. The consequences for the British military could have been significant due to its close ties with the American defense sector: BAE Systems and Rolls-Royce happened to be the biggest Pentagon suppliers. In September 2004, Britain had also won congressional backing for special preferred status when applying to gain access to US military technologies, a status that could have been rescinded. Facing those possible sanctions, the UK decided to mount a diplomatic offensive aimed at convincing Washington that lifting the embargo would not lead to a flood of new exports to Beijing. The effort included a three-person UK mission to Washington to explain the British rationale and was part of an effort to take account of a variety of views and ensure important concerns were considered. The standoff had once again put the UK in the awkward role of transatlantic intermediary, a reminder of the Iraqi crisis. British officials argued that US backing for a transparent export control regime would stymie French efforts to make weapons sales more opaque. Discussions with US State Department officials and National Security Council regarding the upgrade of the Code of Conduct certainly helped but the strongest opposition came from the Department of Defense, where top officials believed China would use European technologies to upgrade 
capabilities along the Taiwan straits. ${ }^{328}$ Pentagon opponents said the UK-backed measures were inadequate, and criticized the British for siding with the Europeans on this issue.

However, despite the tensions with the US on the issue, the British government was officially on board in early January 2005. UK Foreign Secretary, Jack Straw told a parliamentary committee that it was "more likely than not" that the lifting of the 15-year-old embargo would happen before the end of the current Luxembourg presidency (June 2005), that "intense discussions" were taking place with US officials to convince them it was the right thing to do, ${ }^{329}$ and that London, Brussels and Washington would have to "manage those differences" in the next few months." 330

Straw acknowledged that the US had a "legitimate and understandable" interest in the effectiveness of European arms control practices and reiterated that a revision of the current EU Code of Conduct would prevent either a qualitative or quantitative increase in the number of arms exported to China. ${ }^{331}$ An upgraded regime would be "stronger than the embargo because it would have force of law and would ensure transparency among EU partners not just on denials but also approvals". ${ }^{332}$ To Straw, the arms embargo was merely a presentational problem and that many of Washington's objections were based on a "lack of information and understanding" of

\footnotetext{
${ }^{328}$ Spiegel Peter "US threat to UK defence groups over China arms: Pentagon decries European plans to lift embargo imposed after Tiananmen Square”, The Financial Times, 24/12/2004

${ }^{329}$ BBC News On Line "EU China arms ban 'to be lifted", January 12, 2005 http://news.bbc.co.uk/go/pr/fr/-/2/hi/uk_news/politics/4167693.stm

${ }^{330}$ Blitz James and Daniel Dombey "Straw admits ending EU arms embargo on China will create tension with US”, The Financial Times, January 19, 2005

${ }^{331}$ Fidler Stephen, Parker George and Frederick Studemann. UK expects Brussels to lift China arms ban, The Financial Times, January 13, 2005

${ }^{332}$ Dombey Daniel and Stephen Fidler, “Top US official rejects Straw's attempt to ease tension over China arms embargo”, The Financial Times, January 20, 2005
} 
how export control guidelines worked in EU countries. ${ }^{333}$ According to Straw, the Americans had not yet understood that the cure could be better than the current state of affairs. $^{334}$

Britain which had shared US reservations about lifting the embargo, had finally gotten on board and was determined that British business should not lose out. ${ }^{335}$ On an official visit to China in January 2005, Straw was expected to push commercial interests and to assure the Chinese of British support to ending the arms embargo on China, in addition to discuss Hong Kong and China's part in the talks on North Korea»336 . A month later, Gordon Brown, UK Chancellor of the Exchequer ,also publicly supported the lift. ${ }^{337}$

However, opposition to the British stance was not only felt in the US but also on the domestic stage. There was debate on the floor of the House of Commons questioning the ethical basis for removing the ban in the face of China's poor human rights record and its missile deployment targeting Taiwan. A Commons' Foreign Affairs committee in March 2005 said the Chinese should first give "strong undertakings" to address human rights concerns before any change of policy was implemented: "The raising of the EU arms embargo on China would send the wrong signal at this time, in the absence of strong undertakings from the Chinese government to address human rights issues." A group which drew together MPs from four Commons select committees concerned with arms sales also raised concerns

\footnotetext{
333 Dombey, January 20, 20051

${ }^{334}$ Dombey Daniel, February 10, 2005

${ }^{335}$ Watt Nicholas “EU could lift arms embargo on Chin”. The Guardian. 01/12/2005.

${ }^{336}$ BBC News On Line, "Straw attacked on China arms deal”, http://news.bbc.co.uk/2/hi/uk_news/politics/4188017.stm, January 19, 2005

${ }^{337}$ Newman Cathy, "Brown backs EU on arms sales to China”, The Financial Times, February 22, 2005
} 
about lifting that embargo. It said such a move threatened "major EU-US trade repercussions" and that was also a risk "EU member states enhance China's military capacity in a worrying way" and arms exported from Europe could be used for internal repression or re-exported to the world arms market”. ${ }^{338}$ The MPS wanted a guarantee from European Union member states that there would be no increase in arms exports to China if the EU's arms embargo were lifted, The group report warned of "major EU-US trade repercussions" from an arms export drive to China. The committee was also critical of government cuts to the Export Control Organization, which assesses applications to export weapons and technology. ${ }^{339}$ Leaders of human rights organizations charged the British government of being forgetful of the Tiananmen Square events. The British Government's response to this was to assure the opposition that Britain continued to be concerned about the human rights situation in China and would like to see more progress on this issue. $^{340}$

The Opposition Conservative party, through the voice of Shadow Foreign Secretary Michael Ancram also criticized the move, arguing that it could undermine NATO as it severely damaged relations with the US and that the British Government was caving in to French and German pressures. Michael Howard, leader of the Conservative Party, also spoke out against the move to lift the embargo on arms exports to China, accusing Prime Minister Blair to appeal to his EU partners at the expense of Britain's national interests. The Tory leader attacked the Prime Minister for his "obsession" with the EU, said lifting the embargo could jeopardize British jobs in the defense industry, and called for the government to adopt an unambiguous

\footnotetext{
338 BBC News On Line, "Pressure to keep China arms ban” http://news.bbc.co.uk/2/hi/uk_news/politics/4381421.stm, March 25, 2005

${ }^{339}$ Adams Christopher "MPs seek assurances over arms to China”, The Financial Times, March 24, 2005

${ }^{340}$ Gupta, 1
} 
stance on the issue. Howard's animated message was not necessarily the most genuine, it was a way to mend fences with the US since he had criticized the Bush administration on the war on Iraq, but it was still heavily publicized and echoed the concerns for potential repercussions on the British defense sector. ${ }^{341}$

The armament industry also started raising concerns. The U.S. campaign to lift the embargo specifically targeted the suppliers for whom the US was an important customer. U.S. government officials, as well as Congress, had made clear that retaliation against European companies would follow if the ban were to be lifted, changing the contracting and procurement environment in America. ${ }^{342}$ British companies were not too keen on upsetting U.S. lawmakers since they had been more successful in the U.S. defense market than their European counterparts. BAE Systems CEO Mike Turner stressed at the time that his company would not do anything to jeopardize its lucrative U.S. business. ${ }^{343}$ It is interesting to note however that some companies favored lifting the embargo on the grounds that it would not alter the military balance. In a letter to British defense officials, the Society of British Aerospace Companies, the trade association, argued that the UK was not making any change to policy with regard to technology transfer to China and was using effective domestic controls to restrict the export of sensitive technologies. Some of those companies saw US opposition to the embargo as intended solely to prevent China

\footnotetext{
${ }^{341}$ Newman Cathy "Howard attacks moves to lift China arms ban” The Financial Times, March 31, 2005

${ }^{342}$ Defense Industry Daily, “China Arms Embargo Controversy Will Have Domestic Ripples”, February 28, 2005

${ }^{343}$ Ibid p.2
} 
becoming as much of a military challenge to US predominance in the region as it was an economic one ${ }^{344}$

During the spring, an intense lobbying campaign took place to woo the US ally. In March 2005, British Ambassador to the U.S. David Manning headed a delegation to Washington, composed of parliamentary defense committee members and representatives of the Confederation of British Industry. US interlocutors were frankly opposed to the policy except for a few legislators including the influential chairman of the Senate Armed Services Committee, John W. Warner (R-Va.), who wanted to avoid another transatlantic rift in the field of defense. ${ }^{345}$ But at the end of the month, the British diplomacy operated a spectacular 360 degrees turn. On the $20^{\text {th }}$ of March, Straw declared on TV that human rights problems and the Taiwan issue become 'more difficult rather than less difficult'. A spokesman for Premier Blair added the same week that the anti-secession law that could authorize the use of force against Taiwan: "Inevitably...soured the atmosphere somewhat”. The leadership still thought that US objections could be met by a strengthened EU Code of Conduct on arms sales to third countries. The British government said it continued to support in principle but had insisted upon updating a code of conduct which would help regulate the kinds of weapons and technology China would receive. It seemed that at that moment, the scale was tipping and there were more countries in the anti-lift group right now than in the pro-lift group. ${ }^{346}$

\footnotetext{
${ }^{344}$ Huband Mark "Arms embargo on China divides defence industry: The next government will come under US pressure to keep the weapons ban during the UK's EU presidency" The Financial Times, April 7, 2005

${ }_{345}$ Anselmo Joseph and Douglas Barrie and Robert Wall. "China showdown” Aviation Week (March 6, 2005), 1

${ }^{346}$ Frankel Glen "EU wavers on allowing arms sales to Beijing”. Washington Post , March 23, 2005
} 
From that point on, the UK reallocated its resources to convince its European partners, starting with Italy, to postpone the lift, possibly until 2006. Straw was now arguing in front of his colleagues for a postponement in particular to Gianfranco Fini, his Italian counterpart. Sweden as well as Belgium was also lobbying to delay the embargo's lifting. ${ }^{347}$ All of British diplomacy was changing its tune, claiming now that the UK had never been "enthusiastic" about lifting the ban, according to Bill Rammell, a junior foreign office minister during a visit in Washington. "We have certainly not been leading the pack on this," he said. Despite the change of heart of the British, the EU did not budge but recognized that the issue was now more difficult and more complex, both in substance and as regards the timeline." ${ }^{348}$ Christina Gallach, spokesperson for High Representative Solana also declared that the EU position had not changed but added that the anti-secession law made the process of decision-making more complex. In terms of human rights, the EU had hoped for a gesture by Beijing in this area, such as ratifying the UN's International Covenant on Civil and Political Rights.

France, which had lobbied hardest for the lifting of the embargo, was still campaigning for a decision by June, but was beginning to realize that a postponement might be necessary. France suspected that the UK was using the anti-secession law controversy over China as a 'pretext' for meeting the US demands. ${ }^{349}$ But other EU members with close defense ties to the US were leaning towards a delay beyond the previously agreed timetable of the first half of this year. The Netherlands, the Czech

\footnotetext{
${ }^{347}$ Dinmore James and James Harding. "Level of US opposition surprises”, The Financial Times, March 22, 2005

${ }^{348}$ Dinmore and Harding

${ }^{349}$ Adams et al. "Solana to mediate in China ban dispute". The Financial Times. March 23, 2005.
} 
Republic, Scandinavian countries, and Luxembourg are among the countries that were having second thoughts about lifting the embargo. There was little enthusiasm for lifting the embargo because of hostile public opinion in these countries, and they would not be opposed to a lengthy delay. A senior Swedish official said China's passing of the anti-secession law aimed at Taiwan had changed EU sentiment." ${ }^{350}$ Western diplomats did, however, play down suggestions that a decision on lifting the ban would be delayed until 2006. There was no evidence that the UK government would seek to shelve discussion on the issue during the presidency of the EU in the second half of the year. The UK was now a bridge between the French approach and the US demands. On the EU side, Britain wanted member states to notify Brussels three months after an export license had been granted. This system would last for 10 years. France wanted a five-year period. The United States was asking for an "early warning system" to be written into the Code of Conduct. This would mean that countries intending to sell weapons to China would be required to consult with the United States. European diplomats agreed that it was difficult to see how a sovereign state should ask permission from the United States to sell weapons.

Britain also proposed the establishment of a regular strategic dialogue with the United States over China and the region, which the French supported. The United States kept applying pressure on Britain in the belief that Blair would use his veto to stop the embargo from being lifted if the issue was put to the vote among the 25

${ }^{350}$ Dinmore James and James Harding. “Level of US opposition surprises”, The Financial Times, March 22, 2005 
member states. Britain, however, claimed that it would not veto any EU decision to lift the embargo, despite pressure by Congress. ${ }^{351}$

The initiative seemed to bear fruit since member states failed to agree at a European Council on April 7, 2005, in Luxembourg on lifting the embargo. Britain, the Netherlands, Denmark and Sweden wanted to retain the arms embargo because of China's shaky human rights record. ${ }^{352} \mathrm{Mr}$. Solana insisted that the EU still planned to lift the ban. ${ }^{353}$ In a series of councils and summits, no mention of the embargo was made, whether it was in June in a EU Council meeting or at the EU China summit in September.

In November, during his three-country European tour, President Jintao brought up the issue again but was told by Premier Blair that the timing was not right, and he was expected to be told by German Chancellor elect Merkel that she would reverse her predecessor's position. Interestingly enough, there were no economic repercussions for Britain and a series of agreements worth 1.1 billion Euros was signed. ${ }^{354}$ The fact that the embargo had moved off the agenda was at the time was a diplomatic victory for the Americans. ${ }^{355}$ Britain agreed not to raise the issue during its current presidency of the EU and the upcoming Austrian presidency agreed to steer well clear of the issue, emphasizing the lack of progress on human rights. ${ }^{356}$

\footnotetext{
${ }^{351}$ Dempsey Judy and Katrin Benhold. "Britain lands in middle of U.S.-EU China spat” International Herald Tribune March 23, 2005

${ }^{352}$ USA Today. "EU fails to lift ban"

353 ibid

${ }^{354}$ European Report. “Arms ban drops off agenda for Hu’s European tour.” November 11, 2005.

355 Ibid.

${ }^{356}$ Financial Times reporters “China arms embargo moves off EU agenda, The Financial Times, November 9, 2005
} 


\subsection{Goodness of fit}

The goal is to evaluate the overall pattern of British institutional responses to the Europeanization of China policy, the enactment of legal procedures such as the embargo, the transfer of competences and the creation of norms and identities, in other words as the emergence of European governance and see which stance the UK adopted using the Börzel, Falkner et al. and Cowles et al. theories. What is the goodness of fit or the mismatch between the EU and the UK on China sanction policy and how did the UK respond to it? Based on Cowles et al original mediating factors, the questionnaire and the response of UK officials to the EU China policy, I identified the following factors: veto points, the country's organizational and policymaking culture, human rights, the trade issue and the empowerment of external actors. I argue there is a not necessarily a mismatch between the UK and the EU China policy but it was not consistent in the case of the lift of the arms embargo. The UK could have applied the lift since its weapons sales are extremely regulated. Applying Börzel's theory, I determine that the UK was a fence-sitter, then a follower and then a foot-dragger on the issue by taking the lead on delaying the initiative. We shall review the five mediating factors to explain UK's adaptation pattern.

The existence of 'veto points' in the domestic structure has been identified as a major factor preventing structural adaptation ${ }^{357}$. The main veto point on the issue of the embargo actually came from the defense industry. Since the early 2000s, several British companies had acquired U.S defense companies. BAE Systems, for example was at the time the sixth-largest defense contractor in the United States. A number of U.S companies had holdings in British defense industry, including Raytheon,

${ }^{357}$ Ibid, p.8 
Lockheed Martin and General Dynamics. BAE Systems Chief Executive Mike Turner was the 'spokesman' against the lift. BAE business in the US is was valued at more than $£ 4$ Billion. In March 2005, the acquisition of United Defense Technologies of the US was announced but there were concerns that the issue of the embargo might lead the US government to block the takeover .To reassure US officials and lawmakers, Mr. Turner has made clear BAE would not be expanding in China even if the ban were lifted. And the opposition from British companies also had an impact on other European multinational armament corporations who had big stakes in the UK and were seeking to expand in the US such EADS, the Franco-German group, Thales of France and Finmeccanica of Italy.

‘The country’s organizational and policymaking cultures' also affects whether domestic actors can use adaptation pressures emanating from Europeanization to induce structural change. The decision-making regarding the embargo was affected by reorganization under the Blair administration and by more structural features of British foreign policy. Regarding EU matters, the New Labor's foreign policy was made through the Prime Minister's office, the FCO and its relevant ministers, the UK Permanent Representation (UKREP) in Brussels, the European Secretariat within the Cabinet Office (Defence and Overseas Policy DOP and the Subcommittee on European Issues). ${ }^{358}$ In 2001, Premier Blair took major steps to enhance the role of Downing Street over both EU policy and foreign policy towards the rest of the world. He moved two of the Cabinet Office Secretariats (dealing with overseas and security and with the EU) under the control of his two foreign policy advisors, Sir Stephen Wall ex head of UKREP and Sir David Manning, ex head of the UK delegation.

${ }^{358}$ Williams Paul. “Who’s making UK foreign policy?” International Affairs 80, 5 (2004): 909-919, 915 
Moving those secretariats under Downing Street authority ratcheted up the role played by the prime minister in foreign affairs and his 'presidential style'. At the same time, it reflected changing patterns in EU policy with the growing number and importance of EU summits, the growing political link among European political parties, and the need to address European issues at a central level. The FCO has been then been sidelined on a number of issues such as the Iraq war, the EU Constitution, relations with Washington, and the general overall strategy and justifications behind British foreign policy. ${ }^{359}$

UK foreign policy had been shaped in large part by a number of aims that had the potential to be both contradictory and complementary. On one hand, Britain has been supporting the USA and guaranteed the "special transatlantic relationship”. On the other, Britain had actively encouraged and engaged in the construction of a European foreign policy provided that it remained based on the consensual coordination of the foreign policies of the EU member states. ${ }^{360}$ Although British positions on numerous foreign policy issues show evidence of adaptation to a European norm, Britain on a number of occasions refused to be bound by European positions while nevertheless doing its utmost to maintain European solidarity over issue areas, such as the Middle East, where it calculates that British influence can be enhanced by collective European action. As a result there can be no clear or consistent sequence to the process by which Europeanization has occurred ${ }^{361}$. Allen and Oliver believe that the nature of CFSP and ESDP makes it possible for national

\footnotetext{
359 Allen David and Tim Oliver. "The Foreign and Commonwealth Office” in The Europeanization of British Politics, ed. Ian Bache and Andrew Jordan, (Basingstoke: Palgrave McMillian 2006), 59

${ }^{360}$ Allen and Olivier, 197

${ }^{361}$ Allen and Olivier, 197
} 
foreign policies to show signs of both accommodating and resisting Europeanization at the same time. There are examples of what has been Europeanized in UK foreign policy-making: the increasing numbers of staff dealing with CFSP, the increased sharing of information through the Correspondent European (COREU) network, the regular meetings of Political Directors and their ambassadorial deputies in Brussels and the development of the Permanent Political and Security Committee (PSC) ${ }^{362}$. However, respondents to the questionnaire and the sequence, of events showed that the Big Three still were able to control the extent, sequence and pace of the uploading dimension of Europeanization ${ }^{363}$, not only in the case of the embargo but in general. The Anglo-French St Malo declaration was an example of this, representing an uploading of British and French foreign policy interests. One of the goals was to further engage Germany on foreign and defense issues by using the framework to effectively 'crossload' foreign policy concerns. ${ }^{364}$

The trade motivation was the key factor to predict that, even if in the first place, the UK was interested in lifting the embargo, it would ultimately abide by the US position. It stems from a contradiction inherent to every member state. The arms trade is both the' fast and slow track' of Europeanization argues Dover ${ }^{365}$. Whilst the European Commission and arms manufacturers are at the forefront of an increasingly Europeanized arms trade, central governments are concerned with protecting economic interests that are now anything but state-centered because of the internationalization of defense industries through mergers, acquisitions and projects.

\footnotetext{
${ }^{362}$ Allen and Oliver, 198

${ }^{363}$ Ginsberg Roy. The European Union in International Politics: Baptism by Fire, (Lanham MD: Rowman and Littlefield 2001), 37

${ }^{364}$ Allen and Oliver, 198

${ }^{365}$ Dover Robert Europeanization of British Defence Policy, (Burlington, VT: Ashgate 2007), 71
} 
The legal arms trade in Britain was viewed by government officials as being a core function of the state and an indispensable part of the British economy. Moreover, the legal arms trade has foreign policy implications. The British government's view was that they could expand their influence across the world. Sales to Saudi Arabia since the eighties were justified on the grounds of being able to influence a strategically important government in the Middle East. ${ }^{366}$

The UK uploaded its preferences to the supranational level through the establishment of the European Defence Agency, which provides the EU with an ability to influence the development of technology and, by inference, the procurement and sale of these materials. It was no coincidence that the first Chief Executive of the EDA was British (and a former MOD and FCO official). Arms manufacturers had a large role in the working groups that designed the EDA: high ranking European Commission officials sat with representatives of BAE Systems and EADS as well as the President of the European Defense Industries Group to advice on how the new institution should operate, providing great access to manufacturers. However, with this new diplomatic tool came the tension inherent in individual arms programs. How to promote weapons manufacturers on one hand and make sure that human rights are respected on the other? The Code of Conduct, aimed at making the trade more transparent and less open to claims of corruption, was certainly a great safeguard against questionable deals ${ }^{367}$. But, the primary concern was not whether China was a questionable partner, but what other partners might think. That explained how BAE Systems and other British companies with large interests in the US declared that they

\footnotetext{
${ }^{366}$ Dover, 117

${ }^{367}$ Dover, 118
} 
would not sell military equipment to China regardless of the EU position because they wanted to keep the US happy. This demonstrated the influence of British arms manufacturers on state policy-making and the effect on the European stage, with the ban on exports to China remaining. ${ }^{368}$

Fourth, the 'differential empowerment of external actors and learning' mattered, while Cowles et al. and Falknet et al. considered the domestic level only. The possibility of the lift empowered the USA, who strongly opposed the initiative. The close relationship between the US and the UK certainly gave a great deal of influence to the US. Premier Tony Blair had this view that he and Britain had a unique role to serve as a bridge between Europe and the United States. An ambitious form of internationalism was developing in Blair's outlook, whereby he wished to reconnect Britain to its European destiny, to help modernize the EU so it would be fit for an era of globalization (a Blair mantra), and above all to stay close to the United States, as the ultimate guarantor of British security ${ }^{369}$. Blair in March 2001 declared: "I have been as pro-America as Prime Minister as it is possible to have. There is no single issue I can think of in which we have not stood foursquare with America”370. At the time, it was said that Robin Cook was replaced as the head of FCO by Jack Straw for being too European and not enough pro-American. Mr. Blair was already insouciant about opening up a distance between himself and his French or German colleagues over foreign policy questions. In part, this was because of the enormous self-confidence that the Prime Minister had in his ability to make a personal

\footnotetext{
${ }^{368}$ Dover, 119

${ }^{369}$ Hill Christopher. "Putting the world to rights: Tony Blair’s foreign policy mission” in The Blair Effect 20015, ed. by Anthony Seldon and Dennis Kavanagh, (Cambridge: University Press 2005), 388

${ }^{370}$ Hill (2005), 389
} 
difference on some of the great international issues. Almost by definition, this implied that he would be in competition with his peers, President Chirac of France and Chancellor Schroeder of Germany. Bush and Putin in Blair's mind represented real power in the unsafe world outside the 'postmodern' European Union, and Blair sought to accommodate and to charm them ${ }^{371}$.

Just like many prime ministers in the post-war era, Tony Blair became increasingly preoccupied with trying to be a mediator between the United States and Europe, committed to a multilateral international order and determined to play a major positive role in the European and international affairs whilst trying to preserve the illusion of Britain as a major power, even if both the European and American dimensions of British foreign policy continued to lack domestic support ${ }^{372}$.

Behind the ideological rhetoric, the UK was fearful of US repercussions especially for its armament industry, and a possible lift gave the US a golden stick to punish the British partner. The UK government was stung once by Congress's refusal to waive certain requirements of its International Traffic in Arms Regulations for the export licensing of certain unclassified military exports from the United States to Britain. Lifting the waiver would have helped with interoperability - since shared systems by different armies would make it easier for them to fight together ${ }^{373}$. The Americans feared that a China armed with weapon technologies from Europe facing American forces in the South China Sea would change the post Cold War geopolitical

\footnotetext{
${ }^{371}$ Hill (2005), 389

${ }^{372}$ Allen and Olivier, 197

${ }^{373}$ Allen and Oliver, 199
} 
order. ${ }^{374}$ Members of the US Congress had warned they would respond to a lifting of the embargo by passing legislation restricting US technology transfers to European defense companies.

Condoleezza Rice, the U.S. Secretary of State, ratcheted up the US rhetorical opposition on several occasions, including one trip in China, where she stressed that lifting the European Arms embargo could "change the equilibrium" in Asia. ${ }^{375}$ Ultimately, the British government had no choice to be a go between the EU and the US, and therefore postpone the debate, certainly not wanting to upset the US ${ }^{376}$.

\subsection{Conclusion}

The attitude of the United Kingdom in the case of the China arms embargo reflected the deep attachment to one of the most important premises of British foreign policy: a commitment to serve as a bridge the US and Europe, and ultimately ensure the satisfaction of the US partner. The transatlantic bond overcame aspirations for political and economic power in China. Britain could have been a pace-setter on the issue, given its powerful arms industry looking for markets, the attachment to Hong Kong, and the ambition to be a major defense player in the EU. Instead, Britain sat on the fence and witnessed France and Germany taking the lead on the issue. Britain then jumped on the bandwagon till the US, using a carrot and stick policy, threatened the UK to retaliate by cancelling some defense contracts. Britain then switched outfits

\footnotetext{
${ }^{374}$ Dombey Daniel and Peter Spiegel. "Up in arms: why Europe is ready to defy the US and lift its weapons ban on China”. The Financial Times, February 10, 2005

${ }^{375}$ Dinmore Guy and James Harding, "UK seeks support for move to delay lifting of EU's arms ban on China”, The Financial Times, March 22, 2005

${ }^{376}$ Keetch Paul, Liberal Party Member of Parliament, Interview by Vivien Exartier, House of Commons, London, UK, December 10, 2007
} 
again to, this time, use its influence to reverse the process and convince other members through horizontal Europeanization that the lift was not a reasonable policy. The foot-dragging attitude was at its paroxysm when the UK decided not to put the embargo issue on the agenda of the second half of 2005.

The successful pressure applied by the United States on the United Kingdom checked the hypothesis according to which a EU sanction policy could not be modified unless the US approves it. What makes the UK case interesting is the fact that the UK used its influence to block the initiative rather than promote it. The UK used horizontal Europeanization by convincing other members to delay the initiative and as EU President used top-down Europeanization by not putting the issue on the agenda.

The empowerment of external actors such as the United States prevented the UK to adopt the lift and the impact of the US overpowered the influence of other mediating factors that could have led to the adoption of the lift. Trade could have predicted the outcome either way: on one hand, the UK sold dual-use equipment goods to China and would have certainly benefited from the opening of the market; on the other hand, the UK defense market was heavily dependent on the US one. As for human rights, the issue was not dramatic enough n=in British public opinion to impact the outcome, one way or another.

In terms of safeguards for weapons exports, there was no misfit between the UK and the EU, and the UK could have easily adopted the ban, based on the regulation of its defense export market. By reversing itself, the UK diplomacy 
appeared to have misled the Chinese into complacency and left them wavered in the wind. $^{377}$

${ }^{377}$ Godement Francois. “Europe’s second thoughts on China Embargo”. Yale Global (March 25), 2005,.2 


\section{CHAPTER 5}

\section{The influence of Germany}

\subsection{Introduction}

While commercial ties have flourished, political ties between China and Germany have remained underdeveloped. Most Chinese still see Germany as an economic partner. Germany has traditionally tied its foreign policies close to those of its fellow EU members. Germany became a model for many member states in the 1990s with its pragmatic economic approach, outlined in the German Asia Concept in 1993. The model rested on three principles: silent diplomacy (i.e. avoiding open human rights accusations), change through trade "Wandel durch Handel”, (i.e. encouraging political liberalization in China through economic development), and last, the application of a strict “One China” policy ${ }^{378}$. Chancellor Schröder (19982002) fully followed this model and visited China more often than any other non-EU country during his tenure. Germany's China policy is a rather odd combination of trade promotion, foreign aid - increasingly shaped as trade promotion, too - and a certain support for social modernization. Schröder's strong involvement in the German-Franco initiative to lift the EU weapons embargo came under fire from the political opposition, the media, the Federal Parliament (Bundestag) and human rights activists. The arms embargo issue also caused divisions within the ruling coalition, with the Green party vehemently opposed to it, other EU member states and the

\footnotetext{
${ }^{378}$ Stumbaum May-Brit. The European Union and China. Decision-making in EU and Security Policy towards the People's Republic of China, DGAP-Schriften zur Internationalen Politik, (Baden-Baden: Nomos, 2009), 85
} 
United States ${ }^{379}$. First, I will review the track record of the relations between Germany and China and Germany's influence on in EU Asia policy. Then I shall focus on the embargo and explain the reasoning of the German diplomacy based on the interviews. Equally important, in order to assess the German responses to Europeanization of China policy, I will use the classification by Börzel ${ }^{380}$ to establish that Germany was a pace-setter by convincing the EU to put the issue on the agenda, by trying to convince its partners, and then apply the Cowles et al. and Falkner et al. theories to show that there was no mismatch between the EU and German sanction policy on China but that there many veto points within Germany’s domestic level that weakened the German bid.

\subsection{Relations with the PRC and Track record of Europeanization of China policy}

Germany's relations with China have been far steadier than those of Britain and France. Germany, based on its defeat in World War II, had no colonies and never had any ties with Taiwan either ${ }^{381}$. On the international stage, Germany did not take diplomatic initiatives and tended to follow cues from its major Western allies, such as the recognition of the PRC in 1972 following the Nixon visit. China had been primarily dealing with East Germany since the mid-fifties, from which it imported industrial equipment (East Germany was the most important communist trading

\footnotetext{
${ }^{379}$ Barysh, 16

380 Börzel Tanja, "Pace-setting, foot-dragging and fence-setting: member states’ responses to Europeanization” Journal of Common Market Studies Volume 40. Number 2, (2002): 193-214

${ }^{381}$ Wong (2005), 11
} 
partner of China. To East Germany, China represented an alternative model to the Soviet Union and the two shared a struggle for international recognition ${ }^{382}$.

Trade with West Germany represented the backbone of the relationship. The Federal Republic opened its first trade office in 1955, despite the "Hallstein doctrine" banning diplomatic recognition to all states that recognized East Germany ${ }^{383}$. Even today, the German Ministry for Foreign Affairs primarily promotes economic relations, which are developing with breathtaking speed into a success story. The PRC has become Germany's most important export market in Asia. Germany is China's greatest European trading partner and, lately, has also become the greatest European investor in the PRC. ${ }^{384}$ Chancellor Kohl was the architect of the German success throughout the 1980s and the 1990s during which he adopted a policy of “silent diplomacy" focusing on trade and ignoring the human rights issues. Under Helmut Kohl, the focus on economics and the neglect of human rights or Beijing's policy vis-à-vis Taiwan caused criticism from opposition leaders. The so called “dialogue behind closed doors” on politically sensitive issues was seen as a way to save the Chinese leadership from open criticism and to satisfy German public. In general, bilateral relations between Germany and the PRC had intensified during the government of Helmut Kohl. Although it supported the EU Council's sanctions policy following the Tiananmen incident, Germany under Kohl resumed trade cooperation six months later and never really stopped high-level contacts, breaking

\footnotetext{
${ }^{382}$ M.J. Esslin. “East Germany: Peking-Pankow Axis?” The China Quarterly, No. 3 (Jul. - Sep., 1960): 85-88 ${ }^{383}$ Wong, 4

${ }^{384}$ German -Foreign- Policy.com. “Background Report: Strategic Partnership and Containment” January 5, 2004, http://www.german-foreign policy.com/en/fulltext/40108?PHPSESSID=i6ug0kg390914k0sjmr5grchv3
} 
away from the economic sanctions before they were officially lifted in September 1990.

Germany was always very cautious on issues dealing with sovereignty and national unity, unlike the British handling of Hong Kong and the French stance over Taiwan. Germany did not maintain diplomatic relations with Taiwan on account of the 'One China Policy’ pursued by Germany, along with all the other EU Member States. Germany is in favor of Beijing and Taipei coming to a peaceful resolution of all the issues of concern ${ }^{385}$. For example, Chancellor Kohl refused to approve the sale of ten submarines and ten frigates to Taiwan in January 1993 and reaffirmed Germany’s ‘one China’ stance ${ }^{386}$. Three principles of German China policy were drawn during the Kohl years: silent diplomacy (hence no human rights confrontation); change through trade (encouraging political liberalization in China via economic development); and a strict “one-China” policy.

Vis-à-vis the EU, Germany seemed to have a slightly different approach compared to France and Britain with the idea of influencing EU policy rather than adopting a unilateral approach. The assumption was that regional and security policy developments in Asia were now having a greater impact on European foreign and security policy. "Where developments in Asia generate a global impact, that is to say directly affect our own interests, we must exercise our influence nationally, within the EU framework ${ }^{387}$. For instance, German officials are deeply committed to the AsiaEurope Meeting (ASEM) process. Germany also stresses the importance of

\footnotetext{
${ }^{385}$ Federal Foreign Office, "East Asia_Japan, South and North Korea, Mongolia, China including Hong-Kong and Macao Taiwan_ at the beginning of the $21^{\text {st }}$ century”, Tasks of German foreign policy, Auswärtiges Amt (German Foreign Ministry Archives), Berlin, (May 2002), 7

${ }^{386}$ Möller, 16

${ }^{387}$ Möller, 2
} 
multilateral frameworks such as the G7 or the United Nations and other international organizations. Germany has been keen on supporting the ASEAN Regional ForumARF) to improve security and confidence building in the region, for example on the basis of experiences in the CSCE/OSCE. One of the main tools advocated by Germany in its China policy is confidence building and détente in a dialogue on security policy rooted in cooperation in the field of military policy, including a discussion of arms control policy issues. More generally, the major foreign policy concern is to integrate China into the International Community. It is essential to convince China that as a rising regional power and member of the Security Council, it bears increasing responsibility for world peace, for stability in the Asia-Pacific region and for global concerns, including a peaceful resolution of all the differences arising on the two sides of the Taiwan Strait ${ }^{388}$.

To Germany, cooperation is inherently linked to the improvement of the human rights situation. Relations with the PRC cooled down in 1996 in the aftermath of an all-party Bundestag resolution on Tibet accusing China of trying to eradicate Tibet's cultural identity ${ }^{389}$. A planned visit to China by Foreign Minister Klaus Kinkel was postponed and the matter was not resolved until late September of that year, when Kinkel and his Chinese counterpart Qian Qichen met in New York ${ }^{390}$. To this end, Germany has engaged bilaterally and within the EU in a dialogue on human rights with the Chinese government at expert level. Human rights issues are an important part of a political dialogue at Foreign Ministerial level, and in talks

\footnotetext{
${ }^{388}$ Möller, 8

389 Peking Teresa Poole "Kinkel goes fence-fixing in China”, The Independent, October 23, 1996

${ }^{390}$ Weske Simon, “ The Role of France and Germany in EU-China Relations”, EU-China Studies Center Programme,(August 2007), 8
} 
between the Commissioner for Human Rights and Chinese Government officials. ${ }^{391}$ Human rights also have been an important issue for the German media, the public opinion and most prominently the Green Party which was a junior partner in the post1998 coalition government. ${ }^{392}$ In September 1998, Foreign Minister Joschka Fisher declared that there would be "no further kowtow towards the 'Beijing dictatorship'”. As a symbolic but strong gesture, Chancellor Schröder invited a prominent Chinese dissident to Germany and upset the Beijing leadership. The appointment of a Human Rights Representative further emphasized the greater role human rights were supposed to play in dealing with the Chinese leadership. In 1999, the Red-Green government initiated a "Dialogue on the Rule of Law" at the bilateral level and within the EU framework. ${ }^{393}$ The Dialogue on the Rule of Law was meant to offer a longterm approach to building a state based on the rule of law and implementing human rights in China ${ }^{394}$. It consisted of specific projects to improve legal and judicial practices in China. The Dialogue combined elements of careful public criticism, open talk behind closed doors, and pragmatic cooperation at the bilateral and the EuropeanChinese level.

The "Dialogue on the Rule of Law" has often been hailed as one of the major innovations of the Red-Green Asia policy, although there had been various similar programs in place under the Kohl administration. Most of the cooperation projects implemented by state actors as well as by private actors had actually already been

\footnotetext{
${ }^{391}$ Weske, .6

392 Weske, 31

${ }^{393}$ Volmer Karl . "German policy on Asia-Everything different after 11 September? -Speech by Minister of State Volmer, Berlin, Tuesday, 25 June 2002.

${ }^{394}$ German Ministry for Foreign Affairs, "Bilateral relations with China”

http://www.diplo.de/diplo/en/Laenderinformationen/01-Laender/China.html
} 
under way before the establishment of the Dialogue. Officially arranged symposia were the only new element introduced as an additional venue for German-Chinese cooperation in the field of law. However, the symposia did not provide an appropriate framework for discussing sensitive issues related to human rights and the rule of law since they were conducted in a formal, decidedly non-controversial atmosphere. In essence, the Dialogue thus only integrated already existing governmental and private legal cooperation initiatives under a common heading and a symbolic umbrella.

The main function of the Dialogue was not a practical, but a politicalsymbolic one. Prior to Dialogue, the German government's handling of human would consist of articulating individual objections, handing over lists of political prisoners and asking for their release. In the course of the 1990s, this approach was increasingly felt to be humiliating to the Chinese side, politically ineffective and potentially damaging to economic exchanges. By initiating the Dialogue, it became possible to delegate discussion of the PRC's human rights record from the official diplomatic sphere to the working level involved with legal cooperation programs. With a view to appealing to public sentiment in Germany, the German government could present the Dialogue as a comprehensive human rights strategy directed towards the Chinese government. The Dialogue thus became a valuable symbolic tool in the hands of the German coalition government for deflecting human rights sensitivities among its electorate and preventing human rights controversies from disturbing the rapid expansion of economic relations with China. ${ }^{395}$

\footnotetext{
395 Schulte-Kulkman Nicole “The German-Chinese 'Rule of Law Dialogue’:

Substantial Interaction or Political Delusion”, in German-Chinese Relations: Trade promotion or something else, ed. Overhaus Maro, Sebastian Harnish and Hans Marell , German Foreign Policy in Dialogue, NewsletterIssue 16, Vol. 6, Trier, Germany, June 23, 2005, 36
} 
The prioritization of domains has been the key of the German China policy and certainly inspired other Member States as well as the European Union in general. European states did not develop a unified position towards the PRC despite early moves by the UK, France, and the Netherlands to set up diplomatic relations in the 1950s and 1960s. Attempts by other countries such as Germany and Ireland to create individual China policies were quickly abandoned. In 1993, Germany took a leadership role by inserting a new programmatic dimension to EU China policies by developing the first 'Asia- Concept'. Germany was a pace-setter and uploaded its policy preferences at the EU level in a positive way. It served as a blueprint for the first Asia policy program of the European Union which improved the coordination of national policies towards PRC. In general, 'bilateral' relations between the EU states and Asia were conducted within the framework of state-related programs or cooperation agreements of the so-called 'third generation'. ${ }^{396}$

The first German Asia Strategy was clearly dominated by the 1990s discourse on a potential Asian hegemony due to the rise of Japan, the Asian Tigers and China. However, the Kohl and the Schröder governments took some criticism from the public opinion and opposition parties for neglecting human rights and systematically depoliticizing economic relations with China ${ }^{397}$. Germany grasped the importance of Asian new markets when EC trade with East Asia overtook EC-US trade for the first time in 1992, and therefore took the lead in formulating its 'Asian policy'. The central ideas of Germany's Asian policy were to strengthen economic relations with the largest growth region in the world, restore high level visits to Beijing and stop

\footnotetext{
${ }^{396}$ Gottwald Joern-Carsten “Europe and China: Convergence, Politicization and Assertiveness”, East Asia (2010) 27:79-97, 82

${ }^{397}$ Gottwald, 82
} 
applying pressure on human rights. In December 1993, Chancellor Kohl returned from a visit to China with a pile of contracts and letters of intent. ${ }^{398}$ A few months later, Bonn was the first Western capital to host a visit by Chinese Premier Li Peng, in spite of Li's close association and responsibility for the Tiananmen crackdown. Germany continued to assume a leadership position, along with France, in influencing EU Asia policy and pushed for stronger involvement in the region.

The success of the German model prompted other member states in particular Britain and France (each had issues with Beijing, over Hong Kong and Taiwan) to rethink their post-Tiananmen policies and to also depoliticize a more aggressive economic relationship. In the mid-1990s, Germany alone accounted for nearly $40 \%$ of total EU trade with China, over twice as much as Britain's. Besides the depoliticization, the role of the private sector has been the key factor in German economic success. In other member states, the government was the initiator of business dealings. In Germany, the private sector was the initiator and the government served as a facilitator. ${ }^{399}$ Following the German model, French and British government delegations to China systematically started inviting business leaders. Michael Heseltine, the British Secretary for Trade and Industry visited China in 1994 accompanied by 130 businessmen ${ }^{400}$. The German model also influenced French willingness to deal pragmatically with China. Following an era where the French socialist government distanced itself from the Chinese regime based on human rights records, France-China relations were normalized and a joint France-

\footnotetext{
${ }^{398}$ Wong (2005), 4

${ }^{399}$ Wong (2005), 4

${ }^{400}$ Wong (2005), 5
} 
China communiqué was issued in January 1994 during Prime Minister Balladur's visit.

Germany and France were then the first member states to begin to normalize relations with China after the Tiananmen Square crackdown. They went so far as to violate EU restrictions on aid and loans to China several months before these sanctions were collectively ended. ${ }^{401}$ This pragmatic stance also impacted the way the embargo on weapons was observed, and Germany, like other Member States breached it several times.

The largest share of its 2003 license approvals for China were specialized military training equipment or simulators (€528 thousand), electronic military equipment ( $€ 433.1$ thousand), and software items ( $€ 134.4$ million) ${ }^{402}$. For example, MTU, a DaimlerChrysler subsidiary, built diesel engines, which were not subject to licensing requirements and therefore were sold to the Chinese and used in their SongA submarines. Chinese Naval war ships were also equipped with MTU engines. Other companies such as Deutz built engines used in Chinese tanks. But as mentioned in the chapters about France and Britain, the other big two also sold parts that could be used in military equipment. Britain's Rolls Royce Spey jet engines are used in Chinese JH7 fighter jets and the French Racal long-range airborne radar systems are used by the Chinese Navy Aircraft. ${ }^{403} 404$

\footnotetext{
${ }^{401}$ Glen Carol and Richard C. Murgo "EU-China relations: balancing political challenges with economic opportunities”, Asia Europe Journal (2007) 5:331-344, 338

${ }^{402}$ Kogan, 28

${ }^{403}$ Linsdsey Daryl “A transatlantic Crisis foretold” Spiegel Online, March 18, 2005

${ }^{404}$ Kogan, 28
} 


\subsection{Reasoning of the German diplomacy}

In the next two sections, I will justify the position of the German diplomacy and establish the German response to the Europeanization of the China policy. It seems appropriate to list here the officials who have been contacted to help in this endeavor. As I mentioned in our methodology chapter, I contacted representatives from the executive and legislative branches, based on the timeline and recommendations.

Under Chancellor Schröder's guidance, the priority in Germany’s policy towards the PRC was firmly established: trade promotion first, foreign aid, second and issues of human rights and democratization a distant third. Publishing its three regional concepts for East Asia, South East Asia and South Asia in May 2002, German diplomacy made it official that it had fallen in line with the tradition set by its predecessor. The global economic and political integration of the PRC gained highest priority while political change and social modernization were moved on to various arenas of bilateral and multilateral cooperation. ${ }^{405}$ The position of the German government echoed the French one. The major difference, however, was that the position was articulated at the top and at the top only. In the French case, President Chirac was certainly a big promoter but was followed by his cabinet, whereas in the German case, some of the cabinet members did not necessarily agree with the Chancellor, including the Minister for Foreign Affairs, Joshka Fisher.

Chancellor Schröder stated that China had changed significantly during the last fifteen years and no longer resembled the China of 1989. In the Chancellor's view, political and legal change within China continued to be positively promoted by

\footnotetext{
${ }^{405}$ Gottwald, 92
} 
the "German-Chinese Rule of Law Dialogue" that was initiated in 1999. This Dialogue was presented as a substantial and continuous effort at improving the human rights situation in China and as proof for the German government's political and moral dedication in its China policy. ${ }^{406}$ Germany acknowledged the human rights deficiencies in China, from freedom of opinion to minority rights and death sentences but saw its role more as a supporter of the positive trends rather than a denunciator. German diplomacy based its reasoning on the increasing number of concrete cases and the legislative initiatives under way in terms of civil and political rights and thought that their supportive stance had something to do with such progress. ${ }^{407}$

Increasing sales of weapons was never part of the argument: Germany's national regulations on arms exports were stricter than in most of the EU members including France and the United Kingdom. ${ }^{408}$ Domestic law prevented most direct arms sales to China due to foreign trade law which prohibited the selling of defense goods into areas of crisis or potential crisis. At the EU level, the Code of Conduct would also prevent sales of high-technology weapons sales to states with repressive regimes. ${ }^{409}$ Ultimately, argued German diplomacy, if the embargo would have been lifted, Germany would not have profited very much from it since the sales of goods with potential defense use would have been inconsequential. ${ }^{410}$

There were also a few geopolitical reasons to justify the lift of the embargo. According to German diplomacy, regional and security policy developments in the

\footnotetext{
${ }^{406}$ Schulte-Kulkmann, 31

${ }^{407}$ Benoit Bertrand Benoit and Mark Odell. “Germans hoping for Euros 1bn deals with China”, The Financial Times, December 4, 2004

${ }^{408}$ Umbach Frank "Will the EU Arms embargo towards PR China be lifted? Perspectives and implications" Taiwan Perspective e-paper, Issue no 29, (June 23, 2004),.5

${ }^{409}$ Umbach, 5

${ }^{410}$ Stefan Axel Boese, staffer of Axel Schäfer, Bundestag Member, Committee on European Affairs Member, Phone Interview by Vivien Exartier, May 16, 2008
} 
Asian region also generated a global impact, affected German interests and therefore impacted the European foreign and security policy. The Germans must use their influence as a state within the EU framework, internationally as in the Asia Europe Meeting (ASEM), multilaterally through the UN and the G7 and the G8. ${ }^{411}$

During the long period of East-West bipolarity, Asia as a whole and its large sub-regions did not identify themselves permanently with either of the two politicomilitary blocs. ${ }^{412}$ China, France and Germany agreed on the concept of multipolarity to constrain US influence through the establishment of alternative poles of power, such as China, all opposed to a unipolar world. A European pole would mean greater influence for Germany and France and both countries shared views when it came to defense and foreign policy issues. Moreover, the joint opposition to the 2003 Iraq War strengthened France and Germany ties. ${ }^{413}$ Chancellor Schröder and President Chirac had become close and there was a sense in German diplomacy circles that "if the French were for it, then the Germans were for it too...” 414

Finally, regionally, there had been a push by the German diplomacy to solidify military policy cooperation with China and India through a trilateral defense dialogue. In 1994, consultations had been initiated as a "German-Indian defense dialogue" by the Konrad Adenauer foundation of the Christian Democratic Union (CDU) in cooperation with India's leading defense policy think tank, the Institute for Strategic Studies and Analyses (IDSA) and, since 1997, China. Every year, the

\footnotetext{
${ }^{411}$ Auswärtiges Amt, Federal Foreign Office "Tasks of German foreign policy, East Asia: Japan, South and North Korea, Mongolia, China including Hong Kong and Macao, Taiwan at the beginning of the $21^{\text {st }}$ century”, Berlin, May 2002, 2

${ }^{412}$ Ibid., 2

${ }^{413}$ Bonsignore and Kogan, 8

${ }^{414}$ Interview with Boese
} 
discussion partners coordinated the views of Beijing, Delhi and Berlin concerning strategic developments in Asia and discussed contingencies for cooperation on the continents "defense problems". ${ }^{415}$

But the main reason behind the desired lift of the embargo was trade expansion. France, Germany and Spain had certainly pushed for the lift of the ban based on economic considerations. Increasing trade with China at all levels was an important part of stimulating economic growth ${ }^{416}$. The trade promotion was part of Chancellor Schröder's platform since he had made the economy and employment the center of his governing program. The Chancellor systematically tied the economy to foreign policy and therefore could not turn down the huge opportunities of the Chinese market ${ }^{417}$ The trade relationship between Germany and China was characterized by impressive numbers. Within Europe, Germany was China’s leading trade partner, accounting for around $30 \%$ of total E.U.-China trade ${ }^{418}$. Bilateral trade between China and Germany reached some $€$ 33,5 billion in 2004 (+31\% over 2003), and was projected to double again by 2010, Some 2,000 German companies, including major banks, operated in China. BASF and Bayer, for instance, were the largest chemical firms in China, Volkswagen controlled $30 \%$ of the Chinese car market, and in 2004 it produced more cars in China than in Germany with Chinese sales accounting for 1/3rd of the company's net profits. Germany was also by far the largest EU exporter to China, accounting for $44 \%$ of the total of its exports. Between 1997 and 2005 German exports to China increased by almost 300 percent. According

\footnotetext{
${ }^{415}$ German-Foreign-Policy.com “Strategic Maneuvers German Foreign Policy” March 20, 2004,.2

${ }^{416}$ Saalman Lora, Yuan Jing-Dong. “The European Union and the Arms Ban on China”. Center for Non Proliferation Studies (CNS), Monterey Institute of International Studies, July 2004

${ }^{417}$ Interview with Boese

${ }^{418}$ Griffinand Pantucci, 164
} 
to the German Engineering Association, in 2004 China became Germany's ' secondbiggest export market after the US, taking France’s spot. ${ }^{419}$ German investment in China also increased ten-fold from just $€ 800$ million in 1995 to $€ 7.9$ billion in 2003, making Germany China's seventh largest foreign investor, continues to rise, and Germany is the leader among EU member states in terms of foreign direct investment (FDI) in China. France also witnessed significant Foreign Direct Investment growth; by 2004 these two countries accounted for approximately $40 \%$ of EU foreign direct investment in China. ${ }^{420}$ The quality of this economic relationship has also been strengthened by Germany's willingness to provide soft loans to China as well as export subsidies for companies doing business in the Chinese market. ${ }^{421}$ Finally, Germany has been the most generous donor to China. In the second half of the 90s, Germany alone accounted for more than half of the EU aid to China (at the time 15 member states), mostly in legal reforms, environmental protection and transport infrastructure projects. ${ }^{422}$ The depth of the economic relationship certainly justifies Chancellor Schroeder's enthusiasm for lifting the arms embargo.

The importance of maintaining a capable and robust defense industry across Europe was shared both by President Jacques Chirac and the German Chancellor Gerhard Schröder. Under normal circumstances, Kogan argued that no top-level political leaders would stick their neck out and take a personal commitment to ensure the lifting of the embargo, for the sole purpose of actively fostering arms exports ${ }^{423}$.

\footnotetext{
${ }^{419}$ Atkins Ralph and Hugh Williamson. "German exporters beat a path to the China market: Hopes are riding high on the latest trade trip, headed by chancellor Gerhard Schröder”, Financial Times, December 6, 2004

${ }^{420}$ Glen and Murgo, 342

${ }^{421}$ Glen and Murgo, 341

${ }^{422}$ Wong (2005), 11

${ }^{423}$ Kogan, 11
} 
Rather, what really motivated France and Germany were the consequences that a decision to lift the arms embargo might have. It would have led to an expanded commercial and industrial relationship between the EU and China in a variety of nondefense related sectors.

\subsection{German response to the Europeanization of German policy: the case of the embargo}

In early December 2003 on a visit to China, Chancellor Schröder declared that China was now considered a responsible partner in world affairs that had little in common with the 1989 leadership, implying that the arms embargo could be removed. The Chancellor was confident that he could obtain an EU majority to lift an arms embargo against China.

On the same trip, the Chancellor also announced his support for a Chinese request to buy a nuclear plant from the Siemens AG in spite of the technology's military potential. Touching upon the nerves of a growing number of Green party members this initiative in addition to the attempt by the Chancellot to lift he EU ban on arms sales met considerable public opposition. The idea of exporting nuclear technology was strongly disapproved by the Green Party, member of the governing coalition, with its strong antinuclear tradition, but also by the opposition. The Greens were not too keen on lifting the embargo, based on the poor human rights record of China but they eventually understood that even if the embargo were to be lifted, German export restrictions and the Code on Arms Conduct would still prevent arms 
sales to China. The issue of the lift would need some explaining but seemed winnable. The Chancellor certainly did not expect however, that in a rare case of successful involvement in foreign policy-making, the parliamentary fractions of the Social Democrats (SPD) and the Green Party would threaten to block the government’s export permission of plutonium. ${ }^{424}$

In January 2004, Foreign Affairs Minister Fisher, a Green Party member, argued that more discussions with the Chinese were necessary concerning human rights and the Taiwanese question, but declared that he supported the review as long as the Code of Conduct was updated. Later in the spring, the plutonium deal was postponed indefinitely, following more domestic criticism in Germany. ${ }^{425}$

A few months later, there were still reservations among the members of the junior partner of the coalition. In an interview on television, Minister Fischer recognized that there had been great progress in China, but there were still reasons for having considerable reservations on lifting the embargo based on human rights abuses: excessive use of the death penalty, administrative detention, Tibet and the right to political freedom, but also the conflict with Taiwan. Fisher mentioned that he stood for the one China policy and at the same time believed the Taiwan question should be resolved peacefully. However, Germany was very active in holding discussions with the EU regarding the lifting of the arms embargo and wanted to make sure that a consensus was reached before this move. ${ }^{426}$ The press was not favorable to the lift and characterized the move as opportunistic and as an attempt to

\footnotetext{
424 Gottwald, 10

${ }^{425}$ Kreutz, 12

${ }^{426}$ Joshka Fiher's Interview on current political issues on n-tv, July 28, 2004
} 
"pick up lucrative Chinese contracts for German business in the pinch of a stagnant economy, ${ }^{427}$

In October 2004, the parliamentary majority was still not convinced about the benefits of the lift and rebuked the chancellor by rejecting his efforts to lift the European Union's arms embargo against China. In October 28, the German Parliament, including the vast majority of Chancellor Gerhard Schröder's own Social Democrats and virtually all of Foreign Minister Joschka Fischer's Greens, passed a resolution which called on the German government to make any relaxation of the 15year arms trade ban conditional on these measures. ${ }^{428}$ On November 19, the European Parliament passed a similar resolution 572 votes against 72. And on March 11, leaders of the four German political parties representing Germany in the European Parliament sent an open letter to Schröder urging him to abandon his support for China arms sales. ${ }^{429}$ In the same month, the Bundesrat also adopted a motion urging China to ratify a United Nations' treaty on human and political rights, speed up the implementation of recent civil rights reforms and grant ethnic minorities additional autonomy.

In December 2004, before the Hague summit, Chancellor Schröder went to China for the sixth time with 35 business leaders, on a trip largely dedicated to solicit business. More than 150 companies had applied to go. ${ }^{430} \mathrm{~A} € 1$ bn deal to sell 23 Airbus aircraft was finalized and Siemens, the engineering group, had already secured

427 Glen and Murgo, 337

${ }^{428}$ Benoit Betrand and Daniel Dombey. "Schröder thwarted over China arms ban”, The Financial Times, October 28, 2004

${ }^{429}$ Tkacik John, “E.U. Leadership Finds Little Public Support for Lifting China Arms Ban”, Web Memo, Heritage Foundation, March 17, 2005

${ }^{430}$ Atkins Ralph and Hugh Williamson. "German exporters beat a path to the China market: Hopes are riding high on the latest trade trip, headed by chancellor Schröder”, Financial Times, December 6, 2004 
a $€ 360 \mathrm{~m}$ deal on the sale of 180 locomotives. Once again, on the home front, Chancellor Schröder's mercantile approach to foreign policy was criticized, especially because he put human rights concerns on the backburner. ${ }^{431}$ This was his conviction that his country's economic interests came first, leading him to believe that the Tiananmen Square events were a thing of the past.”432

At the expected seventh EU-China summit on December 8, 2004, in the Hague, the E.U. “confirmed its political will to continue to work towards lifting the embargo.”433 During the summit, France and Germany pushed for and achieved in principle an agreement for the EU towards lifting the partial arms embargo. ${ }^{434}$ Once the Hague Summit decided to review the lift, the US started to voice their opposition but mostly pressured the UK as a traditional transatlantic bridge. During the spring of 2005, both Secretary of State Condoleezza Rice and President George W. Bush visited Europe. The visit was supposed to help mend fences after the Iraq crisis following President Bush's reelection. Not to throw oil on the fire, the U.S. President and the German Chancellor graciously overlooked the China arms issue as well as any rows over Iran's nuclear plans. "We have the same goals," the president said, putting on a good show. In Berlin, advisors to Chancellor Schröder believed the whole commotion in Washington was being exaggerated since President Bush had

\footnotetext{
${ }^{431}$ Benoit Bertrand and Mark Odell. “Germans hoping for Euros 1bn deals with China” The Financial Times, December 4, 2004

${ }^{432}$ Kogan, . 24

${ }^{433}$ Council of the European Union, Joint Statement, $7^{\text {th }}$ EU-China Summit, The Hague, December 8, 2004

${ }^{434}$ Bonsignore and Kogan, .1
} 
not brought up the issue. ${ }^{435}$ On the other hand, the German Chancellor did not want get in another argument with President Bush or with the American Congress. ${ }^{436}$

In the meantime, the European Union consensus had seemed to fall apart and what was supposed to be a formality turned out to be more complicated. While France was still committed to the embargo, the leaders of Britain and several other European countries were backing away from making an immediate decision. The position of Germany was unclear. The embargo was not on the formal agenda of the two-day summit in Brussels; however, it was discussed in private sessions. In Germany, domestic opposition kept rising in the Parliament ranks. In April, EU foreign ministers met in Luxembourg and could not reach a consensus on the issue despite an intense lobbying campaign to convince the US partner. Officials said privately, that the issue might be put off until at least 2006. Britain was scheduled to hold the EU presidency in the second half of 2005 and had just reversed its position, and was now opposing the lift. Despite the stunning British reversal, German leadership was still cohesive. Foreign Minister Fischer at the time declared that ending the ban depended largely "on movement by Beijing, especially on the question of human rights and a peaceful resolution" of its conflict with Taiwan. Before the German Parliament, Fischer testified that the ban hindered Europe's efforts to boost trade with China and that a greater Chinese commitment to human rights would help forge an EU consensus on lifting the embargo. ${ }^{437}$

\footnotetext{
435 Spiegel Online International The China Arms Embargo: “Sketching Out the Next Trans-Atlantic Crisis", March 3, 2005, http://www.spiegel.de/international/0,1518,345333,00.html

${ }^{436}$ Frankel Glenn "EU wavers on allowing arms"

${ }^{437}$ USA Today "EU fails to lift arms ban"
} 
It seemed that the German leadership was involuntarily losing control of the issue. The media, the public opinion and the parties were expressing their strong feelings against the lift. ${ }^{438}$ The Chancellor was not in a comfortable position since the Chinese were keeping the pressure on. In an interview, the Chinese ambassador to Germany, Mr. Ma, called the embargo "embarrassing' and "discriminating". Ambassador Ma clearly stated that the lift would give an impulse to China EU relations, but until then, the relationship could not be normal. Ambassador Ma had spent much time meeting German politicians from all the political parties in an effort to convince them that keeping the embargo served no practical purpose. ${ }^{439}$

In June, some polls showed the Conservative Party, the CDU, well ahead of the leading government, the Social Democrats, suggesting a possible change of ruling party in the fall. Wolfgang Schäuble, CDU foreign affairs spokesman, told Bloomberg that if his party took office after the elections expected in September it would not end the ban without US consent. The CDU rejected the approach according to which Europe should be a counterweight to the US. Schauble believed that stronger co-operation between the large centers was the alternative and only then Germany would be more accountable to all of its partners." ${ }^{440}$ The CDU was pressuring on having a vote at the Bundestag, but Schröder had declared that he would disregard any vote because certain foreign policy issues could only be decided by the Chancellor. $^{441}$

\footnotetext{
${ }^{438}$ Tkacik John, "E.U. Leadership Finds Little Public Support”

${ }^{439}$ Dombey Daniel, (June 14, 2005_.

${ }^{440}$ Dombey Daniel. "EU drive to lift China arms ban falls apart”. The Financial Times, June 14, 2005.

${ }^{441}$ Dempsey Judy “China lobbies EU over arms embargo”. International Herald Tribune, April 6, 2005
} 
The general election and change of leadership at the Chancellery in November 2005 gave the last blow to the initiative. Both major parties had to form a grand coalition. The coalition pact between the CDU led by Angela Merkel and outgoing . Schroder's Social Democrats agreed to pursue a "long-term strategy of partnership" with China, but stated that the "dialogue on democracy and human rights would be intensified". Ms. Merkel, the upcoming Chancellor, refused to support the lift of the embargo until human rights significantly improved and had criticized Mr. Schröder for placing too much emphasis on the expansion of business ties with China. Ms. Merkel did not even discuss it when Chinese President Hu visited Germany during the transition period. Even on the SPD part, there were increasing concerns about the trade imbalance between China and Germany. The CDU seemed to have won the backing of their partner in the coalition. Wolfgang Clement, outgoing Economics Minister in the Schröder cabinet, told his Chinese counterpart that while bilateral trade had expanded rapidly in recent years - reaching $€ 53 \mathrm{bn}$ (\$ 62bn) in 2004, the balance "was becoming somewhat distorted", with Chinese exports to Germany expanding by 26 percent this year, but trade in the opposition direction shrinking 5 per cent and called on China to open its markets more fully, intensify efforts to end product piracy and stop abuses of intellectual property rights. Hu also held talks with Schröder who told him, much to the anger of Merkel's Conservatives, that he believed the European Union would find a "sensible solution" to its arms embargo on China, that his opinion on the arms embargo had not changed, and that Germany would work with France on this issue." 442

\footnotetext{
${ }^{442}$ Deutsche Welle. „Hu meets Merkel As Germany Reaffirms EU Arms Ban“, November 11, 2005
} 
Furthermore, the rifts between the incumbent and previous governments within the new coalition were highlighted when the CDU drafted a new strategy defining Asia’s rise as a strategic challenge and potential opportunity for Germany and Europe. It emphasized several issues with China such as copyrights, economic espionage and disadvantages in monetary joint ventures, and called for a shift in attention from China to India. This change was not necessarily welcome by the minister of Foreign Affairs, a SPD member, who favored the traditional approach of Mrs. Merkel's predecessors Helmut Kohl and Gerhard Schröder. The Chinese reaction to this new approach was also harsh. Given the uneasiness of the situation, the government publicly emphasized the continuity element in its policies but still left aside the embargo. ${ }^{443}$

\subsection{Goodness of fit between EU and German China sanction policy}

The goal is to evaluate the overall pattern of German institutional responses to the Europeanization of the European China policy. What is the goodness of fit or the mismatch between the EU and the Germany on China sanction policy? Once again, I apply the Börzel, Cowles et al. and Falkner et al. models to explain the German adaptation $^{444}$. At this stage, it is already established that there was no mismatch between EU policy and German policy on the embargo policy and that German and EU policies converged. Germany had no issue reversing the ban and arms export regulations were stricter than the Code of Conduct. Using Börzel's classification and based on the previous sections of the chapter, I can also now establish that Germany

\footnotetext{
${ }^{443}$ Gottwald, 87

444 Cowles et al., 5
} 
was a pace-setter along with France. Chancellor Schröder was influential and not just a follower of President Chirac. Schröder had at a certain time considered to make a proposal to the relevant EU bodies to lift the embargo ${ }^{445}$. Regarding mediating factors, to be able to compare with the other two countries, Britain and France, I used the same factors: veto points, the country's organizational and policymaking culture, the human rights issue, the trade issue and the empowerment of external actors.

The weight of the veto points was crucial in harming the effectiveness of the German leadership and its campaign towards a lift of the ban. The existence of 'veto points' in the domestic structure has been identified as a major factor preventing structural adaptation according to Cowles et $\mathrm{al}^{446}$. The more power is dispersed across the political system and the more actors have a say in political decision making, the more difficult is to foster the domestic consensus or 'winning coalition' necessary to introduce institutional changes in response to Europeanization pressures. There had been a great deal of domestic debate and opposition, given public opinion, Green party and CDU's objections to perceived ongoing human rights abuses in China. ${ }^{447}$ The timing of the issue was also under scrutiny since the lift was not a decisive issue for the economic prosperity of the country but certainly a divisive one based on the different political leanings within the German government. ${ }^{448}$ The question of lifting the EU arms ban has turned into an animated power struggle between the Schröder government and members of the coalition. That made the German case

\footnotetext{
${ }^{445}$ Helmut Kuhne, Member of the Bundestag (German Parliament), Questionnaire by Vivien Exartier, November 11, 2007

${ }^{446}$ Cowles et al., 8

447 Saalman and Yuan, .3

${ }^{448}$ Andre Brie, German Member of the European Parliament, Interview by Vivien Exartier, Brussels, Belgium, December 18, 2007
} 
unique since there were no such disagreements in the ruling coalitions of France and Britain.

Schröder's argument, according to which lifting the embargo had nothing to do with selling weapons but a lot to do with normalizing relations 16 years after the Tiananmen crackdown, ruffled some feathers in the governing coalition but also in the opposition. ${ }^{449}$ The strong reaction to the possible sale of a nuclear plant to the PRC was an illustration of the perception of China within the German polity. The German Social Democrats' junior coalition partner, the Greens, adamantly opposed lifting the embargo, as did the opposition Christian Democrats. Party leader Claudia Roth demanded that the government reconsider its position and criticized the Chancellor for putting a strain on the cohesion of the EU. To the Greens, the Chinese record for human rights showed more shortcomings than improvements, and the passage of the anti-secession law did not serve the Chinese cause. As a possible remedy, one of the Greens' demands was to beef up the Code of Conduct by making it politically and legally binding ${ }^{450}$. The position of the Greens was, however, made difficult by the fact that one of their high profile members was actually the Minister for Foreign Affairs, Joshka Fischer. Fischer’s position was not entirely clear. On one hand, he told his party he would try to convince the Chancellor to reconsider and on the other hand was still supporting the initiative ${ }^{451}$. Fischer was not recognized as the

\footnotetext{
${ }^{449}$ Gottwald Joern-Carsten “Germany’s China-Policy: Trade Promotion, Human Rights and European Disunity"

in German-Chinese Relations: Trade promotion or something else, eds Overhaus Maro, Sebastian Harnish and Hans Marell, German Foreign Policy in Dialogue, Newsletter-Issue 16, Vol. 6, Trier, Germany, June 23, 2005, 12

${ }^{450}$ Lepping Claudia "Grünes Bündnis mit der Union und den USA, Kanzler soll Waffenembargo gegen China erhalten” Stuttgarter Nachrichten, May 5, 2005, suggested by Alex Bonde, Member of Bundestag

${ }^{451}$ Alex Bonde, Green Party Member of Bundestag, Correspondence with Vivien Exartier, April 1, 2008
} 
spokesperson for its party by other party members ${ }^{452}$. The criticism towards Fischer was not necessarily fair. Firstly, he could not publicly disapprove the Chancellor and secondly ,he himself half-heartedly supported the initiative, declared in several instances that he had an increasingly skeptical attitude, ${ }^{453}$ and that the embargo should only be lifted if Beijing "moves" on human rights concerns and on relations with Taiwan. ${ }^{454}$ The pragmatic approach of the Chancellor did not necessarily match the agenda of the Greens. Could the party or the voters put up with a German foreign policy that ran counter to the Green agenda, but was connected with the party's most well-known figure? This split between ideals and realpolitik could not be good for the party in the long term. ${ }^{455}$

For the CDU, the lift would have sent the wrong signal. The human rights situation in China had improved but not enough to justify a change of course, and the passage of the anti-secession law was another issue ${ }^{456}$. The CDU did not believe in a multipolar world and did not want to alienate the U.S. non-governmental human rights groups who were also displeased by the idea. ${ }^{457}$

The press denounced the contradictions of the rationale for a lift and raised some questions about the place of China in the world. Would the lift really further the integration of China into the international community or contribute to stability in East Asia? The press was particularly adamant on the Taiwanese issue and the blatant

\footnotetext{
452 The Parliament.com “Berlin split over EU’s China arms embargo” April 14, 2005

${ }^{453}$ The Parliament.com "Berlin split over EU’s China arms embargo” April 14, 2005

${ }^{454}$ Dombey Daniel, Raphael Minder, Demetri Sevastapulo and Hugh Williamson. "Pressure mounts as ministers discuss EU embargo on China”, The Financial Times, April 15, 2005

${ }^{455}$ Spiegel International Online "Schroeder Lonely at Home Over China Arms Ban” April 15, 2005 http://www.spiegel.de/international/0,1518,351503,00.html

456 ibid

${ }^{457}$ ibid
} 
human rights abuses in China. ${ }^{458}$ Minister Fisher's ambivalent position on the subject also got literally lots of bad press. The media played a role of 'watchdog' by pointing out the cracks in the foreign policy-making of the governing German coalition foreign policy, especially with upcoming elections.

The country's organizational and policymaking culture, seen as a third mediating factor, also affects whether domestic actors can use adaptation pressures emanating from Europeanization to induce structural change. The episode of the debate of the lift of the arms embargo highlighted the predominance of the Chancellor in foreign policy-making. It is interesting to note that the German Basic Law does not stipulate who or what is the vehicle for the conduct of foreign policy in the German polity. The only stipulation is that "the Federation shall have exclusive legislative jurisdiction in respect of foreign affairs" (article 73). Consequently, the controversy over whether foreign policy is to be regarded as the sole responsibility of the executive or as a competence to be jointly exercised both by the executive and parliament is raised often ${ }^{459}$. The extent to which the Chancellor exercises his constitutional authority and uses it for conducting a consistent foreign policy depends on many factors, ranging from his personality and his ministerial appointments to coalition maintenance and party cohesion. For several years, Germany’s China policy had been the Chancellor's task where the influence of the Foreign Ministry's influence had been reduced and was focusing on economic cooperation. The fast pace of modernization of China and the personality of then Chinese Prime Minister Zhu Rongji impressed the German Chancellor who soon established his office as the

\footnotetext{
${ }^{458}$ ibid

${ }^{459}$ Roberts Geoffrey. “German Politics today”. (Manchester University Press 2000), 19
} 
strategic actor in Germany’s policy vis-à-vis China. The Foreign Ministry did not obstruct the ambitions of the Chancellor, and certainly did not mind leaving the Chancellor responsible for the tricky relationship with the PRC. Bilateral relations have thus reached a great level of political and personal closeness; Schröder visited China six times during his incumbency. Under Schröder leadership, the office of the Chancellor became the main promoter of German trade and left other members of the cabinet with the displeasure of criticizing China for poor human rights records. ${ }^{460}$

Throughout the debate, Chancellor Schröder argued the case that lifting the embargo would economically benefit Germany and went over the objections of his coalition partners; he became a bully by persistently promoting the line to lift the embargo, positioned himself against his own Social Democratic Party (SPD) and against Joschka Fischer, the Foreign Minister and the leader of the junior coalition partner, the Greens. Schröder insisted on several occasions on the predominance of the Chancellor and that irrespective of any voting in the Bundestag, the final authority of foreign policy making laid with the federal government. This kind of stance by Schröder was often termed by the German opposition as Alleingang (go-it-alone policy). ${ }^{461}$ Critics even dubbed Schröder the "Panzer Kanzler" (or "tank chancellor") for his eagerness on the issue. ${ }^{462}$ Schröder's authoritarian style of leadership was decisive to override partners in the governing coalition and within his own party ${ }^{463}$. His assertive personality helped him in international negotiations as he was conscious

\footnotetext{
${ }^{460}$ Gottwald, 9

${ }^{461}$ Rashmi Mukhopadhyay Alok, "EU Arms Embargo on China: The German debate” IDSA Comment, Institute for Defense Studies and Strategic Analysis, (May 2, 2005), http://www.idsa.in/idsastrategiccomments/EUArmsEmbargoonChina_AkMukhopadhyay_020505, 
of the role that a unified and fully sovereign that Germany was playing on the European stage and on the world stage and differently than the early Germany.

The stance on human rights was a key factor to determine how a country would react to the embargo. In the case of Germany, the issue fluctuated between the background or in the forefront. Human rights never seemed the priority of the Chancellor but improving the human rights situation in East Asia was officially a central concern of the Federal Government. Like his predecessor, Schröder claimed that his government was conducting the Human Rights Dialogue with China behind closed doors, rather than in public. Germany continued to voice at the UN Human Rights Commission HR concerns over human rights abuses in China almost on an annual basis. $^{464}$ Joschka Fischer, in his speech to the 61st Session of the United Nations Commission on Human Rights in Geneva in March 2005, depicted the human rights situation in China as a source of concern. ${ }^{465}$ But this strategy seemed to have had very limited success beyond the symbolic release of a small number of political prisoners by the Chinese leadership in advance of state visits. This limited record explained the constant pressure by the Green Party, the opposition and the media towards better results and the general opposition to the lift of the embargo. Even within the Chancellor's own party, there was a consensus that the embargo should be lifted only if the human rights situation improved. The vote to uphold the embargo was initiated by the parliamentary groups that supported Schröder. ${ }^{466}$ The debate in Germany was much more centered on symbolic issues such as human rights

\footnotetext{
${ }^{464}$ Wong (2005), 16

${ }^{465}$ Rashmi "EU Arms Embargo on China"

${ }^{466}$ Kuhne Helmut, Member of the Bundestag (German Parliament), Questionnaire by Vivien Exartier, November 11, 2007
} 
and the timing of the issue. How could Germany have clear conscience selling weapons to China, who had made so little progress inhuman rights? The tone of the debate was not so much about the factual outcome of lifting the embargo. Such a decision would require preparing the public for at least five or six years argued Andre Brie, a German member of European Parliament.

The trade motivation remained the principal explanation to Germany's positive response to further Europeanization of China policy. The pragmatic trade relationship clearly distinguished itself from the political one. In practice it meant avoiding controversies and downplaying criticism of China’s human record. Germany always regarded the PRC as economically and politically more important then and therefore did not want to risk its good relations to Beijing by undermining the OneChina principle or being too critical on human rights. Trade has been a defining issue of Sino-German relations but to public opinion and to other parties, the trade ambition had to have limits boundaries. And in the case of the Hanau nuclear plant and the arms embargo, political parties and public opinion had a clear impact on Schröder’s ambitious trade promotion agenda. The sale of a plutonium plant was not acceptable and neither was the lift of the arms embargo.

Fourth, the empowerment of external actors and learning mattered. The possibility of the lift empowered the USA who strongly opposed the initiative. The general context was certainly not favorable to a lift, ${ }^{467}$ especially based on the nature of the transatlantic relationship at that time due to the Iraq issue. We exposed in previous chapters the reasons why the U.S. opposed the lift of the embargo so vehemently. On the one hand, Congress feared that a better equipped China would

467 Interview with a French Presidency Advisor 
threaten the safety of Taiwan, and on the other hand, there was the fear that American technology or weaponry sold to Europe could leak out and end up again facing American forces in the Asia Pacific region. In February 2005, the U.S. House of Representatives adopted a resolution stating that it deplored increased E.U. sales and moves to lift the embargo, and declaring that those moves "place European security policy in direct conflict with U.S. security interests.” The resolution passed by a vote of 411-3. It warned that, if Europe did not change course, Congress would have to consider "limitations and constraints" on transatlantic defense-industrial ties.

The US lobbying offensive was at its peak in 2005 but originated mostly from Congress rather than the administration. Despite the reservations of the Bundestag about the lift of the embargo, there was a consensus in German diplomacy that there was a lack of understanding in the U.S. about what the arms embargo was about and that there was a certain degree of hypocrisy at play, when the U.S. delivered sensitive technology to China through presidential waivers. ${ }^{468}$ The U.S. became part of the debate but did not necessarily tip the scale in Germany. ${ }^{469}$

Germany was a pace-setter of Europeanization of China policy for almost forty years but Germany's success in China was mostly trade related and the realities of German-Chinese relations often did not live up to the expectations created by the ambitious rhetoric of the German government. The German trade promotion crusade managed to keep human rights critics at bay by allowing policies such as the Dialogue on Human Rights, the creation of the office of a Human Rights Representative that had little effect. Every German policy vis-à-vis China could be

\footnotetext{
${ }^{468}$ Interview with Kuhne

${ }^{469}$ Gottwald, 13
} 
perceived as a way to improve bilateral trade, even foreign cultural affairs. The lift of the embargo fitted that ambition and was the gateway to a more strategic dimension to the relationship. The role of Chancellor Schröder was decisive in bringing the issue to the fore, given a close relationship with the other 'leader' on the initiative, President Chirac of France, and with the Chinese President.

\subsection{Conclusion}

Germany had been a pace-setter of Europeanization of China policy for almost forty years but Germany's success in China was mostly trade related and the realities of German-Chinese relations often did not live up to the expectations created by the ambitious rhetoric of the German government. The German trade promotion crusade managed to keep human rights critics at bay by allowing policies such as the Dialogue on Human Rights, the creation of the office of a Human Rights Representative that had little effect. Every German policy vis-à-vis China could be perceived as a way to improve bilateral trade, even foreign cultural affairs. The lift of the embargo fitted that ambition and was the gateway to a more strategic dimension to the relationship. The role of Chancellor Schröder was decisive in bringing the issue to the fore, given a close relationship with the other 'leader' on the initiative, President Chirac of France, and with the Chinese President. One may argue that traded its habits of pace-setter in the trade area to a more political outfit. The German diplomacy was active in convincing their European partners and the might of the Franco-German engine was expected to conquer. The Franco-German alliance had been successful in major integration initiatives including some foreign policy related 
ones (creation of Franco-German brigade Eurocorps in 1991 or creation of European Council summits in 1974 on the initiative of the French President and the German Chancellor). There was no misfit between a change in EU policy and Germany.

The wheels of the 'Panzer Kanzler' were however, blocked by a strong opposition not only within government coalition ranks, but also by the Conservative Party (in the opposition), the press and public opinion. Despite his supremacy on foreign policy-making, the Chancellor underestimated the diversity of foreign policy within the coalition and in the opposition. There were too many differences and it was then impossible to reach a consensus. The domestic struggle was the Achilles' heel of the German attempt. The more the issue was dragging, the less likely it would be resolved. The year 2005, with the anti-secession law on Taiwan and the pressure by the United States to withdraw the initiative, combined with an election campaign witnessed the slow death of the initiative. Germany had been successful in clearly communicating about preferences uploading at the EU level but neglected the impact of the domestic level. 


\section{Chapter 6}

\section{Conclusion: Was there any European China Policy in the case of the embargo?}

\subsection{Introduction}

To sum up our findings and conclude on the significance of our research, we did need the point of view of the EU institutions themselves. I contacted representatives from the European Council, the European Commission and Members of Parliament (see Appendix): I obtained thirteen positive responses and ten were interviews. I organized the review of the findings and the significance of our study in the following fashion: how did the hypotheses 2 and 3 checked and how significant the influence of the Big Three on EU sanction policy was; how well the theories about domestic responses to Europeanization on community method policies (formerly Pillar 1) by Börzel, Falkner et al. and Cowles et al. applied to foreign policy by reviewing the various veto points.

In a similar fashion as Germany, the EU has experienced a less problematic relationship with China than had Britain and France ${ }^{470}$. Since an EC delegation was established in Beijing in 1988, a political dialogue was started in 1994, and an annual summit began in 1998 (meetings at the ministerial level started in 1995), the EU as an actor began to challenge the traditional dominance of London, Berlin and Paris in Europe's relations with China $^{471}$. Initially though, the development of China-EU relations was progressive. One can identify three periods in EU-China relations ${ }^{472}$. The first period, from 1975 to 1988 is

\footnotetext{
${ }^{470}$ Wong (2005), 11

${ }^{471}$ Wong (2005), 12

${ }^{472}$ Gosset, David. “China and Europe: toward a meaningful relationship”, Perspectives, Published by Overseas Young Chinese Forum, Volume 3, No. 7, Tuesday, December 31, 2002
} 
motivated by business cooperation; the second period 1989-1995, with 1989 as a milestone in the relationship when Europeans strongly condemned the Tiananmen massacre and suspended dialogue with China. Since 1990, the EU has sponsored resolutions critical of the PRC in the UN's Geneva Human Rights Commission. From 1995, the relation shifted from an only economic relation with criticism on political matters to a much more comprehensive and elaborate cooperation. Nineteen Ninety-five marked the beginning of the real European policy towards China.

The Chinese were actually the ones who pointed to the difficulties the government in Beijing had in dealings with the EU and individual member states at the same time. While China was seeking to establish itself as a global and coherent foreign policy power, the EU's foreign policy agenda did not necessarily follow those of its individual member states. There were areas in which the EU was not yet a coherent actor in foreign and security policy, which made it difficult for Brussels to formulate and implement a common position and common policies. Beijing was faced with the dilemma of balancing its policies towards the EU and towards the individual member states. 


\subsection{The case of the embargo: an aberrant or normal issue for EU foreign policy?}

The debate over a common approach to the rise of China has become one of the most controversial and contested issues across the Atlantic and within Europe itself. ${ }^{473}$ The lift of the arms embargo was at the core of it. One may wonder why the issue would provoke so much passion and intrigue whereas the measure itself never had a solid basis in EU law. The embargo was based on a political Declaration on China made by the European Council meeting in Madrid on 26 and 27 June 1989 and was never legally binding. This embargo occurred before the creation of the European Union and before its Common Foreign and Security Policy, which would establish policy later on legal instruments giving expression to CFSP decisions, including embargoes. The arms ban on China then was an 'empty shell', only a political declaration, and there was never a decision to revise its form. ${ }^{474}$ All other sanction measures that pre-dated the creation of new EU legal instruments have either been discontinued or have been renewed and given a different legal form. ${ }^{475}$

The arms embargo on China is unique in this regard. Since it was a political decision, it never fell into the Commission sanctions portfolio. The European Council was the one deciding to review it, not the Commission, which traditionally oversaw the application of sanctions by working with the Council ${ }^{476}$. In its essence, the China sanction policy could only be affected by Member States themselves. From this it can be argued that from a legal perspective there is not one arms embargo against China but a series of member state

\footnotetext{
${ }^{473}$ Sandschenider Eberhard. "Transatlantic Divergences on the Rise of China” p.24 in American and European relations with China: advancing common agendas, ed. David Shambaugh, Gudrun Wacker (Berlin: Stiftung Wissenshaft und Politik, German Institute for International and Security Affairs, 2008), 24

${ }^{474}$ Franz Jessen, DG External Relations, DH 2 (China), European Commission, Interview by Vivien Exartier, European Commission, Brussels, Belgium, May 15, 2008

${ }^{475}$ Interview with Franz Jessen

${ }^{476}$ Interview with Franz Jessen
} 
embargoes established under country laws and regulations. ${ }^{477}$ It ultimately comes down to the fact that once again the Member States have the last word when it comes to foreign policy. The Europeanization of foreign policy regarding China remains more bottom-up and horizontal than top-down. France and Germany, and at some point the UK, based on their close ties with the PRC and their commercial and strategic interests in the region, pushed for the lift, by setting the agenda and influencing other member states. The issue was ,moreover, symbolic and major European countries wanted to send a symbol to return to normalcy to Beijing by lifting the weapons embargo. The lift of the embargo fitted a bigger EU plan visà-vis China. The EU wanted to be China's main partner and supply this huge market with commercial goods and participate in infrastructure projects, such as high-speed trains, civil engineering projects, and the construction of nuclear power plants. ${ }^{478}$

\subsection{Response to the embargo by other member states}

Some member states did not know how to react when the issue was brought up by France and Germany and were certainly not keen on lifting the ban ${ }^{479}$. The Netherlands, Finland, Belgium, Portugal and Sweden voiced concerns over lifting the embargo without significant improvements in China’s human rights. Despite the concerns, the Netherlands and Denmark demonstrated willingness to agree to lift the of the weapons embargo if it was the will of the majority. The opposition parties and public opinion in Northern European countries were strongly opposed to the lift but could bear it as long as significant human rights improvements were noticeable. In January 2004, Prime Minister Blackened, while the Netherlands was the six-month acting EU President, stated that it would be detrimental for

\footnotetext{
${ }^{477}$ Sipri, 11

${ }^{478}$ Kogan, 9

${ }^{479}$ Interview with Franz Jessen
} 
'political and diplomatic relations for the Netherlands' upcoming presidency if they were the only country in favor of maintaining the embargo. ${ }^{480}$ The consensus was that to upgrade the Common Position and beef up the Code of Conduct. ${ }^{481}$

When the U.S. started expressing their opposition to the measure, some member states did start revising their position. The United Kingdom was the first to do so, based on its special relationship with the United States. The new member states, also loyal to the United States and grateful to have joined NATO, would follow. ${ }^{482}$ The creation of the strategic dialogue on Asia between the United States and the EU did not soften the US stance.

\subsection{Comparison of the influence and responses of the Big Three and their impact of bilateral relations.}

Throughout history, while the EU-PRC relationship was evolving, the Big Three the uploaded their policy preferences to promoted their own relationship with China: a the trade relationship for Germany, a political one for France, and the issue of Hong-Kong for the United Kingdom, ${ }^{483}$ no matter what was happening at the EU level.

Although the UK became a foot-dragger on the issue of the embargo, by not putting the issue on the agenda of its EU presidency in the second half of September 2005, the UK still used

\footnotetext{
${ }^{480}$ Kreutz Joakim, 53

Interview with Franz Jessen,

${ }^{481}$ Gerard Quille, Specialist Security and Defence Policy Department, Directorate General External Policies European Parliament, Interview by Vivien Exartier, European Parliament, Brussels, Belgium, December 18, 2007

${ }^{482}$ Annalisa Giannella, Personal representative of the High Representative on Non Proliferation, European Council, Interview by Vivien Exartier, European Council, Brussels, Belgium, May 17, 2008.

${ }^{483}$ Crossick et al. "EU-China Relations, towards a strategic partnership”, European Policy Center Working Paper, July 2005, 36
} 
the Presidency medium to hold bilateral meetings between British and Chinese ministry delegations...

In the questionnaire, I asked whether the bilateral relations helped or harmed in developing a coherent EU China policy. It was established in the previous chapters that big Member States pursued their own interests rather than a EU one. The UK made the choice to abandon the ship, in order not to upset the US and lose them as a partner in its defense sector. Did the French and Germans pursue the greater good, that is the EU one? The vision of a multipolar world fits the aspirations of the EU to become a stronger political player. There was no misfit between the German and French policies on one hand and with the proposed EU policy on the other. The French and the German had a heavily regulated weapons sales export system and a removal of the lift coincided with French ,German and EU interests. Both countries qualified as pace-setters in their readiness for the policy but above all were pace-setters in setting the agenda, formulating the policy and convincing other member states. The greater good was to improve the China EU relationship, which fitted the vision of a multipolar word; the short-term interest for France, Germany and their followers (Italy and Spain were big proponents) was to increase their market share in China. ${ }^{484}$ Since there was no true single common foreign policy, it was easier for member states to upload their state interests through the EU, as Williams illustrated it with Zimbabwe ${ }^{485}$ and Britain or in the case of Chad and France ${ }^{486}$. The British position was very fluid and did impact the outcome. Britain contributed to confirm the second hypothesis that the Big Three had an influence on EU sanction policy. Britain had an influence in maintaining the status quo and favoring the

\footnotetext{
${ }^{484}$ Interview with Annalisa Giannella

485 Williams Paul. "The Europeanization of British Foreign Policy and the Crisis in Zimbabwe”, paper presented at the European Foreign Policy Unit workshop on 'Europeanisation of national foreign policies' London School of Economics, 5 June 5, 2002

${ }^{486}$ Interview with Gerard Quille,
} 
transatlantic bond over rising China and a coherent EU policy. Britain as a big power had the capacity to tip the scale though very discreet and limited lobbying.

Germany, France and the UK undoubtedly played an important role in agenda setting, policy formulation, exchange of ideas with Member States. ${ }^{487}$ The three Member States were key players in the debate and exerted strong influence, but other countries such as Italy were part of that group as well. Its Prime Minister, Silvio Berlusconi, spoke against the embargo on several occasions. ${ }^{488}$

The influence of the Big Three was naturally more important at the European Council level since the EU sanction policy on China was intergovernmental. One of the questionnaire interviewees at the European Parliament, Silvestro Latella, political advisor PSE-secretariat China delegation (group of European socialist parties), estimated that sanction policy was intergovernmental in strategic issues but supranational for economic issues. $^{489}$ As suggested in the introductory chapter, the arms embargo did not qualify as a sanction per se, since it was a declaration, loophole which needed to be addressed by an updated sanction policy vis-à-vis China. ${ }^{490}$

Based on the fact that the decision emanated from the Council and was not legally binding, there was some resentment even within European institutions about repealing the embargo. The European Commission, originally, seemed divided over the review decision. It appeared that the office of Commission President Romano Prodi was more in favor of lifting

\footnotetext{
${ }^{487}$ Tim Boden, Interparliamentary Delegation for non European countries, European Parliament, Interview by Vivien Exartier, European Parliament, Brussels, Belgium, December 17, 2007

Silvestro Latella, political advisor PSE-secretariat China delegation, European Parliament, Interview by Vivien Exartier, Brussels, Belgium, December 18, 2007

${ }^{488}$ Interview with Annalisa Giannella, Interview with Franz Jessen

${ }^{489}$ Interview with Silvestro Latella

${ }^{490}$ Interview with Gerard Quille
} 
the embargo than the Commissioner for External Relations Chris Patten. Following the China summit in October 2003, President Prodi declared that the Chinese request for removing the embargo had a great chance of success, and when the decision about the review of the embargo was taken in December 2003, Prodi officially supported the measure. ${ }^{491}$ During the early months of 2004, Commissioner Pattern and the External Relations office got on board and concluded that the Code of Conduct might be a better method of restricting arms sales to China. $^{492}$

The European Parliament was much more vehement on its opposition. In that case, there was a mismatch with France and Germany. The only democratically elected body never supported the decision to lift the embargo and passed several resolutions stating its opposition; the EP's stance reflected frustration in domestic opposition parties and in the public opinion as already mentioned in Chapter 2, The European Parliament always had a strong human rights culture ${ }^{493}$. The Members of the European Parliament had an issue with the fact that the Code of Conduct was not legally binding and therefore did not really make countries comply with human rights obligations. ${ }^{494}$

\subsection{The place of China in the world and the aspirations of the EU as a global actor}

The last question in the interview was about International Relations and asked about possible increasing role of China in the international security sphere. Annalisa Giannella, Personal representative of the High Representative on Non Proliferation at the European Council, stated that, on her 'campaign' trip in Washington D.C. to convince the US partners,

\footnotetext{
${ }^{491}$ Kreutz, 50

${ }^{492}$ Dickie Mure. "EU seeks to end China arms embargo", The Financial Times, March 17, 2004

493 Andre Brie, German Member of European Parliament / Committee Foreign Affairs, Interview by Vivien Exartier, December 12, 2007

${ }^{494}$ Interview with Silvestro Latella
} 
the embargo was an issue of adequacy in terms of the relationship with the $\mathrm{PRC}^{495}$. The European Union wanted to develop a true partnership, and scrapping the restriction would symbolize the increasingly positive tone of EU-China relations and the role of China in the world. The rapid growth of Sino-European trade has coincided with the development of the European Political union and of a common European political identity. The draft European Security Strategy Paper stated that "a stronger Europe with a common strategic vision is also a Europe capable of consolidating relationships with the other great partners” like China, as "a pillar of the organization of the new world"496. Europe was trying to raise its profile in the region and saw Beijing as an essential counterweight to US dominance in world affairs., ${ }^{497}$

The relationship is also simplified by the fact that China is neither a military threat nor geographically adjacent to Europe. ${ }^{498}$ From the Chinese point of view, the European diplomacy is not confrontational on human rights and respects national sovereignty. Thus, the security concerns that dominate China's relations with Washington do not hinder China's dealings with Europe. ${ }^{499}$ David Shambaugh goes further by identifying the Sino-European relationship as an emerging “axis” in international relations based on three pillars: engaging China through multilateral institutions that enhance its participation in international affairs; intensifying bilateral Sino-European ties; and improving China’s “domestic capacity” to govern. ${ }^{500}$ Both the EU and China aspire to play a greater role in international affairs, and both promote a multipolar world, each representing one pole.

\footnotetext{
${ }^{495}$ Interview with Annalisa Giannella

496 Solana Javier. “A Secure Europe in a Better World: European Security Strategy”, Brussels, December 12, 2003, 25

${ }^{497}$ Bork Ellen “Keep a common front on arms sales to China”. The Financial Times, May 21, 2004

${ }^{498}$ Griffin and Pantucci, 163

${ }^{499}$ Griffin and Pantucci, 163

${ }^{500}$ Shambaugh David. “China and Europe, The Emerging Axis”. Current History, September 2004
} 
The debate about the lift coincided with the 'upgrade' in EU-China relations to a ‘strategic partnership'. The concept implied a smooth relationship and an cooperation in an increasing number of domains, including strategic ones ${ }^{501}$. Over time and especially since 1995, both EU and China agreed that their relation had not only expanded but also deepened The EU Council's secretary-general/high representative Javier Solana added that, as partners, the EU and China had 'significant global strengths, capabilities and responsibilities'. To Solana, China was rapidly emerging as a world leader and positive actor on the global stage’ ${ }^{502}$

The strategic partnership entailed that global solutions could not be found without China. The PRC should play a more important role in international security. It is a global player, member of the UN Security Council and there have been convergences on non proliferation of weapons of mass destruction and on Darfur, Burma or North Korea ${ }^{503}$. The EU believed that by treating China as a respected interlocutor, it could encourage Beijing to act as a partner on issues of global governance. The Chinese, though, saw the embargo as discrimination, and it seemed difficult to expect leadership from China with an EU embargo. The EU also expected Beijing to ratify the International Covenant on Civil and Political Rights, one of the main United Nations human rights treaties, in the near future. ${ }^{~ 504}$ China could not be treated like pariah states such as Burma, Sudan and Zimbabwe, the only other countries subject to EU arms embargoes. The EU leadership admitted there has not been

\footnotetext{
${ }^{501}$ Interview with Annalisa Giannella

${ }^{502}$ Van Kemenade Willem. “ China-EU Issues: 2005-2010, Commonalities, Limitations, Potential” (prepared for XRG China: Developments \& Prospects 2005-2010 Report, European Institute for Asian Studies, HongKong 2006), 10

${ }^{503}$ Interview with Silvestro Latella

${ }^{504}$ Dickie Mure et al. "The EU's bar on selling military equipment to Beijing lacks credibility but Washington believes any change would be irresponsible”, The Financial Times, February 10, 2005
} 
enough progress on human rights but they maintain that China today is a more liberal country than it was in $1989 .{ }^{505}$

In the words of EU External Relations Commissioner Benita Ferrero-Waldner: "Both the EU and China have changed beyond recognition in 30 years and so has our relationship. Our existing trade and economic cooperation agreement simply does not live up to the dynamism of today's partnership. It's time to reflect the vibrancy of our relations with an ambitious new agreement that will help us move to a fully-fledged strategic partnership. ${ }^{506} \mathrm{It}$ was agreed that the meaning of strategic would have to go beyond the traditional definition and encompass a comprehensive partnership including economic and trade relations, civil society exchanges and political relations.

However, despite the fact that the term "strategic partnership" was not defined by the European Union, yet few have questioned the decision to include China as a strategic partner. The EU's objective should be to help China to be a peaceful, stable democratic (although not necessarily in the full Western sense), internationally responsible country, internally consensus seeking and externally multilateral, sharing broadly similar values and goals. The intensification of bilateral ties between EU and China_ as well as between China and individual member states _does not mean either the weakening of EU-US relations or the guarantee that both want to establish a multipolar world. ${ }^{507}$

\footnotetext{
${ }^{505}$ Peel Quentin "Where trade comes before politics", The Financial Times, February 3, 2005

${ }^{506}$ Crossick et al., 32

${ }^{507}$ Crossick et al.,.23
} 


\subsection{Applicability of adaptation theories on foreign policy}

The methodology was innovative by applying theories of adaptation to Europeanization used for community method policies (formerly Pillar 1) to foreign policy. Using Börzel, Falkner et al., and Cowles et al. theories, I intended to see how the three member states of our study would respond to EU rule. The approach was challenging since when it comes to foreign policy, member states are the ultimate decision-makers versus community method policies where member states must comply. The members states influence then the policy formulation at the EU level by uploading their policy preferences. Using Börzel turned out to be easy to transpose to a foreign policy issue given the changing attitude of Britain for example. Britain was first a fence-sitter, "watching” France and Germany take the lead on the issue, wondering if it would correspond to its interests, before it decided to jump on the bandwagon. Then, based on the strong reaction from the United States, Britain became a foot-dragger and ended up tanking the initiative by convincing other member states in the spring 2005 that the timing was not right and by not putting the issue on the agenda of its EU presidency in the second half of 2005. France and Germany were pace-setters from the beginning to the end, and even after 2005, French diplomacy would still bring up the issue while traveling to the region Börzel's classification could apply to other foreign policy cases and translates how member states might change their opinion as an opinion evolves.

The Cowles et al. and Falkner et al. theories were more difficult to transpose to foreign policy since foreign policy does not only follow one type of Europeanization but several. I had to adjust their models to my needs. Mismatch or misfit meant that there was 
either disagreement between a member state and the EU or unreadiness as for pursuing a certain option. Match or fit meant that there was agreement between the Member State policy and the EU proposed policy and readiness (export control regime) to adapt to the new policy. I adjusted the mediating factors to predict and explain the responses of the member states to Europeanization of EU China policy. Their models were complementary to my questionnaire: the importance of external actors was not mentioned in the questionnaire but was brought during interviews and turned out to be an important mediating factor. The model was also a noteworthy tool to test the hypothesis of the influence of the ultimate impact of external factors (H4).

As for future applications in foreign policy, with a reinforced High Representative, We may see more top-down Europeanization of foreign policy and a stronger grip from Brussels. Reinforced European foreign policy institutions will certainly require adjustments in national political and administrative structures. In addition, this 'national adaptation' might well be supplemented by a process of 'identity reconstruction'. The mere presence of the high representative and his service are likely to increase expectations of a common EU policy, thus constraining national policy choices and further enhancing the 'coordination reflex' among capitals. This will matter all the more since the coordination process will henceforth be led by genuine European actors rather than member state Council presidencies $^{508}$. Then, adaptation models such as Falkner et al. or Cowles et al. should be easier to transpose. Let us now review three mediating factors that struck out and were decisive in making the issue fail.

${ }^{508}$ Jonas, 31 


\subsection{The empowerment of external actors}

\subsubsection{The impact of the United States}

The involvement of the US was decisive in sabotaging the initiative of the lift and was another mediating factor to explain the goodness of fit with the policy. The pro-active stance of the US, we might even call the US as an 'external' foot-dragger, confirmed the hypothesis that any policy initiative changing the EU sanction policy on China needs to be approved by the US, whether the lobbying for the proposal was successful or not.

The US animosity was probably underestimated by the Europeans and not necessarily understandable given the US record regarding weapon sales to China. Indeed, the U.S. previously sold both dual use technologies and arms to China ${ }^{509}$. The frenzy about a potential conflict in the Taiwan Strait puzzled the Europeans. The PRC would not engage Taiwan in a war while the island was one of the largest foreign investors in the Chinese economy. The issue seemed more a turf brawl where the US might feel threatened by the emerging SinoEuropean Axis and by the economic and geopolitical rise of China, which might threaten the ability of the U.S. to act as a unique balancing power in the region and marginalizing its regional influence. ${ }^{510}$

Although the arms embargo issue introduced yet another serious dispute into U.S.European relations, it led to the creation of dialogue between the U.S. and Europe to coordinate their policies in Asia and have a strategic discussion about how China

\footnotetext{
${ }^{509}$ Interview with Annalisa Giannella Griffin and Pantucci..166

${ }^{510}$ Wolfe , 2

Griffin and Pantucci, 162
} 
development can contribute to international security. ${ }^{511}$ The EU was the initiator of those forums with a view to avoid further misunderstandings about policies. These dialogues were conducted by the so-called troika, consisting of the senior official in charge of East Asia at the foreign ministry of the incumbent presidency and the ones of the previous and the next presidency. Their interlocutor on the US side was the assistant-secretary of state for AsiaPacific Affairs, Chris Hill. Main themes on the agenda were global issues such as the Middle East, Iran, North Korea, terrorism etc., where the US and the EU have common concerns. The focus was no longer on the lifting of the arms embargo: the proposal had been removed from the EU agenda due to a lack of consensus within the Union. ${ }^{512}$

\subsubsection{Taiwan}

The EU's official policy with regard to Taiwan was consistent with that of the Chinese government's “one-China” principle. On Taiwan, there is no mismatch between France, Germany, Britain, and the EU: they all recognize the government of the People's Republic of China to be the sole legal government of China, they do not acknowledge Taiwan as a sovereign country, and they have no established diplomatic relations with the island. On the other hand, as the EU's third largest trading partner in Asia, Taiwan is an important economic partner; therefore, its interests cannot be completely ignored. The EU's main objective in managing these relationships has been to try balancing economic relations with Taiwan while maintaining good political relations with Beijing. For the most part, the EU has employed a cautious approach toward Taiwan that has caused little friction, but has not been completely without controversy. Following passage by the Chinese government of an anti-secession law directed at Taiwan, the EU Commission voiced its concern over an

\footnotetext{
${ }^{511}$ Griffin and Pantucci, 167

${ }^{512}$ Van Kemenade, 10
} 
explicit reference that was made to the use of "non-peaceful means" to resolve the issue and warned against unilateral action. The Commission stressed that "any arrangement between Beijing and Taipei could only be achieved on a mutually acceptable basis, with reference also to the wishes of the Taiwanese population" (Commission of the European Communities 2005). ${ }^{513}$ The EU; however, did not associate the anti-Secession Law issue with the lift of the arms embargo, unlike the United States. Given the poor record on human rights, the timing of the Chinese was disastrous and showed that the Chinese authorities did not make any connections between the two, and as expected, the Taiwan issue remained more important to the US than EU-China relations, even when it comes to arms sales. Secondly, it is worth noticing that the EU and Member States do no seem too alarmed by the security considerations in the region of Asia when they conceive of their relations with China, since they are not directly involved, which might have explained the neutral reaction at the announcement. ${ }^{514}$ This attitude differs with the US which is involved in the region. ${ }^{515}$

\subsection{A main veto point: The weight of domestic opposition}

Domestic opposition was the other main veto point that tipped the scale in several countries. It seemed that there was almost a consensus among the Member States' governments that the embargo should be reviewed and possibly removed, while the national political oppositions in most of the member states were against the process regardless of political affiliation. For the Big Three, the level of opposition was the most vociferous in Germany, then followed by the UK and somehow under control in France since there was not

\footnotetext{
${ }^{513}$ Glen and Murgo.336

${ }^{514}$ Richard Balme and Brian Bridges. Europe- Asia relations: Building Multilateralism (Basingstoke: Palgrave MacMillan 2008), 137

${ }^{515}$ Balme and Bridges, 139
} 
so much of a public debate. Even though this opened up a chance for debate on EU foreign policy, this divide between those in power (on the "inside") and those in opposition (on the "outside") created a strange political landscape and reinforced the idea of 'democratic deficit' where national voters and citizens had no control whatsoever about the decisions made in Brussels. This criticism was not necessarily fair since most of those decisions were actually taken by Member States themselves and specifically by the Executive Branch. The European Parliament, as the only democratically elected European body could only reject the decision affecting the outcome of the policy since it only had a consultative role in foreign policy. In a sense, the consequence of insider-outsider politics is that the EU acquired a foreign policy but not a debate on foreign politics. This might create a lack of confidence in the EU as a security provider, both among the member states and among the citizens, which would make it harder to implement some of the objectives in the European Security Strategy. ${ }^{516}$

\subsection{The thorny issue of human rights}

The status of human rights was a scale-tipping issue not only within the EU but of course outside the EU. Human rights were a mediating factor that prevented the proponents of the repeal to succeed in their enterprise. The EU showed some progress made by the PRC on this issue, as far as permanent dialogue, participation in some conventions and other benchmarks. Giannella insisted though that 'the West' was expecting some strong signals such as the release of political prisoners from the Tiananmen events, which never materialized $^{517}$.

\footnotetext{
${ }^{516}$ Kreutz, 55

${ }^{517}$ Interview with Annalisa Giannella
} 
The issue was that the embargo has been ineffective in improving human rights. In response, European Member States have ceased to link political and human rights dialogues to possible sanctions on trade or security issues. ${ }^{518}$ The EU has not reached consensus on those issues, whether it is between member states or between institutions. Bilateral relations have then gained ground in the recent period.

Tibet is just one key example key issue that has poisoned political relations between the EU and China. The EU regularly raises the issue of Tibet in its bilateral dialogues with China and has asked for a Chinese ratification of the International Covenant on Civil and Political Rights (ICCPR) as part of the solution. The ratification of the ICCPR and its application to Tibet, and elsewhere in China, is viewed as an important benchmark of progress in the EU-China dialogue. However, despite years of pressure on this issue, the Chinese government has not ratified the covenant, and the EU continues to voice its concerns over religious freedom, cultural rights, and what has been called “ethnic dilution” in Tibet.

\subsection{Conclusion and agenda for future research}

The debate surrounding the arms embargo on China highlighted some important problems regarding the development of EU foreign policy. It also revealed some indication of the potential the EU carries as a political actor. The EU seemed to have a hard time to find a right balance between its economic and security interests in its China policy and struggled to define its own identity, often overshadowed by the Big Three. The Big Three significantly Europeanized the EU China policy through uploading their preferences. At the same time it appears that European countries have not, either individually or collectively, made a systematic assessment about China, or despite their influence on EU institutions, strived to

\footnotetext{
${ }^{518}$ Balme and Bridges, 137
} 
develop a coherent China policy. Thinking about China has been driven by political and commercial considerations rather than an evaluation of the security environment in East Asia and China's place within it. ${ }^{519}$

The Member States of the EU must also recognize the critical importance of speaking with one voice on China. Their habit of focusing on short-term interests has to be questioned. EU Member States, acting together, can play a vital role in bringing progress to China and other developing nations. The Union's soft-power “toolbox" (trade, finance, technical assistance, etc.) should be used to demonstrate to Beijing the importance of regional cooperation and the fact that a strategic partnership with the EU should be a clear "win-win" for both sides. ${ }^{520}$

Furthermore, the European Security Strategy states that strategic concerns and human rights are important objectives for EU foreign and security policy. There is, however, no indication as to which of these two is considered more important. It seems that the EU as a political entity should be able to bring some leadership on conflicting issues characterizing foreign policy, without waiting on indications coming from Member States. Continuing to link the lifting of the arms ban to progress in China’s human rights improvement for instance, will be increasingly difficult to sustain and indeed may become an irritation as the EU begins to implement its comprehensive strategic partnership with China. There is an opportunity, entirely novel that the EU should seize. The fact that the High Representative for Foreign and Security Policy is now the Commissioner for External Relations should indicate how human rights, trade and strategic interests will affect one another.

\footnotetext{
${ }^{519}$ Sipri, 20

${ }^{520}$ Crossick et al., 37
} 
Finally, it would be interesting look at other regions to see whether the EU sided with human rights or trade, or whether the EU chose a pioneering road. In the case of EU leadership in sanctions, it could be interesting to expand our case to others and assess the status of member states' sanctions legislation, investigations and prosecution of alleged noncompliance and enforcement. 


\section{APPENDIX}

\section{Questionnaire}

General Questions

\begin{tabular}{|c|c|c|c|c|c|c|}
\hline & $\begin{array}{c}\text { Strongly } \\
\text { Agree }\end{array}$ & Agree & Neutral & Disagree & $\begin{array}{l}\text { Strongly } \\
\text { Disagree }\end{array}$ & $\begin{array}{l}\text { No Opinion / } \\
\text { Do not Know }\end{array}$ \\
\hline $\begin{array}{l}\text { Should the } \\
\text { European Union lift } \\
\text { the arms embargo } \\
\text { on China? }\end{array}$ & $\mathbb{E}$ & $E$ & & $E$ & $E$ & $E$ \\
\hline $\begin{array}{l}\text { Does any EU } \\
\text { Member State } \\
\text { influence EU China } \\
\text { sanction policy? }\end{array}$ & $E$ & $E$ & & $E$ & $\mathrm{E}$ & $E$ \\
\hline $\begin{array}{l}\text { Would you agree } \\
\text { that the arms } \\
\text { embargo on China } \\
\text { is a necessary } \\
\text { policy? }\end{array}$ & 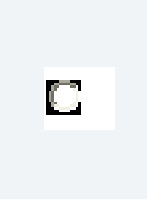 & $E$ & & $E$ & $E$ & $E$ \\
\hline $\begin{array}{l}\text { Is the expression } \\
\text { 'strategic partner' } \\
\text { a good } \\
\text { characterization to } \\
\text { qualify the EU } \\
\text { partnership with } \\
\text { China? }\end{array}$ & $E$ & $E$ & $E$ & $B$ & $E$ & $E$ \\
\hline $\begin{array}{l}\text { Would you agree } \\
\text { that when it comes } \\
\text { to defense and } \\
\text { security issues, } \\
\text { Britain, France and } \\
\text { Germany have the } \\
\text { reputation to play } \\
\text { a significant role in } \\
\text { moving issues in } \\
\text { the European } \\
\text { Union? }\end{array}$ & $E$ & $E$ & $E$ & $B$ & $B$ & $E$ \\
\hline $\begin{array}{l}\text { Would you agree } \\
\text { that the leadership } \\
\text { of one or more } \\
\text { heads of states } \\
\text { within the EU has } \\
\text { been determinant } \\
\text { in the debate to lift } \\
\text { of the arms } \\
\text { embargo on China? }\end{array}$ & $B$ & $E$ & $C$ & 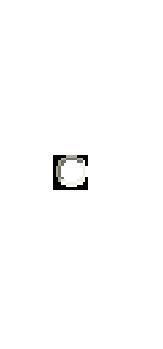 & $B$ & $E$ \\
\hline
\end{tabular}


2. Institutional Questions

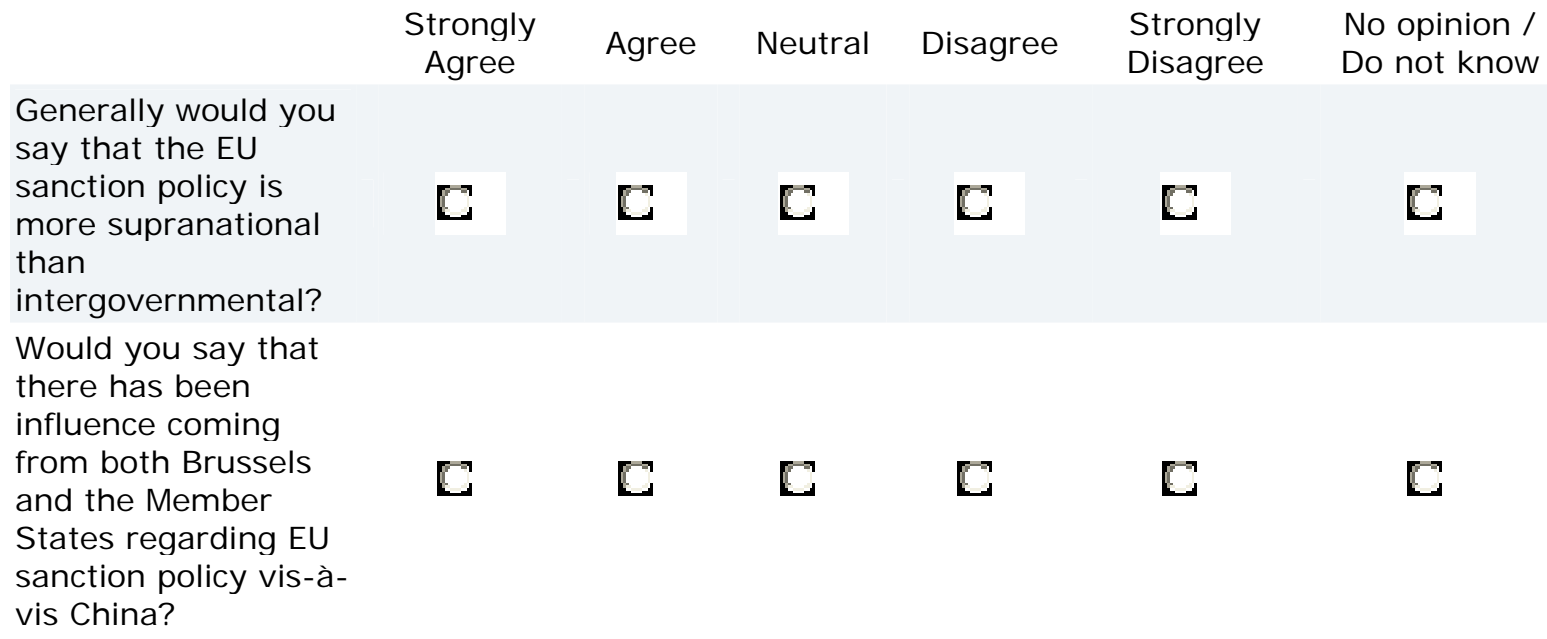

3. Role of EU Member States

Please answer from your office's official perspective.

What kind of

Very Significant Neutral Insignificant Very Don't

Significant Significant Neutral Insignificant Insignificant know

influence does

Britain, France or

Germany have on

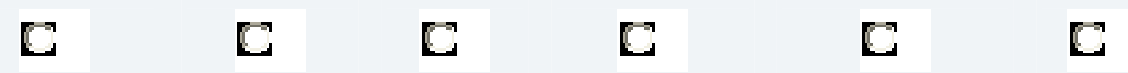

EU China sanction

policy?

What kind of

influence does

Britain, France or

Germany have on

EU Sanction

policy?

What role has

Britain, France or

Germany

generally played

in the debate of

the lift of the arms

embargo in China?

What level of

success has

Britain, France or

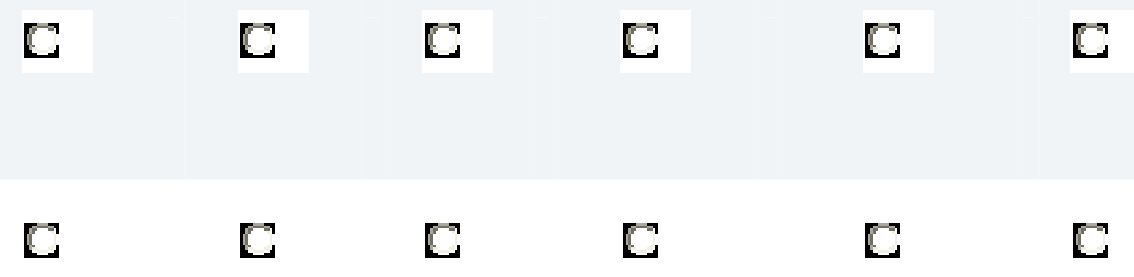


Germany obtained

in having its views

on EU sanction

policy adopted at

the EU level?

What level of

success has the

European Union

obtained in having

its views adopted

C $\quad$ C $\quad$ C $\quad$ C

at the Member

States' level

regarding China

sanction policy?

What level of

success has

Britain, France or

Germany obtained

in communicating

or sharing ideas

C

with other

Member States

regarding EU

China sanction

policy?

What role did

Britain, France or

Germany play in

helping formulate

policies at the EU

C $\quad$ C $\quad$ C

C

C $\quad \mathrm{C}$

level regarding

China sanction

policy?

How significant

has Britain, France

or Germany's

leadership been in

the debate

regarding sanction

policy vis-à-vis

China?

How significant

has the leadership

of Britain, France

or Germany's

head of state been

in the debate to

lift the arms

embargo on

China?

4. Would you agree that France, Britain and Germany have been key players played in the debate to lift the arms embargo on China? 


\section{$\mathbf{C}$ Strongly Agree $\mathbf{C}$ Agree $\mathbf{C}$ Neutral $\mathbf{C}$ Disagree $\mathbf{C}$ Strongly Disagree}

5. If you agree, in which capacity did those states play a significant role?

$\Gamma$ I do not agree with Question \#4. ${ }^{\text {Agenda-setting }} \Gamma$ Policy formulation $\Gamma$ Exchange of ideas with other Member States

6. Bilateral Relations

\begin{tabular}{|c|c|c|c|c|c|}
\hline & $\begin{array}{c}\text { Strongly } \\
\text { Agree }\end{array}$ & Agree & Neutral & Disagree & $\begin{array}{l}\text { Strongly } \\
\text { Disagree }\end{array}$ \\
\hline $\begin{array}{l}\text { Would you agree that } \\
\text { the bilateral relations } \\
\text { of Britain, France or } \\
\text { Germany with China } \\
\text { helped the EU } \\
\text { develop a unified } \\
\text { policy on the PRC? }\end{array}$ & $\mathrm{C}$ & $\mathbb{E}$ & $\mathbb{E}$ & $C$ & C \\
\hline $\begin{array}{l}\text { Would you agree that } \\
\text { Britain, France or } \\
\text { Germany has a } \\
\text { special relationship } \\
\text { with the PRC? }\end{array}$ & $\mathrm{C}$ & $\mathrm{C}$ & $\mathrm{C}$ & $\mathbb{E}$ & $\mathbb{C}$ \\
\hline $\begin{array}{l}\text { Would you agree that } \\
\text { China should play a } \\
\text { more important role } \\
\text { in international } \\
\text { security? }\end{array}$ & $\mathbb{E}$ & $\mathrm{C}$ & 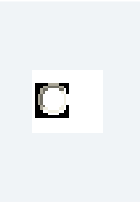 & $\mathbb{E}$ & $\mathrm{E}$ \\
\hline
\end{tabular}




\section{EU Declaration on China Arms embargo - European Council: Madrid, 26-27 June 1989}

The European Council, recalling the declaration of the twelve of June 6, strongly condemns the brutal repression taking place in China. It expresses its dismay at the pursuit of executions in spite of all the appeals of the international community. It solemnly requests the Chinese authorities to stop the executions and to put an end to the repressive actions against those who legitimately claim their democratic rights.

The European Council requests the Chinese authorities to respect human rights and to take into account the hopes for freedom and democracy deeply felt by the population. It underlines that this is an essential element for the pursuit of the policy of reforms and openness that has been supported by the European Community and its member states.

The twelve are aware that the recent events have caused great anxiety in Hong Kong. In the present circumstances the European Council thinks it necessary to adopt the following measures:

- $\quad$ raising the issue of human rights in China in the appropriate international fora: asking for the admittance of independent observers to attend the trials and to visit the prisons,

- $\quad$ interruption by the member states of the community of military cooperation and an embargo on trade in arms with China,

- $\quad$ suspension of bilateral Ministerial and High Level contacts,

- $\quad$ postponement by the community and its member states of new cooperation projects,

- $\quad$ reduction of programmes of cultural, scientific and technical cooperation to only those activities that might maintain a meaning in the present circumstances,

- $\quad$ prolongation by the member states of visas to Chinese students who wish it.

Taking into account the climate of uncertainty created in the economic field by the present policy of the Chinese authorities, the European Council advocates the postponement of the examination of new requests for credit insurance and the postponement of the examination of new credits of the World Bank. 


\section{Table Contacts United Kingdom}

The color code corresponds the following: green means a positive response (correspondence, documents or interview), yellow means a suggestion to another contact, red means not available or not competent, blank means no response.

\begin{tabular}{|c|c|c|}
\hline Name & Position / Affiliation & Status \\
\hline yrossr@parliament.uk & British MEP / Com Foreign Affairs & \\
\hline stuartg@parliament.uk & British MP / Com For Affairs & $11 / 20$ short answer \\
\hline kenpurchasemp@parliament.uk & British MP / Com For Affairs & \\
\hline popegj@parliament.uk & British MP / Com For Affairs & \\
\hline osbornes@parliament.uk & British MP / Com For Affairs & \\
\hline mossm@parliament.uk & British MP / Com For Affairs & \\
\hline mackinlaya@parliament.uk & British MP / Com For Affairs & \\
\hline keetchp@parliament.uk & British MP / Com For Affairs & 12/11 meeting in London / House of Commons \\
\hline illsleye@parliament.uk & British MP / Com For Affairs & \\
\hline horamj@parliament.uk & British MP / Com For Affairs & \\
\hline heathcoat-amoryd@parliament.uk & British MP / Com For Affairs & \\
\hline hamiltonf@parliament.uk & British MP / Com For Affairs & \\
\hline gapesm@parliament.uk & $\begin{array}{l}\text { British MP / Chairman Com Foreign Affairs / House of } \\
\text { Commons }\end{array}$ & no time but attached a speech \\
\hline smithj@parliament.uk & British MP / Com Defense & \\
\hline renniew@parliament.uk & British MP / Com Defense & \\
\hline kevanjonesmp@parliament.uk & British MP / Com Defense & \\
\hline jenkinsb@parliament.uk & British MP / Com Defense & \\
\hline hollowaya@parliament.uk & British MP / Com Defense & \\
\hline havardd@parliament.uk & British MP / Com Defense & \\
\hline portsmouthldp@cix.co.uk & British MP / Com Defense & \\
\hline hamiltonda@parliament.uk & British MP / Com Defense & \\
\hline gilroyl@parliament.uk & British MP / Com Defense & $11 / 12$ too busy \\
\hline Robert Key & British MP / Com Defense & $\begin{array}{l}11 / 12 \text { cannot help me, the Foreign Affairs Com has the lead on } \\
\text { this }\end{array}$ \\
\hline
\end{tabular}




\begin{tabular}{|c|c|c|}
\hline Name & Position / Affiliation & Status \\
\hline crausbyd@parliament.uk & British MP / Com Defense & \\
\hline borrowd@parliament.uk & British MP / Com Defense & \\
\hline arbuthnotj@parliament.uk & British MP / Chairman Defence Com House of Commons & $11 / 13$ too busy \\
\hline timothy.kirkhope@btinternet.com & British MEP / Delegation China & \\
\hline glyn.ford@europarl.europa.eu & British MEP / Delegation China & \\
\hline charles.tannock@europarl.europa.eu & British MEP / Com Foreign Affairs & \\
\hline emma.nicholson@europarl.europa.eu & British MEP / Com Foreign Affairs & \\
\hline richard.howitt@geo2.poptel.org.uk & British MEP / Com Foreign Affairs & 11/9 Email_No 11/22 too busy to meet \\
\hline ratsmep@sir-robertatkins.org & British MEP / Com Foreign Affairs + China delegation & \\
\hline connartym@parliament.uk & British MP / Chairman european scrutiny Committee & \\
\hline baileya@parliament.uk & British MP / Com European Scrutiny & \\
\hline borrowd@parliament.uk & British MP / Com European Scrutiny & \\
\hline clappisonj@parliament.uk & British MP / Com European Scrutiny & \\
\hline William Cash & British MP / Com European Scrutiny & \\
\hline dobbinj@parliament.uk & British MP / Com European Scrutiny & \\
\hline heathcoat-amoryd@parliament.uk & British MP / Com European Scrutiny & \\
\hline mail@greghands.com & British MP / Com European Scrutiny & \\
\hline hillk@parliament.uk & British MP / Com European Scrutiny & \\
\hline hopkinsk@parliament.uk & British MP / Com European Scrutiny & \\
\hline wilsonp@parliament.uk & British MP / Com European Scrutiny & \\
\hline laxtonb@parliament.uk & British MP / Com European Scrutiny & \\
\hline robertsona@parliament.uk & British MP / Com European Scrutiny & \\
\hline yrossr@parliament.uk & British MP / Com European Scrutiny & \\
\hline steena@parliament.uk & British MP / Com European Scrutiny & \\
\hline Name & Position / Affiliation & Status \\
\hline reidj@parliament.uk & MP House of Commons / former Defense Secretary & response $11 / 30$, too busy, suggested to contact Des Browne \\
\hline contact@geoffhoonmp.co.uk & MP House of Commons / former Defense Secretary & \\
\hline camerond@parliament.uk & Leader Conservative Party UK & saw him in DC and gave the letter / questionnaire \\
\hline Tessa Harris & First Secretary RELEX Counselor, UK Rep to the EU & no response \\
\hline
\end{tabular}


Deputy Ambassador Barow

Ambassador Darroch

Jim Murphy

Des Browne

haguew@parliament.uk

Roger Liddle deputy ambassador UKREP

UKREP

Minister for Europe (Gordon Brown Cabinet)

Minister of Defense

Shadow Foreign Secretary / Conservative Party UK sent an email but no response

the asst forwarded my request to Ana Durham

gave a letter to his staffer when he came to Washington

gave a letter to his staffer when he came to Washington 


\section{Table Contacts European Union}

The color code corresponds the following: green means a positive response (correspondence, documents or interview), yellow means a suggestion to another contact, red means not available or not competent, blank means no response.

\begin{tabular}{|c|c|c|}
\hline EUROPEAN UNION & & \\
\hline Name & Position / Affiliation & Status \\
\hline evelyne.gebhardt@europarl.europa.eu & German MEP / Subcom Security And Defense & $\begin{array}{l}\text { 11/28 suggested two contacts Boden and } \\
\text { Latella }\end{array}$ \\
\hline jorgo.chatzimarkakis@europarl.europa.eu & German MEP / Subcom Security And Defense & \\
\hline daniel.cohn-bendit@europarl.europa.eu & German MEP / Subcom Security And Defense & \\
\hline wahlkreisbuero@christian-ehler.de & German MEP / Subcom Security And Defense & \\
\hline alexandergraf.lambsdorff@europarl.europa.eu & German MEP / Subcom Security And Defense & \\
\hline info@wogau.de & German MEP / Chairman Subcom Defense and security & \\
\hline mail@bernd-posselt.de & German MEP / Com Foreign Affairs & \\
\hline tobias.pflueger@europarl.europa.eu & German MEP / Com Foreign Affairs & \\
\hline cem.ozdemir@europarl.europa.eu & German MEP / Com Foreign Affairs & \\
\hline vural.oeger@europarl.europa.eu & German MEP / Com Foreign Affairs & \\
\hline helmut.kuhne@europarl.europa.eu & German MEP / Com Foreign Affairs & $11 / 13$ very detailed answer on his position \\
\hline klaus.haensch@spd.de & German MEP / Com Foreign Affairs & \\
\hline elmar.brok@europarl.europa.eu & German MEP / Com Foreign Affairs & \\
\hline alfred.gomolka@europarl.europa.eu & German MEP / Com Foreign Affairs & \\
\hline michael.gahler@europarl.europa.eu & German MEP / Com Foreign Affairs & \\
\hline André Brie & German MEP / Committee Foreign Affairs & Meeting Brussels $12 / 17$ at $4 \mathrm{pm}$ \\
\hline Gerrard Quille & Specialist Security and Defence Policy Department, EPP & meeting dec 17 \\
\hline Tim Boden & interparlemientary delegation fOr non eur countries & meeting dec 17 \\
\hline Mr Latella & political advisor PSE-secretariat China delegation & \\
\hline Raul Romeva & Spanish MEP / Rapporteur Com. Foreign affairs & meeting january 2008 but need to reschedule \\
\hline Franz Jessen & $\begin{array}{l}\text { DG External Relations, DH } 2 \text { (China), European } \\
\text { Commmission }\end{array}$ & met may 15 \\
\hline \multicolumn{3}{|l|}{ Michalis Rokas } \\
\hline Annalisa Gianella & EC / High Representative Non Proliferation & \\
\hline
\end{tabular}


Ambassador Abou

dietmar.nickel@europarl.europa.eu

jean-luc.dehaene@europarl.europa.eu

\section{Name}

michel.rocard@europarl.eu.int

martine.roure@europarl.eu.int

anne.laperrouze@europarl.europa.eu

jhenin@europarl.eu.int

francis.wurtz@europarl.europa.eu

Helene Flautre

beatrice.patrie@europarl.europa.eu

paulmarie.couteaux@europarl.europa.eu

pmorillon@europarl.eu.int

avatanen@europarl.eu.int
Ambassador to the EU delegation in Beijing

Director for External Relations at the EP

Belgian MEP / Vice Pres China Delegation

Position / Affiliation

French MEP / Com Foreign Affairs

French MEP / Com Foreign Affairs

French MEP / Com Foreign Affairs

French MEP / Com Foreign Affairs

French MEP / Com Foreign Affairs

French MEP / Com Foreign Affairs

French MEP / Com Foreign Affairs

French MEP / Com Foreign Affairs

French MEP / Com Foreign Affairs

MEP / Com Foreign Affairs

\section{oriented me towards Gerrad Quille f}

Status

recommended China delegation

met dec 172007 


\section{Table Contacts France}

The color code corresponds the following: green means a positive response (correspondence, documents or interview), yellow means a suggestion to another contact, red means not available or not competent, blank means no response.

\begin{tabular}{|c|c|c|}
\hline FRANCE & & \\
\hline Name & Position / Affiliation & Status \\
\hline Bureau Hubert Vedrine & Former Minister Foreign Affairs France & meeting 11/22/2007 \\
\hline e.sallenave@senat.fr & Staff Senate Defense Commission & meeting dec 2007 \\
\hline s.dassault@senat.fr & French Senator / Delegation PRC & \\
\hline s.lagauche@senat.fr & French Senator / Delegation PRC / Rapporteur & \\
\hline j.faure@senat.fr & French Senator / Delegation PRC / Vice Chairman & suggested contacted E. Sallenave \\
\hline p.brisepierre@senat.fr & French Senator / Delegation PRC / Vice Chairman & \\
\hline jl.dupont@senat.fr & French Senator / Delegation PRC / Vice Chairman & \\
\hline besson.jean@wanadoo.fr & French Senator / Delegation PRC / Chairman & l'administrateur, Mr Benoît Chadenet au 0142342670 \\
\hline bdepierre@assemblee-nationale.fr & Frenc Representative / My district & meeting sept 12 \\
\hline jp.plancade@senat.fr & French Senator / Vice Pres Com Foreign Affairs and Defense & \\
\hline p.nogrix@senat.fr & French Senator / Vice Pres Com Foreign Affairs and Defense & meeting $12 / 12$ French Senate \\
\hline robert.hue-senat@wanadoo.fr & French Senator / Vice Pres Com Foreign Affairs and Defense & \\
\hline r.delpicchia@senat.fr & French Senator / Vice Pres Com Foreign Affairs and Defense & suggested contacted E. Sallenave \\
\hline m.cerisier-ben-guiga@senat.fr & French Senator / Vice Pres Com Foreign Affairs and Defense & \\
\hline jacques.blanc@senat.fr & French Senator / Vice Pres Com Foreign Affairs and Defense & \\
\hline j.francois-poncet@senat.fr & French Senator / Vice Pres Com Foreign Affairs and Defense & \\
\hline s.vincon@senat.fr & French Senator / Pres Pres Com Foreign Affairs and Defense & \\
\hline Name & Position / Affiliation & Status \\
\hline Chirac Jacques & Former French President / Member Constitutional Council & Recommended Francois R. Elysee + Asie Oceanie Foreign Affairs \\
\hline Douste-Blazy Philippe & Special Advisor Pdt Sarkozy / Former Minister Foreign Affairs France & letter sent, no response \\
\hline Levitte Jean-David & National Security Advisor Pdt Sarkozy / Former Ambassador in China & Meeting with Mr. R. @Elysee 12/12 \\
\hline Marc Abensour & Under director Industrial Issues and Sensitive Exports, Foreign Affairs & \\
\hline Laurent Delahousse & First Secretary French embassy & gave me a few contacts \\
\hline Raffarin J ean-Pierre & Former Prime Minister France / Senator & Letter and email sent, responded recommended me Senator Vallade \\
\hline Pierre Lellouche & French MP / Com Defense & been treying to meet did not work out, one last try this fall? \\
\hline
\end{tabular}




\begin{tabular}{|c|c|c|}
\hline Pierre Selal & Ambassador for French Permanent Delegation in Brussels & $1 / 4 \mathrm{~h}$ d'entretien telephonique durant sejour \\
\hline $\begin{array}{l}\text { pmoscovici@assemblee- } \\
\text { nationale.fr }\end{array}$ & Member of French Parliament & recommended by Michel Rocard, sent an email but no response \\
\hline Christophe Parisot & Counselor RELEX COARM and CODUN & \\
\hline Ambassador Ladsous & French Ambassador to China & \\
\hline christine.roger@diplomatie.gouv.fr & French ambassador to COPS & \\
\hline jean-rene.legoff@diplomatie.gouv.fr & Counselor Armament / COPS & \\
\hline nicolas.demetriades@diplomatie.gouv.fr & Associate Counselor Armament / COPS & \\
\hline Christophe Viprey & DGTPE General Direction of the Treasury and the Political Economy & need to contact him, recommended by Vivet \\
\hline Emmanuel Vivet & French Permanent Representation in Brussels & \\
\hline Jean Louhest & Asst Assoc director Asia Desk / Minsiter for Foreign affairs France & suggested by French embassy in DC, but too busy \\
\hline Louis de Broissia & French Senator / My district & could not meet in September or try December \\
\hline Michelle Alliot-Marie & Minister of Interior France / Former Defense Minister & suggested I send my questions by mail \\
\hline Juppe Alain & & responded that his former chief of staff would get back to me, never did \\
\hline Gerard Bonnardot & Army controller / Advisor to the Pdt of the Defence Committee / French Parl. & meeting 12/14@ National Assembly 3pm \\
\hline Camille Grand & $\begin{array}{l}\text { Director Non Proliferation Ministry Foreign Affairs, Former Advisor Ministry of } \\
\text { Defense }\end{array}$ & met dec 192007 \\
\hline
\end{tabular}




\section{Table Contacts Germany}

The color code corresponds the following: green means a positive response (correspondence, documents or interview), yellow means a suggestion to another contact, red means not available or not competent, blank means no response.

\begin{tabular}{|c|c|c|c|}
\hline & GERMANY & & \\
\hline $\begin{array}{r}\text { Contact } \\
\text { Date }\end{array}$ & Name & Position / Affiliation & Status \\
\hline Dec 4 & Ulrike Merten, SPD & Chairman Defence Com / Bundestag & 8-Mar \\
\hline De 5 & $\begin{array}{l}\text { [D] } \\
\text { Dr. Karl A. Lamers (Heidelberg), } \\
\text { CDU/CSU }\end{array}$ & Vice Chairman Defence Com / Bundestag & 8-Mar \\
\hline 8-Mar & Ulrich Adam $\perp$ & German MP / Defence Com & no too busy \\
\hline 8-Mar & Ernst-Reinhard Beck (Reutlingen) & German MP / Defence Com & \\
\hline 8-Mar & Monika Brüning & German MP / Defence Com & Contact Heinrich Kreft at the CDU/CSU party \\
\hline 8-Mar & $\underline{\underline{\text { Jürgen Herrmann }}}$ & German MP / Defence Com & \\
\hline 8-Mar & Robert Hochbaum & German MP / Defence Com & \\
\hline 8-Mar & Henning Otte & German MP / Defence Com & \\
\hline 8-Mar & Hans Raidel & German MP / Defence Com & \\
\hline 8-Mar & Kurt J. Rossmanith & German MP / Defence Com & \\
\hline 8-Mar & Anita Schäfer (Saalstadt) & German MP / Defence Com & \\
\hline 8-Mar & Bernd Siebert & German MP / Defence Com & \\
\hline & {$[=]$} & & \\
\hline 8-Mar & Rainer Arnold | $\quad *$ ) & German MP / Defence Com & recommended to call Dr. Uwe Stehr for an appointment \\
\hline 8-Mar & Dr. Hans-Peter Bartels & German MP / Defence Com / SPD & \\
\hline 8-Mar & $\begin{array}{l}{[\square]} \\
\text { Petra Heß }\end{array}$ & German MP / Defence Com / SPD & \\
\hline 8-Mar & $\begin{array}{l}\square] \\
\text { Gerd Höfer } \\
\end{array}$ & German MP / Defence Com / SPD & \\
\hline 8-Mar & $\begin{array}{l}\equiv] \\
\text { Rolf Kramer } \\
\end{array}$ & German MP / Defence Com / SPD & \\
\hline 8-Mar & $\begin{array}{l}{[\square]} \\
\text { Ursula Mogg }\end{array}$ & German MP / Defence Com / SPD & \\
\hline & {$[=]$} & German MP / Defence Com / SPD & \\
\hline
\end{tabular}




\begin{tabular}{|c|c|c|c|}
\hline \multirow[b]{2}{*}{ Dec 5} & \multicolumn{2}{|l|}{ Maik Reichel } & \multirow[b]{2}{*}{ 8-Mar } \\
\hline & Jörn Thießen & German MP / Defence Com / SPD & \\
\hline & $\overline{[\overline{[}]}$ & & \multirow[b]{2}{*}{ response $3 / 14$} \\
\hline 8-Mar & Hedi Wegener & German MP / Defence Com / SPD & \\
\hline 8-Mar & $\begin{array}{l}\square] \\
\text { Andreas Weigel }\end{array}$ & German MP / Defence Com / SPD & \\
\hline & ["] & & \\
\hline 8-Mar & Elke Hoff $\perp$ & German MP / Defence Com / FDP & \\
\hline 10-Mar & Birgit Homburger & German MP / Defence Com / FDP & \\
\hline 10-Mar & $\begin{array}{l}\text { [घ] } \\
\text { Dr. Rainer Stinner }\end{array}$ & German MP / Defence Com / FDP & \\
\hline & {$[\overline{[l]}$} & & \\
\hline 14-Mar & Inge Höger & German MP / Defence Com / Die Linke & March 18 Contact Ottfried Nassauer, BITS \\
\hline 14-Mar & Dr. Gesine Lötzsch & German MP / Defence Com / Die Linke & \\
\hline & {$[=]$} & & \\
\hline 14-Mar & Paul Schäfer (Köln) & & long response from a staffer \\
\hline & {$[\square]$} & & \\
\hline 16-Mar & Alexander Bonde | & die grunen & April 1, can send questions and also attached speeches \\
\hline 16-Mar & Winfried Nachtwei & die Grunen & \\
\hline 16-Mar & $\begin{array}{l}\text { [च] } \\
\text { Gert Winkelmeier }\end{array}$ & & \\
\hline & $\overline{[=]}$ & & \\
\hline 16-Mar & Gunther Krichbaum, CDU/CSU & Chairman Affairs of the European Uniion Com & \\
\hline 16-Mar & Kurt Bodewig, SPD & Deputy Chairman & not \\
\hline 18-Mar & Peter Albach & $\mathrm{CDU} / \mathrm{CSU}$ & \\
\hline 18-Mar & Thomas Bareiss & $\mathrm{CDU} / \mathrm{CSU}$ & \\
\hline 18-Mar & Veronika Bellmann & $\mathrm{CDU} / \mathrm{CSU}$ & \\
\hline na & Carl Eduard von Bismarck & $\mathrm{CDU} / \mathrm{CSU}$ & na \\
\hline 18-Mar & Dr. Stephan Eisel & $\mathrm{CDU} / \mathrm{CSU}$ & $4 / 23$ termin \\
\hline 18-Mar & Bernhard Kaster & $\mathrm{CDU} / \mathrm{CSU}$ & 03/19 gave me four contacts: think tanks and scholars \\
\hline 18-Mar & Eduard Lintner & $\mathrm{CDU} / \mathrm{CSU}$ & $3 / 28$ ok for an appointment \\
\hline 18-Mar & Thomas Silberhorn & $\mathrm{CDU} / \mathrm{CSU}$ & \\
\hline & Michael Stübgen & $\mathrm{CDU} / \mathrm{CSU}$ & \\
\hline
\end{tabular}




\begin{tabular}{|c|c|c|c|}
\hline 18-Mar & Hans Peter Thul & $\mathrm{CDU} / \mathrm{CSU}$ & \\
\hline & {$[\equiv]$} & & \\
\hline 18-Mar & Dr. Lale Akgün $\mid$ & SPD German MP / Com Affairs of the EU & contact Gert Weisskirchen Arbeitsgruppe Aussen Polkitik \\
\hline $\begin{array}{r}\text { Contact } \\
\text { Date }\end{array}$ & Name & Position / Affiliation & Status \\
\hline 18-Mar & $\begin{array}{l}\text { [घ] } \\
\text { Clemens Bollen }\end{array}$ & SPD German MP / Com Affairs of the EU & \\
\hline 18-Mar & $\begin{array}{l}=] \\
\text { Hans Eichel }\end{array}$ & SPD German MP / Com Affairs of the EU & \\
\hline 18-Mar & Rainer Fornahl & SPD German MP / Com Affairs of the EU & \\
\hline & $\overline{[\overline{[}]}$ & & \\
\hline 18-Mar & Lothar Ibrügger & SPD German MP / Com Affairs of the EU & 4-11 recommends Wirtschaft und technologie \\
\hline 18-Mar & Josip Juratovic & SPD German MP / Com Affairs of the EU & no was not in office at the time \\
\hline 18-Mar & $\begin{array}{l}{[\mathbf{]}} \\
\text { Steffen Reiche (Cottbus) }\end{array}$ & SPD German MP / Com Affairs of the EU & \\
\hline 25-Mar & $\begin{array}{l}{[=]} \\
\text { Michael Roth (Heringen) }\end{array}$ & SPD German MP / Com Affairs of the EU & \\
\hline & {$[\bar{\square}$} & & \\
\hline 25-Mar & Axel Schäfer (Bochum) & SPD German MP / Com Affairs of the EU & 4-1 ok for a meeting but needs to set it up \\
\hline 25-Mar & Ottmar Schreiner & SPD German MP / Com Affairs of the EU & $\begin{array}{l}\text { 3- } 28 \text { redirected me towards Axel Schaefer europapolitischer } \\
\text { Sprecher der } \\
\text { SPD-Bundestagsfraktion }\end{array}$ \\
\hline 25-Mar & Dr. Martin Schwanholz & SPD German MP / Com Affairs of the EU & \\
\hline NA & Michael Georg Link (Heilbronn) $\perp$ & FDP German MP / Com Affairs of the EU & NA \\
\hline 25-Mar & Markus Löning & FDP German MP / Com Affairs of the EU & $4 / 16$ responded by email and sent some literature \\
\hline 25-Mar & $\begin{array}{l}{[=]} \\
\text { Florian Toncar }\end{array}$ & FDP German MP / Com Affairs of the EU & \\
\hline na & $\begin{array}{l}\text { [三] } \\
\text { Dr. Diether Dehm }\end{array}$ & Die Linke German MP / Com Affairs of the EU & na \\
\hline na & Dr. Hakki Keskin & Die Linke German MP / Com Affairs of the EU & na \\
\hline 25-Mar & Alexander Ulrich & Die Linke German MP / Com Affairs of the EU & \\
\hline
\end{tabular}




\begin{tabular}{|c|c|c|c|}
\hline 25-Mar & Omid Nouripour & DIE GRÜNEN German MP I Com Affairs of the EU & Contact kerstin mueller, spokeswoman for the Greens \\
\hline 25-Mar & Rainder Steenblock & DIE GRÜNEN German MP I Com Affairs of the EU & contact Trittin oder or kerstin mueller \\
\hline 25-Mar & Jürgen Trittin & DIE GRÜNEN German MP I Com Affairs of the EU & \\
\hline 25-Mar & Ruprecht Polenz, CDU/CSU & Chairman Foreign Affairs & \\
\hline 25-Mar & $\frac{\text { Hans-Ulrich Klose, SPD }}{[=]}$ & Vice Chairman Foreign affairs & set up an appoointment, but had to reschedule \\
\hline 25-Mar & Anke Eymer (Lübeck) & CDU / CSU MEP / Com Foreign Affairs & \\
\hline 27-Apr & Erich G. Fritz & CDU / CSU MEP / Com Foreign Affairs & \\
\hline 27-Apr & [ᄆ] & CDU / CSU MEP / Com Foreign Affairs & \\
\hline 27-Apr & Hermann Gröhe & CDU / CSU MEP / Com Foreign Affairs & \\
\hline 27-Apr & $\begin{array}{l}\text { M] } \\
\text { Manfred Grund }\end{array}$ & CDU / CSU MEP / Com Foreign Affairs & \\
\hline 27-Apr & $\begin{array}{l}\text { [-] } \\
\text { Dr. Karl-Theodor Freiherr zu } \\
\text { Guttenberg }\end{array}$ & CDU / CSU MEP / Com Foreign Affairs & \\
\hline 27-Apr & $\begin{array}{l}\equiv] \\
\text { Joachim Hörster } \mid\end{array}$ & CDU / CSU MEP / Com Foreign Affairs & \\
\hline 27-Apr & Eckart von Klaeden & CDU / CSU MEP / Com Foreign Affairs & \\
\hline 27-Apr & $\begin{array}{l}\square] \\
\text { Eduard Lintner }\end{array}$ & CDU / CSU MEP / Com Foreign Affairs & \\
\hline 27-Apr & $\begin{array}{l}=] \\
\text { Ruprecht Polenz } \\
\end{array}$ & CDU / CSU MEP / Com Foreign Affairs & \\
\hline 27-Apr & [] & CDU / CSU MEP / Com Foreign Affairs & \\
\hline 27-Apr & Karl-Georg Wellmann & CDU / CSU MEP / Com Foreign Affairs & \\
\hline 27-Apr & $\begin{array}{l}=] \\
\text { Willy Wimmer (Neuss) }\end{array}$ & CDU / CSU MEP / Com Foreign Affairs & \\
\hline 27-Apr & $\begin{array}{l}{[\overline{[}]} \\
\text { Niels Annen } \mid\end{array}$ & SPD German MP / Com Foreign Affairs & \\
\hline 27-Apr & Detlef Dzembritzki & SPD German MP / Com Foreign Affairs & \\
\hline & {$[\equiv]$} & & \\
\hline 27-Apr & Monika Griefahn & SPD German MP / Com Foreign Affairs & 4-28 response \\
\hline
\end{tabular}




\begin{tabular}{|c|c|c|c|}
\hline 27-Apr & $\begin{array}{l}{[\equiv]} \\
\text { Brunhilde Irber }\end{array}$ & SPD German MP / Com Foreign Affairs & \\
\hline 27-Apr & $\begin{array}{l}\text { [[] } \\
\text { Johannes Jung (Karlsruhe) }\end{array}$ & SPD German MP / Com Foreign Affairs & \\
\hline & 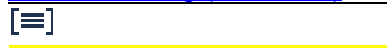 & & \\
\hline 27-Apr & Hans-Ulrich Klose & SPD German MP / Com Foreign Affairs & meeting set up, could not go, refused phone interview \\
\hline 27-Apr & Markus Meckel & SPD German MP / Com Foreign Affairs & \\
\hline 27-Apr & $\begin{array}{l}\text { [ᄆ] } \\
\text { Dr. Rolf Mützenich }\end{array}$ & SPD German MP / Com Foreign Affairs & \\
\hline 27-Apr & $\begin{array}{l}=] \\
\text { Johannes Andreas Pflug }\end{array}$ & SPD German MP / Com Foreign Affairs & \\
\hline 27-Apr & [-] & SPD German MP / Com Foreign Affairs & \\
\hline 27-Apr & $\begin{array}{l}{[\square]} \\
\text { Dr. Ditmar Staffelt } \\
\end{array}$ & SPD German MP / Com Foreign Affairs & \\
\hline 27-Apr & $\begin{array}{l}=] \\
\text { Gert Weisskirchen (Wiesloch) }\end{array}$ & SPD German MP / Com Foreign Affairs & \\
\hline 27-Apr & $\begin{array}{l}\text { [D] } \\
\text { Uta Zapf } \\
\end{array}$ & SPD German MP / Com Foreign Affairs & Johannes Pflug verantwortlich fir china \\
\hline 27-Apr & $\begin{array}{l}{[\overline{[}]} \\
\text { Dr. Wolfgang Gerhardt } / \\
\end{array}$ & FDP German MP / Com Foreign Affairs & no nicht in Berlin 4/28 \\
\hline 27-Apr & Dr. Werner Hoyer & FDP German MP / Com Foreign Affairs & \\
\hline 27-Apr & Harald Leibrecht & FDP German MP / Com Foreign Affairs & ok to respond, need to send questions \\
\hline 27-Apr & $\begin{array}{l}\square] \\
\text { Marina Schuster }\end{array}$ & FDP German MP / Com Foreign Affairs & \\
\hline 24-Apr & $\begin{array}{l}\text { [-] } \\
\text { Wolfgang Gehrcke } \quad \text { *) }\end{array}$ & Die Linke German MP / Com Foreign Affairs & \\
\hline 27-Apr & Monika Knoche & Die Linke German MP / Com Foreign Affairs & \\
\hline 27-Apr & $\begin{array}{l}{[\square]} \\
\text { Dr. Norman Paech }\end{array}$ & Die Linke German MP / Com Foreign Affairs & \\
\hline 27-Apr & $\begin{array}{l}\overline{\bar{I}}] \\
\text { Marieluise Beck (Bremen) }\end{array}$ & DIE GRÜNEN German MP / Com Foreign Affairs & \\
\hline 27-Apr & Dr. Uschi Eid & DIE GRÜNEN German MP / Com Foreign Affairs & \\
\hline
\end{tabular}




\begin{tabular}{|c|c|c|c|}
\hline 27-Apr & $\begin{array}{l}{[\equiv]} \\
\text { Kerstin Müller (Köln }\end{array}$ & DIE GRÜNEN German MP / Com Foreign Affairs & \\
\hline 15-May & Klara Maria Flint & press section & too short notice, try again \\
\hline 15-May & Valerie Karadelnizli & press section & tried but no response \\
\hline
\end{tabular}




\section{European Union Code of Conduct for Arms Exports}

'European Union Code of Conduct for Arms Exports,' agreed by European Union (EU) Foreign Ministers on 25 May; formally adopted at the EU Council of Ministers, 8-9 June 1998

"The Council of the European Union,

Building on the Common Criteria agreed at the Luxembourg and Lisbon European Councils in 1991 and 1992,

Recognising the special responsibility of arms exporting States,

Determined to set high common standards which should be regarded as the minimum for the management of, and restraint in, conventional arms transfers by all EU Member States, and to strengthen the exchange of relevant information with a view to achieving greater transparency,

Determined to prevent the export of equipment which might be used for internal repression or international aggression, or contribute to regional instability,

Wishing within the framework of the CFSP [Common Foreign \& Security Policy] to reinforce their cooperation and to promote their convergence in the field of conventional arms exports,

Noting complementary measures taken by the EU against illicit transfers, in the form of the EU Programme for Preventing and Combating Illicit Trafficking in Conventional Arms,

Acknowledging the wish of EU Member States to maintain a defence industry as part of their industrial base as well as their defence effort,

Recognising that States have a right to transfer the means of self-defence, consistent with the right of self-defence recognised by the UN Charter,

have adopted the following Code of Conduct...:

\section{Criterion One}

Respect for the international commitments of EU Member States, in particular the sanctions decreed by the UN Security Council and those decreed by the Community, agreements on non-proliferation and other subjects, as well as other international obligations

An export licence should be refused if approval would be inconsistent with, inter alia: 
a) the international obligations of Member States and their commitments to enforce UN, OSCE and EU arms embargoes;

b) the international obligations of Member States under the Nuclear Non-Proliferation Treaty, the Biological and Toxin Weapons Convention and the Chemical Weapons Convention;

c) their commitments in the frameworks of the Australia Group, the Missile Technology Control Regime, the Nuclear Suppliers Group and the Wassenaar Arrangement;

d) their commitment not to export any form of anti-personnel landmine.

\section{Criterion Two}

\section{The respect of human rights in the country of final destination}

Having assessed the recipient country's attitude towards relevant principles established by international human rights instruments, Member States will:

a) not issue an export licence if there is a clear risk that the proposed export might be used for internal repression;

b) exercise special caution and vigilance in issuing licences, on a case-by-case basis and taking account of the nature of the equipment, to countries where serious violations of human rights have been established by the competent bodies of the UN, the Council of Europe or by the EU.

For these purposes, equipment which might be used for internal repression will include, inter alia, equipment where there is evidence of the use of this or similar equipment for internal repression by the proposed end-user, or where there is reason to believe that the equipment will be diverted from its stated end-use or end-user and used for internal repression. In line with operative paragraph 1 of this Code, the nature of the equipment will be considered carefully, particularly if it is intended for internal security purposes. Internal repression includes, inter alia, torture and other cruel, inhuman and degrading treatment or punishment, summary or arbitrary executions, disappearances, arbitrary detentions and other major violations of human rights and fundamental freedoms as set out in relevant international human rights instruments, including the Universal Declaration on Human Rights and the International Covenant on Civil and Political Rights.

\section{Criterion Three}

The internal situation in the country of final destination, as a function of the existence of tensions or armed conflicts

Member States will not allow exports which would provoke or prolong armed conflicts or aggravate existing tensions or conflicts in the country of final destination. 


\section{Criterion Four}

Preservation of regional peace, security and stability

Member States will not issue an export licence if there is a clear risk that the intended recipient would use the proposed export aggressively against another country or to assert by force a territorial claim. When considering these risks, EU Member States will take into account inter alia:

a) the existence or likelihood of armed conflict between the recipient and another country;

b) a claim against the territory of a neighbouring country which the recipient has in the past tried or threatened to pursue by means of force;

c) whether the equipment would be likely to be used other than for the legitimate national security and defence of the recipient;

d) the need not to affect adversely regional stability in any significant way.

\section{Criterion Five}

The national security of the Member States and of territories whose external relations are the responsibility of a Member State, as well as that of friendly and allied countries

Member States will take into account:

a) the potential effect of the proposed export on their defence and security interests and those of friends, allies and other Member States, while recognising that this factor cannot affect consideration of the criteria on respect of human rights and on regional peace, security and stability;

b) the risk of use of the goods concerned against their forces or those of friends, allies or other Member States;

c) the risk of reverse engineering or unintended technology transfer.

\section{Criterion Six}

The behaviour of the buyer country with regard to the international community, as regards in particular to its attitude to terrorism, the nature of its alliances and respect for international law

Member States will take into account inter alia the record of the buyer country with regard to:

a) its support or encouragement of terrorism and international organised crime; 
b) its compliance with its international commitments, in particular on the non-use of force, including under international humanitarian law applicable to international and noninternational conflicts;

c) its commitment to non-proliferation and other areas of arms control and disarmament, in particular the signature, ratification and implementation of relevant arms control and disarmament conventions referred to in sub-paragraph b) of Criterion One.

\section{Criterion Seven}

The existence of a risk that the equipment will be diverted within the buyer country or reexported under undesirable conditions

In assessing the impact of the proposed export on the importing country and the risk that exported goods might be diverted to an undesirable end-user, the following will be considered:

a) the legitimate defence and domestic security interests of the recipient country, including any involvement in UN or other peace-keeping activity;

b) the technical capability of the recipient country to use the equipment;

c) the capability of the recipient country to exert effective export controls;

d) the risk of the arms being re-exported or diverted to terrorist organisations (anti-terrorist equipment would need particularly careful consideration in this context).

\section{Criterion Eight}

The compatibility of the arms exports with the technical and economic capacity of the recipient country, taking into account the desirability that States should achieve their legitimate needs of security and defence with the least diversion for armaments of human and economic resources

Member States will take into account, in the light of information from relevant sources such as UNDP, World Bank, IMF and OECD reports, whether the proposed export would seriously hamper the sustainable development of the recipient country. They will consider in this context the recipient country's relative levels of military and social expenditure, taking into account also any EU or bilateral aid." 


\section{Armament Industry Data}

European Union Arms Export Licences to China, 2001-2004

\begin{tabular}{|l|l|l|l|}
\hline Country / Year & 2002 & 2003 & 2004 \\
\hline France & $€ 105,341,246$ & $€ 171,530,641$ & $168,900,766$ \\
\hline Germany & 10 & $1,096,261$ & 882,890 \\
\hline UK & $76,500,000$ & $112,455,000$ & $147,600,000$ \\
\hline EU Total & $209,794,157$ & $415,820,913$ & $340,664,219$ \\
\hline
\end{tabular}

Source: Stockholm Institute of International Peace http://www.sipri.org/contents/expcon/annrep.html

Major armament companies sales in 2003 and market share from armament only.

Chiffre d'affalres

en 2003 (en milllons de dollars)

\begin{tabular}{|rr|}
\hline Lockheed Martin & 24910 \\
\hline Bosing & 24370 \\
\hline Norttrop Grumman & 22720 \\
\hline BAE Systems & 15760 \\
\hline Raytheon & 15450 \\
\hline Thaneral Dynamics & 13100 \\
\hline Thades EADS & 8350 \\
\hline United Tectnologies, UTC & 6210 \\
\hline Firmeccanica & 5290 \\
\hline
\end{tabular}

Part du chlffre daffalres total tiré de rarmement (en \%)

\begin{tabular}{|c|c|}
\hline If Lockheed Martin & $78,3 \%$ \\
\hline Bosing & $48,3 \%$ \\
\hline Northrop Gumman & $86,7 \%$ \\
\hline 2.S. BAE Systems & $76,7 \%$ \\
\hline Aaytheon & $85,3 \%$ \\
\hline General Dynamics & $78,8 \%$ \\
\hline A. Thales & $70 \%$ \\
\hline FADS & $23,6 \%$ \\
\hline Unitted Technologies, UTC & $20 \%$ \\
\hline Firmeccanica & $56,6 \%$ \\
\hline
\end{tabular}

Source: Sipri, Yearbook 2005 
Top 10 arms exporters, for the period 2005-2009

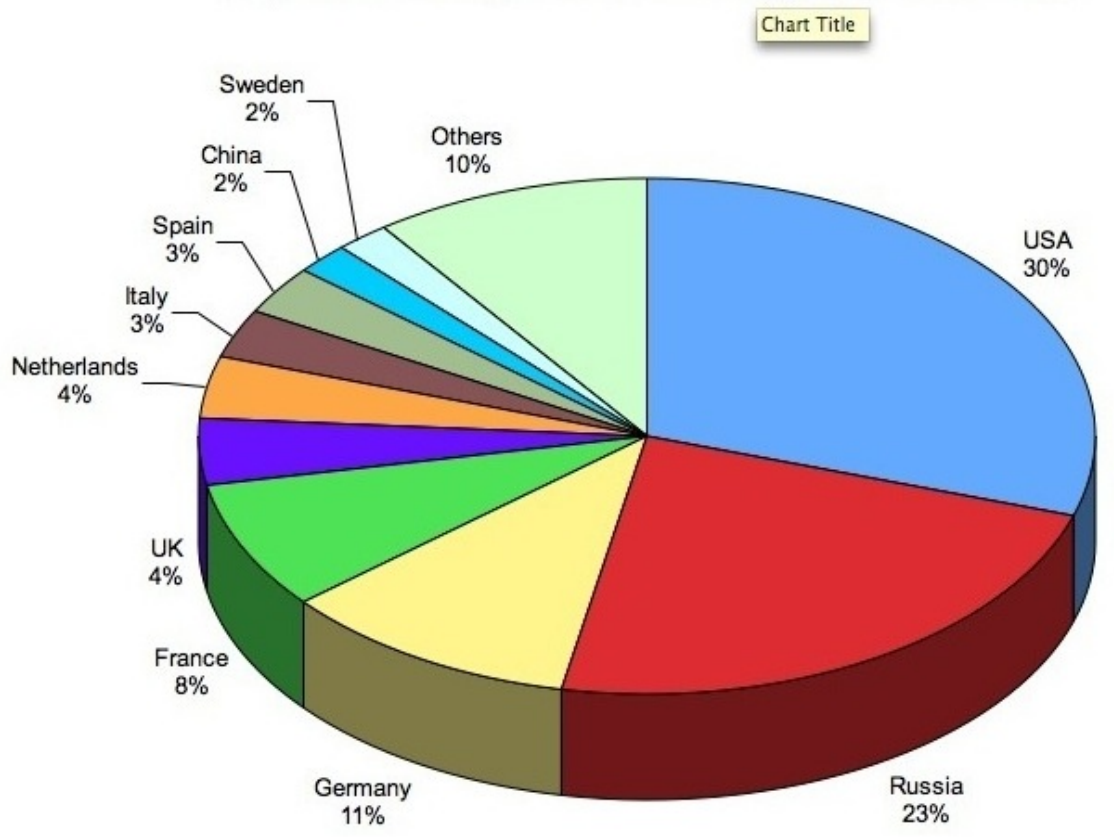

The top 20 arms exporters:

1. USA

2. Russia

3. Germany

4. France

5. United Kingdom

6. Netherlands

7. Italy

8. Sweden

9. China

10. Ukraine

11. Spain

12. Israel

13. Canada

14. Switzerland

15. Poland

16. Uzbekistan

17. South Korea

18. South Africa

19. Belgium

20. Denmark

Source: Stockholm International Peace Institute 


\section{Top 10 arms importers, for the period 2005-2009}

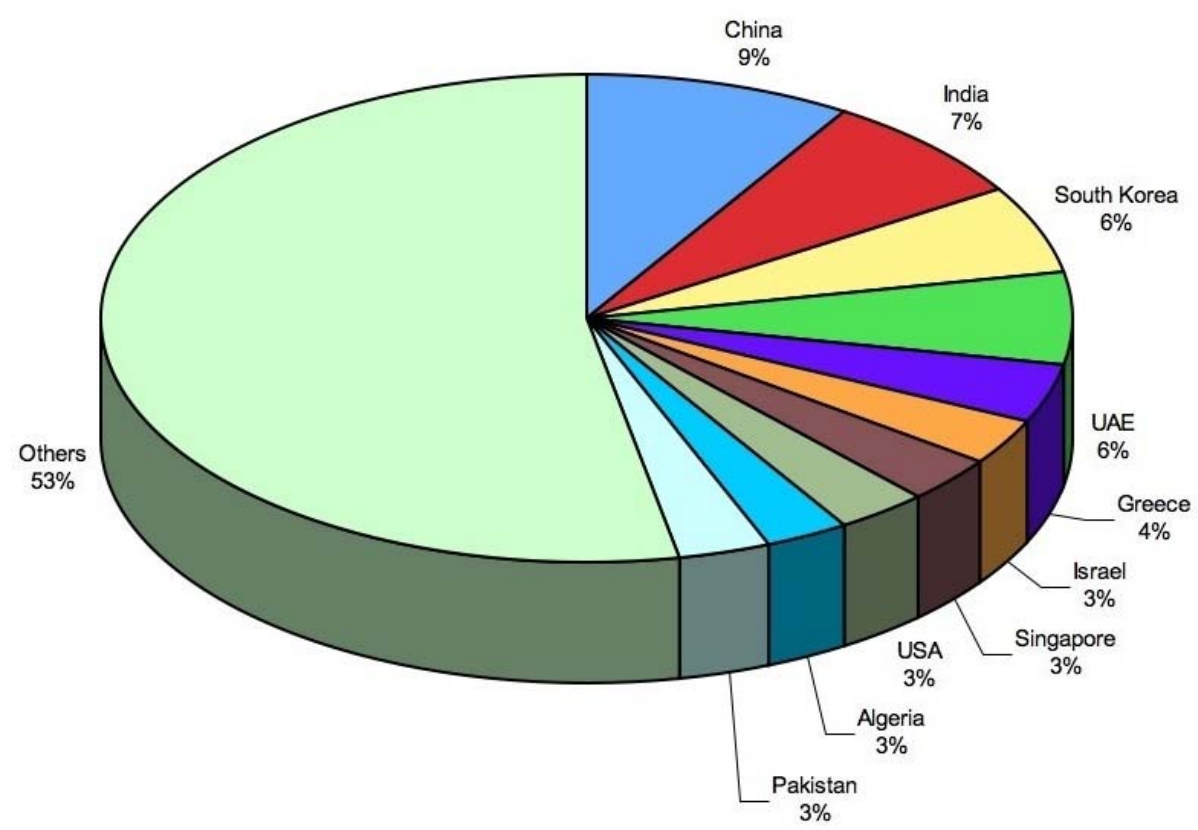

The top 20 arms importers:

1. China

2. India

3. United Arab Emirates

4. Greece

5. South Korea

6. Israel

7. Egypt

8. Australia

9. Turkey

10. USA

11. Pakistan

12. Chile

13. Japan

14. Poland

15. United Kingdom

16. Italy

17. Taiwan

18. Singapore

19. South Africa

20. Spain 


\section{REFERENCES}

Adams Christopher. "UK fears on rights in China”, The Financial Times, November 11, 2004

Adams Christopher and Benoit Bertrand and Daniel Dombey. "Solana to mediate in China arms ban dispute”, Financial Times, March 23, 2005

Adams Christopher "MPs seek assurances over arms to China”, The Financial Times, March 24, 2005

Allen David and Tim Oliver. "The Foreign and Commonwealth Office" in The Europeanization of British Politics, ed. Ian Bache and Andrew Jordan, (Basingstoke: Palgrave McMillian 2006)

Askari Hossein, John Forrer, Hildy Teegen, and Jiawen Yang. Economic sanctions: examining their philosophy and efficacy. (Westport, Connecticut: Praeger), 84

Atkins Ralph and Hugh Williamson. "German exporters beat a path to the China market: Hopes are riding high on the latest trade trip, headed by Chancellor Gerhard Schröder", Financial Times, December 6, 2004

Jordan Amos et al. American National Security, 5th edition. (Baltimore, London: John Hopkins University Press, 1999)

Anselmo Joseph and Douglas Barrie and Robert Wall. "China showdown” Aviation Week (March 6, 2005), p.1

www.asia-europe-network.org “Lifting of China arms embargo rejected again”, December 3, 2006

Austin Greg. “The 1989 China Arms Ban: putting Europe’s position to Congress”. The Foreign policy Centre, (April 2005)

Auswartiges Amt, Federal Foreign Office "Tasks of German foreign policy, East Asia: Japan, South and North Korea, Mongolia, China including Hong Kong and Macao, Taiwan at the beginning of the $21^{\text {st }}$ century”, Berlin, May 2002

www.asia-europe-network.org 'Lifting of China arms embargo rejected again', December 3, 2006

David Baldwin David. “The Sanctions Debate and the Logic of Choice”, International Security, Vol. 24, No 3 (Winter 1999-2000): 80-107 
Balme Richard and Brian Bridges. Europe- Asia relations: Building Multilateralism (Basingstoke: Palgrave MacMillan 2008), 137

Barysh Katinka Embracing the dragon: the EU's partnership with China Charles Grant and Mark Leonard, editors, (London: Centre for European Reform 2005)

BBC News On Line "EU China arms ban 'to be lifted”, January 12, 2005 http://news.bbc.co.uk/go/pr/fr/-/2/hi/uk_news/politics/4167693.stm

BBC News On Line, "Pressure to keep China arms ban” http://news.bbc.co.uk/2/hi/uk_news/politics/4381421.stm, March 25, 2005

BBC News On Line, "Straw attacked on China arms deal”, http://news.bbc.co.uk/2/hi/uk_news/politics/4188017.stm, January 19, 2005

Benoit Bertrand et al.. "Blair backs EU plans for joint defense project”, The Financial Times, September 22, 2003

Bulmer Simon and Claudio Radaelli. “The Europeanization of National Policy”. Queen's Papers on Europeanization, No1 / 2004,

Benoit Betrand and Daniel Dombey. "Schröder thwarted over China arms ban", The Financial Times, October 28, 2004

Benoit Bertrand Benoit and Mark Odell. "Germans hoping for Euros 1bn deals with China”, The Financial Times, December 4, 2004

Berliner Zeitung. 'German Greens Criticize Government Arms Export Report, Urge Restrictive Exports’ Berliner Zeitung, 12 March 2004.

Biscop Sven, “Able and Willing? Assessing the EU's capacity for military action”, European Foreign Affairs Review 9 (2004): 509-527

Blitz James and Daniel Dombey "Straw admits ending EU arms embargo on China will create tension with US”, The Financial Times, January 19, 2005

Boden Tim, Interparlamientary Delegation for non European countries, European Parliament, Interview by Vivien Exartier, European Parliament, Brussels, Belgium, December 17, 2007

Boese Wade, 'EU retains China Arms embargo'. Arms Control Today, January / February 2005. Arms Control Association.

http://www.armscontrol.org/act/2005_01-02/EU_China?print

Stefan Axel Boese, staffer of Axel Schäfer, Bundestag Member, Committee on European Affairs Member, Phone Interview by Vivien Exartier, May 16, 2008 
Börzel Tanja, "Pace-setting, foot-dragging and fence-setting: member states' responses to Europeanization” Journal of Common Market Studies Volume 40. Number 2, (2002): 193214

Alex Bonde, Green Party Member of Bundestag, Correspondence with Vivien Exartier, April 1,2008

Bonnardot Gérard, Army controller / Advisor to the President of the Defense Committee / French National Assembly, Interview by Vivien Exartier, Paris, France, 2007

Bonsignore Enzio and Eugene Kogan. "Fatal attraction: the EU Defence Industry and China”. Military Technology. (June 2005)

Breslin Shaun. "Beyond Diplomacy? UK Relations With China Since 1997”. The British Journal of Politics and International Relations, Vol. 6 Issue 3 (August 2004),

Bretheron Charlotte. and Vogler, J. The European Union as a Global Actor, (London: Routledge 1999), 47

Brie Andre, German Member of European Parliament / Committee Foreign Affairs, Interview by Vivien Exartier, December 12, 2007

Brussels European Council Italian Presidency Conclusions, European Council, December 1213, 2003

Cabestan Jean-Pierre. "Relations between France and China: towards a Paris-Beijing Axis?”. China: An International Journal 4.2 (2006) 327-340, p.328

David Calleo, Rethinking Europe's Future, (Princeton: University Press 2001)

Maria Green Cowles et al. Transforming Europe: Europeanization and Domestic Change. (Ithaca, NY: Cornell University Press, 2001)

Cameron Ross, Perspectives on the Enlargement of the European Union, (Leiden: Brill 2002)

Caruso Raul. "To lift or not to lift? A few notes on the lifting of the European Arms Embargo on China” Crossroads, Vol.5, No 2, (2005), 10

Chen Edwin “Atlantic Divide on China”, Los Angeles Times, February 23, 2005

Ching Frank "Changing dynamics in EU-China arms relations”. The Jamestown Foundation, China Brief, Volume 4, Issue 5 (March 8, 2004)

Chirac Jacques. Press conference given by Jacques Chirac, President of the Republic, Hong Kong, December 10, 2004. http://www.ambafrance-uk.org/Press-conference-given-by$\underline{\mathrm{M}, 4385 . h t m l}$ 
Chirac Jacques, Press conference given by Jacques Chirac, President of the Republic, Hong Kong October 12, 2004

Cowles, Maria Green et al. Transforming Europe: Europeanization and Domestic Change. (Ithaca, NY: Cornell University Press, 2001)

Crossick Stanley, Cameron Fraser and Berkofsky Axel. "EU-China Relations, towards a strategic partnership”, European Policy Center Working Paper, July 2005,

Crawford Beverly. Review of Randall E. Newnham, Deutsche Mark Diplomacy: Economic Linkage in German-Russian Relations in Slavic Review, Vol. 63 no. 2 Summer 2004, pp. 427-28

Dale Reginald, “The search for a Common Foreign Policy”, Europe, Issue 388 (July/August 1999)

Defense Industry Daily, “China Arms Embargo Controversy Will Have Domestic Ripples”, February 28, 2005

Defense News "French renews calls for EU to end China arms embargo", December 12, 2006

Dempsey Judy, "US hits at EU move to lift arms ban on China”, The Financial Times, April 2, 2004

Huband Mark "Arms embargo on China divides defence industry: The next government will come under US pressure to keep the weapons ban during the UK's EU presidency" The Financial Times, April 7, 2005

Dempsey Judy "Big powers back more muscular foreign policy”, The Financial Times, June 12,2003

Dempsey Judy and Katrin Benhold. "Britain lands in middle of U.S.-EU China spat" International Herald Tribune March 23, 2005

Ann Deighton Ann "The European Security and Defense Policy", Journal of Common Market Studies, Vol.40, Number 4, (November 2002): 719-741

Deutsche Welle. „Hu meets Merkel As Germany Reaffirms EU Arms Ban“, November 11, 2005

Dinmore James and James Harding. "Level of US opposition surprises” , The Financial Times, March 22, 2005 
Dinmore Guy and James Harding, "UK seeks support for move to delay lifting of EU's arms ban on China”, The Financial Times, March 22, 2005

Dinan Desmond, Ever closer Union: an introduction to European Integration, (Lynne Rienner Publishers: 1999)

Dombey Daniel, "EU unlikely to lift China arms ban this year", The Financial Times, October 12, 2004

Dombey Daniel and James Blitz "EU doubles arms sales approvals to China”, The Financial Times, January 19, 2005

Dombey Daniel and Peter Spiegel "Up in arms: why Europe is ready to defy the US and lift its weapons ban on China,” The Financial Times, February 10, 2005

Dombey Daniel and Raphael Minder. "Positions unmoved on China embargo", The Financial Times, March 24, 2005.

Dombey Daniel and Stephen Fidler, “Top US official rejects Straw's attempt to ease tension over China arms embargo”, The Financial Times, January 20, 2005

Dombey Daniel, "EU finalises plan to lift arms embargo on China”, The Financial Times, February 3, 2005

Dombey Daniel, "EU considers binding rules on arms sales", The Financial Times, April 18, 2005

Dombey Daniel, Raphael Minder, Demetri Sevastapulo and Hugh Williamson. "Pressure mounts as ministers discuss EU embargo on China”, The Financial Times, April 15, 2005

Dover Robert. Europeanization of British Defence Policy, (Burlington, VT.: Ashgate, 2007)

The Embassy of the People's Republic of China in New Zealand "China, UK vow to develop strategic partnership: joint statement”, December 5, 2004

Esslin M.J. . "East Germany: Peking-Pankow Axis?” The China Quarterly, No. 3 (Jul. - Sep., 1960): $85-88$

Euractiv.com "EU Security and Defence Policy”, Policy Summary, last modified January 5, 2006

http://www.euractiv.com/Article?tcmuri=tcm:29-117486-16\&type=LinksDossier

European Council “Conclusions Seven EU-China summit”, the Hague, December 8, 2004

European Council, Brussels European Council Italian Presidency Conclusions, December 1213, 2003 
Eur-Lex, Official Journal of the European Union "Sixth Annual Report according to Operative Provision 8 of the European Union Code of Conduct on Arms Exports", (2004/C 316/01) 21 December 2004

European Report. “EU/China: MEPs reject French pleas over arms ban.” December 20, 2003

European Report. “EU/China: ministers mull lifting arms ban”. January 28, 2004

European Report. “Arms ban drops off agenda for Hu’s European tour.” November 11, 2005.

European Commission. "Speaking with one voice: Overview", http://europa.eu/pol/cfsp/index_en.htm

European Commission. "Sanctions or restrictive measures"

http://ec.europa.eu/external_relations/cfsp/sanctions/index_en.htm

European Community. Treaty of Rome, March 25, 1957

European Navigator, multimedia digital library on the history of Europe, http://www.ena.lu/

European Union Council Secretariat. "Basic Principles on the Use of Restrictive Measures (Sanction)”, Brussels, June 7, 2004

European Union Council. "Brussels European Council Presidency Conclusions”, December 12-13, 2003

European Council, “Helsinky European Council Summit:Presidency Conclusions”, Helinski, Finland: December 10-11, 1999

European Union Council "A Secure Europe in a better world, European Security Strategy", Brussels, 12 December 2003, CFSP web site http://ue.eu.int/uedocs/cmsUpload/78367.pdf (2003)

European Report “Most member states opposed to lifting arms embargo", December 12, 2006

Jenny Fairbrass, “The Europeanization of business interest representation: UK and French firms compared”, Comparative European Politics, 1 (3) (2003) 313-334

Federal Foreign Office, "East Asia_Japan, South and North Korea, Mongolia, China including Hong-Kong and Macao Taiwan_ at the beginning of the $21^{\text {st }}$ century", Tasks of German foreign policy, Auswärtiges Amt (German Foreign Ministry Archives), Berlin, (May 2002), 7 
Fidler Stephen, Parker George and Frederick Studemann. UK expects Brussels to lift China arms ban, The Financial Times, January 13, 2005

Financial Times reporters "China arms embargo moves off EU agenda, The Financial Times, November 9, 2005

François-Poncet Jean, Monique Cerisier-ben Guiga and Robert del Picchia, Senators. 'Relations Transatlantiques : quelles perspectives pour le second mandat du President Bush' (Transatlantic Relations : what perspectves for the second term of President Bush ?). French Senate Joint Foreign Affairs and Defence Committee, Rapport no 307, April 14, 2005. 20042005.

Falkner, Gerda, Oliver Treib, Miriam Hartlapp and Simone Leiber Complying with Europe: EU Harmonization and Soft law in the Member States Cambridge: University Press 2005

Fierke, K.M. and Antje Wiener. "Constructing institutional interests: EU and NATO enlargement", Journal of European Public Policy, Volume 6, Number 5, 2, (December 1999): 721-744, 726

Foreign and Commonwelath Office, Response to Questionnaire by Vivien Exartier, August 15, 2008

France, Presidency of the Republic. "Dinner with President Bush at the US embassy in Belgium”, Brussels February 21, 2005

France, Ministry of Foreign Affairs "Official visit of the Chinese Prime Minister (December 4-7, 2005)”, http://www.diplomatie.gouv.fr/en/article-imprim.php3?id_article=2989

France, Ministry of Defense, Rapport au Parlement sur les Exportations d'Armement de la France en 2002 et 2003, 28 January 2005

Franco-British Summit, Joint Declaration on European Defense, (St Malo: December 4, 1998)

Frankel Glenn “EU wavers on allowing arms sales to Beijing, Washington Post”, March 23, 2005

Fraser Cameron "What They Said: Fraser Cameron on CFSP, ESDP and the Balkans", Europe, Issue 397, (June 2000)

French Ministry of Defence. Report to the Parliament on France armament exports in 2004.

French Ministry of Foreign Affairs Official visit of the Chinese Prime Minister (December 47, 2005). www.diplomatie.gouv.fr/en/article-imprim.php3?id_article=2989 
French Ministry for Foreign Affairs. Statement of the Spokesperson of the French Ministry for Foreign Affairs. December 6, 2004.

Annalisa Giannella, Personal representative of the High Representative on Non Proliferation, European Council, Interview by Vivien Exartier, European Coucil, Brussels, Belgium, May 17, 2008.

Glen Carol and Richard C. Murgo "EU-China relations: balancing political challenges with economic opportunities”, Asia Europe Journal (2007) 5:331-344

Gottwald Joern-Carsten "Europe and China: Convergence, Politicization and Assertiveness", East Asia (2010) 27:79-97

Gottwald Joern-Carsten “Germany’s China-Policy: Trade Promotion, Human Rights and European Disunity” in German-Chinese Relations: Trade promotion or something else, eds Overhaus Maro, Sebastian Harnish and Hans Marell, German Foreign Policy in Dialogue, Newsletter-Issue 16, Vol. 6, Trier, Germany, June 23, 2005

Gaspers Jan. 'Europeanization of British Defence Policy by R. Dover’

German -Foreign- Policy.com. "Background Report: Strategic Partnership and Containment” January 5, 2004, http://www.german-foreign policy.com/en/fulltext/40108?PHPSESSID=i6ug0kg390914k0sjmr5grchv3

German-Foreign-Policy.com “Strategic Maneuvers German Foreign Policy” March 20, 2004

Ginsberg Roy. The European Union in International Politics: Baptism by Fire, (Lanham MD: Rowman and Littlefield 2001)

German Ministry for Foreign Affairs, "Bilateral relations with China" http://www.diplo.de/diplo/en/Laenderinformationen/01-Laender/China.html

Glenn John, "From Nation-States to Member States: Accession Negotiations as an Instrument of Europeanization”, Comparative European Politics 3-28, (2004)

Godement Francois. “Europe’s second thoughts on China Embargo”. YaleGlobal (March 25), 200

Grabbe Heather, "How does Europeanization affect CEE governance? Conditionality, Diffusion and Diversity, Journal of European Public Policy Vol 8, Issue 4, (December 2001): 1013-1031

Grand Camille, Director Non Proliferation Ministry Foreign Affairs, Former Advisor Ministry of Defense, Interview by Vivien Exartier, French Ministry for Foreign Affairs, Paris, December 18, 2007 
Gueldry Michel "France and European Integration: toward a transnational polity”, (Westport: Praeger 2001)

Grant Charles, Ulrike Guerot. “A military plan to cut Europe in two”, The Financial Times, April 17, 2003

Griffin Christopher and Raffaello Pantucci. "A treacherous triangle? China and the transatlantic alliance”. SAIS Review Vol XXVII no 1 (Winter-Spring 2007)

Grimmett Richard and Theresa Papademetriou. “European Union’s Arms Control Regime and Arms Exports to China: Background and Legal Analysis”. CRS (Congressional Research Service) Report for Congress, March 1, 2005

Hansen Fred Ketil and Axel Borchgrevink. "Cutting aid to promote peace and democracy? Intentions and effectiveness of aid sanctions" The European Journal of Development Research, Vol. 18, No 4 (December 2006): 622-641

Heritier A. 'Leaders' and 'Laggards' in European Clean Air Policy”' in Unger B. and F.V. Waarden (eds) Convergence or Diversity? Internationalization and Economic Policy Response, Aldershot: Avebury

Hill Christopher, The Actors in Europe’s Foreign Policy, London, (Routledge 1996)

Hill John “China arms ban hinders developing Sino-EU relations”. Jane's Intelligence Review (June 2005)

Hill Christopher. "Putting the world to rights: Tony Blair's foreign policy mission" in The Blair Effect 2001-5,_ed. by Anthony Seldon and Dennis Kavanagh, (Cambridge: University Press 2005)

Hix Simon and Goetz Klaus. "Introduction: European Integration and National Political Systems" in Europeanised Politics? European Integration and National Political Systems edited by Goetz Klaus, Hix Simon, pp 1-26 (Frank Cass Publishers 2001)

Horton Frank and others (eds). Comparative Defense Policy, (Baltimore: Johns Hopkins University Press 1974)

Huband Mark "Arms embargo on China divides defence industry: The next government will come under US pressure to keep the weapons ban during the UK's EU presidency" The Financial Times, April 7, 2005

Hufbauer Gary Clyde and Jeffrey J. Schott, assisted by Kimberly Ann Elliott Economic Sanctions Reconsidered: History and Current Policy (Washington, D.C.: Institute for International Economics, 1985), (Cambridge: MIT Press, 1985) 
Irondelle Bastien. (2001) "Europeanization without European Union? French military reforms 1991-1996" . (In European Union Studies Association (EUSA) Biennial Conference 2001 (7th), May 31-June 2, 2001), Madison, Wisconsin

Jessen Franz, DG External Relations, DH 2 (China), European Commission, Interview by Vivien Exartier, European Commission, Brussels, Belgium, May 15, 2008

Jonas Paul "EU Foreign Policy After Lisbon: Will the New High Representative and the External Action Service Make a Difference?” Report Center for Applied Policy Research $(\mathrm{C} \cdot \mathrm{A} \cdot \mathrm{P})$, No 2, June 2008

Keetch Paul, Liberal Party Member of Parliament, Interview by Vivien Exartier, House of Commons, London, UK, December 10, 2007

Peking Teresa Poole "Kinkel goes fence-fixing in China”, The Independent, October 23, 1996

Knill Christoph and Dick Lehmkuhl. "How Europe matters: different mechanisms of Europeanization, European Integration online Papers (EIoP), Vol. 3, No. 7, (June 15, 1999)

Kogan Eugene. "The European Union Defense Industry and the Appeal of the Chinese Market”. Report, Studien und Berichte zur Sicherheitspolitik, Schriftenreihe der Landesverteidigungsakademie, January 2005.

Kohlmeier Gabrielle "EU eyes lifting China arms embargo" Arms Control Today, (September 2004)

Kreutz Joakim. "Hard measures by a Soft Power? Sanctions Policy of the European Union 1981-2004”. Bonn International Center for Conversion, Paper 45, Bonn, 2005, 40.

Kreutz Joakim. "Reviewing the arms embargo on China: the clash between value and rationale in the European Security Strategy". Perspectives: The Central European Review of International Affairs 22, (Summer 2004): 43-58,

Kuhne Helmut, Member of the Bundestag (German Parliament), Questionnaire by Vivien Exartier, November 11, 2007

Kurzer Paulette "Review: Comparative views of Europe”, International Studies Review, Vol. 4, No. 1 (Spring, 2002), pp. 182-186

Latella Silvestro, political advisor PSE-secretariat China delegation, European Parliament, Interview by Vivien Exartier, Brussels, Belgium, December 18, 2007

Linsdsey Daryl “A transatlantic Crisis foretold” Spiegel Online, March 18, 2005 
Major Claudia. "Europeanization and Foreign and Security Policy_Undermining or Rescuing the Nation State?” Politics: 2005, Vol. 25 (3): .175-190

Maull Hans “Editorial” in "German-Chinese Relations: Trade promotion or something else”, ed. Overhaus Maro, Sebastian Harnish and Hans Marell. German foreign policy in dialogue, Newsletter-Issue 16, Vol. 6, Trier, Germany, June 23, 2005

McGowan Lee. "Europeanization unleashed and rebounding: assessing the modernization of EU cartel policy”, Journal of European Public Policy 12:6, (December 2005): 986-1004

McLean Elena and Tahee Wang. "Friends and Foes? Major trading partners and the success of economic sanctions”. International Studies Quarterly (2010) 54: 427-447

McKenna Ted. Euro Parliament favors China Arms Ban. The Journal of Electronic Defense, June 2005.

McKenna Ted. Controversy Dogs EU-China Arms Ban. The Journal of Electronic Defense, March 2005.

Military Photos.net. 'France backs lifting of China arms embargo'. www.militaryphotos.net/forums/showthread.php?t=29388, December 9, 2004

Möller, Kay. "Diplomatic Relations and Mutual strategic Perceptions: China and the European Union”. The_China_Quarterly: 196, March 2002, Special Issue: China and Europe since 1978: a European Perspective

Moore Matthew. "Arming the embargoed: a supply-side understanding of arms embargo violations”. Journal of Conflict Resolution 54 (4): 593-615, (2010), 593

Moskos Charles, Jr.. “The Military”.Annual Review of Sociology, Vol. 2, 1976 (1976), 55-77

Muller-Brandeck-Bocquet Gisela "The new CFSP and ESDP Decision-Making System of the European Union”, European Foreign Affairs Review 7: 257-282, (2002)

Mure Dickie. “EU seeks to end China arms embargo”, The Financial Times, March 17, 2004

Mure Dickie, Guy Dinmore, Daniel Dombey, Kathrim Hille, Demetri Sevastapulo and Peter Spiegel. "The EU's bar on selling military equipment to Beijing lacks credibility but Washington believes any change would be irresponsible”, The Financial Times, February 10, 2005

Murray Douglas and Paul Viotti. The Defense Policies of Nations: a comparative study, Third edition, (Baltimore: The Johns Hopkins University Press, 1994

Newman Cathy, "Brown backs EU on arms sales to China”, The Financial Times, February 22, 2005 
Newman Cathy "Howard attacks moves to lift China arms ban” The Financial Times, March 31, 2005

Nouvelles Atlantiques. UE/Armements: vers de nouvelles regles communes de controle des exportations d'armes', no3693, July 5, 2005

Olsen Johan. “The many faces of Europeanization”, Arena Working Papers WP 1/2, Center of European Studies, University of Oslo, (2002), pp.2-3

Pagedas Constantine "Post-Ismay Europe: Britain and the Rebalance of European Security", Mediterranean Quarterly, (12-4, 2001), 8

Pape Robert “Why economic sanctions do not work”. International Security, Vol. 22, No2, (Fall 1997): 90-136

Parker George and Daniel Dombey. “Dual ambitions”, The Financial Times, May 24, 2002

Parker George, "EU team moots building foreign policy under one minister”, The Financial Times, (April 15, 2003)

Peel Quentin “Where trade comes before politics” , The Financial Times, February 3, 2005

People’s Daily Online “China, Britain hold strategic security consultations” October 21, 2003.

Peking Teresa Poole "Kinkel goes fence-fixing in China”, The Independent, October 23, 1996

Piana Claire, “The EU's Decision-Making Process in the Common Foreign and Security Policy: the Case of the Former Yugoslav Republic of Macedonia”, European Foreign Affairs Review 7: 209-226, (2002)

Pozzo di Borgio Cecile, Spokesperson of the French Ministry for Foreign Affairs. Agence France Presse Statement, December 7, 2004.

Presidential Advisor, French Presidency, Interview by Vivien Exartier, Elyséee Palace, Paris, France, December 18, 2007

Gerard Quille, Specialist Security and Defence Policy Department, Directorate General External Policies European Parliament, Interview by Vivien Exartier, European Parliament, Brussels, Belgium, December 18, 2007

Ramirez Luis. "China arms embargo outdated, French foreign says" Voices of America, Beijing, April 21, 2005. 
Rashmi Mukhopadhyay Alok, "EU Arms Embargo on China: The German debate” IDSA Comment, Institute for Defense Studies and Strategic Analysis, (May 2, 2005) http://www.idsa.in/idsastrategiccomments/EUArmsEmbargoonChina_AkMukhopadhyay_02 $\underline{0505}$

Rennie David “Crisis over plan to end China arms embargo”, The Telegraph, February 23, 2005

Roberts Geoffrey. “German Politics today”. (Manchester University Press 2000)

Rometsch Dietrich and Wolfgang Wessels, eds. "The European Union and Member States: towards Institutional Fusion?”, European Policy Research Unit Series, (Manchester :University Press 1996), 329

Saalman Lora, Yuan Jing-Dong. “The European Union and the Arms Ban on China”. Center for Non Proliferation Studies (CNS), Monterey Institute of International Studies, July 2004

Sandschenider Eberhard. "Transatlantic Divergences on the Rise of China” p.24 in American and European relations with China: advancing common agendas, ed. David Shambaugh, Gudrin Wacker (Berlin: Stiftung Wissenshaft und Politik, German Institute for International and Security Affairs, 2008)

Seung Chong "Europeans keen to lift arms ban: Trade in defence technology has never been entirely closed”, The Financial Times, February 16, 2005

Shambaugh David “China and Europe: the Emerging Axis” Current History (2004)

Shambaugh David “Don't lift the arms embargo on China”, Brookings Institution, February 23, 2005

Shambaugh David. “China and Europe, The Emerging Axis”. Current History, September 2004

Sheehan Michael. International security, (Boulder, London: Lynne Rienner Publishers , 2005).

Shen Dingli. “Can sanctions stop proliferation?”, The Washington Quarterly, 31:3 (Summer 2008): 89-100

Schmidt Vivien. "Europeanization and the mechanics of economics policy adjustment". Journal of European Public Policy 9:6 (December 2002): 894-912, 909

Schulte-Kulkman Nicole “The German-Chinese 'Rule of Law Dialogue’:

Substantial Interaction or Political Delusion”, in German-Chinese Relations: Trade promotion or something else, ed. Overhaus Maro, Sebastian Harnish and Hans Marell, 
German Foreign Policy in Dialogue, Newsletter-Issue 16, Vol. 6, Trier, Germany, June 23, 2005, 36

Shulz Stefan "Foreign Policy: Aims, Instruments and Achievements”, European Parliament, Fact Sheets on the European Union., July 2008

http://www.europarl.europa.eu/parliament/expert/displayFtu.do?language=en\&id=74\&ftuId=FTU 6.1.1.html

Sipri Anthony. "Military relevant EU-China trade and technology transfers: issues and problem”. Paper presented at the Conference on Chinese Military Modernization: East Asian Political, Economic, and Defense Industrial Responses, organized by the Freeman Chair in China Studies and the Pacific Forum Center for Strategic and International Studies, Washington D.C.,

19-20 May 2005

Smith Craig. "In US visit, French envoy seeks support on arms issue” New York Times, March 29, 2005

Solana Javier. “A Secure Europe in a Better World: European Security Strategy”, Brussels, December 12, 2003

Spiegel Peter "US threat to UK defence groups over China arms: Pentagon decries European plans to lift embargo imposed after Tiananmen Square”, The Financial Times, 24/12/2004

Spiegel Online International The China Arms Embargo: "Sketching Out the Next TransAtlantic Crisis”, March 3, 2005, http://www.spiegel.de/international/0,1518,345333,00.html

Spiegel International Online "Schroeder Lonely at Home Over China Arms Ban” April 15, 2005 http://www.spiegel.de/international/0,1518,351503,00.html

Sonika Gupta, "EU and the Arms Embargo" Issue Brief Vol. 1 Issue. 1, Observer Research Foundation, 27 February 2004

Stumbaum May-Brit. The European Union and China. Decision-making in EU and Security Policy towards the People's Republic of China, DGAP-Schriften zur Internationalen Politik, (Baden-Baden: Nomos, 2009),

Tkacik John, "E.U. Leadership Finds Little Public Support for Lifting China Arms Ban”, Web Memo, Heritage Foundation, March 17, 2005

Taipei Central News Agency. "CNA: Germany Urged Not to Support Easing of Arms Sales Ban to China," 8 April 2004.

The Parliament.com “Berlin split over EU’s China arms embargo” April 14, 2005

Thornhill John and Daniel Dombey and Mark Huband "French minister defends plan to lift China arms embargo”, The Financial Times, April 6, 2005 
Tonra Ben. "The Europeanisation of national foreign policy : Dutch, Danish and Irish foreign policy in the European Union”, (Aldershot: Ashgate, 2001)

TTU Lettre Hebdomadaire d'Informations Stratégiques, «Europe-Chine : la panne », June 29, 2005

Umbach Frank "Will the EU Arms embargo towards PR China be lifted? Perspectives and implications” Taiwan Perspective e-paper, Issue no 29, (June 23, 2004)

Van Kemenade Willem. “ China-EU Issues: 2005-2010, Commonalities, Limitations, Potential” (prepared for XRG China: Developments \& Prospects 2005-2010 Report, European Institute for Asian Studies, Hong-Kong 2006),

Védrine Hubert, Former French Minister for Foreign Affairs, Interview by Vivien Exartier, Washington D.C., November 14, 2007.

Verification Research, Training and information Centre. "Verifying European Union arms embargoes". Paper submitted to the United Nations Institute for Disarmamanet Research (UNDIR) for the European Commission project on "European Action on Small Arms, Light Weapons and Explosive Remnants of War”, 18 april 2005

UK Ministry of Defense, Policy and Defense Relations, "Response to Questionnaire by Vivien Exartier”, August 6, 2008

USA Today on line. "EU fails to lift ban on arms sales to China"., April 14, 2005, http://www.usatoday.com/news/world/2005-04-15-eu-china_x.htm

Nicola Verola, “The New EU Foreign Policy under the Treaty of Lisbon” in The Foreign Policy of the European Union: Assessing Europe's Role in the World, ed. by Federiga Bindi, Washington D.C.: Brookings Institution Press 2010), 42

Volmer Karl . "German policy on Asia-Everything different after 11 September? -Speech by Minister of State Volmer, Berlin, Tuesday, 25 June 2002.

Watt Nicholas “EU could lift arms embargo on Chin”. The Guardian. 01/12/2005.

Weske Simon, “ The Role of France and Germany in EU-China Relations”, EU-China Studies Center Programme,(August 2007), 8

Williams Paul. "The Europeanization of British Foreign Policy and the Crisis in Zimbabwe”, paper presented at the European Foreign Policy Unit workshop on 'Europeanisation of national foreign policies' London School of Economics, 5 June 5, 2002

Williams Paul. “Who’s making UK foreign policy?” International Affairs 80, 5 (2004): 909919, 915 
Wolfe Adam. "France and Germany move to resume arms sales to China”, Power and Interest News Report (February 11, 2004).

Wong Ruben. The Europeanization of French policy: France and the EU in East Asia. (Basingstoke: Palgrave McMillan, 2006)

Wong Reuben. “Towards a Common European Policy on China.” Paper presented at the conference 'The European Union and the World: Asia, Enlargement and Constitutional Change', organized by IPSA Research Committee 3 on European Unification, in Beijing, 5-6 May 2005.

Xinhuanet News Agency "Brief Introduction to Relations between China and the UK", May 15, 2002, http://news.xinhuanet.com/english/2002-05/15/content_393213.htm

CURRICULUM VITAE

General Ph.D. in Political Science: Comparative Politics, Public Policy, International Relations, December 2010 
DISSERTATION: "The influence of Britain, France and Germany in the China EU policy: the case of the arms embargo.” Committee Chair: Dr. Donley Studlar

OKLAHOMA STATE UNIVERSITY, Stillwater, Oklahoma

Masters of Political Science, Major in International Relations 2006

THESIS: “The influence of Eastern European EU Member States in ESDP Operations”

ECOLE SUPERIEURE DE COMMERCE DE DIJON

(BURGUNDY BUSINESS SCHOOL), Dijon, France

Business Graduate Diploma 1999

French: native language, English: Fluent, Certificate of Proficiency of Cambridge University

German: written and spoken

PROFESSIONAL EXPERIENCE

WASHINGTON WORKSHOPS FOUNDATION, Washington, D.C., USA

Coordinator "Washington Internship Experience" and Director Operations, 2004-2009.

Run a congressional academic seminar for high school seminars: responsible for the marketing strategy, the placement of the candidates, the scheduling, the syllabus for an academic component, the budget and the students monitoringl; Increased enrollement through sales and marketing campaigns, expanded partnerships, upgraded the program.

Operations work for middle-school seminars and high-school seminars: field, scheduling, curriculum writing, staff assignment

\section{WEST VIRGINIA UNIVERSITY, Morgantown, West Virginia, USA}

Coordinator Office of Multicultural Programs-Student Life, Fall 2008 till present

Maintain existing multicultural programs, propose and develop new initiatives, enhance

understanding and appreciation of different cultures, outreach and engagement of students, staff, administrators and community

Programming to retain and educate the Freshmen population and Latino population. Develop

marketing plans, develop promotional material. Provide guidance and assistance to Latino population

\section{WEST VIRGINIA UNIVERSITY, Morgantown, West Virginia, USA}

Graduate Assistant, Center for Black Culture and Research, August 2004-May 2007

Assisted with Multicultural Programming. Auditing of multicultural needs on campus; organization of film series; organization of a forum on global warming; planning of cultural attachés embassies series; promotion of diversity among the University and the Morgantown communities.

2004 OUTSTANDING GRADUATE ASSISTANT AWARD Recipient 


\section{WEST VIRGINIA UNIVERSITY, Morgantown, West Virginia, USA}

Teaching Assistant, Political Science Department, Fall 2005.

Assisted Dr. Donley Studlar for the "Western Democracies" Political Science undergraduate course by teaching a couple of lectures on France, the European Union, contributed to other classes, prepared and graded exams.

\section{WOODROW WILSON INTERNATIONAL CENTER FOR SCHOLARS}

Research Assistant, June-August 2004

Performed research duties for Dr. Anne-Marie Le Gloannec, on the topic of the transatlantic relation in the field of foreign policy: failures, successes and prospects.

\section{WEST VIRGINIA UNIVERSITY, Morgantown, West Virginia, USA}

Research Assistant, Political Science Department. Fall 2002

Performed research duties for the Debate Varsity Team on Foreign Policy issues.

\section{OKLAHOMA STATE UNIVERSITY, Stillwater, Oklahoma, USA}

Teaching Assistant for the Political Science Department, 2001-2002

Assisted Dr. Jeff Lewis and Dr. Danny Atkison for the "American Government” Political Science freshman course class by monitoring, grading and recording exams, helping with instructional research. 2002 OUTSTANDING GRADUATE ASSISTANT AWARD Recipient

\section{UPWARD BOUND FEDERAL PROGRAM, OSU, Stillwater, Oklahoma, USA}

Graduate Assistant for the Office of Scholarships and Financial Aid, 2001-2002

In charge of the monthly workshops and summer programs during which low-income and first generation students complete a college preparatory program developing their personal, cultural, social, and aca.demic awareness.

\section{AMORA MAILLE (BESTFOODS, UNILEVER), Dijon, France}

-Assistant Area Manager UK/Eire, 1999

Commercial follow-up of local distributors: meeting orders, marketing, promotional, sales, logistics, R\&D demands, launch of products and market analysis.

-Assistant International Brand Manager

Follow-up of marketing projects for the Area Managers and the subsidiaries (launch and adaptation of products, promotions), coordinated the actions of various departments: $R \& D$, buying, production, sales; rationalization and optimization of export ranges, adaptation of domestic products for export.

\section{INVITED LECTURES AND TEACHING}

POLS 352: The Politics of the European Union Spring 2009 and 2010: “Global Policies: Trade and Aid, Foreign and Defense Policies”. Instructor: Dr. Donley Studlar, West Virginia University 
POLS 353: Western Democratic Governments Fall 2007, 2008 and 2009: "Major States and their interaction with the European Union: France”. Instructor: Dr. Donley Studlar, West Virginia University

HONRS 439: “Global Awareness”, Fall 2010. Instructor: Vivien Exartier

\section{CONFERENCES AND PAPERS}

Southern Political Association, 2010 Annual Conference, Atlanta, Georgia, Jan 7-10

Paper: "French response to Europeanization of EU China policy"

EUSA Eleventh Biennial International Conference, Marina del Rey, USA, April 23-April 25, 2009

Paper: The influence of Britain, Germany and France on EU China policy: the case of the lift of the arms embargo

EUSA Tenth Biennial International Conference, Montreal, Canada, May 17-May 19, 2007

Paper: "The security implications of the European Union Enlargement"

Young Leaders Forum, 2006 NATO Heads of State Summit, Riga, Latvia Nov 28-30

Representing France in discussions on the future of NATO

Model NATO 2006, Portoroz, Slovenia Sept 22-26, sponsored by NATO, MEF and IAPSS

Representing France in a simulation of the summit of the Ministers of Defense

Southern Political Association, 2006 Annual Conference, Atlanta, Georgia, Jan 4-7

Paper: "Europeanization and the impact on regional governance in the new Member States of the European Union”

Midwest Political Science Association, 2005 Annual Conference, Chicago, April 7-10

Paper: "Principal or Agent Theory applied to the European Union model of governance: the case of the Common Foreign Security Policy”

International Studies Association, 2005 Annual Convention, Honolulu, Hawaii, March 1-5, Poster: "The European Commission: Principal or Agent?”

ASSOCIATIONS MEMBERSHIP

EUSA (European Union Studies Association

Southern Political Science Association

Midwest Political Association

\section{TRAVELS}

Austria, Belgium, Czech Republic, Denmark, Germany, Italy, Latvia, People’s Republic of China, Slovenia, Switzerland, United Kingdom Denmark

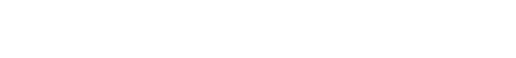
Virginia University Libraries,

Hagen $\quad \begin{aligned} & \text { ou=Acquisitions Department, } \\ & \text { email=John.Hagen@mail.wvu.edu }\end{aligned}$ 